\title{
Non-clinical interventions for reducing unnecessary caesarean section (Review)
}

Chen I, Opiyo N, Tavender E, Mortazhejri S, Rader T, Petkovic J, Yogasingam S, Taljaard M, Agarwal S, Laopaiboon M, Wasiak J, Khunpradit S, Lumbiganon P, Gruen RL, Betran AP

Chen I, Opiyo N, Tavender E, Mortazhejri S, Rader T, Petkovic J, Yogasingam S, Taljaard M, Agarwal S, Laopaiboon M, Wasiak J, Khunpradit S, Lumbiganon P, Gruen RL, Betran AP.

Non-clinical interventions for reducing unnecessary caesarean section.

Cochrane Database of Systematic Reviews 2018, Issue 9. Art. No.: CD005528.

DOI: 10.1002/14651858.CD005528.pub3.

www.cochranelibrary.com 
TABLE OF CONTENTS

HEADER 1

ABSTRACT

PLAIN LANGUAGE SUMMARY

SUMMARY OF FINDINGS

BACKGROUND

OBJECTIVES

METHODS

RESULTS

Figure 1.

Figure 2.

DISCUSSION

AUTHORS' CONCLUSIONS

ACKNOWLEDGEMENTS

REFERENCES

CHARACTERISTICS OF STUDIES

ADDITIONAL TABLES

APPENDICES

WHAT'S NEW

HISTORY

CONTRIBUTIONS OF AUTHORS

DECLARATIONS OF INTEREST

SOURCES OF SUPPORT

DIFFERENCES BETWEEN PROTOCOL AND REVIEW

INDEX TERMS

1

3

4

27

28

28

30

30

33

36

37

38

39

46

86

116

130

130

131

131

131

132

132 
[Intervention Review]

\section{Non-clinical interventions for reducing unnecessary caesarean section}

Innie Chen ${ }^{1}$, Newton Opiyo ${ }^{2}$, Emma Tavender ${ }^{3}$, Sameh Mortazhejri ${ }^{4}$, Tamara Rader ${ }^{5}$, Jennifer Petkovic ${ }^{6}$, Sharlini Yogasingam ${ }^{4}$, Monica Taljaard7, Sugandha Agarwal4, Malinee Laopaiboon8, Jason Wasiak9,10, Suthit Khunpradit11, Pisake Lumbiganon12, Russell L Gruen13, Ana Pilar Betran 14

1Department of Obstetrics \& Gynecology, University of Ottawa, Ottawa, Canada. ${ }^{2}$ Cochrane Editorial Unit, Cochrane, London, UK. ${ }_{3}$ Australian Satellite of the Cochrane EPOC Group, School of Public Health and Preventative Medicine, Monash University, Melbourne, Australia. ${ }^{4}$ Ottawa Hospital Research Institute, Ottawa, Canada. ${ }^{5}$ Canadian Agency for Drugs and Technologies in Health (CADTH), Ottawa, Canada. ${ }^{6}$ Bruyère Research Institute, University of Ottawa, Ottawa, Canada. ${ }^{7}$ Clinical Epidemiology Program, Ottawa Hospital Research Institute, Ottawa, Canada. ${ }^{8}$ Department of Epidemiology and Biostatistics, Faculty of Public Health, Khon Kaen University, Khon Kaen, Thailand. ${ }^{9}$ Olivia Newton John Cancer Research Institute; Department of Paediatrics, Austin Health; The University of Melbourne, Melbourne, Australia. ${ }^{10}$ Department of Pediatrics, University of Melbourne, Melbourne, Australia. ${ }^{11}$ Department of Obstetrics and Gynaecology, Lamphun Hospital, Lamphun, Thailand. 12Department of Obstetrics and Gynaecology, Faculty of Medicine, Khon Kaen University, Khon Kaen, Thailand. 13Lee Kong Chian School of Medicine, Nanyang Technological University, Singapore, Singapore. 14UNDP/UNFPA/UNICEF/WHO/World Bank Special Programme of Research, Development and Research Training in Human Reproduction, Department of Reproductive Health and Research, World Health Organization, Geneva, Switzerland

Contact address: Innie Chen, Department of Obstetrics \& Gynecology, University of Ottawa, Ottawa, ON, Canada. ichen@toh.on.ca.

Editorial group: Cochrane Effective Practice and Organisation of Care Group.

Publication status and date: New search for studies and content updated (conclusions changed), published in Issue 9, 2018.

Citation: Chen I, Opiyo N, Tavender E, Mortazhejri S, Rader T, Petkovic J, Yogasingam S, Taljaard M, Agarwal S, Laopaiboon M, Wasiak J, Khunpradit S, Lumbiganon P, Gruen RL, Betran AP. Non-clinical interventions for reducing unnecessary caesarean section. Cochrane Database of Systematic Reviews 2018, Issue 9. Art. No.: CD005528. DOI: 10.1002/14651858.CD005528.pub3.

Copyright @ 2018 The Cochrane Collaboration. Published by John Wiley \& Sons, Ltd.

\section{A B S T R A C T}

\section{Background}

Caesarean section rates are increasing globally. The factors contributing to this increase are complex, and identifying interventions to address them is challenging. Non-clinical interventions are applied independently of a clinical encounter between a health provider and a patient. Such interventions may target women, health professionals or organisations. They address the determinants of caesarean births and could have a role in reducing unnecessary caesarean sections. This review was first published in 2011. This review update will inform a new WHO guideline, and the scope of the update was informed by WHO's Guideline Development Group for this guideline.

\section{Objectives}

To evaluate the effectiveness and safety of non-clinical interventions intended to reduce unnecessary caesarean section.

\section{Search methods}

We searched CENTRAL, MEDLINE, Embase, CINAHL and two trials registers in March 2018. We also searched websites of relevant organisations and reference lists of related reviews.

\section{Selection criteria}

Randomised trials, non-randomised trials, controlled before-after studies, interrupted time series studies and repeated measures studies were eligible for inclusion. The primary outcome measures were: caesarean section, spontaneous vaginal birth and instrumental birth. 


\section{Data collection and analysis}

We followed standard methodological procedures recommended by Cochrane. We narratively described results of individual studies (drawing summarised evidence from single studies assessing distinct interventions).

\section{Main results}

We included 29 studies in this review (19 randomised trials, 1 controlled before-after study and 9 interrupted time series studies). Most of the studies (20 studies) were conducted in high-income countries and none took place in low-income countries. The studies enrolled a mixed population of pregnant women, including nulliparous women, multiparous women, women with a fear of childbirth, women with high levels of anxiety and women having undergone a previous caesarean section.

Overall, we found low-, moderate- or high-certainty evidence that the following interventions have a beneficial effect on at least one primary outcome measure and no moderate- or high-certainty evidence of adverse effects.

\section{Interventions targeted at women or families}

Childbirth training workshops for mothers alone may reduce caesarean section (risk ratio (RR) $0.55,95 \%$ confidence interval (Cl) 0.33 to 0.89 ) and may increase spontaneous vaginal birth (RR $2.25,95 \% \mathrm{Cl} 1.16$ to 4.36 ). Childbirth training workshops for couples may reduce caesarean section ( $\mathrm{RR} 0.59,95 \% \mathrm{Cl} 0.37$ to 0.94 ) and may increase spontaneous vaginal birth ( $\mathrm{RR} 2.13,95 \% \mathrm{Cl} 1.09$ to 4.16 ). We judged this one study with 60 participants to have low-certainty evidence for the outcomes above.

Nurse-led applied relaxation training programmes (RR $0.22,95 \% \mathrm{Cl} 0.11$ to $0.43 ; 104$ participants, low-certainty evidence) and psychosocial couple-based prevention programmes (RR $0.53,95 \% \mathrm{Cl} 0.32$ to $0.90 ; 147$ participants, low-certainty evidence) may reduce caesarean section. Psychoeducation may increase spontaneous vaginal birth (RR 1.33, 95\% Cl 1.11 to 1.61; 371 participants, low-certainty evidence). The control group received routine maternity care in all studies.

There were insufficient data on the effect of the four interventions on maternal and neonatal mortality or morbidity.

\section{Interventions targeted at healthcare professionals}

Implementation of clinical practice guidelines combined with mandatory second opinion for caesarean section indication slightly reduces the risk of overall caesarean section (mean difference in rate change $-1.9 \%, 95 \% \mathrm{Cl}-3.8$ to $-0.1 ; 149,223$ participants). Implementation of clinical practice guidelines combined with audit and feedback also slightly reduces the risk of caesarean section (risk difference (RD) $-1.8 \%, 95 \% \mathrm{Cl}-3.8$ to $-0.2 ; 105,351$ participants). Physician education by local opinion leader (obstetrician-gynaecologist) reduced the risk of elective caesarean section to $53.7 \%$ from $66.8 \%$ (opinion leader education: $53.7 \%, 95 \% \mathrm{Cl} 46.5$ to $61.0 \%$; control: $66.8 \%, 95 \% \mathrm{Cl} 61.7$ to $72.0 \%$; 2496 participants). Healthcare professionals in the control groups received routine care in the studies. There was little or no difference in maternal and neonatal mortality or morbidity between study groups. We judged the certainty of evidence to be high.

\section{Interventions targeted at healthcare organisations or facilities}

Collaborative midwifery-labourist care (in which the obstetrician provides in-house labour and delivery coverage, 24 hours a day, without competing clinical duties), versus a private practice model of care, may reduce the primary caesarean section rate. In one interrupted time series study, the caesarean section rate decreased by $7 \%$ in the year after the intervention, and by $1.7 \%$ per year thereafter $(1722$ participants); the vaginal birth rate after caesarean section increased from $13.3 \%$ before to $22.4 \%$ after the intervention (684 participants). Maternal and neonatal mortality were not reported. We judged the certainty of evidence to be low.

We studied the following interventions, and they either made little or no difference to caesarean section rates or had uncertain effects.

Moderate-certainty evidence suggests little or no difference in caesarean section rates between usual care and: antenatal education programmes for physiologic childbirth; antenatal education on natural childbirth preparation with training in breathing and relaxation techniques; computer-based decision aids; individualised prenatal education and support programmes (versus written information in pamphlet).

Low-certainty evidence suggests little or no difference in caesarean section rates between usual care and: psychoeducation; pelvic floor muscle training exercises with telephone follow-up (versus pelvic floor muscle training without telephone follow-up); intensive group therapy (cognitive behavioural therapy and childbirth psychotherapy); education of public health nurses on childbirth classes; role play (versus standard education using lectures); interactive decision aids (versus educational brochures); labourist model of obstetric care (versus traditional model of obstetric care).

We are very uncertain as to the effect of other interventions identified on caesarean section rates as the certainty of the evidence is very low.

\section{Authors' conclusions}

We evaluated a wide range of non-clinical interventions to reduce unnecessary caesarean section, mostly in high-income settings. Few interventions with moderate- or high-certainty evidence, mainly targeting healthcare professionals (implementation of guidelines 
combined with mandatory second opinion, implementation of guidelines combined with audit and feedback, physician education by local opinion leader) have been shown to safely reduce caesarean section rates. There are uncertainties in existing evidence related to verylow or low-certainty evidence, applicability of interventions and lack of studies, particularly around interventions targeted at women or families and healthcare organisations or facilities.

\section{PLAIN LANGUAGE SUMMARY}

\section{Non-clinical interventions for reducing unnecessary caesarean section}

\section{What is the aim of this review?}

The aim of this Cochrane Review was to find out whether non-clinical interventions, which aim to reduce unnecessary caesarean sections, such as providing education to healthcare workers and mothers, are safe and effective. This review was first published in 2011 . This review update will inform a new WHO guideline, and the scope of the update was informed by WHO's Guideline Development Group for this guideline.

\section{Key messages}

We studied a wide range of non-clinical interventions that aim to reduce unnecessary caesarean sections, mostly in high-income countries. Based on high-quality evidence, few interventions have been shown to reduce caesarean section rates without adverse effects on maternal or neonatal outcomes. These interventions are mainly aimed at healthcare professionals (nurses, midwives, physicians) and involve using: clinical guidelines combined with mandatory second opinion for caesarean section indication; clinical guidelines combined with audit and feedback about caesarean section practices; and opinion leaders (obstetrician/gynaecologist) to provide education to healthcare professionals.

\section{What was studied in this review?}

Caesarean section is an operation used to prevent and reduce complications of childbirth. While it can be a life-saving procedure for both the mother and baby, caesarean section is not without harm and should only be carried out when necessary. Caesarean sections increase the likelihood of bleeding, maternal infections and infant breathing problems, among other complications. The number of caesarean sections performed has been increasing worldwide. Whilst there may be medical reasons for this increase, other factors, such as clinician convenience and maternal fears, may also be responsible.

\section{What are the main results of the review?}

We included 29 studies in this review. Most of the studies (20 studies) were conducted in high-income countries; none in low-income countries.

We rated the quality of the evidence from studies using four levels: very low, low, moderate, or high. Very low-quality means that we are very uncertain about the results. High-quality evidence means that we are very confident in the results.

Overall, we found eight of the 29 interventions included in the review to have a beneficial effect on at least one of our main outcomes with low-, moderate- or high-quality evidence, and no moderate- or high-quality evidence of harm:

Interventions aimed at women or families: providing childbirth training workshops for mothers and couples; relaxation training programmes led by nurses; psychosocial couple-based prevention programmes; and psychoeducation. The interventions were compared to routine practice. The quality of evidence from the studies was low.

Interventions aimed at healthcare professionals: using clinical guidelines combined with mandatory second opinion for caesarean section indication; using clinical guidelines combined with audit and feedback about caesarean section practices; and having opinion leaders (obstetrician/gynaecologist) provide education to healthcare professionals. The interventions were compared to routine practice. The quality of evidence was high.

Interventions aimed at healthcare organisations or facilities: collaborative midwifery-labourist model of care (in which the obstetrician provides in-house labour and delivery coverage, 24 hours a day, without competing clinical duties) compared to a private model of care. The quality of evidence was low.

We studied a number of other interventions and they either made little or no difference to caesarean section rates, or had uncertain effects.

Limited data were available on possible harms associated with the interventions examined in this review.

\section{How up-to-date is this review?}

The evidence is current to March 2018. 


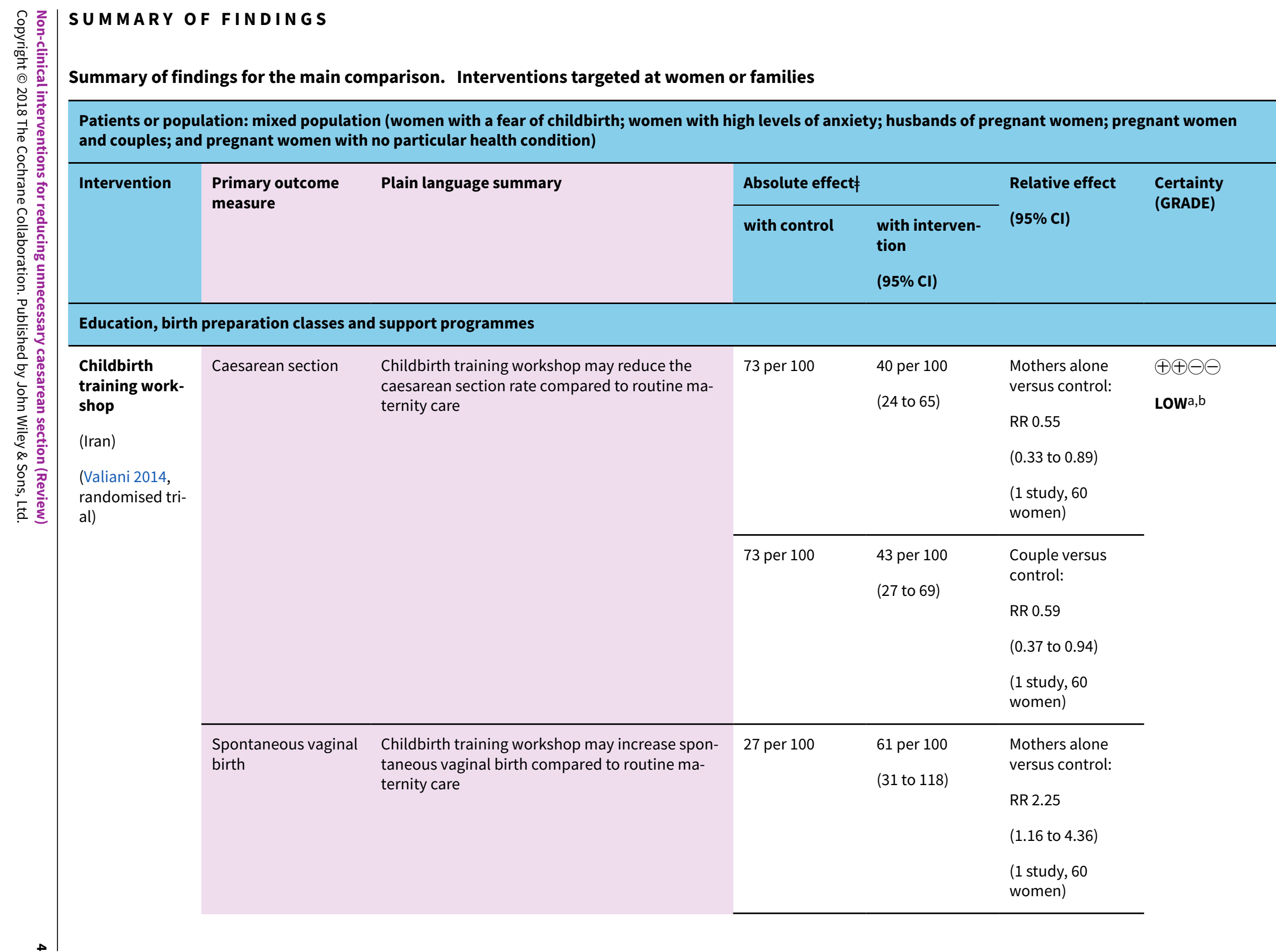




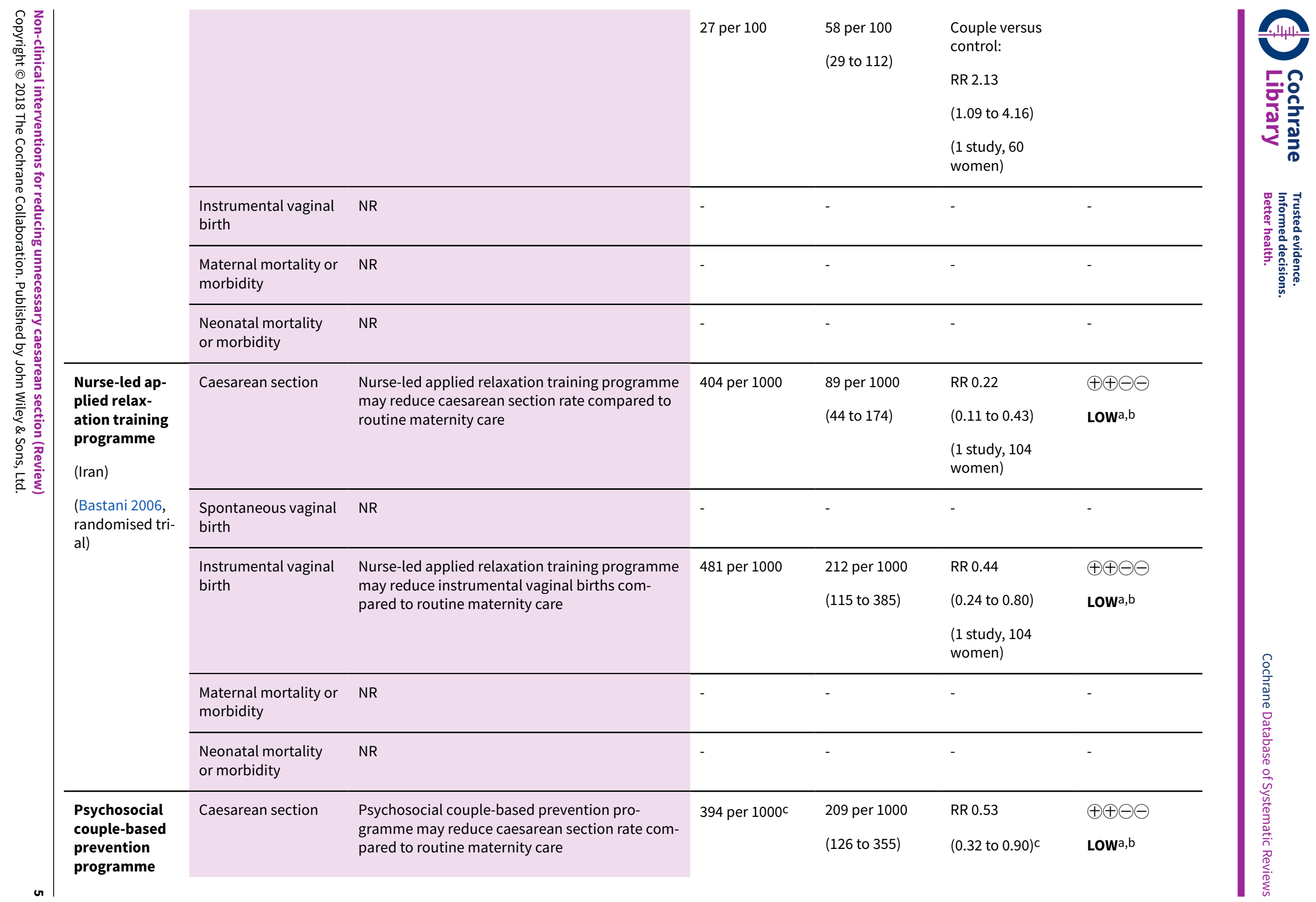




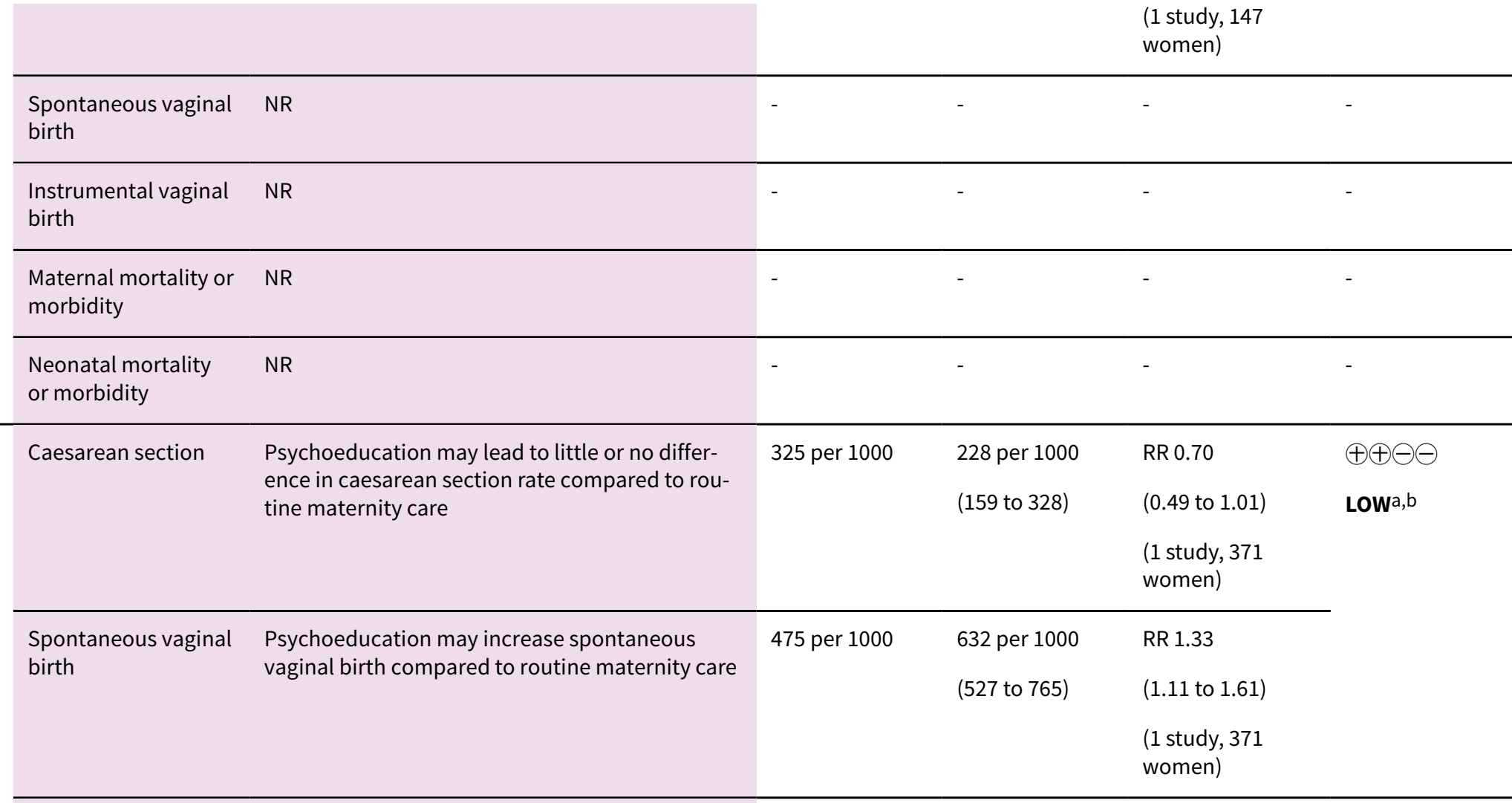

\section{Psychoeduca}

tion

(Finland)

(Rouhe 2013,

randomised tri-

al)

\section{Instrumental vaginal NR}

birth

Maternal mortality or NR

morbidity

Neonatal mortality NR

or morbidity

Antenatal ed- Caesarean section Antenatal education programme for physiolog-

ucation pro- $\quad$ ic childbirth probably leads to little or no differ-

gramme for

ence in caesarean section rate compared to rou-

437 per 1000

tine maternity care

$\begin{array}{ll}450 \text { per } 1000 & \text { RR } 1.03 \\ \text { (315 to 651) } & \text { (0.72 to } 1.49) \\ & \begin{array}{l}\text { (1 study, } 150 \\ \text { women) }\end{array}\end{array}$

$\oplus \oplus \oplus \ominus$

physiologic

women) 


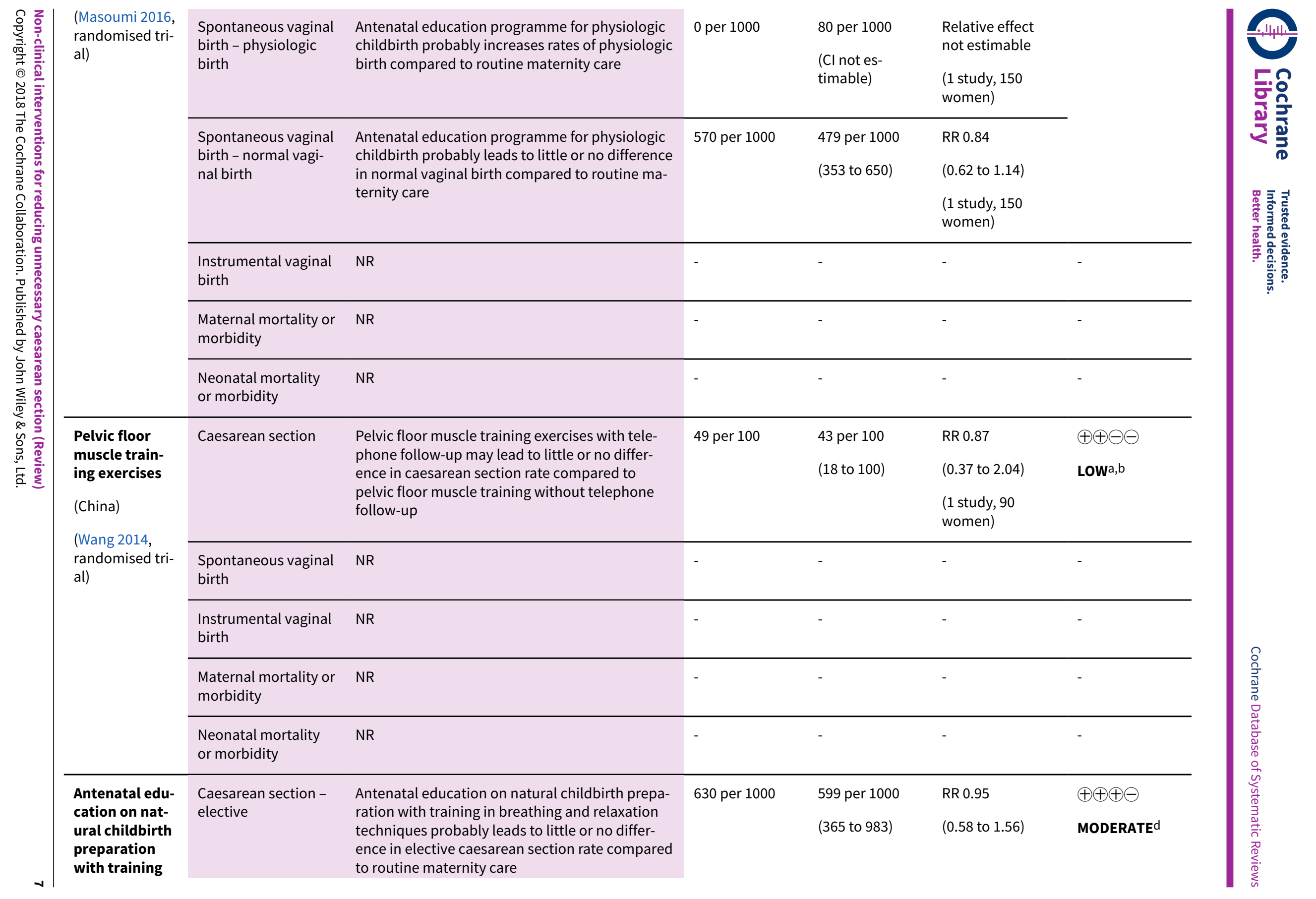


in breathing

and relaxation

techniques

(Sweden)

(Bergstrom

2009, ran-

domised trial)

birth

pontaneous vaginal

Caesarean section -

emergency

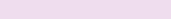

ence in spontaneous vaginal birth rate compared to routine maternity care

Instrumental vaginal Antenatal education on natural childbirth prepa-

birth ration with training in breathing and relaxation

techniques probably leads to little or no differ-

ence in instrumental vaginal birth rate compared

to routine maternity care

ence inues probably leads to little or no differ-
1 study, 977

women)

RR 0.91

(102 to 187$)$

$(0.67$ to 1.23$)$

(1 study, 977

women

663 per $1000 \quad 663$ per $1000 \quad$ RR 1.00

(603 to 723$) \quad(0.91$ to 1.09$)$

(1 study, 977

women)

122 per $1000 \quad 139$ per $1000 \quad$ RR 1.14

(100 to 192$)$

(0.82 to 1.57 )

(1 study, 977

women

Maternal mortality or NR

morbidity

\begin{tabular}{|c|c|c|c|c|}
\hline $\begin{array}{l}\text { Neonatal mortality } \\
\text { or morbidity }\end{array}$ & NR & - & - & - \\
\hline $\begin{array}{l}\text { Caesarean section - } \\
\text { elective }\end{array}$ & $\begin{array}{l}\text { Information group versus usual care: comput- } \\
\text { er-based decision aids (information programme) } \\
\text { probably leads to little or no difference in elec- } \\
\text { tive caesarean section rate compared to usual } \\
\text { care }\end{array}$ & 496 per 1000 & $\begin{array}{l}486 \text { per } 1000 \\
(407 \text { to } 585)\end{array}$ & $\begin{array}{l}\text { RR } 0.98 \\
\text { (0.82 to } 1.18) \\
\text { (1 study, } 478 \\
\text { women) }\end{array}$ \\
\hline $\begin{array}{l}\text { Caesarean section - } \\
\text { elective }\end{array}$ & $\begin{array}{l}\text { Decision analysis group versus usual care: } \\
\text { computer-based decision aids (decision analysis) } \\
\text { probably leads to little or no difference in elec- } \\
\text { tive caesarean section rate compared to usual } \\
\text { care }\end{array}$ & 496 per 1000 & $\begin{array}{l}412 \text { per } 1000 \\
\text { (337 to } 506 \text { ) }\end{array}$ & $\begin{array}{l}\text { RR } 0.83 \\
\text { (0.68 to } 1.02 \text { ) } \\
\text { (1 study, } 478 \\
\text { women) }\end{array}$ \\
\hline $\begin{array}{l}\text { Caesarean section - } \\
\text { emergency }\end{array}$ & $\begin{array}{l}\text { Information group versus usual care: comput- } \\
\text { er-based decision aids (information programme) } \\
\text { probably leads to little or no difference in emer- }\end{array}$ & 202 per 1000 & $\begin{array}{l}220 \text { per } 1000 \\
(156 \text { to } 313)\end{array}$ & $\begin{array}{l}\text { RR } 1.09 \\
\text { (0.77 to } 1.55)\end{array}$ \\
\hline
\end{tabular}

$\oplus \oplus \oplus \ominus$

Comput-

er-based deci-

sion aids (in-

ormation pro-

gramme, deci-

sion analysis)

(UK)

(Montgomery

2007, ran-

domised trial)

(156 to 313 )

MODERATE 


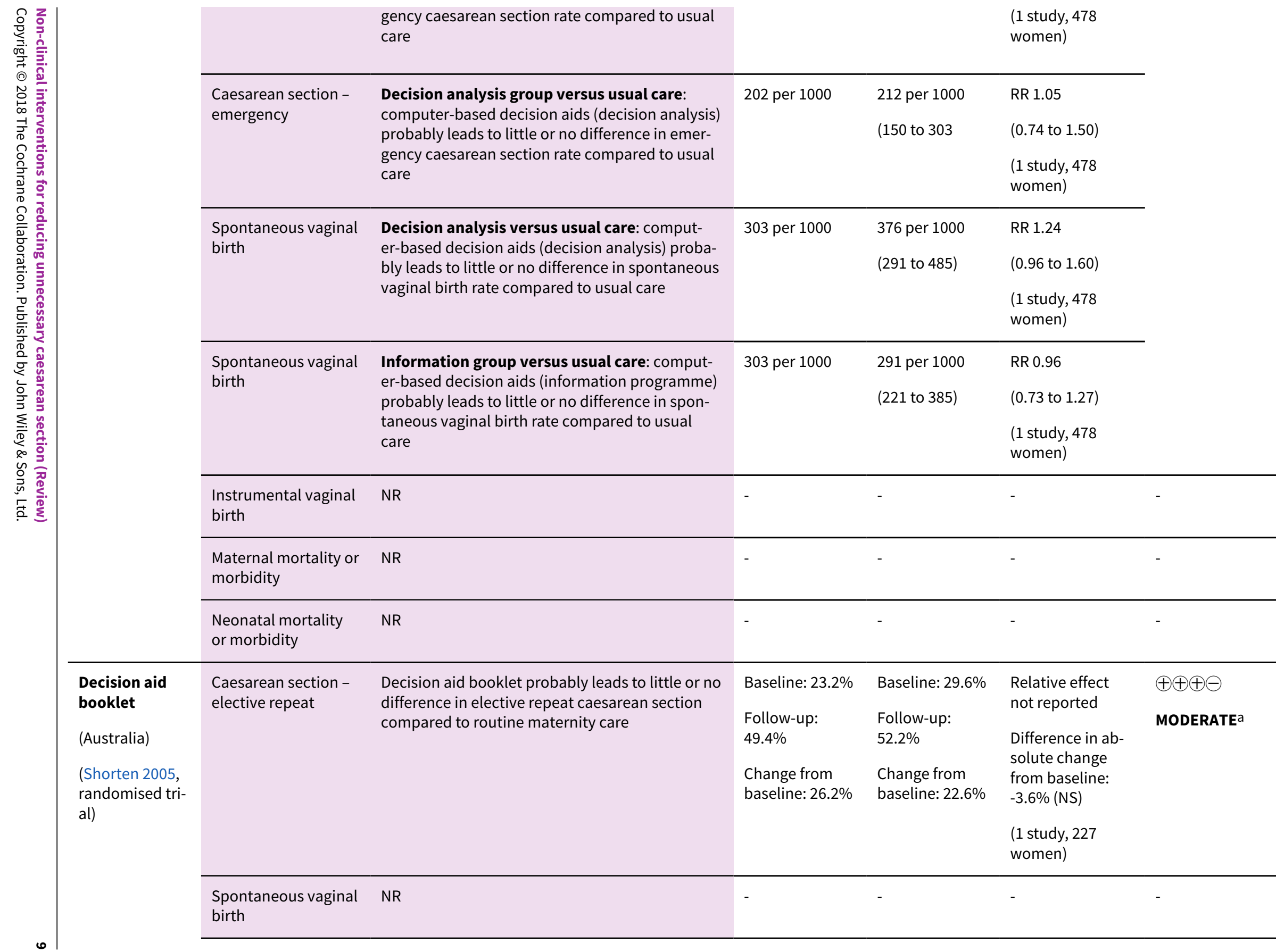


birth

Maternal mortality or NR

morbidity

Neonatal mortality NR

or morbidity

Intensive

Caesarean section Intensive group therapy (cognitive behavioural therapy and childbirth psychotherapy) may lead

to little or no difference in caesarean section rate

484 per 1000

436 per 1000

RR 0.90

$\oplus \oplus \ominus \ominus$

py (cognitive

behavioural

therapy and

compared to routine maternity care

(315 to 600$) \quad$ (0.65 to 1.24$)$

Lowa,b

childbirth psy-

chotherapy)

(Finland)

(Saisto 2001,

randomised tri-

al)

Caesarean section
- for psychological

Intensive group therapy (cognitive behavioural

therapy and childbirth psychotherapy) may lead

reasons

to little or no difference in caesarean section rate

(1 study, 176

women)

for psychological reasons compared to routine

maternity care

286 per $1000 \quad 235$ per $1000 \quad$ RR 0.82

(143 to 389$)$

(0.50 to 1.36$)$

Spontaneous vaginal NR

birth

Instrumental vaginal NR

birth

Maternal mortality or NR

morbidity

Neonatal mortality $\quad$ NR

or morbidity

Psychoeduca-

tion sessions

by telephone

Caesarean section - The effect of psychoeducation sessions by tele-

overall

phone (compared to routine maternity care) on

overall caesarean section rate is uncertain

419 per 1000

339 per 1000

RR 0.81

$\oplus \Theta \Theta \Theta$

(Australia)

(Fenwick 2015, randomised trial)

\section{Caesarean section - \\ The effect of psychoeducation sessions by tele- phone (compared to routine maternity care) on emergency caesarean section rate is uncertain}

(235 to 494$)$

(0.56 to 1.18$)$

VERY LOWa,b,

$\begin{array}{lll} & & \\ 247 \text { per } 1000 & \text { 173 per } 1000 & \text { RR } 0.70 \\ & \text { (96 to 304) } & \text { (0.39 to } 1.23)\end{array}$




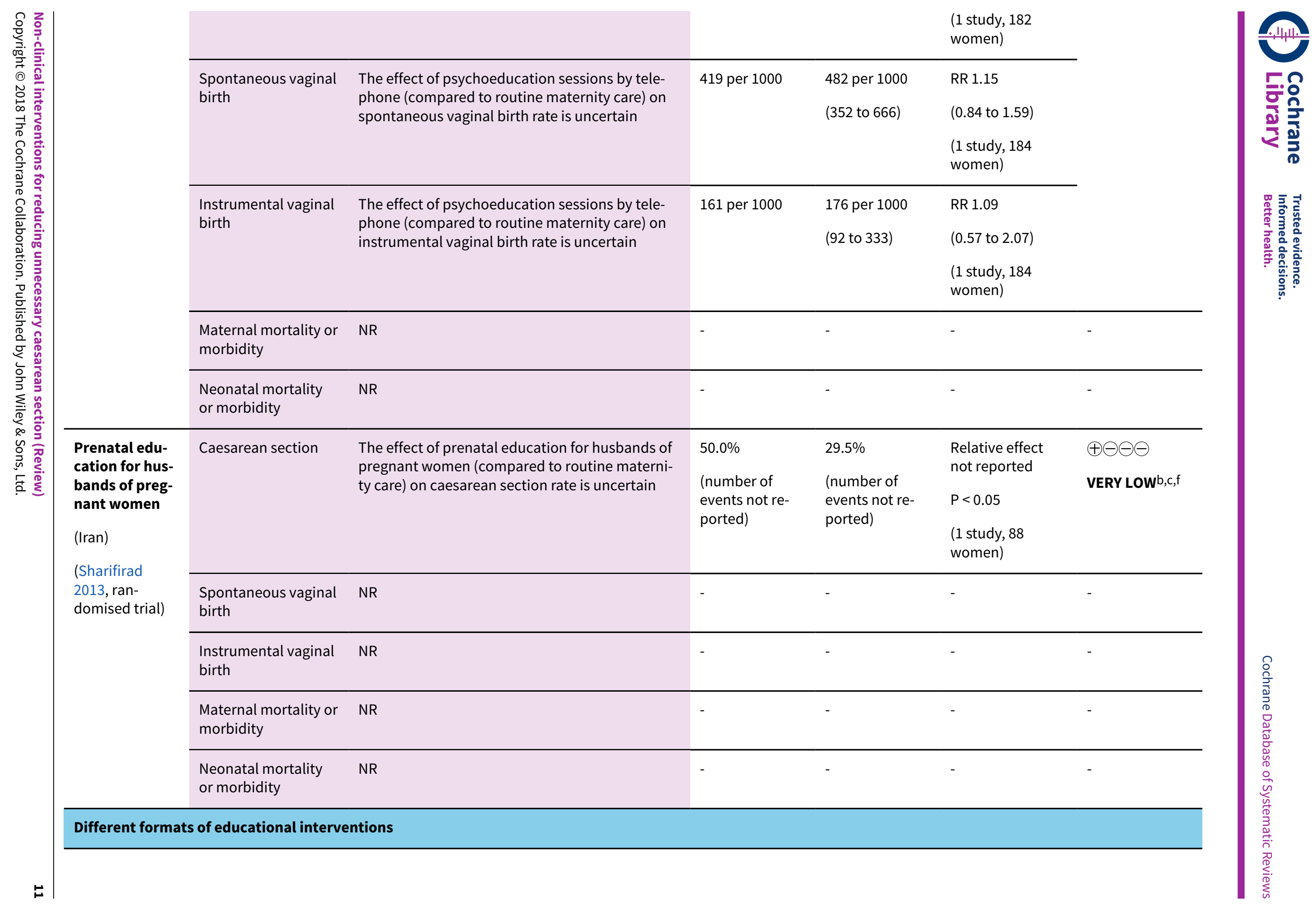




\begin{tabular}{|c|c|c|c|c|c|c|c|c|}
\hline 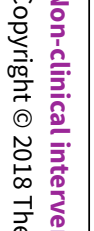 & $\begin{array}{l}\text { Role play ver- } \\
\text { sus standard } \\
\text { education us- } \\
\text { ing lectures } \\
\text { (Iran) }\end{array}$ & Caesarean section & $\begin{array}{l}\text { Role play may lead to little or no difference in } \\
\text { caesarean section rate compared to education } \\
\text { using lectures }\end{array}$ & 56 per 100 & $\begin{array}{l}37 \text { per } 100 \\
(22 \text { to } 63 \text { ) }\end{array}$ & $\begin{array}{l}\text { RR } 0.66 \\
\text { (0.39 to } 1.12 \text { ) } \\
\text { (1 study, } 67 \\
\text { women) }\end{array}$ & $\begin{array}{l}\oplus \oplus \ominus \ominus \\
\text { Lowa,b }\end{array}$ & 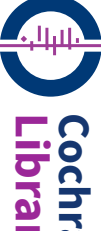 \\
\hline 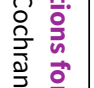 & $\begin{array}{l}\text { (Navaee } 2015, \\
\text { randomised tri- }\end{array}$ & $\begin{array}{l}\text { Spontaneous vaginal } \\
\text { birth }\end{array}$ & NR & - & - & - & - & D \\
\hline 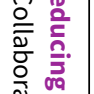 & & $\begin{array}{l}\text { Instrumental vaginal } \\
\text { birth }\end{array}$ & NR & - & - & - & - & 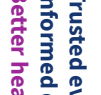 \\
\hline 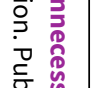 & & $\begin{array}{l}\text { Maternal mortality or } \\
\text { morbidity }\end{array}$ & NR & - & - & - & - & \\
\hline 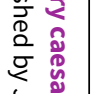 & & $\begin{array}{l}\text { Neonatal mortality } \\
\text { or morbidity }\end{array}$ & NR & - & - & - & - & \\
\hline 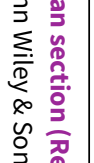 & $\begin{array}{l}\text { Interactive de- } \\
\text { cision aid ver- } \\
\text { sus education- } \\
\text { al brochures }\end{array}$ & $\begin{array}{l}\text { Caesarean section - } \\
\text { VBAC }\end{array}$ & $\begin{array}{l}\text { Interactive decision aid may lead to little or no } \\
\text { difference in VBAC rate compared to educational } \\
\text { brochures }\end{array}$ & $\begin{array}{l}37 \% \\
\text { Number of } \\
\text { events unclear }\end{array}$ & $\begin{array}{l}41 \% \\
\text { Number of } \\
\text { events unclear }\end{array}$ & $\begin{array}{l}P=0.72 \\
\text { Number of partic- } \\
\text { ipants unclear }\end{array}$ & $\begin{array}{l}\oplus \oplus \Theta \Theta \\
\text { Lowa,b }\end{array}$ & \\
\hline हैं & (USA) & $\begin{array}{l}\text { Spontaneous vaginal } \\
\text { birth }\end{array}$ & NR & - & - & - & - & \\
\hline & $\begin{array}{l}\text { randomised tri- } \\
\text { al) }\end{array}$ & $\begin{array}{l}\text { Instrumental vaginal } \\
\text { birth }\end{array}$ & NR & - & - & - & - & \\
\hline & & $\begin{array}{l}\text { Maternal mortality or } \\
\text { morbidity }\end{array}$ & NR & - & - & - & - & \\
\hline & & $\begin{array}{l}\text { Neonatal mortality } \\
\text { or morbidity }\end{array}$ & NR & - & - & - & - & $\overbrace{\grave{n}}$ \\
\hline & $\begin{array}{l}\text { Individualised } \\
\text { prenatal ed- } \\
\text { ucation and } \\
\text { support pro- } \\
\text { gramme ver- } \\
\text { sus written in- }\end{array}$ & $\begin{array}{l}\text { Caesarean section - } \\
\text { scheduled }\end{array}$ & $\begin{array}{l}\text { Individualised prenatal education and support } \\
\text { programme probably leads to little or no differ- } \\
\text { ence in scheduled caesarean section rate com- } \\
\text { pared to written information in pamphlet }\end{array}$ & 237 per 1000 & $\begin{array}{l}213 \text { per } 1000 \\
\text { (175 to } 263 \text { ) }\end{array}$ & $\begin{array}{l}\text { RR } 0.90 \\
\text { (0.74 to } 1.11 \text { ) } \\
\text { (1 study, } 1275 \\
\text { women) }\end{array}$ & $\begin{array}{l}\oplus \oplus \oplus \ominus \\
\text { MODERATEa }\end{array}$ & 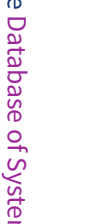 \\
\hline & $\begin{array}{l}\text { pamphlet } \\
\text { (Canada, USA) }\end{array}$ & $\begin{array}{l}\text { Caesarean section - } \\
\text { urgent }\end{array}$ & $\begin{array}{l}\text { Individualised prenatal education and support } \\
\text { programme probably leads to little or no differ- }\end{array}$ & 690 per 1000 & $\begin{array}{l}607 \text { per } 1000 \\
\text { (400 to } 918 \text { ) }\end{array}$ & $\begin{array}{l}\text { RR } 0.88 \\
\text { (0.58 to } 1.33 \text { ) }\end{array}$ & & 竞. \\
\hline
\end{tabular}


(Fraser 1997, randomised trial)

\begin{tabular}{|c|c|c|c|c|c|}
\hline & $\begin{array}{l}\text { ence in urgent caesarean section rate compared } \\
\text { to written information in pamphlet }\end{array}$ & & & $\begin{array}{l}\text { (1 study, } 1275 \\
\text { women) }\end{array}$ & \\
\hline $\begin{array}{l}\text { Caesarean section - } \\
\text { VBAC }\end{array}$ & $\begin{array}{l}\text { Individualised prenatal education and support } \\
\text { programme probably leads to little or no differ- } \\
\text { ence in VBAC rate compared to written informa- } \\
\text { tion in pamphlet }\end{array}$ & 490 per 1000 & $\begin{array}{l}529 \text { per } 1000 \\
(475 \text { to } 593)\end{array}$ & $\begin{array}{l}\text { RR } 1.08 \\
\text { (0.97 to } 1.21 \text { ) } \\
\text { (1 study, } 1275 \\
\text { women) }\end{array}$ & \\
\hline $\begin{array}{l}\text { Instrumental vaginal } \\
\text { birth }\end{array}$ & NR & - & - & - & - \\
\hline $\begin{array}{l}\text { Spontaneous vaginal } \\
\text { birth }\end{array}$ & NR & - & - & - & - \\
\hline Maternal mortality & NR & - & - & - & - \\
\hline $\begin{array}{l}\text { Maternal morbidity, } \\
\text { neonatal morbidity } \\
\text { or mortality }\end{array}$ & $\begin{array}{l}\text { Individualised prenatal education and support } \\
\text { programme probably leads to little or no differ- } \\
\text { ence in maternal morbidity, neonatal morbidity } \\
\text { or mortality compared to written information in } \\
\text { pamphlet }\end{array}$ & \multicolumn{3}{|c|}{$\begin{array}{l}\text { Rates of maternal morbidity and neonatal outcomes } \\
\text { were similar in the study groups (maternal-uterine rup- } \\
\text { ture or dehiscence, hysterectomy, blood transfusion; } \\
\text { neonatal-perinatal deaths, Apgar score less than } 7 \text { at } 5 \\
\text { minutes, admission to NICU) }\end{array}$} & $\begin{array}{l}\oplus \oplus \oplus \ominus \\
\text { MODERATEa }\end{array}$ \\
\hline
\end{tabular}

†The corresponding risk (absolute effect with intervention) (and its $95 \%$ confidence interval) is based on the assumed risk in the comparison group ((i.e. risk with control) and the relative effect of the intervention (and its $95 \% \mathrm{Cl}$ ).

About the certainty of the evidence (GRADE)*

High: this research provides a very good indication of the likely effect; the likelihood that the effect will be substantially different ${ }^{\dagger}$ is low.

Moderate: this research provides a good indication of the likely effect; the likelihood that the effect will be substantially different ${ }^{\dagger}$ is moderate.

Low: this research provides some indication of the likely effect; however, the likelihood that it will be substantially different ${ }^{\dagger}$ is high

Very low: this research does not provide a reliable indication of the likely effect; the likelihood that the effect will be substantially different ${ }^{\dagger}$ is very high

*This is sometimes referred to as 'quality of evidence' or 'confidence in the estimate'

†Substantially different $=$ a large enough difference that it might affect a decision

CI: confidence interval; NICU: neonatal intensive care unit; NR: not reported; NS; not significant; RR: risk ratio; VBAC: vaginal birth after caesarean.

aDowngraded one level for serious risk of bias (due to inadequate randomisation processes).

bDowngraded one level for serious imprecision (due to small sample size and few events).

CReanalysed, based on: control event rate $(40 \%, \mathrm{n}=71)$; intervention event rate $(21 \%, \mathrm{n}=76)$; odds ratio (OR) $0.36,95 \% \mathrm{Cl} 0.15$ to 0.86$)$. 


\begin{tabular}{|c|c|c|c|c|c|c|}
\hline \multicolumn{7}{|c|}{$\begin{array}{l}\text { eDowngraded one level for serious indirectness (follow-up analyses, not described in the trial report, indicated that the in } \\
\text { birth complications arising from foetal position (e.g. breech birth) and labour progression). } \\
\text { fDowngraded two levels for very serious risk of bias (due to inadequate randomisation processes and reporting issues). }\end{array}$} \\
\hline \multicolumn{7}{|c|}{ Summary of findings 2 . Interventions targeted at healthcare professionals } \\
\hline \multicolumn{7}{|c|}{ Patients or population: nurses, midwives, physicians } \\
\hline \multirow[t]{2}{*}{ Intervention } & \multirow{2}{*}{$\begin{array}{l}\text { Primary out- } \\
\text { come measure }\end{array}$} & \multirow[t]{2}{*}{ Plain language summary } & \multicolumn{2}{|l|}{ Absolute effect $\neq$} & \multirow{2}{*}{$\begin{array}{l}\text { Relative effect } \\
(95 \% \mathrm{CI})\end{array}$} & \multirow{2}{*}{$\begin{array}{l}\text { Certainty } \\
\text { (GRADE) }\end{array}$} \\
\hline & & & with control & $\begin{array}{l}\text { with intervention } \\
(95 \% \mathrm{Cl})\end{array}$ & & \\
\hline \multirow{3}{*}{$\begin{array}{l}\text { Implementa- } \\
\text { tion of clinical } \\
\text { practice guide- } \\
\text { lines combined } \\
\text { with manda- } \\
\text { tory second } \\
\text { opinion } \\
\text { (Argentina, } \\
\text { Brazil, Cuba, } \\
\text { Guatemala and } \\
\text { Mexico) } \\
\text { (Althabe 2004, } \\
\text { cluster-ran- } \\
\text { domised trial) }\end{array}$} & $\begin{array}{l}\text { Caesarean sec- } \\
\text { tion - all }\end{array}$ & $\begin{array}{l}\text { Implementation of clinical practice guidelines } \\
\text { combined with mandatory second opinion for } \\
\text { caesarean section indication slightly reduces } \\
\text { the caesarean section rate compared to routine } \\
\text { maternity care }\end{array}$ & $\begin{array}{l}\text { Mean baseline } \\
\text { rate: } 24.6(39,175 \\
\text { women) } \\
\text { Mean follow-up } \\
\text { rate: } 24.9(39,638 \\
\text { women) } \\
\text { Mean rate change: } \\
0.3\end{array}$ & $\begin{array}{l}\text { Mean baseline rate: } \\
26.3 \text { ( } 34,735 \text { women) } \\
\text { Mean follow-up rate: } \\
24.7 \text { (35,675 women) } \\
\text { Mean rate change: } \\
-1.6\end{array}$ & $\begin{array}{l}\text { Mean difference } \\
\text { in rate change: } \\
-1.9(-3.8 \text { to }-0.1)\end{array}$ & $\begin{array}{l}\oplus \oplus \oplus \oplus \\
\text { HIGH }\end{array}$ \\
\hline & $\begin{array}{l}\text { Caesarean sec- } \\
\text { tion - elective }\end{array}$ & $\begin{array}{l}\text { Implementation of clinical practice guidelines } \\
\text { combined with mandatory second opinion for } \\
\text { caesarean section indication results in little or } \\
\text { no difference in elective caesarean section rate } \\
\text { compared to routine maternity care }\end{array}$ & $\begin{array}{l}\text { Mean baseline rate: } \\
9.1 \text { ( } 39,175 \text { women) } \\
\text { Mean follow-up } \\
\text { rate: } 9.0 \text { ( } 39,638 \\
\text { women) } \\
\text { Mean rate change: } \\
-0.1\end{array}$ & $\begin{array}{l}\text { Mean baseline rate: } \\
8.9 \text { ( } 34,735 \text { women) } \\
\text { Mean follow-up rate: } \\
9.1 \text { ( } 35,675 \text { women) } \\
\text { Mean rate change: } \\
0.1\end{array}$ & $\begin{array}{l}\text { Mean difference } \\
\text { in rate change: } \\
0.2(-1.4 \text { to } 1.8)\end{array}$ & \\
\hline & $\begin{array}{l}\text { Caesarean sec- } \\
\text { tion - intra- } \\
\text { partum }\end{array}$ & $\begin{array}{l}\text { Implementation of clinical practice guidelines } \\
\text { combined with mandatory second opinion for } \\
\text { caesarean section indication slightly reduces } \\
\text { intrapartum caesarean section compared to } \\
\text { routine maternity care }\end{array}$ & $\begin{array}{l}\text { Mean baseline } \\
\text { rate: } 15.4 \text { ( } 39,175 \\
\text { women) } \\
\text { Mean follow-up } \\
\text { rate: } 15.9(39,638 \\
\text { women) }\end{array}$ & $\begin{array}{l}\text { Mean baseline rate: } \\
17.4 \text { ( } 34,735 \text { women) } \\
\text { Mean follow-up rate: } \\
15.6 \text { ( } 35,675 \text { women) } \\
\text { Mean rate change: } \\
-1.8\end{array}$ & $\begin{array}{l}\text { Mean difference } \\
\text { in rate change: } \\
-2.2(-4.3 \text { to }-0.1)\end{array}$ & \\
\hline
\end{tabular}




\begin{tabular}{|c|c|c|c|c|c|}
\hline & & $\begin{array}{l}\text { Mean rate change: } \\
0.4\end{array}$ & & & \\
\hline $\begin{array}{l}\text { Spontaneous } \\
\text { vaginal birth }\end{array}$ & NR & - & - & - & - \\
\hline $\begin{array}{l}\text { Instrumental } \\
\text { vaginal birth }\end{array}$ & NR & - & - & - & - \\
\hline $\begin{array}{l}\text { Maternal mor- } \\
\text { tality }\end{array}$ & $\begin{array}{l}\text { Implementation of clinical practice guidelines } \\
\text { combined with mandatory second opinion for } \\
\text { caesarean section indication results in little or } \\
\text { no difference in maternal mortality compared } \\
\text { to routine maternity care }\end{array}$ & $\begin{array}{l}\text { Mean baseline } \\
\text { rate per 10,000 } \\
\text { livebirths ( } 39175 \\
\text { women): } 5.9 \\
\text { Mean follow-up } \\
\text { rate per } 10,000 \\
\text { livebirths ( } 39638 \\
\text { women): } 7.5\end{array}$ & $\begin{array}{l}\text { Mean baseline rate } \\
\text { per } 10,000 \text { livebirths } \\
\text { ( } 34735 \text { women): } 3.2 \\
\text { Mean follow-up rate } \\
\text { per } 10,000 \text { livebirths } \\
\text { (35 } 675 \text { women): } 4.3\end{array}$ & $\begin{array}{l}\text { Mean difference } \\
\text { in rate change: } \\
0.66 \text { (-4.0 to } 5.3 \text { ) } \\
\text { (re-analysed) }\end{array}$ & $\begin{array}{l}\oplus \oplus \oplus \oplus \\
\text { HIGH }\end{array}$ \\
\hline $\begin{array}{l}\text { Maternal mor- } \\
\text { bidity }\end{array}$ & NR & - & - & - & - \\
\hline $\begin{array}{l}\text { Neonatal mor- } \\
\text { tality }\end{array}$ & $\begin{array}{l}\text { Implementation of clinical practice guidelines } \\
\text { combined with mandatory second opinion for } \\
\text { caesarean section indication results in little or } \\
\text { no difference in neonatal mortality compared } \\
\text { to routine maternity care }\end{array}$ & $\begin{array}{l}\text { Mean baseline rate } \\
\text { ( } 39,175 \text { women): } \\
1.1 \\
\text { Mean follow-up } \\
\text { rate }(39,638 \\
\text { women): } 1.0 \\
\text { Mean rate change: } \\
-0.1\end{array}$ & $\begin{array}{l}\text { Mean baseline rate } \\
(34,735 \text { women): } 1.1 \\
\text { Mean follow-up rate } \\
\text { per } 10,000 \text { livebirths } \\
\text { ( } 35675 \text { women): } 0.9 \\
\text { Mean rate change: } \\
-0.2\end{array}$ & $\begin{array}{l}\text { Mean difference } \\
\text { in rate change } \\
(95 \% \mathrm{Cl}) \text { : } \\
-0.1(-0.4 \text { to } 0.3)\end{array}$ & $\begin{array}{l}\oplus \oplus \oplus \oplus \\
\mathbf{H I G H}\end{array}$ \\
\hline $\begin{array}{l}\text { Neonatal mor- } \\
\text { bidity }\end{array}$ & $\begin{array}{l}\text { Implementation of clinical practice guidelines } \\
\text { combined with mandatory second opinion for } \\
\text { caesarean section indication results in little } \\
\text { or no difference in Intrapartum foetal distress } \\
\text { compared to routine maternity care }\end{array}$ & $\begin{array}{l}\text { Mean baseline rate } \\
(39,175 \text { women): } \\
3.1 \\
\text { Mean follow-up } \\
\text { rate }(39,638 \\
\text { women): } 3.1 \\
\text { Mean rate change: } \\
0.0\end{array}$ & $\begin{array}{l}\text { Mean baseline rate } \\
(34,735 \text { women): } 4.3 \\
\text { Mean follow-up rate } \\
\text { per } 10,000 \text { livebirths } \\
\text { ( } 35675 \text { women): } 3.4 \\
\text { Mean rate change: } \\
-1.0\end{array}$ & $\begin{array}{l}\text { Mean difference } \\
\text { in rate change } \\
(95 \% \mathrm{Cl}) \text { : } \\
-0.9(-1.9 \text { to }- \\
0.0)\end{array}$ & $\begin{array}{l}\oplus \oplus \oplus \oplus \\
\text { HIGH }\end{array}$ \\
\hline $\begin{array}{l}\text { Caesarean sec- } \\
\text { tion - overall }\end{array}$ & $\begin{array}{l}\text { Implementation of clinical practice guidelines } \\
\text { combined with audit and feedback slightly re- }\end{array}$ & $\begin{array}{l}\text { Baseline: } \\
6671 / 28,698 \\
(23.2 \%)\end{array}$ & $\begin{array}{l}\text { Baseline: } \\
\text { 5484/24,388 (22.5\%) }\end{array}$ & $\begin{array}{l}\mathrm{RD}-1.8 \%(-3.8 \\
\text { to }-0.2)\end{array}$ & $\begin{array}{l}\oplus \oplus \oplus \oplus \\
\text { HIGH }\end{array}$ \\
\hline
\end{tabular}

(39,175 women):

Mean baseline rate

(39,175 women):

Mean follow-up

rate $(39,638$

Mean rate change:

Baseline:

(2)

\section{eline rate \\ Mean follow-up rate \\ per 10,000 livebirths}

$0.66(-4.0$ to 5.3$)$

(re-analysed) 
lines combined with audit and feedback

(Canada)

(Chaillet 2015, cluster-ran-

domised trial) duces the overall caesarean section rate compared to routine maternity care

Post-interven

tion: $6767 / 28,781$

(23.5\%)

\begin{tabular}{ll}
\hline Caesarean sec- & Implementation of clinical practice guidelines \\
tion - low risk & combined with audit and feedback slightly re- \\
group & $\begin{array}{l}\text { duces caesarean section rate compared to rou- } \\
\text { tine maternity care }\end{array}$
\end{tabular}

Baseline:

1256/14,717 (8.5\%)

Post-intervention:

$1172 / 13,019(9.0 \%)$ ost-intervention:

5128/23,484 (21.8\%)

Baseline: $971 / 11,478$

RD $-1.7 \%(-3.0$

Post-intervention:

$63 / 10,067$

$(7.6 \%)$

\begin{tabular}{lllll}
\hline $\begin{array}{l}\text { Elective repeat } \\
\text { caesarean sec- } \\
\text { tion }\end{array}$ & $\begin{array}{l}\text { Implementation of clinical practice guidelines } \\
\text { plus audit and feedback results in little or no } \\
\text { difference in elective repeat caesarean sec- } \\
\text { tion rate compared to routine maternity care }\end{array}$ & Baseline: & Baseline: & RD $-0.6 \%(-0.07$ \\
& groups & $\begin{array}{l}\text { Post-intervention: } \\
\text { 2598/28,781 (9.0\%) }\end{array}$ & $\begin{array}{l}\text { Post-intervention: } \\
1931 / 23,484(8.2 \%)\end{array}$
\end{tabular}

Spontaneous NR

vaginal birth

\begin{tabular}{|c|c|c|c|c|c|}
\hline $\begin{array}{l}\text { Instrumental } \\
\text { vaginal birth }\end{array}$ & NR & - & - & - & - \\
\hline $\begin{array}{l}\text { Major maternal } \\
\text { morbidity }\end{array}$ & $\begin{array}{l}\text { Implementation of clinical practice guidelines } \\
\text { combined with audit and feedback results in } \\
\text { little or no difference in major maternal mor- } \\
\text { bidity compared to routine maternity care }\end{array}$ & $\begin{array}{l}\text { Baseline: } \\
\text { 138/28,698 (0.48\%) } \\
\text { Post-intervention: } \\
141 / 28,781(0.49 \%)\end{array}$ & $\begin{array}{l}\text { Baseline: } \\
\text { 161/24,388 (0.66\%) } \\
\text { Post-intervention: } \\
\text { 167/23,484 (0.71\%) }\end{array}$ & $\begin{array}{l}\text { RD } 0.03 \% \\
(-0.11 \text { to } 0.23)\end{array}$ & $\begin{array}{l}\oplus \oplus \oplus \oplus \\
\text { HIGH }\end{array}$ \\
\hline $\begin{array}{l}\text { Minor maternal } \\
\text { morbidity }\end{array}$ & $\begin{array}{l}\text { Implementation of clinical practice guidelines } \\
\text { combined with audit and feedback results in } \\
\text { little or no difference in minor maternal mor- } \\
\text { bidity compared to routine maternity care }\end{array}$ & $\begin{array}{l}\text { Baseline: } \\
3869 / 28,698 \\
(13.5 \%) \\
\text { Post-intervention: } \\
4244 / 28,781 \\
(14.7 \%)\end{array}$ & $\begin{array}{l}\text { Baseline: } \\
\text { 3293/24,388 (13.5\%) } \\
\text { Post-intervention: } \\
\text { 3576/23,484 (15.2\%) }\end{array}$ & $\begin{array}{l}\text { RD 0.3\% } \\
(-1.2 \text { to } 1.8)\end{array}$ & \\
\hline $\begin{array}{l}\text { Major neonatal } \\
\text { morbidity }\end{array}$ & $\begin{array}{l}\text { Implementation of clinical practice guidelines } \\
\text { combined with audit and feedback results in } \\
\text { little or no difference in major neonatal mor- } \\
\text { bidity compared to routine maternity care }\end{array}$ & $\begin{array}{l}\text { Baseline: } \\
\text { 1018/29,107 (3.5\%) } \\
\text { Post-intervention: }\end{array}$ & $\begin{array}{l}\text { Baseline: } \\
\text { 1172/24,823 (4.7\%) } \\
\text { Post-intervention: }\end{array}$ & $\begin{array}{l}\text { RD }-0.7 \% \\
(-1.3 \text { to }-0.1)\end{array}$ & \\
\hline
\end{tabular}




\begin{tabular}{|c|c|c|c|c|c|c|}
\hline \multirow{9}{*}{ 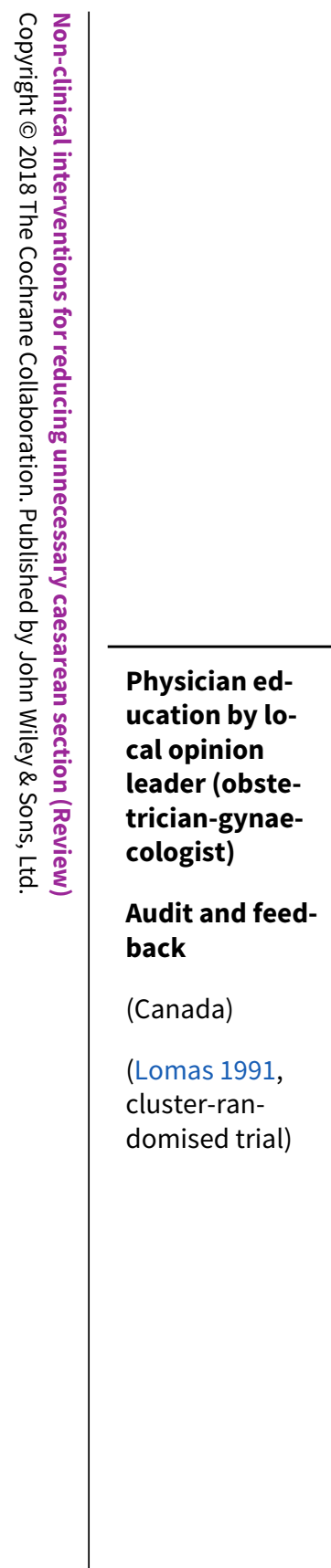 } & \multirow{2}{*}{$\begin{array}{l}\text { Minor neonatal } \\
\text { morbidity }\end{array}$} & \multirow[b]{2}{*}{$\begin{array}{l}\text { Implementation of clinical practice guidelines } \\
\text { combined with audit and feedback results in } \\
\text { little or no difference in minor neonatal mor- } \\
\text { bidity compared to routine maternity care }\end{array}$} & \multirow[b]{2}{*}{$\begin{array}{l}\text { 1156/29,211 (4.0\%) } \\
\text { Baseline: } \\
3947 / 29,107 \\
(13.6 \%) \\
\text { Post-intervention: } \\
5002 / 29,211 \\
(17.1 \%)\end{array}$} & \multicolumn{2}{|l|}{$1070 / 23,902(4.5 \%)$} & \\
\hline & & & & $\begin{array}{l}\text { Baseline: } \\
\text { 3936/25,823 (15.9\%) } \\
\text { Post-intervention: } \\
\text { 4261/23,902 (17.8\%) }\end{array}$ & $\begin{array}{l}\mathrm{RD}-1.7 \% \\
(-2.6 \text { to }-0.9)\end{array}$ & \\
\hline & $\begin{array}{l}\text { Intrapartum } \\
\text { and neonatal } \\
\text { deaths }\end{array}$ & $\begin{array}{l}\text { Implementation of clinical practice guidelines } \\
\text { combined with audit and feedback results } \\
\text { in little or no difference in intrapartum and } \\
\text { neonatal deaths compared to routine materni- } \\
\text { ty care }\end{array}$ & $\begin{array}{l}\text { Baseline: } \\
\text { 14/29 } 107(0.0 \%) \\
\text { Post-intervention: } \\
28 / 29,211(0.0 \%)\end{array}$ & $\begin{array}{l}\text { Baseline: } \\
35 / 24823(0.1 \%) \\
\text { Post-intervention: } \\
20 / 23,902(0.1 \%)\end{array}$ & $\begin{array}{l}\text { RD }-0.06 \% \\
(-0.08 \text { to }-0.03)\end{array}$ & \\
\hline & $\begin{array}{l}\text { Caesarean sec- } \\
\text { tion - elective }\end{array}$ & $\begin{array}{l}\text { Physician education by local opinion leader } \\
\text { (obstetrician-gynaecologist) reduced elective } \\
\text { caesarean section compared to routine mater- } \\
\text { nity care }\end{array}$ & $\begin{array}{l}\text { Control: } \\
66.8 \% \text { ( } 61.7 \text { to } 72.0)\end{array}$ & $\begin{array}{l}\text { Opinion leader edu- } \\
\text { cation: } \\
53.7 \%(46.5 \text { to } 61.0)\end{array}$ & - & $\begin{array}{l}\oplus \oplus \oplus \oplus \\
\text { HIGH }\end{array}$ \\
\hline & & $\begin{array}{l}\text { Audit and feedback results in little or no differ- } \\
\text { ence in elective caesarean section compared to } \\
\text { routine maternity care }\end{array}$ & $\begin{array}{l}\text { Control: } \\
66.8 \%(61.7 \text { to } 72.0)\end{array}$ & $\begin{array}{l}\text { Audit and feedback: } \\
69.7 \%(62.4 \text { to } 77.0)\end{array}$ & - & \\
\hline & $\begin{array}{l}\text { Caesarean sec- } \\
\text { tion - unsched- } \\
\text { uled }\end{array}$ & $\begin{array}{l}\text { There was no difference in unscheduled cae- } \\
\text { sarean section between opinion leader educa- } \\
\text { tion (obstetrician-gynaecologist) and routine } \\
\text { maternity care }\end{array}$ & $\begin{array}{l}\text { Control: } \\
18.7 \% \text { (15.4 to } 22.1 \text { ) }\end{array}$ & $\begin{array}{l}\text { Opinion leader edu- } \\
\text { cation: } \\
21.4 \%(16.8 \text { to } 26.1)\end{array}$ & - & \\
\hline & & $\begin{array}{l}\text { Audit and feedback results in little or no differ- } \\
\text { ence in unscheduled caesarean section rate } \\
\text { compared to routine maternity care }\end{array}$ & $\begin{array}{l}\text { Control: } \\
18.7 \%(15.4 \text { to } 22.1)\end{array}$ & $\begin{array}{l}\text { Audit and feedback: } \\
18.6 \% \text { (13.9 to } 23.2)\end{array}$ & - & \\
\hline & $\begin{array}{l}\text { Spontaneous } \\
\text { vaginal birth }\end{array}$ & $\begin{array}{l}\text { Physician education by opinion leader (obste- } \\
\text { trician-gynaecologist) increases vaginal birth } \\
\text { compared to routine maternity care }\end{array}$ & $\begin{array}{l}\text { Control: } \\
14.5 \%(10.3 \text { to } 18.7)\end{array}$ & $\begin{array}{l}\text { Opinion leader edu- } \\
\text { cation: } \\
25.3 \%(19.3 \text { to } 31.2)\end{array}$ & - & \\
\hline & & $\begin{array}{l}\text { Audit and feedback results in little or no differ- } \\
\text { ence in spontaneous vaginal birth rate com- } \\
\text { pared to routine maternity care }\end{array}$ & $\begin{array}{l}\text { Control: } \\
14.5 \%(10.3 \text { to } 18.7)\end{array}$ & $\begin{array}{l}\text { Audit and feedback: } \\
11.8 \%(5.8 \text { to } 17.7)\end{array}$ & - & \\
\hline
\end{tabular}




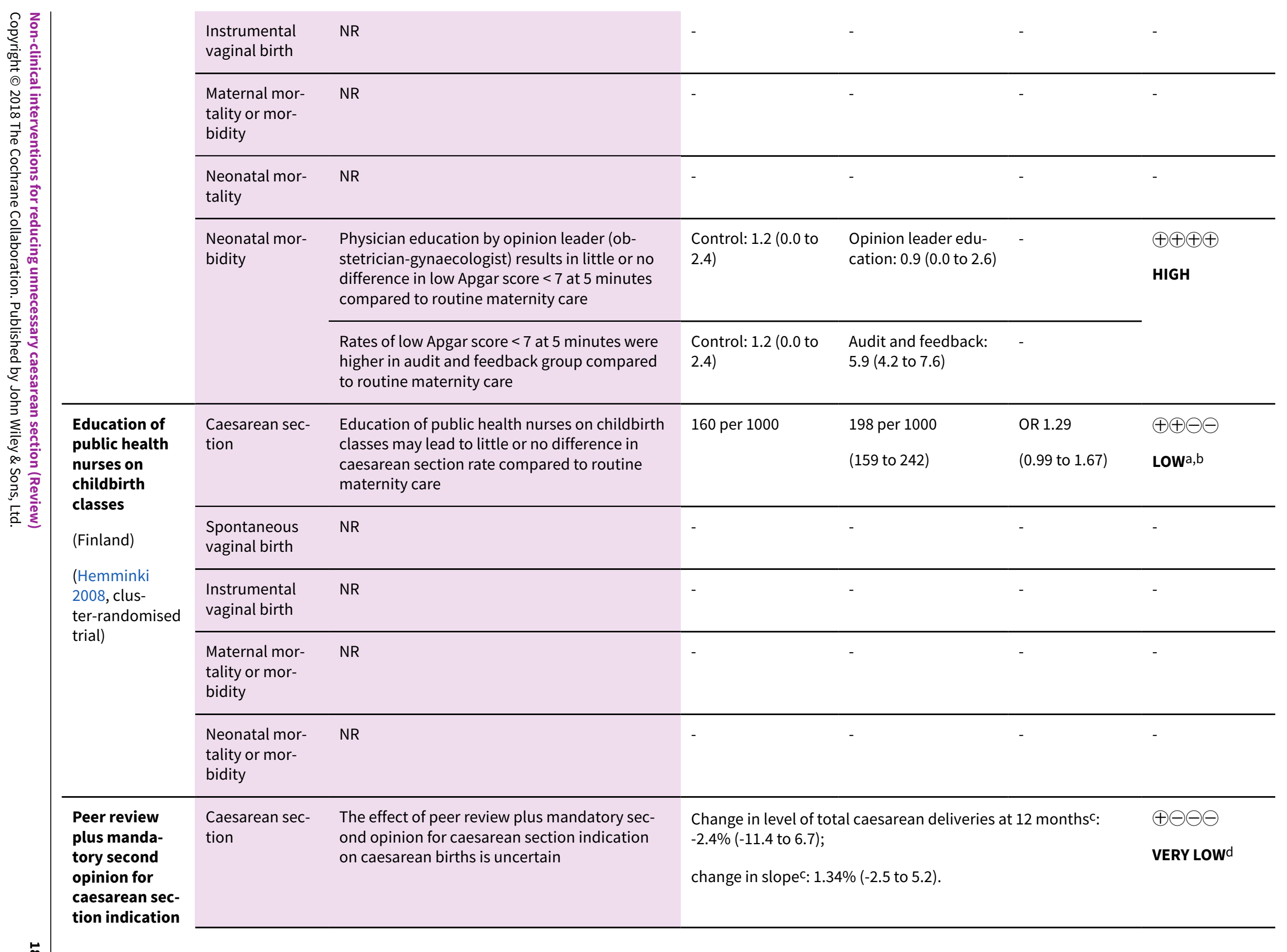




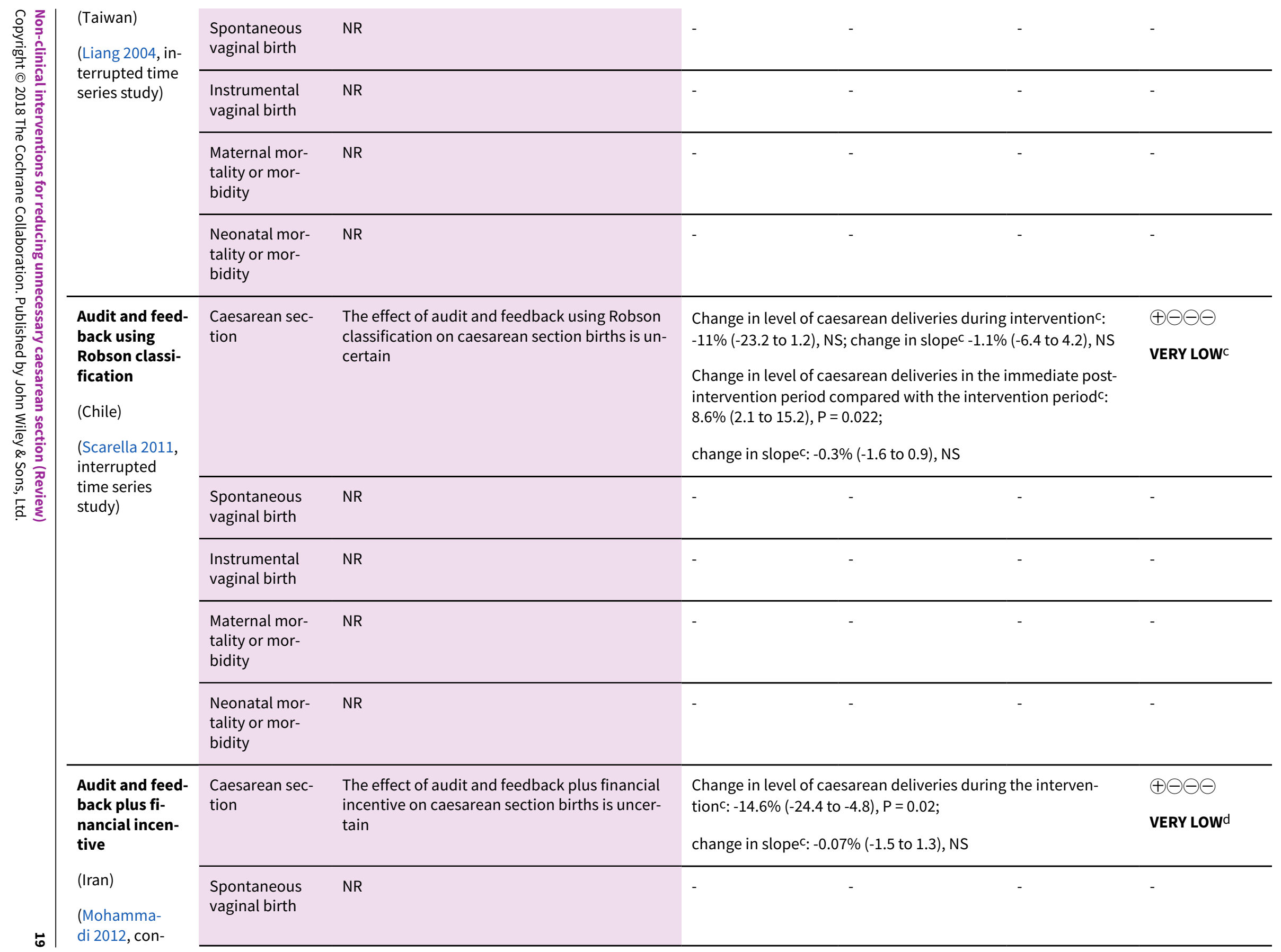


bidity

Neonatal mor- NR

tality or mor-

NR

bidity

\begin{tabular}{|c|c|c|c|c|c|}
\hline \multirow{5}{*}{$\begin{array}{l}\text { Audit and feed- } \\
\text { back plus 24- } \\
\text { hour in-house } \\
\text { coverage by } \\
\text { dedicated } \\
\text { physician } \\
\text { (USA) } \\
\text { (Poma 1998, in- } \\
\text { terrupted time } \\
\text { series study) }\end{array}$} & $\begin{array}{l}\text { Caesarean sec- } \\
\text { tion }\end{array}$ & $\begin{array}{l}\text { The effect of audit and feedback plus } 24 \text {-hour } \\
\text { in-house coverage by a dedicated physician on } \\
\text { caesarean section births is uncertain }\end{array}$ & \multicolumn{2}{|c|}{$\begin{array}{l}\text { Change in level of total caesarean deliveries (primary and re- } \\
\text { peat caesarean sections) at } 24 \text { monthsc: }-6.6 \%(-10.1 \text { to }-3.2) \text {; } \\
\text { change in slopec: }-0.11 \%(-0.25 \text { to } 0.02) \text { (data reanalysed) }\end{array}$} & \multirow{2}{*}{$\begin{array}{l}\oplus \ominus \ominus \ominus \\
\text { VERY LOWd } \\
-\end{array}$} \\
\hline & $\begin{array}{l}\text { Spontaneous } \\
\text { vaginal birth }\end{array}$ & NR & - & - & \\
\hline & $\begin{array}{l}\text { Instrumental } \\
\text { vaginal birth }\end{array}$ & NR & - & - & - \\
\hline & $\begin{array}{l}\text { Maternal mor- } \\
\text { tality or mor- } \\
\text { bidity }\end{array}$ & NR & - & - & - \\
\hline & $\begin{array}{l}\text { Neonatal mor- } \\
\text { tality or mor- } \\
\text { bidity }\end{array}$ & NR & - & - & - \\
\hline
\end{tabular}

¥The corresponding risk (absolute effect with intervention) (and its 95\% confidence interval) is based on the assumed risk in the comparison group ((i.e. risk with control) and the relative effect of the intervention (and its 95\% Cl).

About the certainty of the evidence (GRADE)*

High: this research provides a very good indication of the likely effect; the likelihood that the effect will be substantially different ${ }^{\dagger}$ is low.

Moderate: this research provides a good indication of the likely effect; the likelihood that the effect will be substantially different ${ }^{\dagger}$ is moderate.

Low: this research provides some indication of the likely effect; however, the likelihood that it will be substantially different ${ }^{\dagger}$ is high.

Very low: this research does not provide a reliable indication of the likely effect; the likelihood that the effect will be substantially different ${ }^{\dagger}$ is very high.

"This is sometimes referred to as 'quality of evidence' or 'confidence in the estimate'

†Substantially different $=$ a large enough difference that it might affect a decision

Cl: confidence interval; NR: not reported; NS: not significant; RD: risk difference; RR: risk ratio. 
aDowngraded one level for serious risk of bias (pilot study with no sample size calculation; unit of analysis error).

bowngraded one level for serious imprecision (confidence interval includes null effect)

CTwo standardised effect sizes are obtained from ITS analysis: change in level (also called 'step change') and change in trend (also called 'change in slope') before and after the intervention. Change in level = difference between the observed level at the first intervention time point and that predicted by the pre-intervention time trend; Change in trend = difference between post- and pre-intervention slopes. A negative change in level and slope indicates a reduction in caesarean section rate.

dDowngraded one level for possible confounding (unclear whether the intervention occurred independently of other changes over time).

Summary of findings 3. Interventions targeted at healthcare organisations or facilities

\begin{tabular}{|c|c|c|c|c|c|c|}
\hline \multirow[t]{2}{*}{ Intervention } & \multirow{2}{*}{$\begin{array}{l}\text { Primary outcome } \\
\text { measure }\end{array}$} & \multirow[t]{2}{*}{ Plain language summary } & \multicolumn{2}{|c|}{ Absolute effect $\ddagger$} & \multirow{2}{*}{$\begin{array}{l}\text { Relative effect } \\
(95 \% \mathrm{Cl})\end{array}$} & \multirow{2}{*}{$\begin{array}{l}\text { Certainty } \\
\text { (GRADE) }\end{array}$} \\
\hline & & & with control & $\begin{array}{l}\text { with intervention } \\
(95 \% \mathrm{Cl})\end{array}$ & & \\
\hline
\end{tabular}

Financial interventions targeted at healthcare professionals

Insurance reforms Caesarean section The effect of insurance reforms equalequalising physi-

cian fees for vagi-

nal and caesarean section deliveries

(Keeler 1996, interrupted time series study)

\begin{tabular}{ll}
\hline $\begin{array}{l}\text { Spontaneous vagi- } \\
\text { nal birth }\end{array}$ & NR \\
\hline $\begin{array}{l}\text { Instrumental vagi- } \\
\text { nal birth }\end{array}$ & NR \\
\hline $\begin{array}{l}\text { Maternal mortality } \\
\text { or morbidity }\end{array}$ & NR \\
\hline $\begin{array}{l}\text { Neonatal mortality } \\
\text { or morbidity }\end{array}$ & NR \\
\hline
\end{tabular}

Insurance reforms equalising physi-

Caesarean section

The effect of insurance reforms equalising physician fees for vaginal and caesarean section deliveries on caecian fees for vaginal and caesarean sarean births is uncertain section deliveries

The change in the level of total caesarean section rate (for all indications and order of birth) following the rise in vaginal birth

The change in the level of total caesarean section rate following the rise in VBAC fees was $-1.68(95 \% \mathrm{Cl}-2.3$ to -1.07$)$; the change in slope was $-0.004(95 \% \mathrm{Cl}-0.05 \text { to } 0.04)^{\mathrm{b}}$

$\oplus \ominus \ominus \ominus$

Caesarean section rates for non-breech deliveries decreased by $\quad \oplus \Theta \Theta \Theta$

VERY LOWa

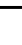

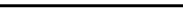

\section{VERY LOWa}




\begin{tabular}{|c|c|c|c|c|c|c|}
\hline \multirow{5}{*}{ 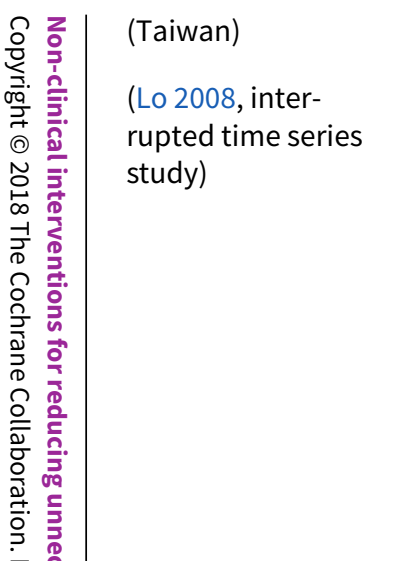 } & & & \multicolumn{4}{|c|}{$\begin{array}{l}\text { fees was } 1.19(95 \% \mathrm{Cl}-0.01 \text { to } 2.40) \text { and the change in slope was } \\
-0.43(95 \% \mathrm{Cl}-0.78 \text { to }-0.09)^{\mathrm{b}}\end{array}$} \\
\hline & $\begin{array}{l}\text { Spontaneous vagi- } \\
\text { nal birth }\end{array}$ & NR & - & - & - & - \\
\hline & $\begin{array}{l}\text { Instrumental vagi- } \\
\text { nal birth }\end{array}$ & NR & - & - & - & - \\
\hline & $\begin{array}{l}\text { Maternal mortality } \\
\text { or morbidity }\end{array}$ & NR & - & - & - & - \\
\hline & $\begin{array}{l}\text { Neonatal mortality } \\
\text { or morbidity }\end{array}$ & NR & - & - & - & - \\
\hline \multicolumn{7}{|c|}{ Different staffing models of delivery care } \\
\hline \multirow{5}{*}{$\begin{array}{l}\text { Collabora- } \\
\text { tive mid- } \\
\text { wifery-labourist } \\
\text { care (versus pri- } \\
\text { vate model of } \\
\text { care) } \\
\text { (USA) } \\
\text { (Rosenstein 2015, } \\
\text { interrupted time } \\
\text { series study) }\end{array}$} & $\begin{array}{l}\text { Primary caesarean } \\
\text { section }\end{array}$ & $\begin{array}{l}\text { Collaborative midwifery-labourist care } \\
\text { may reduce primary caesarean section } \\
\text { compared to private model of care }\end{array}$ & \multicolumn{3}{|c|}{$\begin{array}{l}\text { Primary caesarean rate among privately insured women de- } \\
\text { creased from } 31.7 \% \text { to } 25.0 \% \text { (OR } 0.56,95 \% \mathrm{Cl} 0.39 \text { to } 0.81 \text { ). Inter- } \\
\text { rupted time series analysis estimated a } 7 \% \text { drop in the primary } \\
\text { caesarean rate in the year after the intervention, and a decrease } \\
\text { of } 1.7 \% \text { per year thereafter }\end{array}$} & $\begin{array}{l}\oplus \oplus \ominus \ominus \\
\text { Lowc }\end{array}$ \\
\hline & VBAC & $\begin{array}{l}\text { Collaborative midwifery-labourist care } \\
\text { may increase VBAC compared to pri- } \\
\text { vate model of care }\end{array}$ & \multicolumn{3}{|c|}{$\begin{array}{l}\text { VBAC rate increased from } 13.3 \% \text { before to } 22.4 \% \text { after the inter- } \\
\text { vention (OR } 2.03,95 \% \mathrm{Cl} 1.08 \text { to } 3.80 \text { ) }\end{array}$} & \\
\hline & $\begin{array}{l}\text { Instrumental vagi- } \\
\text { nal birth }\end{array}$ & NR & - & - & - & - \\
\hline & $\begin{array}{l}\text { Maternal mortality } \\
\text { or morbidity }\end{array}$ & NR & - & - & - & - \\
\hline & $\begin{array}{l}\text { Neonatal mortality } \\
\text { or morbidity }\end{array}$ & NR & - & - & - & - \\
\hline $\begin{array}{l}\text { Labourist model } \\
\text { of obstetric care } \\
\text { (versus traditional } \\
\text { model of obstetric } \\
\text { care) } \\
\text { (USA) }\end{array}$ & Caesarean section & $\begin{array}{l}\text { Labourist model of obstetric care may } \\
\text { lead to little or no difference in cae- } \\
\text { sarean section rate compared to tradi- } \\
\text { tional model of obstetric care }\end{array}$ & $\begin{array}{l}\text { Non-labourist be- } \\
\text { fore: } \\
28.5 \% \text { ( } 46,486 \text { births) } \\
\text { Non-labourist after: } \\
31.8 \% \text { (42,348 births) }\end{array}$ & $\begin{array}{l}\text { Labourist before: } \\
32.6 \% \text { ( } 47,206 \text { births) } \\
\text { Labourist after: } \\
33.6 \% \text { (35,210 births) }\end{array}$ & $\begin{array}{l}\text { OR } 1.02 \\
(0.97 \text { to } 1.1)\end{array}$ & $\begin{array}{l}\oplus \oplus \ominus \ominus \\
\text { Lowc }\end{array}$ \\
\hline
\end{tabular}




\begin{tabular}{|c|c|c|c|c|c|}
\hline $\begin{array}{l}\text { Instrumental vagi- } \\
\text { nal birth }\end{array}$ & NR & - & - & - & - \\
\hline Maternal mortality & NR & - & - & - & - \\
\hline Maternal morbidity & $\begin{array}{l}\text { Labourist model of obstetric care } \\
\text { may lead to little or no difference in } \\
\text { chorioamnionitis compared to tradi- } \\
\text { tional model of obstetric care }\end{array}$ & $\begin{array}{l}\text { Non-labourist be- } \\
\text { fore, } \%(\mathrm{~N}): 6.2 \\
(10,018) \\
\text { Non-labourist be- } \\
\text { fore, \% (N): } 4.8(6339)\end{array}$ & $\begin{array}{l}\text { Labourist before, } \% \\
(\mathrm{~N}): 3.8(5549) \\
\text { Labourist after, \% } \\
(\mathrm{N}): 3.5(3814)\end{array}$ & $\begin{array}{l}\text { OR } 1.07 \text { (0.88 to } \\
1.30)\end{array}$ & $\begin{array}{l}\oplus \oplus \ominus \ominus \\
\text { LOWc }\end{array}$ \\
\hline Neonatal mortality & NR & - & - & - & - \\
\hline \multirow[t]{2}{*}{ Neonatal morbidity } & $\begin{array}{l}\text { Labourist model of obstetric care may } \\
\text { lead to little or no difference in low } \\
\text { Apgar (less than } 7 \text { ) at } 5 \text { minutes com- } \\
\text { pared to traditional model of obstetric } \\
\text { care }\end{array}$ & $\begin{array}{l}\text { Non-labourist be- } \\
\text { fore, \% (N): } 0.4(557) \\
\text { Non-labourist after, } \\
\%(N): 0.4(476)\end{array}$ & $\begin{array}{l}\text { Labourist before, } \% \\
(\mathrm{~N}): 0.2(216) \\
\text { Labourist after, \% } \\
(\mathrm{N}): 0.2(223)\end{array}$ & $\begin{array}{l}\text { OR } 1.09 \text { ( } 0.69 \text { to } \\
1.72)\end{array}$ & $\begin{array}{l}\oplus \oplus \ominus \ominus \\
\text { LOWc }\end{array}$ \\
\hline & $\begin{array}{l}\text { Labourist model of obstetric care may } \\
\text { lead to little or no difference in birth } \\
\text { asphyxia compared to traditional } \\
\text { model of obstetric care }\end{array}$ & $\begin{array}{l}\text { Non-labourist be- } \\
\text { fore, \% (N): } 0.3(398) \\
\text { Non-labourist after, } \\
\%(\mathrm{~N}) \text { : } \\
0.2(247)\end{array}$ & $\begin{array}{l}\text { Labourist before, } \% \\
\text { (N): } 0.2(310) \\
\text { Labourist after, \% } \\
\text { (N): } 0.2(171)\end{array}$ & $\begin{array}{l}\text { OR } 0.75 \text { (0.48 to } \\
1.18 \text { ) }\end{array}$ & $\begin{array}{l}\oplus \oplus \Theta \Theta \\
\text { Lowc }\end{array}$ \\
\hline
\end{tabular}

The corresponding risk (absolute effect with intervention) (and its 95\% confidence interval) is based on the assumed risk in the comparison group ((i.e. risk with control) and the relative effect of the intervention (and its $95 \% \mathrm{Cl}$ ).

About the certainty of the evidence (GRADE)*

High: this research provides a very good indication of the likely effect; the likelihood that the effect will be substantially different ${ }^{\dagger}$ is low.

Moderate: this research provides a good indication of the likely effect; the likelihood that the effect will be substantially different ${ }^{\dagger}$ is moderate.

Low: this research provides some indication of the likely effect; however, the likelihood that it will be substantially different ${ }^{\dagger}$ is high.

Very low: this research does not provide a reliable indication of the likely effect; the likelihood that the effect will be substantially different ${ }^{\dagger}$ is very high

"This is sometimes referred to as 'quality of evidence' or 'confidence in the estimate'

†Substantially different $=$ a large enough difference that it might affect a decision

Cl: confidence interval; NR: not reported; OR: odds ratio; RR: risk ratio; VBAC: vaginal birth after caesarean. 
aDowngraded one level for serious risk of bias (due to possible confounding of outcome; unclear whether the intervention occurred independently of other changes over time).

bTwo standardised effect sizes are obtained from interrupted time series analysis: a change in level (also called 'step change') and a change in trend (also called 'change in slope') before and after the intervention.

Change in level = difference between the observed level at the first intervention time point and that predicted by the pre-intervention time trend; change in trend = difference between post- and pre-intervention slopes. A negative change in level and slope indicates a reduction in caesarean section rate.

cObservational study which start at low certainty evidence according to GRADE (we did not downgrade or upgrade the certainty of evidence).

Summary of findings 4. 'Cross-cutting' interventionsa

\begin{tabular}{|c|c|c|c|c|c|c|}
\hline \multirow[t]{2}{*}{ Intervention } & \multirow{2}{*}{$\begin{array}{l}\text { Primary outcome } \\
\text { measure }\end{array}$} & \multirow[t]{2}{*}{ Plain language summary } & \multicolumn{2}{|c|}{ Absolute effect $\neq$} & \multirow{2}{*}{$\begin{array}{l}\text { Relative effect } \\
(95 \% \mathrm{Cl})\end{array}$} & \multirow{2}{*}{$\begin{array}{l}\text { Certainty } \\
\text { (GRADE) }\end{array}$} \\
\hline & & & with control & with intervention & & \\
\hline \multirow{2}{*}{$\begin{array}{l}\text { Multifaceted programme com- } \\
\text { prising education programme } \\
\text { for hospital staff and women, } \\
\text { audit of surgeon practices, pub- } \\
\text { lic health campaign, monitor- } \\
\text { ing rates of caesarean sections } \\
\text { and neonatal outcomes }\end{array}$} & Caesarean section & $\begin{array}{l}\text { The effect of multifaceted } \\
\text { programme on caesarean } \\
\text { section rate is uncertain }\end{array}$ & \multicolumn{3}{|c|}{$\begin{array}{l}\text { Change in level of caesarean deliveries during intervention: } \\
-13.4 \%(95 \% \mathrm{Cl}-19.6 \text { to }-7.1)^{\mathrm{b}} \\
\text { Change in slope of caesarean deliveries: }-0.72 \%(95 \% \mathrm{Cl}-3 \text { to } \\
1.5)^{\mathrm{b}}\end{array}$} & $\begin{array}{l}\oplus \ominus \ominus \ominus \\
\text { VERY LOWc }\end{array}$ \\
\hline & $\begin{array}{l}\text { Spontaneous vagi- } \\
\text { nal birth }\end{array}$ & NR & - & - & - & - \\
\hline \multirow[t]{5}{*}{$\begin{array}{l}\text { (Runmei 2012, controlled be- } \\
\text { fore-after study) }\end{array}$} & $\begin{array}{l}\text { Instrumental vagi- } \\
\text { nal birth }\end{array}$ & NR & - & - & - & - \\
\hline & Maternal mortality & NR & - & - & - & - \\
\hline & Maternal morbidity & $\begin{array}{l}\text { The effect of multifaceted } \\
\text { programme on maternal } \\
\text { morbidity is uncertain }\end{array}$ & \multicolumn{3}{|c|}{$\begin{array}{l}\text { "We found a significant increase in the incidence of all obstetric } \\
\text { complications, with the exception of placental abruption, after } \\
2004 \text { " }\end{array}$} & $\begin{array}{l}\oplus \ominus \ominus \ominus \\
\text { VERY LOWc }\end{array}$ \\
\hline & Neonatal morbidity & NR & - & - & - & - \\
\hline & Neonatal morbidity & $\begin{array}{l}\text { The effect of multifaceted } \\
\text { programme on neonatal } \\
\text { morbidity is uncertain }\end{array}$ & \multicolumn{3}{|c|}{$\begin{array}{l}\text { "The incidence of birth asphyxia did not increase after } 2004 \text { (P } \\
=0.303) "\end{array}$} & $\begin{array}{l}\oplus \ominus \ominus \ominus \\
\text { VERY LOWc }\end{array}$ \\
\hline
\end{tabular}


Maternal or neona- NR

tal mortality

\section{Multifaceted programme com-} prising transmission of infor-

mation on caesarean section,

training of health workers on

best obstetric practices and in-

clusion of caesarean section

rates as a criterion for hospital

Caesarean section The effect of multifaceted

programme on rates of

In the period between 2009 and 2014, representing the possi-

$\oplus \ominus \ominus \ominus$

VBAC

caesarean section, VBAC

VERY LOWc

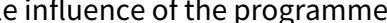

rates of caesarean section in the study region decreased by

$20.0 \%$ (from $36.0 \%$ to $28.8 \%$, time trend $\mathrm{P}<0.001$ ) ,

rates of instrumental vaginal delivery increased by $33.1 \%$ (from

$13.7 \%$ to $18.2 \%$, time trend $\mathrm{P}<0.001)^{\mathrm{b}}$;

\section{(Portugal)}

(Ayres-De-Campos 2015, interrupted time series study)

$$
\text { nal birth }
$$

uncertain

rates of VBAC increased by $99.8 \%$ (from $16.4 \%$ to $32.8 \%$, time trend $\mathrm{P}<0.001)^{\mathrm{b}}$

\begin{tabular}{llllll}
\hline $\begin{array}{l}\text { Spontaneous vagi- } \\
\text { nal birth }\end{array}$ & NR & - & - & - \\
\hline $\begin{array}{l}\text { Maternal mortality } \\
\text { or morbidity }\end{array}$ & NR & - & - & - \\
\hline Neonatal mortality & NR & - & - & - \\
\hline Neonatal morbidity & $\begin{array}{l}\text { The effect of multifaceted } \\
\text { programme on hypox- } \\
\text { ia-related complications is } \\
\text { uncertain }\end{array}$ & $\begin{array}{l}\text { The incidence of hypoxia-related complications decreased by } \\
14.1 \% \text { (from } 0.71 \% \text { to } 0.61 \% \text {, time trend P < 0.001) }\end{array}$ & $\Theta$ \\
VERY LOWc &
\end{tabular}

¥The corresponding risk (absolute effect with intervention) (and its $95 \%$ confidence interval) is based on the assumed risk in the comparison group ((i.e. risk with control) and the relative effect of the intervention (and its $95 \% \mathrm{Cl}$ ).

About the certainty of the evidence (GRADE)*

High: this research provides a very good indication of the likely effect; the likelihood that the effect will be substantially different ${ }^{\dagger}$ is low.

Moderate: this research provides a good indication of the likely effect; the likelihood that the effect will be substantially different ${ }^{\dagger}$ is moderate

Low: this research provides some indication of the likely effect; however, the likelihood that it will be substantially different ${ }^{\dagger}$ is high.

Very low: this research does not provide a reliable indication of the likely effect; the likelihood that the effect will be substantially different ${ }^{\dagger}$ is very high

*This is sometimes referred to as 'quality of evidence' or 'confidence in the estimate'

†Substantially different $=$ a large enough difference that it might affect a decision.

Cl: confidence interval; NR: not reported; VBAC: vaginal birth after caesarean.

aMultifaceted interventions with components targeted at women, healthcare professionals or healthcare organisations. 


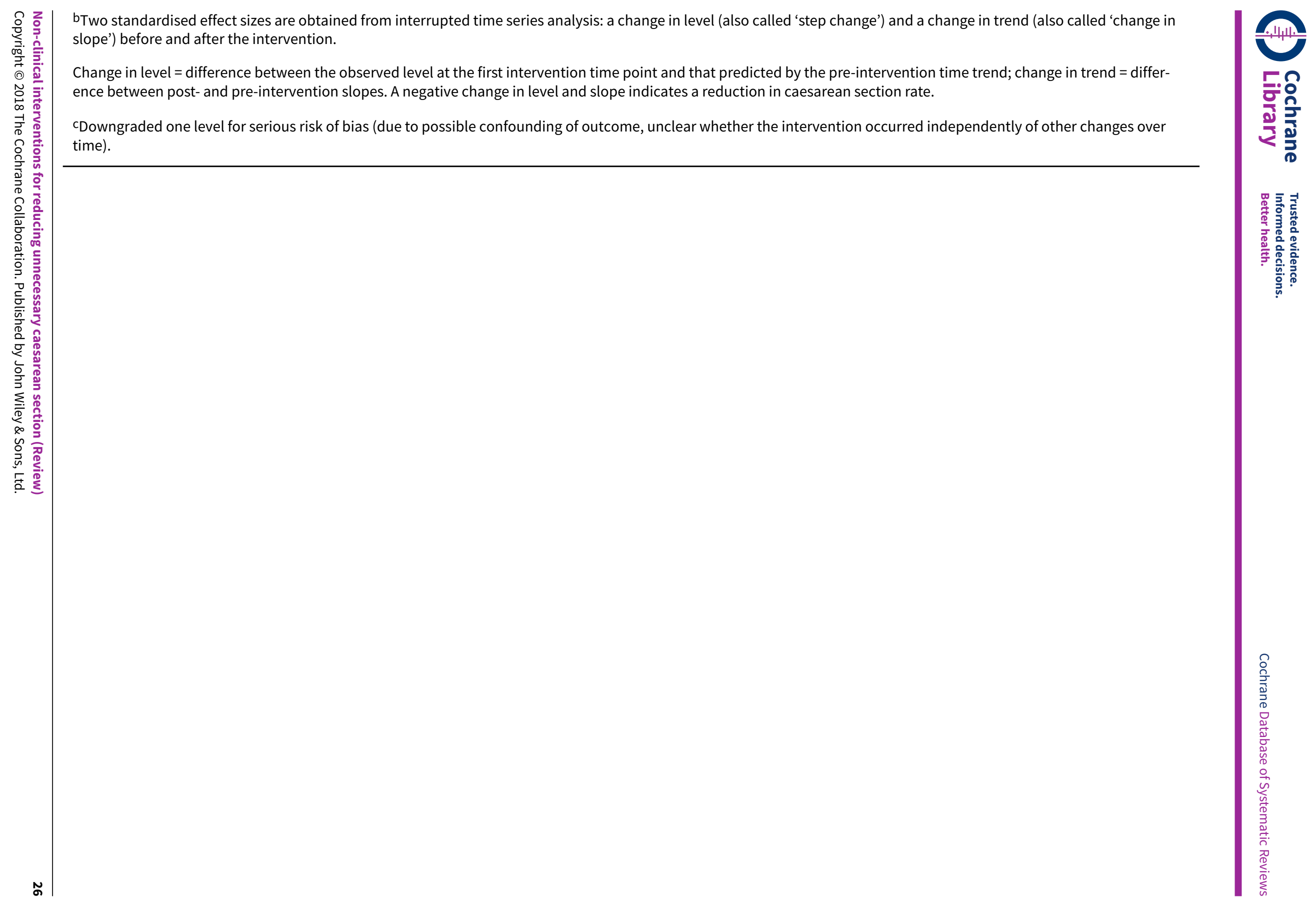




\section{B A C K G R O U N D}

This is the first update of the original review (Khunpradit 2011).

\section{Description of the condition}

Caesarean section is an intervention to reduce complications associated with childbirth. While it can be a life-saving procedure for both the mother and the baby, there is no evidence showing the benefits of caesarean delivery for women or babies who do not require the procedure. As with any surgery, caesarean sections are associated with short- and long-term risks which can extend many years beyond the current delivery and affect the health of the woman, baby and future pregnancies. Maternal risks include infections, haemorrhage, other organ injury, and complications related to use of anaesthesia or blood transfusion (Cook 2013; Marshall 2011). There is also a higher risk of complications in subsequent pregnancies, such as uterine rupture, placental implantation problems and need for hysterectomy (Keag 2018; Timor-Tritsch 2012). Infant risks include respiratory problems, asthma and obesity in childhood (Keag 2018).

Given the balance of risks and benefits, national clinical societies recommend that in the absence of maternal or foetal indications for caesarean section, a plan for vaginal delivery is safe and recommended (ACOG 2013). The National Institute for Health and Care Excellence (NICE) in its 2013 evidence update "recommends that if a woman requests a CS [caesarean section] when there is no other indication; discuss the overall risks and benefits of CS compared with vaginal birth. If necessary, a discussion should be held with other members of the obstetric team (including the obstetrician, midwife and anaesthetist) if necessary to explore the reasons for the request, and ensure the woman has accurate information. If after discussion and offer of support (including perinatal mental health support for women with anxiety about childbirth), a vaginal birth is still not an acceptable option, offer a planned CS." (NICE 2013).

Worldwide, reported caesarean section rates vary widely, especially between high- and low-income countries. However, the rise in caesarean section rates is a global phenomenon. From 1990 to 2014 , the global average caesarean section rate increased threefold from $6.7 \%$ to $19.1 \%$, with an average rate increase of $4.4 \%$ per year. On average, caesarean section rates increased from $22.8 \%$ to $42.2 \%$ in Latin American and the Caribbean, $18.5 \%$ to $32.6 \%$ in Oceania, $22.3 \%$ to $32.3 \%$ in North America, $11.2 \%$ to $25 \%$ in Europe, 4.4\% to $19.5 \%$ in Asia, and $2.9 \%$ to $7.4 \%$ in Africa (Betrán 2016a).

In 1985, the World Health Organization (WHO) issued a consensus statement suggesting there were unlikely to be any additional health benefits associated with caesarean section rates above $10 \%$ to $15 \%$ (WHO 1985). More recently in 2015, the WHO published the results of a systematic review of population-based studies to help determine an ideal caesarean section rate at a population level (Betrán 2016b). Based on this review, the WHO found that while caesarean sections are effective in saving maternal and infant lives and should be provided for medically indicated reasons, caesarean rates greater than $10 \%$ at a population level are not associated with reductions in maternal and newborn mortality. The result of this systematic review was confirmed by a complementary global longitudinal ecological study (Ye 2015).
The factors affecting the rate of caesarean section births are complex, and identifying interventions to reduce this rate is challenging. The decision to perform a caesarean section may be made before conception, earlier in pregnancy or during a perinatal emergency. The decision may be made by a doctor or the mother, and may be affected by a range of other factors. Factors independently associated with caesarean births include: maternal age, body weight (NCC-WCH 2011), women increasingly wanting to determine how and when their child is born (Lo 2003), cultural beliefs about the birthing process that make caesarean sections more or less attractive (Hsu 2008), beliefs about the impact of caesarean section (Dweik 2014), primiparity (Pang 2008), generational shifts in work and family responsibilities (Scioscia 2008), physician and organisational factors (Hoxha 2017; Ji 2015; Lin 2004; Luthy 2003; Mi 2014; Thomas 2001; Zwecker 2011). Indeed, some have argued that simple policy options are unlikely to effectively address the many different factors involved (Scioscia 2008), and that multicomponent interventions that address a range of determinants are desired.

\section{Description of the intervention}

Clinical interventions that could help to reduce caesarean section rates have been assessed in a number of systematic reviews and include: active management in labour (Brown 2013; Catling-Paull 2011b; Hartmann 2012), use of a partogram with a four-hour action line in labour, foetal blood sampling before caesarean section for abnormal cardiotocograph in labour, and support for women who choose vaginal birth after caesarean section (NICE 2013), improved and standardised foetal heart rate interpretation and management, external cephalic version for breech presentation after 36 weeks (NICE 2013), and a trial of labour for women with twin gestations when the first twin is in cephalic presentation (ACOG SMFM 2014). These are clinical decisions and are not included in this review.

This review examines non-clinical interventions (i.e. interventions applied independent of a clinical encounter between a healthcare provider and a patient in the context of patient care) to reduce unnecessary caesarean section rates (i.e. those performed in the absence of medical indications (Kabir 2004; Koroukian 1998)). These interventions may target women (e.g. birth preparation classes), healthcare professionals (e.g. implementation of clinical practice guidelines) or healthcare organisations (e.g. different payment systems for caesarean section) (Table 1).

\section{How the intervention might work}

The different interventions intended to reduce caesarean section births might work by addressing determinants of caesarean births. Table 2 shows examples of interventions targeting healthcare recipients, healthcare professionals, or healthcare organisations that contribute to increasing caesarean section rates.

\section{Why it is important to do this review}

A reliable synthesis of the evidence will help determine the effectiveness and safety of existing interventions that aim to reduce unnecessary caesarean sections, and help decision makers select the most appropriate interventions to implement. In 2011, we found evidence from 16 studies that non-clinical interventions may have a role in reducing unnecessary caesarean sections (Khunpradit 2011). As the prevention of unnecessary caesarean sections continues to be a global priority and the body of evidence continues to increase, an update of this review is warranted to 
provide up-to-date evidence to guide policy and practice decisions to reduce caesarean births. This review update will inform a new WHO guideline, and the scope of the update was informed by WHO's Guideline Development Group for this guideline.

\section{O B J E C T I VES}

To determine the effectiveness and safety of non-clinical interventions intended to reduce unnecessary caesarean section.

\section{METHODS}

\section{Criteria for considering studies for this review}

\section{Types of studies}

The following studies were eligible for inclusion (EPOC 2017).

- Randomised trials.

- Non-randomised trials.

- Controlled before-after studies (with at least two intervention sites and two control sites).

- Interrupted time series studies (where the time of intervention is clearly defined and there are at least three data points before and three after the intervention).

- Repeated measures studies (an interrupted time series study where measurements are made in the same individuals at each time point).

\section{Types of participants}

Studies involving the following groups of participants were eligible for inclusion.

- Pregnant women seeking maternity care during pregnancy, labour and delivery.

- Families of pregnant women.

- Healthcare providers who work with pregnant women (nurses, midwives, physicians).

- Healthcare facilities that provide maternity care to pregnant women.

- Communities and advocacy groups involved in maternity care.

\section{Types of interventions}

Studies involving the following interventions were eligible for inclusion (Table 1).

- Interventions targeted at women, the community or the general public (e.g. birth preparation classes).

- Interventions targeted at healthcare professionals (e.g. implementation of clinical practice guidelines).

- Interventions targeted at healthcare organisations or facilities (e.g. different payment systems for caesarean section).

We compared the interventions above to the following.

- No intervention.

- Usual care or practice in accordance with local protocols.

- Another intervention, as reported in the studies.

In order to avoid duplication, we have not included other related interventions addressed in related reviews: midwifeled continuity of care (Sandall 2016); continuous labour support (Bohren 2017); physical activity-based interventions (iWIP 2017); alternative institutional birth environment (Hodnett 2012); and planned hospital birth versus planned home birth (Olsen 2012). Furthermore, we only included non-clinical interventions specifically designed to reduce caesarean section rates. Interventions not specifically designed to reduce caesarean section rates are not included, even if they may incidentally reduce caesarean section rates.

As noted above, this review update will inform a new WHO guideline, and the scope of the update was informed by WHO's Guideline Development Group for this guideline.

\section{Types of outcome measures}

\section{Primary outcomes}

- Caesarean section

- Spontaneous vaginal birth

- Instrumental vaginal birth

\section{Secondary outcomes}

- Maternal mortality and morbidity

- Neonatal mortality and morbidity

- Maternal birth experience

- Healthcare resource utilisation

Details of the outcome measures are summarised in Table 3. We excluded studies that only reported secondary outcomes without data on primary outcomes.

\section{Search methods for identification of studies}

\section{Electronic searches}

We searched the following databases (Appendix 1):

- The Cochrane Pregnancy and Childbirth Group specialised register (March 2010 to August 2014) (searched August 2014)

- Cochrane Central Register of Controlled Trials (CENTRAL;2018, Issue 2) in the Cochrane Library (searched 8 March 2018)

- MEDLINE Ovid (including Epub Ahead of Print, In-Process \& Other Non-Indexed Citations and Versions) (to 7 March 2018) (searched 8 March 2018)

- EMBASE Ovid (to 7 March 2018) (searched 8 March 2018)

- CINAHL EBSCO (Cumulative Index to Nursing and Allied Health Literature; to 8 March 2018) (searched 8 March 2018)

Search strategies are comprised of keywords and controlled vocabulary terms. We applied no language limits. Searches for this update aimed to retrieve material published since 2010; the date of the searches in the previous version of the review. The search terms were revised to increase specificity by analysing the titles, abstracts and MEDLINE index terms of the included studies from the previous version of the review using various text analysis tools (TerMine; Voyant Tools; Yale MeSH Analyzer).

Prior to the above, we ran updated searches in August 2014 (Appendix 2) and February 2017 (Appendix 3). The February 2017 searches were supplementary searches run in MEDLINE and Embase for interventions relating to environmental modifications (i.e. physical or sensory environment of labour or delivery room), organisational goals (i.e. setting predetermined caesarean 
section rates) and organisational change (i.e. strategies to change organisational culture).

\section{Searching other resources}

\section{Grey literature}

Since the Cochrane Pregnancy and Childbirth Group Specialised Register includes extensive handsearching of journals and conference proceedings, we did not perform additional handsearching of journals or conference proceedings. We searched reference lists of trials and related reviews, websites of relevant organisations, and contacted authors for additional articles.

\section{Trials registries}

We searched the following two clinical trials registries for ongoing trials or completed trials that have not been published on 8 March 2018:

- International Clinical Trials Registry Platform (ICTRP), Word Health Organization (WHO) (www.who.int/ictrp/en/).

- ClinicalTrials.gov, US National Institutes of Health (NIH) (clinicaltrials.gov/).

\section{Data collection and analysis}

\section{Selection of studies}

We entered the identified records into Covidence after removing duplicates (www.covidence.org). Seven review authors, working in pairs, independently screened titles, abstracts and full texts of identified records and selected studies meeting review inclusion criteria. We resolved disagreements by discussion.

\section{Data extraction and management}

Five review authors, working in pairs, independently extracted data on the following aspects from the included studies. We entered data into a pilot-tested data extraction form. We resolved disagreements by discussion.

- Study design and unit of allocation.

- Study setting (e.g. community, hospital, single or multicentre).

- Participants (e.g. parity, gestational age).

- Intervention and control (e.g. duration and frequency of training).

- Outcome measures (e.g. caesarean section).

\section{Assessment of risk of bias in included studies}

Five review authors, working in pairs, independently assessed study risk of bias using the Cochrane EPOC 'Risk of bias' criteria for randomised trials, non-randomised trials, controlled beforeafter studies and interrupted time series studies (EPOC 2017). We classified findings into three categories: low - low risk of bias for key quality domains; high - high risk of bias for one or more of the key domains; or unclear - unclear risk of bias for one or more of the key domains. We resolved disagreements by discussion.

\section{Measures of treatment effect}

For dichotomous outcomes, we assessed the effect of interventions using risk ratios (RRs), odds ratios (ORs) or risk differences (RDs). We used the mean difference (MD) measure for continuous outcomes. For interrupted time series studies, we used two effect sizes to measure the intervention effect: change in level (also called 'step change') and change in trend (also called 'change in slope') before and after the intervention (Bernal 2017). Change in level is the difference between the observed level at the first intervention time point and that predicted by the pre-intervention time trend; change in trend is the difference between post- and pre-intervention slopes. A negative change in level and slope indicates a reduction in the event. Where these effect measures were not estimable (e.g. owing to insufficient data), we reported results in natural units as reported in the studies.

\section{Unit of analysis issues}

We checked whether appropriate analysis was conducted to adjust for clustering in cluster-randomised trials. If there was a unit of analysis error and reanalysis was not possible, we reported only the point estimate without a measure of variance (such as confidence intervals $(\mathrm{Cls}))$.

Three of the included studies had three arms and therefore contributed multiple comparisons (Lomas 1991; Montgomery 2007; Valiani 2014). A unit of analysis error did not arise from these studies as we did not pool effect estimates from the studies.

\section{Dealing with missing data}

We contacted authors of included studies where needed data were missing, or where we required further clarification on the reported data. Where data were not available from the authors, we reported the data as missing and analysed only the available data. We did not impute or extrapolate values for missing data.

\section{Assessment of heterogeneity}

We did not conduct statistical tests for heterogeneity (differences in study designs and interventions precluded meta-analysis).

\section{Assessment of reporting biases}

We assessed potential reporting bias due to selective outcome reporting as one component of 'Risk of bias' assessment. In addition, we checked whether prespecified outcomes were reported, based on the information provided in trials registry records or protocols, where these were available.

\section{Data synthesis}

We grouped interventions into four categories and prepared evidence tables for each category.

- Interventions targeted at women or families (Table 4; Table 5).

- Interventions targeted at healthcare professionals (Table 6; Table 7).

- Interventions targeted at healthcare organisations or facilities (Table 8; Table 9).

- 'Cross-cutting' interventions (i.e. multifaceted interventions with components targeted at women, healthcare professionals or healthcare organisations) (Table 10; Table 11).

\section{GRADE and summary of findings}

We assessed the certainty of evidence (confidence in the estimate of effect) using GRADE (Guyatt 2008). The GRADE assessments were conducted by one review author (NO) and checked by at least one other review author. 
According to GRADE, evidence from randomised trials starts at high certainty while that from observational studies starts at low certainty. We downgraded certainty of evidence from randomised trials in consideration of five factors: risk of bias or study limitations, directness, consistency of results, precision of effect estimates and publication bias. Quality of evidence from observational studies can be upgraded in consideration of three factors: magnitude of effect, dose-response gradient and influence of residual plausible confounding. We did not upgrade the quality of evidence from any of the included observational studies as none met the upgrading criteria.

We prepared four 'Summary of findings' tables (one each for the four intervention categories) summarising effects of the interventions on the primary outcome measures (caesarean section, spontaneous vaginal birth, and instrumental vaginal birth) and adverse effects (maternal and neonatal mortality or morbidity).

\section{Subgroup analysis and investigation of heterogeneity}

We did not conduct a subgroup analysis to explore if effects of interventions varied by factors such as parity, socioeconomic status or geographical regions (there was insufficient data for these analyses).

\section{Sensitivity analysis}

We did not conduct a sensitivity analysis as we did not pooled the data.

\section{RE S U L T S}

\section{Description of studies}

\section{Results of the search}

Details of the search results are presented in Figure 1. We identified 12,155 records from electronic databases, clinical trials registries and other resources. We excluded 12,015 records following a review of titles and abstracts. We retrieved the full texts of the remaining 140 records for detailed eligibility assessment. We excluded 113 records; two studies are awaiting classification and will be considered for inclusion in the next update of this review (Characteristics of studies awaiting classification), and eight trials are ongoing (Characteristics of ongoing studies).

Figure 1. aSearches run in March 2018 (Appendix 1). bSearches run in August 2014 (Appendix 2) and February 2017 (Appendix 3).

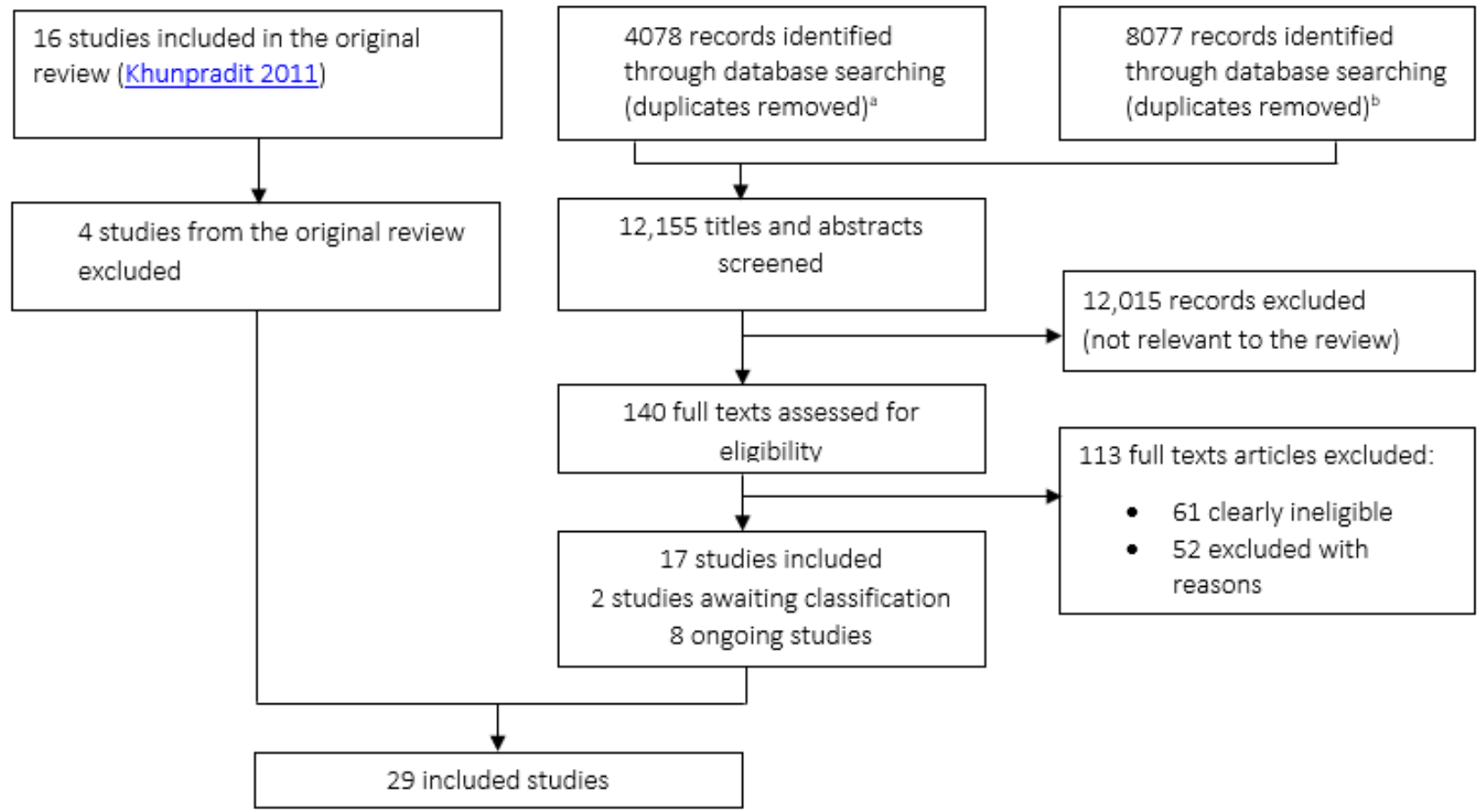

Overall, 29 studies fulfilled the review inclusion criteria (17 new studies and 12 studies from the original review (Khunpradit 2011)).

\section{Included studies}

The 29 included studies form the basis of the findings summarised in this review (Characteristics of included studies).

These studies were conducted in 18 different countries.

- North America (7 studies in USA; 2 studies in Canada).
- Europe (3 studies in Finland; 1 study each in UK, Portugal, Sweden)

- Latin America (1 study in Chile; 1 multicentre study in Argentina, Brazil, Cuba, Guatemala, Mexico).

- Western Asia (6 studies in Iran).

- East Asia (2 studies in China; 2 studies in Taiwan).

- Oceania (2 studies in Australia).

Caesarean section rates in the control groups (or prior to intervention in other study designs) ranged from $12 \%$ in Hemminki 2008 to $73.3 \%$ in Valiani 2014. 
Eight studies included only nulliparous women (Bastani 2006; Bergstrom 2009; Feinberg 2015; Navaee 2015; Rouhe 2013; Sharifirad 2013; Valiani 2014; Wang 2014). Five studies included only women having undergone a previous caesarean section (Eden 2014; Fraser 1997; Lomas 1991; Montgomery 2007; Shorten 2005); the remaining 16 studies included a mixed population of women.

Twenty-three studies were supported by grants from various funding agencies (international funding agencies, national research councils, universities, among others); two studies received no specific financial support. No information about funding was available from four studies.

\section{Interventions targeted at women or families}

Fifteen studies (4459 participants) were included in this category: 12 studies compared specific educational interventions to routine maternity care (Bastani 2006; Bergstrom 2009; Feinberg 2015; Fenwick 2015; Masoumi 2016; Montgomery 2007; Rouhe 2013; Saisto 2001; Sharifirad 2013; Shorten 2005; Valiani 2014; Wang 2014). Three studies compared different formats of educational interventions (Eden 2014; Fraser 1997; Navaee 2015). All of the studies were randomised trials.

Participants in the included studies comprised: women with a fear of childbirth (Fenwick 2015; Navaee 2015; Rouhe 2013; Saisto 2001); women with high levels of anxiety (Bastani 2006); husbands of pregnant women (Sharifirad 2013); pregnant women and couples (Valiani 2014); and pregnant women with no particular health condition in the remaining studies.

The majority of studies were conducted in high-income countries: USA (Eden 2014; Feinberg 2015; Fraser 1997); UK (Montgomery 2007); Australia (Fenwick 2015; Shorten 2005); Canada (Fraser 1997); Sweden (Bergstrom 2009); and Finland (Rouhe 2013; Saisto 2001). Six studies were conducted in middle-income countries: China (Wang 2014); Iran (Bastani 2006; Masoumi 2016; Navaee 2015; Sharifirad 2013; Valiani 2014). No studies were carried out in lowincome countries.

The specific educational interventions assessed were the following.

- Antenatal education programme for physiologic childbirth (birth preparation training) (Masoumi 2016).

- Antenatal education on natural childbirth preparation with training in breathing and relaxation techniques (Bergstrom 2009).

- Childbirth training workshop (Valiani 2014)

- Prenatal education for husbands of pregnant women (Sharifirad 2013).

- Pelvic floor muscle training exercises with telephone follow-up (Wang 2014).

- Nurse-led applied relaxation training programme (Bastani 2006).

- Psychosocial couple-based prevention programme (Feinberg 2015).

- Psychoeducation by telephone (Fenwick 2015).

- Psychoeducation (Rouhe 2013).

- Two computer-based decision aids (information programme, decision analysis) (Montgomery 2007).

- Intensive group therapy (cognitive behavioural therapy and childbirth psychotherapy) (Saisto 2001).
- Decision aid booklet (Shorten 2005).

Women in the control group received routine maternity care. Pelvic floor muscle training with telephone follow-up was compared to Pelvic floor muscle training without telephone follow-up.

The different formats of educational interventions assessed were the following.

- Role play education versus standard education using lectures (Navaee 2015).

- Interactive decision aid versus educational brochures (Eden 2014).

- Individualised prenatal education and support programme versus written information in pamphlets (Fraser 1997).

Details of the interventions are summarised in Table 4.

\section{Interventions targeted at healthcare professionals}

We included eight studies in this category (Althabe 2004; Chaillet 2015; Hemminki 2008; Liang 2004; Lomas 1991; Mohammadi 2012; Poma 1998; Scarella 2011). Study designs were varied: cluster-randomised trials (Althabe 2004; Chaillet 2015; Hemminki 2008; Lomas 1991); controlled before-after studies (reanalysed using interrupted time series methods) (Mohammadi 2012); and interrupted time series studies (Liang 2004; Poma 1998; Scarella 2011).

Six studies were conducted in high-income countries: USA (Poma 1998); Canada (Chaillet 2015; Lomas 1991); Finland (Hemminki 2008); Chile (Scarella 2011); and Taiwan (Liang 2004). Two studies were conducted in middle-income countries: Iran (Mohammadi 2012); multicountry - Mexico, Argentina, Brazil, Cuba, Guatemala and Mexico (Althabe 2004). No studies were carried out in lowincome countries.

Health professionals studied were: physicians (obstetriciangynaecologist) (Althabe 2004; Liang 2004; Lomas 1991; Mohammadi 2012; Poma 1998); physicians and nurses (Chaillet 2015; Scarella 2011); and public health nurses (Hemminki 2008).

The interventions assessed were the following.

- Education of public health nurses on childbirth classes (Hemminki 2008).

- Peer review plus mandatory second opinion (Liang 2004).

- Evidence-based guidelines plus mandatory second opinion (Althabe 2004).

- Evidence-based guidelines plus audit and feedback (Chaillet 2015).

- Audit and feedback using Robson classification (Scarella 2011).

- Audit and feedback plus financial incentive (Mohammadi 2012).

- Audit and feedback plus 24-hour in-house physician coverage (Poma 1998).

- Audit and feedback plus local opinion leader education (Lomas 1991).

Details of the interventions are summarised in Table 6 . 


\section{Interventions targeted at healthcare organisations or facilities}

\subsection{Financial interventions targeted at healthcare professionals}

We included two interrupted time series studies in this category (Keeler 1996; Lo 2008). The studies were conducted in the USA (Keeler 1996), and Taiwan (Lo 2008). Both assessed insurance reforms equalising physician fees for vaginal births and caesarean sections. Details of the interventions are summarised in Table 8.

\subsection{Different staffing models of care}

We included two studies in this category. The interventions assessed were the following.

- Labourist model of obstetric care versus routine delivery care (Srinivas 2016). ('Labourist' generally refers to an obstetrician who provides in-house labour and delivery coverage without competing clinical duties).

- Midwifery-labourist model of care versus private practice care model (Rosenstein 2015).

Details of the interventions are summarised in Table 8.

Study designs were varied: controlled before-after study (Srinivas 2016); interrupted time series study (Rosenstein 2015). Both studies were conducted in the USA.

\section{4. 'Cross-cutting' interventions}

We included the following two interventions in this category.

- Multifaceted programme comprising an education programme for hospital staff and women, audit of surgeon practices, public health campaign, monitoring rates of caesarean section and neonatal outcomes (Runmei 2012).

- Multifaceted programme comprising transmission of information on caesarean section to health professionals, training of health workers on best obstetric practices and inclusion of caesarean section rates as a criterion for hospital funding (Ayres-De-Campos 2015).

Details of the interventions are summarised in Table 10.

Study design and settings were varied: interrupted time series study (Ayres-De-Campos 2015); controlled before-after study (Runme 2012). Ayres-De-Campos 2015 was conducted in Portugal, while Runmei 2012 was conducted in China.

\section{Excluded studies}

We excluded 52 studies because of ineligible study designs, interventions and outcome measures (see Characteristics of excluded studies).

\section{Risk of bias in included studies}

Randomised trials, non-randomised trials and controlled before-after studies ( 20 studies)

\section{Allocation}

We judged random sequence generation and allocation concealment to be adequate (indicating low risk of selection bias) in eight trials (Althabe 2004; Chaillet 2015; Eden 2014; Fenwick 2015; Fraser 1997; Masoumi 2016; Montgomery 2007; Shorten 2005). We judged Srinivas 2016 to be at high risk of selection bias. The risk of selection bias in the remaining trials was unclear (insufficient information was available regarding allocation concealment).

\section{Blinding}

We judged blinding of study participants and personnel to be adequate (indicating low risk of performance bias) in four trials (Althabe 2004; Chaillet 2015; Eden 2014; Fenwick 2015). The risk of performance bias was unclear in the remaining trials. Blinding of primary outcome measures was not feasible (caesarean and vaginal births are objective outcomes).

\section{Incomplete outcome data}

We judged the risk of attrition bias (due to incomplete outcome data) to be low in 14 trials, high in one trial (Hemminki 2008), and unclear in five trials (Feinberg 2015; Lomas 1991; Navaee 2015; Valiani 2014; Wang 2014).

\section{Selective reporting}

We judged all trials to be at low risk of reporting bias (due to selective reporting), except in one trial (Hemminki 2008), where the likelihood of reporting bias was unclear.

\section{Other potential sources of bias}

We judged three trials to be at risk of other biases due to unit of analysis issues (Bergstrom 2009; Lomas 1991), and lack of a priori sample size calculation (Hemminki 2008).

Details of the risk of bias judgements are summarised in Characteristics of included studies and Figure 2. 
Figure 2. Risk of bias summary: review authors' judgements about each risk of bias item for each included study.

\begin{tabular}{|c|c|c|c|c|c|c|c|c|c|c|c|c|c|c|}
\hline & 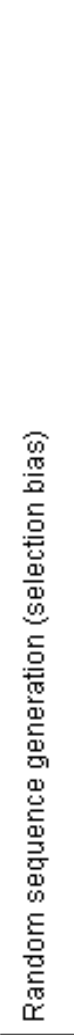 & 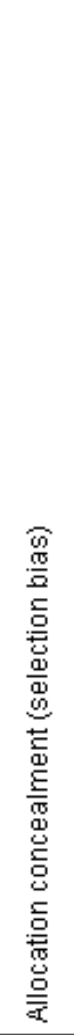 & 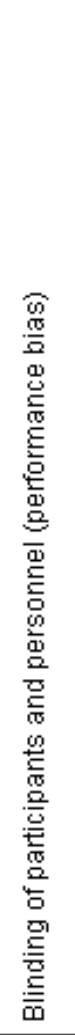 & 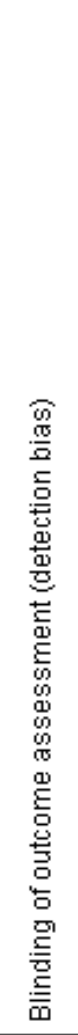 & 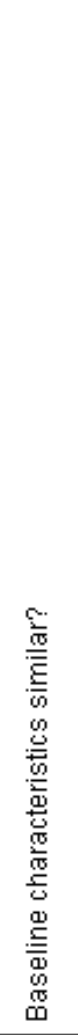 & 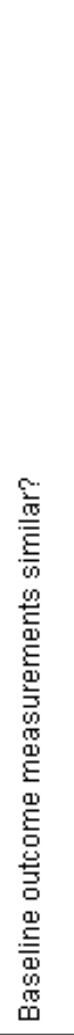 & 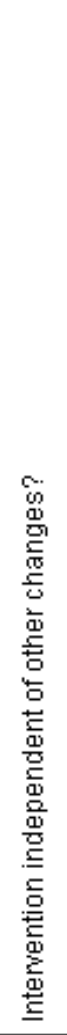 & 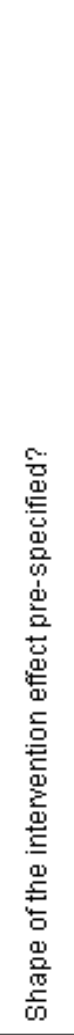 & 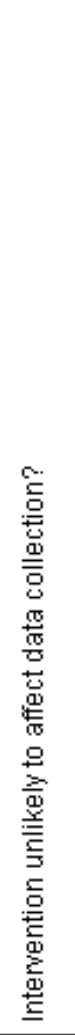 & 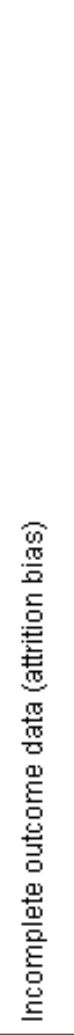 & 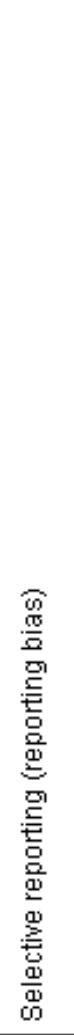 & 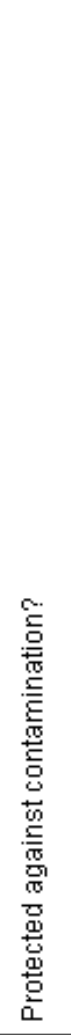 & 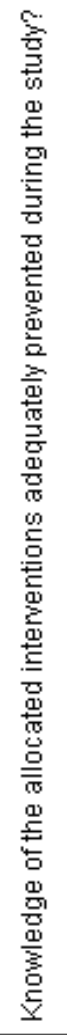 & 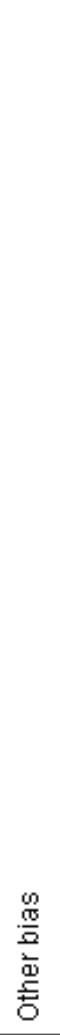 \\
\hline Althabe 2004 & + & + & + & $\odot$ & $\odot$ & $\oplus$ & & & & + & + & + & & $\odot$ \\
\hline Ayres-De-Campos 2015 & & & & & & & $\Theta$ & - & $\odot$ & $?$ & $\odot$ & & $\odot$ & $\odot$ \\
\hline Bastani 2006 & $?$ & $?$ & $?$ & $\odot$ & + & $\odot$ & & & & $\odot$ & $\odot$ & $?$ & & $\odot$ \\
\hline Bergstrom 2009 & $\odot$ & $?$ & $?$ & $?$ & $\odot$ & $?$ & & & & $\odot$ & + & $\odot$ & & $\odot$ \\
\hline Chaillet 2015 & $\odot$ & $\odot$ & $\odot$ & $\odot$ & $\odot$ & $\odot$ & & & & $\odot$ & $\odot$ & $\odot$ & & $\odot$ \\
\hline Eden 2014 & $\odot$ & 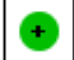 & $\odot$ & 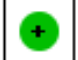 & + & $?$ & & & & $\odot$ & + & $?$ & & $\odot$ \\
\hline Feinberg 2015 & $?$ & $?$ & $?$ & $?$ & $\odot$ & $?$ & & & & $?$ & $\odot$ & $?$ & & $\oplus$ \\
\hline Fenwick 2015 & $\odot$ & + & $\odot$ & + & + & $?$ & & & & $\odot$ & + & $\oplus$ & & $\odot$ \\
\hline Fraser 1997 & + & + & $?$ & 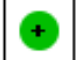 & + & $\oplus$ & & & & + & + & $?$ & & $\odot$ \\
\hline Hemminki 2008 & + & $?$ & $?$ & + & + & $?$ & & & & $\odot$ & $?$ & + & & $\odot$ \\
\hline Keeler 1996 & & & & & & & $?$ & + & $?$ & $?$ & + & & $\odot$ & $\odot$ \\
\hline Liang 2004 & & & & & & & $?$ & + & + & $?$ & + & & + & $\odot$ \\
\hline Lo 2008 & & & & & & & $?$ & 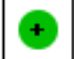 & + & $?$ & + & & $\odot$ & $\oplus$ \\
\hline Lomas 1991 & $?$ & $?$ & $?$ & $\odot$ & + & $\odot$ & & & & $?$ & + & $\odot$ & & $\odot$ \\
\hline Masoumi 2016 & + & + & $?$ & $\odot$ & + & $\odot$ & & & & + & + & $?$ & & $\odot$ \\
\hline Mohammadi 2012 & & & & & & & $?$ & + & $\odot$ & $?$ & $\odot$ & & $\odot$ & $\odot$ \\
\hline
\end{tabular}


Figure 2. (Continued)

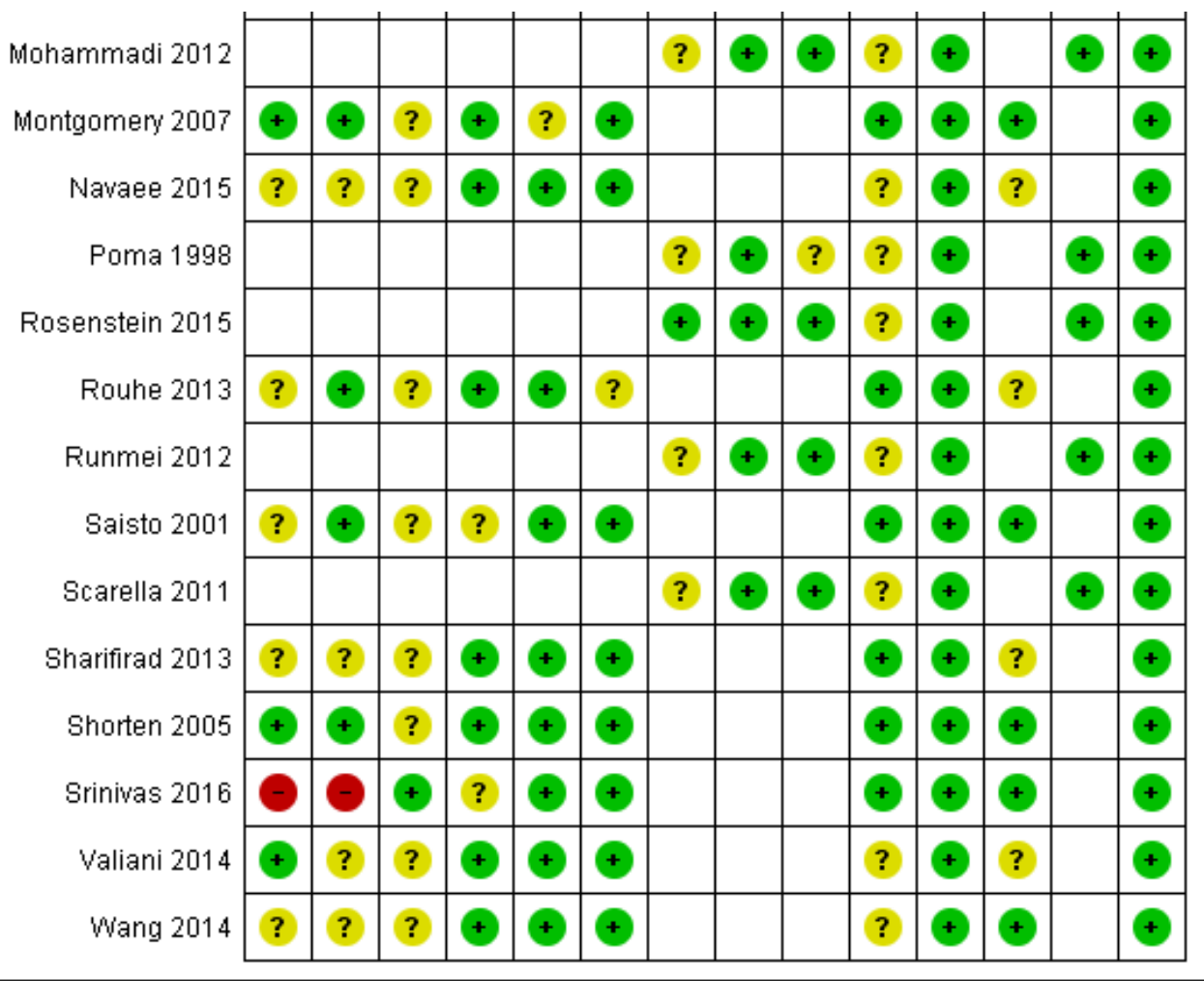

\section{Interrupted time series studies (9 studies)}

We judged all of the interrupted time series studies to be at unclear risk of attrition bias and free of reporting bias. The shape of the intervention effect was prespecified in all except two studies (Ayres-De-Campos 2015; Poma 1998). It was not clear if the intervention was independent of other changes in all except one study (Rosenstein 2015). The intervention seemed unlikely to affect data collection in all except two studies (Keeler 1996; Poma 1998). We considered knowledge of the allocated interventions to be adequately prevented in all studies (main outcomes of interests are objective). We judged one study to be at high risk of other bias (due to inadequate analysis) (Keeler 1996).

Details of the risk of bias judgements are summarised in Characteristics of included studies and Figure 2.

\section{Effects of interventions}

See: Summary of findings for the main comparison Interventions targeted at women or families; Summary of findings 2 Interventions targeted at healthcare professionals; Summary of findings $\mathbf{3}$ Interventions targeted at healthcare organisations or facilities; Summary of findings 4 'Cross-cutting' interventionsa

\section{Interventions targeted at women or families}

See: Summary of findings for the main comparison

\subsection{Education, birth preparation classes and support programmes}

Data from three of the 15 studies included in this category, suggest that the following interventions may reduce caesarean section rates.
- Childbirth training workshop (mothers alone versus control: risk ratio (RR) $0.55,95 \%$ confidence interval (CI) 0.33 to 0.89 ; 60 participants, low-certainty evidence); (couple versus control: RR $0.59,95 \% \mathrm{Cl} 0.37$ to $0.94 ; 60$ participants, low-certainty evidence; Valiani 2014, randomised trial).

- Nurse-led applied relaxation training programme (RR 0.22, 95\% $\mathrm{Cl} 0.11$ to $0.43 ; 104$ participants, low-certainty evidence; Bastani 2006, randomised trial).

- Psychosocial couple-based prevention programme (RR 0.53, $95 \% \mathrm{Cl} 0.32$ to 0.90 , reanalysed; 147 participants, low-certainty evidence; Feinberg 2015, randomised trial).

Data from two studies suggest that the following two interventions may increase rates of vaginal births.

- Childbirth training workshop (mothers alone versus control: RR 2.25, $95 \% \mathrm{Cl} 1.16$ to 4.36 ; 60 participants, low-certainty evidence); (couple versus control: RR 2.13, 95\% Cl 1.09 to 4.16; 60 participants, low-certainty evidence; Valiani 2014, randomised trial).

- Psychoeducation (RR 1.33, 95\% Cl 1.11 to $1.61 ; 371$ participants, low-certainty evidence; Rouhe 2013, randomised trial).

Limited data were available on the effect of the four interventions on maternal and neonatal mortality or morbidity.

There was little or no difference in caesarean section rates between standard maternity care and the following seven interventions.

- Antenatal education programme for physiologic childbirth (RR $1.03,95 \% \mathrm{Cl} 0.72$ to $1.49 ; 150$ participants, moderate-certainty evidence; Masoumi 2016, randomised trial). 
- Pelvic floor muscle training exercises with telephone follow-up versus pelvic floor muscle training exercises without telephone follow-up (RR $0.87,95 \% \mathrm{Cl} 0.37$ to 2.04 ; 90 participants, lowcertainty evidence; Wang 2014, randomised trial).

- Antenatal education on natural childbirth preparation with training in breathing and relaxation techniques:

* elective caesarean section: RR $0.95,95 \% \mathrm{Cl} 0.58$ to $1.56 ; 977$ participants, moderate-certainty evidence;

* emergency caesarean section: RR $0.91,95 \% \mathrm{Cl} 0.67$ to 1.23 ; 977 participants, moderate-certainty evidence (Bergstrom 2009, randomised trial).

- Psychoeducation (RR 0.70, 95\% Cl 0.49 to $1.01 ; 371$ participants, low-certainty evidence; Rouhe 2013, randomised trial).

- Computer-based decision aids (information programme, decision analysis):

* information group versus usual care group, elective caesarean section: RR $0.98,95 \% \mathrm{Cl} 0.82$ to $1.18,478$ participants, moderate-certainty evidence;

* information group versus usual care group, emergency caesarean section: RR $1.09,95 \% \mathrm{Cl} 0.77$ to $1.55,478$ participants, moderate-certainty evidence;

* decision analysis group versus usual care group, elective caesarean section: RR $0.83,95 \% \mathrm{Cl} 0.68$ to $1.02,478$ participants, moderate-certainty evidence;

* decision analysis group versus usual care group, emergency caesarean section: RR $1.05,95 \% \mathrm{Cl} 0.74$ to $1.50,478$ participants, moderate-certainty evidence (Montgomery 2007, randomised trial).

- Decision aid booklet (absolute change from baseline $26.2 \%$ versus control 22.6\%; 227 participants, moderate-certainty evidence; Shorten 2005, randomised trial).

- Intensive group therapy (cognitive behavioural therapy and childbirth psychotherapy): RR $0.90,95 \% \mathrm{Cl} 0.65$ to $1.24 ; 176$ participants, low-certainty evidence (Saisto 2001, randomised trial).

The effect of psychoeducation sessions by telephone (Fenwick 2015, randomised trial), and prenatal education for husbands of pregnant women on caesarean section rates is uncertain (very lowcertainty evidence) (Sharifirad 2013, randomised trial).

Details of the effect estimates and GRADE certainty ratings are summarised in Table 5.

\subsection{Different formats of educational interventions}

Data from three studies assessing different formats of educational interventions showed little or no differences in rates of caesarean section or vaginal birth after caesarean between formats.

- Role play versus standard education using lectures (caesarean section: RR $0.66,95 \% \mathrm{Cl} 0.39$ to $1.12 ; 67$ participants, lowcertainty evidence; Navaee 2015, randomised trial).

- Interactive decision aid versus educational brochures (vaginal birth after caesarean: $41 \%$ versus 37\%; number of participants unclear, low-certainty evidence; Eden 2014, randomised trial).

- Individualised prenatal education and support programme versus written information in pamphlet (caesarean section: RR $0.92,95 \% \mathrm{Cl} 0.82$ to 1.03 ); (vaginal birth after caesarean, RR $1.08,95 \% \mathrm{Cl} 0.97$ to $1.21 ; 1275$ participants, moderate-certainty evidence; Fraser 1997, randomised trial).
Maternal and neonatal mortality or morbidity, where reported, were similar between study groups.

Details of the effect estimates and GRADE certainty ratings are summarised in Table 5.

\section{Interventions targeted at healthcare professionals}

See: Summary of findings 2

Among the eight interventions targeted at healthcare professionals, we found two that slightly reduced caesarean section rates (Althabe 2004; Chaillet 2015) and one that reduced caesarean section rate (Lomas 1991).

- Implementation of clinical guidelines combined with mandatory second opinion for caesarean section indication versus routine maternity care (overall caesarean section, mean difference in rate change $-1.9,95 \% \mathrm{Cl}-3.8$ to -0.1 ; high-certainty evidence; Althabe 2004, cluster-randomised trial).

- Implementation of clinical guidelines combined with audit and feedback versus routine maternity care (overall caesarean section, risk difference (RD) $-1.8 \%, 95 \% \mathrm{Cl}-3.8$ to -0.2 ; highcertainty evidence; Chaillet 2015, cluster-randomised trial).

- Physician education by local opinion leader versus routine maternity care (elective caesarean section, opinion leader education: $53.7 \%, 95 \% \mathrm{Cl} 46.5$ to $61.0 \%$; control: $66.8 \%, 95 \%$ $\mathrm{Cl} 61.7$ to $72.0 \%$; high-certainty evidence; Lomas 1991, clusterrandomised trial).

There was little or no difference in maternal and neonatal mortality or morbidity between study groups, where reported, in the three studies (Table 7).

An economic evaluation of a multifaceted intervention implemented by Chaillet and colleagues showed that the intervention group experienced per-patient reductions of 0.005 caesarean sections $(95 \% \mathrm{Cl}-0.015$ to $0.004, \mathrm{P}=0.09)$, which translated to CAD 180 (95\% Cl -277 to $-83, \mathrm{P}<0.001$; Chaillet 2015). The intervention was "dominant" (effective in reducing caesarean section rates and less costly than usual care) in $86.08 \%$ of simulations. It reduced costs in $99.99 \%$ of simulations. Cost reductions were driven by lower rates of neonatal complications in the intervention group (CAD $-190,95 \% \mathrm{Cl}-255$ to $-125, \mathrm{P}<0.001$ ). The authors estimated that given 88,000 annual provincial births, a similar intervention could save CAD 15.8 million (range: 7.3 to 24.4 million) in Quebec annually (Johri 2017, economic evaluation of Chaillet 2015). Further prospective analysis to measure the budget impact of the multifaceted intervention showed that it led to savings of CAD 27 million in Quebec over four years, and that in the short to medium term, extending the intervention nationwide could lead to savings of CAD 150.5 million (Bermúdez-Tamayo 2018, economic evaluation of Chaillet 2015).

There was little or no difference in caesarean section rates between the following two interventions and control.

- Education of public health nurses on childbirth classes (odds ratio (OR) $1.29,95 \% \mathrm{Cl} 0.99$ to $1.67 ; 1568$ participants, Lowcertainty evidence; Hemminki 2008, cluster-randomised trial). 
- Audit and feedback and local opinion leader education:

* elective caesarean section, audit and feedback: $69.7 \%, 95 \%$ $\mathrm{Cl} 62.4$ to 77.0 ;

* unscheduled caesarean section, audit and feedback: $18.6 \%$, $95 \% \mathrm{Cl} 13.9$ to 23.2 ;

* opinion leader education: $21.4 \%, 95 \% \mathrm{Cl} 16.8$ to 26.1 ; control: $18.7 \%, 95 \% \mathrm{Cl} 15.4$ to 22.1 ; high-certainty evidence (Lomas 1991, cluster-randomised trial).

The effect of the following interventions on caesarean section rates is uncertain (very low-certainty evidence).

- Peer review plus mandatory second opinion (Liang 2004, interrupted time series study).

- Audit and feedback using the Robson classification (Scarella 2011, interrupted time series study).

- Audit and feedback plus a financial incentive (Mohammadi 2012, controlled before-after studies (reanalysed using interrupted time series methods)).

- Audit and feedback plus 24-hour in-house coverage by a dedicated physician (Poma 1998, interrupted time series study).

Details of the effect estimates and GRADE certainty ratings are summarised in Table 7.

\section{Interventions targeted at healthcare organisations or facilities}

See: Summary of findings 3

\subsection{Financial interventions targeted at healthcare professionals}

Two studies involving insurance reforms equalising physician fees for vaginal births and caesarean sections were included in this category. The effect of these strategies on caesarean section rates is uncertain (very low-certainty evidence) (Keeler 1996; Lo 2008, both interrupted time series studies). Maternal and neonatal mortality or morbidity were not reported.

Details of the effect estimates and GRADE certainty ratings are summarised in Table 9.

\subsection{Different staffing models of delivery care}

The collaborative midwifery-labourist model of care (in which the obstetrician provides in-house labour and delivery coverage, 24 hours a day, without competing clinical duties) may reduce caesarean section rates, and may increase rates of vaginal birth after caesarean section, compared to the private model of care (Rosenstein 2015, interrupted time series study).

- The primary caesarean section rate among privately insured women decreased from $31.7 \%$ to $25.0 \%$ (OR $0.56,95 \% \mathrm{Cl}$ 0.39 to 0.81 ). The interrupted time series analysis estimated a $7 \%$ drop in the primary caesarean rate in the year after the intervention, and a decrease of $1.7 \%$ per year thereafter (lowcertainty evidence)

- The rate of vaginal births after caesarean section increased from $13.3 \%$ before to $22.4 \%$ after the intervention (OR 2.03, $95 \% \mathrm{Cl}$ 1.08 to 3.80 ; low-certainty evidence).

Maternal and neonatal mortality or morbidity were not reported.
The labourist model of obstetric care, compared to routine delivery care, may lead to little or no difference in the following outcomes (Srinivas 2016, controlled before-after study).

- Caesarean section (OR 1.02, 95\% Cl 0.97 to 1.1; low-certainty evidence).

- Maternal morbidity (chorioamnionitis) (OR 1.07, 95\% $\mathrm{Cl} 0.88$ to 1.30; low-certainty evidence).

- Neonatal morbidity (birth asphyxia) (OR $0.75,95 \% \mathrm{Cl} 0.48$ to 1.18; low-certainty evidence).

Maternal and neonatal mortality were not reported.

Details of the effect estimates and GRADE certainty ratings are summarised in Table 9.

\section{4. 'Cross-cutting' interventions}

See: Summary of findings 4

The effect of the following two multifaceted interventions on caesarean section rate and maternal and neonatal morbidity is uncertain (the certainty of available evidence is very low).

- Programme comprising education for hospital staff and women, audit of surgeon practices, public health campaign, monitoring rates of caesarean sections and neonatal outcomes (Runmei 2012, controlled before-after study).

- Programme comprising transmission of information on caesarean section, training of healthcare workers on best obstetric practices and inclusion of caesarean section rates as a criterion for hospital funding (Ayres-De-Campos 2015, interrupted time series study).

Maternal or neonatal mortality were not reported in either studies. Details of effect estimates and GRADE certainty ratings are summarised in Table 11.

\section{DISCUSSION}

\section{Summary of main results}

This review examined evidence from 29 studies assessing the effectiveness and safety of non-clinical interventions intended to reduce caesarean section births. The studies assessed a range of interventions, targeting various stakeholders (women, families, healthcare professionals and healthcare organisations or facilities), mostly in high-income countries. The summarised evidence is drawn from single studies assessing distinct interventions. Limited data were available on maternal and neonatal mortality and morbidity.

Overall, we found eight interventions to have a beneficial effect on at least one primary outcome measure with low-, moderateor high-certainty evidence, and no moderate- or high-certainty evidence of adverse effects: childbirth training workshop; nurseled applied relaxation training programme; psychosocial couplebased prevention programme; psychoeducation; implementation of clinical practice guidelines combined with mandatory second opinion for caesarean section indication; implementation of clinical practice guidelines combined with audit and feedback; physician education by local opinion leader (obstetriciangynaecologist); and collaborative midwifery-labourist model of care. 
The review targeted settings with high rates of caesarean section rates, where large numbers of caesarean births are assumed to be unnecessary. However, the proportion of unnecessary caesarean sections was not reported in the included studies and it is unclear whether the observed changes in caesarean section rates occurred exclusively in those considered unnecessary. Given this uncertainty, caution should be exercised when interpreting the findings of this review.

\section{Overall completeness and applicability of evidence}

The summarised evidence is derived from a mixed population of pregnant women (nulliparous women, multiparous women, women with a fear of childbirth, women with high levels of anxiety, women having undergone a previous caesarean section, couples, husbands of pregnant women, and pregnant women with no particular health condition).

We did not identify any eligible studies that addressed five prespecified interventions: public dissemination of caesarean section rates; goal-setting for caesarean section rates; policies that limit financial or legal liability in case of litigation of healthcare professionals or organisations; changing the physical or sensory environment of labour and delivery; and strategies to change organisational culture.

There were insufficient data to explore effects across important subgroups (e.g. whether effects of educational interventions varied by format, intensity or duration of birth preparation classes). The absence of evidence on the optimal education format is particularly concerning given that antenatal education is an established component of maternity care worldwide. Given that many women are in contact with the health system for care during pregnancy, interventions targeting women and families appear an appealing strategy with capacity to reach a large proportion of women, ensuring they are informed and that they receive the necessary support for informed decision-making. More research is needed to understand women-related determinants of birth choices so that the content and format of educational interventions can be tailored to relevant determinants of caesarean births.

Limited data were available on maternal and neonatal morbidity and mortality and healthcare resource utilisation. Reliable costeffectiveness data were available only for one intervention (implementation of clinical practice guidelines combined with audit and feedback) (Johri 2017). We did not find studies that assessed long-term maternal and infant outcomes. Future studies should address this knowledge gap.

Most of the included studies were conducted in high-income countries. The review findings are mostly generalisable to similar settings. However, differences in the determinants of caesarean births and healthcare systems may limit generalisability in some settings (e.g. the labourist model of obstetric care is largely limited to USA settings) (Rosenstein 2015; Srinivas 2016). None of the included studies were conducted in low-income countries.

\section{Certainty of the evidence}

The review included 29 studies evaluating a wide range of interventions. We judged the certainty of evidence to be high in only three comparisons (implementation of clinical practice guidelines combined with mandatory second opinion for caesarean section indication, implementation of clinical practice guidelines combined with audit and feedback, local opinion leader education). The certainty of evidence for the remaining interventions varied from very low (indicating considerable uncertainty in the effect estimates) to moderate (indicating that further research is likely to have an important impact in our confidence in the effect estimate and may change the estimate).

We downgraded the level of evidence for most outcomes, primarily because of study risk of bias (due to inadequate sequence generation and allocation concealment procedures) and imprecision of effect (due to small sample sizes and few numbers of events). Although we cannot entirely exclude the possibility of publication bias, we judged the likelihood of missing relevant studies as low given the comprehensive literature searches implemented.

\section{Potential biases in the review process}

The review has a number of limitations. We excluded many studies because of ineligible designs. It is possible that some of these studies contribute useful data that might complement evidence from the included studies. We were not able to reanalyse data from some studies because insufficient information was available. It is likely that we missed a number of relevant interventions because of lack of clear taxonomy in the classification of non-clinical interventions to reduce caesarean births. In addition, a number of relevant interventions were identified during the peer review process; we will consider these in the next update of the review. We judged that the two studies currently awaiting classification do not have any impact on the review conclusions

\section{Agreements and disagreements with other studies or reviews}

We identified six related reviews published in the last 10 years (Boatin 2018; Catling-Paull 2011a; Chaillet 2007; Long 2016; Lundgren 2015; Nilsson 2015).

The reviews addressed a range of strategies intended to reduce caesarean births or increase vaginal birth after caesarean. Similar to our review, most of the studies included in the reviews were from high-income countries and limited data were available on maternal and neonatal mortality and morbidity and costs. There were differences between the reviews and our review regarding search strategies (e.g. search periods covered), study eligibility criteria (e.g. our review excluded cohort studies), and criteria for assessing the certainty of evidence (e.g. our review applied GRADE system). These differences explain some of the differences in the conclusions reached by the reviews. Relevant findings of the reviews are summarised in Table 12.

\section{AUTHORS' CONCLUSIONS}

\section{Implications for practice}

We evaluated a wide range of non-clinical interventions intended to reduce unnecessary caesarean section births, targeting various stakeholders (women or families, healthcare professionals, healthcare organisations or facilities). Across all categories, we found eight interventions to have a beneficial effect on at least one primary outcome measure with low-, moderate- or high-certainty evidence, and no moderate- or high-certainty evidence of adverse effects: childbirth training workshop; nurseled applied relaxation training programme; psychosocial couple- 
based prevention programme; psychoeducation; implementation of clinical practice guidelines combined with mandatory second opinion for caesarean section indication; implementation of clinical practice guidelines combined with audit and feedback; physician education by local opinion leader (obstetriciangynaecologist); and collaborative midwifery-labourist model of care.

Decisions to implement the interventions in other settings need to take into account: the extent to which routine settings resemble those in the included studies (e.g. determinants of caesarean births), presence of specific groups who might benefit from the intervention (e.g. women having undergone previous caesarean section), organisation of healthcare system (e.g. staffing models of care), baseline rates of caesarean births, financial burden of the interventions, and availability of routine data (Lavis 2009).

\section{Implications for research}

We have identified knowledge gaps in primary research based on uncertainty in the available evidence (due to very low- or lowcertainty evidence, applicability of evidence or lack of studies, particularly around interventions targeted at women or families and healthcare organisations or facilities). We have also provided recommendations to improve aspects of study methodology and reporting. The research priorities are summarised in Table 13. We identified eight ongoing trials.

\section{ACKNOWLEDGEMENTS}

We would like to acknowledge the support of the National Institute for Health Research (NIHR), via Cochrane Infrastructure funding to the Effective Practice and Organisation of Care (EPOC) Group. The views and opinions expressed herein are those of the authors and do not necessarily reflect those of the NIHR.

We would like to thank the following individuals who provided prepublication comments for this update: EPOC and Cochrane Editors, Gillian Leng, Celeste Naude, Jemma Hudson, Toby Lasserson and Julia Worswick; and Paul Miller (EPOC Information Specialist). We would also like to thank Susan Bewley and the following members of the Cochrane Pregnancy and Childbirth International Consumer Panel: Gill Gyte, Alina Bishop, Rachel Plachcinski, Misty Pratt and Carol Sakala. 


\section{R E F E R E N C E S}

\section{References to studies included in this review}

Althabe 2004 \{published data only\}

Althabe F, Belizan JM, Villar J, Alexander S, Bergel E, Ramos S, et al. Mandatory second opinion to reduce rates of unnecessary caesarean sections in Latin America: a cluster randomised control trial. Lancet 2004;363(9425):1934-40.

\section{Ayres-De-Campos 2015 \{published data only\}}

Ayres-De-Campos D, Cruz J, Medeiros-Borges C, Costa-Santos C, Vicente L. Lowered national cesarean section rates after a concerted action. Acta Obstetricia et Gynecologica Scandinavica 2015;94(4):391-8.

\section{Bastani 2006 \{published data only\}}

Bastani F, Hidarnia A, Kazemnejad A, Vafaei M, Kashanian M. A randomized controlled trial of the effects of applied relaxation training on reducing anxiety and perceived stress in pregnant women. Journal of Midwifery \& Women's Health 2005;50(4):e36e40.

* Bastani F, Hidarnia A, Montgomery KS, Aguilar-Vafaei ME, Kazemnejad A. Does relaxation education in anxious primigravid Iranian women influence adverse pregnancy outcomes? A randomised controlled trial. Journal of Perinatal \& Neonatal Nursing 2006;20(2):138-46.

\section{Bergstrom 2009 \{published data only\}}

Bergstrom M, Kieler H, Waldenstrom U. Psychoprophylaxis during labor: associations with labor-related outcomes and experience of childbirth. Acta Obstetricia et Gynecologica Scandinavica 2010;89(6):794-800.

* Bergström M, Kieler H, Waldenström U. Effects of natural childbirth preparation versus standard antenatal education on epidural rates, experience of child birth and parental stress in mothers and fathers. British Journal of Obstetrics and Gynaecology 2009;116(9):1167-76.

\section{Chaillet 2015 \{published data only\}}

Chaillet N, Dumont A, Abrahamowicz M, Pasquier JC, Audibert F, Monnier P, et al. QUARISMA Trial Research Group. A clusterrandomized trial to reduce cesarean delivery rates in Quebec. New England Journal of Medicine 2015;372(18):1710-21.

\section{Eden 2014 \{published data only\}}

Eden KB, Perrin NA, Vesco KK, Guise JM. A randomized comparative trial of two decision tools for pregnant women with prior cesareans. Journal of Obstetric, Gynecologic, and Neonatal Nursing 2014;43(5):568-79.

\section{Feinberg 2015 \{published data only\}}

Feinberg ME, Roettger ME, Jones DE, Paul IM, Kan ML. Effects of a psychosocial couple-based prevention program on adverse birth outcomes. Maternal and Child Health Journal 2015;19(1):102-11.

\section{Fenwick 2015 \{published data only\}}

Fenwick J, Toohill J, Gamble J, Creedy DK, Buist A, Turkstra E, et al. Effects of a midwife psycho-education intervention to reduce childbirth fear on women's birth outcomes and postpartum psychological wellbeing. BMC Pregnancy Childbirth 2015;15:284.

\section{Fraser 1997 \{published data only\}}

Fraser W, Maunsell E, Hodnett E, Moutquin J-M. Randomized controlled trial of a prenatal vaginal birth after cesarean section education and support program. American Journal of Obstetrics and Gynecology 1997;176(2):419-25.

\section{Hemminki 2008 \{published data only\}}

Hemminki E, Heikkila K, Sevon T, Koponen P. Special features of health services and register based trials - experiences from a randomised trial of childbirth classes. BMC Health Services Research 2008;8:126-34.

\section{Keeler 1996 \{published data only\}}

Keeler EB, Fok T. Equalizing physician fees had little effect on cesarean rates. Medical Care Research and Review 1996;53(4):465-71.

\section{Liang 2004 \{published data only\}}

Liang WH, Yuan CC, Hung JH, Yang ML, Yang MJ, Chen YJ. Effect of peer review and trial of labor on lowering cesarean section rates. Journal of the Chinese Medical Association 2004;67(6):281-6.

\section{Lo 2008 \{published data only\}}

Lo JC. Financial incentives do not always work - an example of cesarean sections in Taiwan. Health Policy 2008;88(1):121-9.

\section{Lomas 1991 \{published data only\}}

Lomas J, Enkin M, Anderson GM, Hannah WJ, Vayda E, Singer J. Opinion leaders vs adult and feedback to implement practice guidelines. Delivery after previous cesarean section. JAMA 1991;265(17):2202-7.

\section{Masoumi 2016 \{published data only\}}

Masoumi SZ, Kazemi F, Oshvandi K, Jalali M, EsmaeiliVardanjani A, Rafiei $\mathrm{H}$. Effect of training preparation for childbirth on fear of normal vaginal delivery and choosing the type of delivery among pregnant women in Hamadan, Iran: A randomized controlled trial. Journal of Family and Reproductive Health 2016;10(3):115-21.

\section{Mohammadi 2012 \{published data only\}}

Mohammadi S, Kallestal C, Essen B. A practical strategy for reducing cesarean section rates in a general hospital in Tehran, Iran. Journal of Reproductive Medicine 2012;57(1-2):43-8.

\section{Montgomery 2007 \{published data only\} \\ * Montgomery AA, Emmett CL, Fahey T, Jones C, Ricketts I, Patel RR, Peters TJ, Murphy DJ, DiAMOND Study Group. Two decision aids for mode of delivery among women with previous caesarean section: randomised controlled trial. $B M J$ 2007;334(7607):1305-12.}

Montgomery AA, DiAMOND Study Group. The DiAMOND trial protocol: a randomised controlled trial of two decision aids 
for mode of delivery among women with a previous caesarean section. BMC Pregnancy and Childbirth 2004;4(1):25-32.

Navaee 2015 \{published data only\}

Navaee M, Abedian Z. Effect of role play education on primiparous women's fear of natural delivery and their decision on the mode of delivery. Iranian Journal of Nursing and Midwifery Research 2015;20(1):40-6.

Poma 1998 \{published data only\}

Poma PA. Effect of departmental policies on cesarean delivery rates: a community hospital experience. Obstetrics and Gynecology 1998;91(6):1013-8.

\section{Rosenstein 2015 \{published data only\}}

Rosenstein MG, Nijagal M, Nakagawa S, Gregorich SE, Kuppermann M. The association of expanded access to a collaborative midwifery and laborist model with cesarean delivery rates. Obstetrics and Gynecology 2015;126(4):716-23.

\section{Rouhe 2013 \{published data only\}}

Rouhe H, Salmela-Aro K, Toivanen R, Tokola M, Halmesmäki E, Saisto T. Obstetric outcome after intervention for severe fear of childbirth in nulliparous women - randomised trial. BJOG 2013;120(1):75-84.

\section{Runmei 2012 \{published data only\}}

Runmei M, Lao Terence T, Yonghu S, Hong X, Yuqin T, Bailuan L, et al. Practice audits to reduce caesareans in a tertiary referral hospital in south-western China. Bulletin of the World Health Organization 2012;90(7):488-94.

\section{Saisto 2001 \{published data only\}}

Saisto T, Salmela-Aro K, Nurmi JE, Könönen T, Halmesmäki E. A randomized controlled trial of intervention in fear of childbirth. Obstetrics and Gynecology 2001;98(5):820-6.

\section{Scarella 2011 \{published data only\}}

Scarella A, Chamy V, Sepulveda M, Belizan JM. Medical audit using the Ten Group Classification System and its impact on the cesarean section rate. European Journal of Obstetrics Gynecology and Reproductive Biology 2011;154(2):136-40.

\section{Sharifirad 2013 \{published data only\}}

Sharifirad G, Rezaeian M, Soltani R, Javaheri S, Mazaheri MA. A survey on the effects of husbands' education of pregnant women on knowledge, attitude, and reducing elective cesarean section. Journal of Education and Health Promotion 2013;2:50.

\section{Shorten 2005 \{published data only\}}

Shorten A, Shorten B, Keogh J, West S, Morris J. Making choices for childbirth: a randomised controlled trial of a decision-aid for informed birth after cesarean. Birth 2005;32(4):252-61.

\section{Srinivas 2016 \{published data only\}}

Srinivas SK, Small DS, Macheras M, Hsu JY, Caldwell D, Lorch S. Evaluating the impact of the laborist model of obstetric care on maternal and neonatal outcomes. American Journal of Obstetrics and Gynecology 2016;215(6):770.e1-.e9.
Valiani 2014 \{published data only\}

Valiani M, Haghighatdana Z, Ehsanpour S. Comparison of childbirth training workshop effects on knowledge, attitude, and delivery method between mothers and couples groups referring to Isfahan health centers in Iran. Iranian Journal of Nursing and Midwifery Research 2014;19(6):653-8.

Wang 2014 \{published data only\}

Wang X, Li GY, Deng, ML. Pelvic floor muscle training as a persistent nursing intervention: Effect on delivery outcome and pelvic floor myodynamia. International Journal of Nursing Sciences 2014;1:48-52.

\section{References to studies excluded from this review}

Afshar 2015 \{published data only\}

Afshar Y, Mei J, Wong M, Gregory K, Kilpatrick S, Esakoff T. The role of the birth plan in obstetrical and neonatal outcomes and birth experience satisfaction. American Journal of Obstetrics and Gynecology 2015;212(1):S282.

Arrieta 2011 \{published data only\}

Arrieta A. Health reform and cesarean sections in the private sector: The experience of Peru. Health Policy 2011;99(2):124-30.

Bailey 2010 \{published data only\}

Bailey PE, Binh HT, Bang HT. Promoting accountability in obstetric care: use of criteria-based audit in Viet Nam. Global Public Health 2010;5(1):62-74.

Barber 2010 \{published data only\}

Barber SL. Mexico's conditional cash transfer programme increases cesarean section rates among the rural poor. European Journal of Public Health 2010;20(4):383-8.

Bernitz 2011 \{published data only\}

Bernitz S, Rolland R, Blix E, Jacobsen M, Sjøborg K, Øian P. Is the operative delivery rate in low-risk women dependent on the level of birth care? A randomised controlled trial. BJOG 2011;118(11):1357-64.

Bonfrer 2016 \{published data only\}

Bonfrer I, Breebaart L, Van de Poel E. The effects of Ghana's National Health Insurance Scheme on maternal and infant health care utilization. PLoS One 2016;11(11):e0165623.

\section{Calvo 2009 \{published data only\}}

Calvo A, Campillo C, Juan M, Roig C, Hermoso JC, Cabeza PD. Effectiveness of a multifaceted strategy to improve the appropriateness of cesarean sections. Acta Obstetricia et Gynecologica 2009;88(7):842-5.

\section{Chambliss 1992 \{published data only\}}

Chambliss LR, Daly C, Medearis AL, Ames M, Kayne M, Paul R. The role of selection bias in comparing caesarean birth rates between physician and midwifery management. Obstetrics and Gynecology 1992;80:161-5. 


\section{Chen 2014 \{published data only\}}

Chen CS, Liu TC, Chen B, Lin CL. The failure of financial incentive? The seemingly inexorable rise of cesarean section. Social Science \& Medicine 2014;101:47-51.

\section{Chittithavorn 2006 \{published data only\}}

Chittithavorn S, Pinjaroen S, Suwanrath C, Soonthornpun K. Clinical practice guideline for cesarean section due to cephalopelvic disproportion. Journal of the Medical Association of Thailand 2006;89(6):735-40.

\section{Costa 2009 \{published data only\}}

Costa ML, Cecatti JG, Milanez HM, Souza JP, Gulmezoglu M. Audit and feedback: effects on professional obstetrical practice and healthcare outcomes in a university hospital. Acto Obstetricia et Gynecologica 2009;88(7):793-800.

\section{David 2001 \{published data only\}}

David S, Mamelle N, Riviere O. Estimation of an expected caesarean section rate taking into account the case mix of a maternity hospital. Analysis from the AUDIPOG Sentinelle Network (France). British Journal of Obstetrics and Gynaecology 2001;108(9):919-26.

\section{Dunn 2013 \{published data only\}}

Dunn S, Sprague AE, Fell DB, Dy S, Harrold S, Lamontagne B, et al. The use of a quality indicator to reduce elective repeat caesarean section for low-risk women before 39 Weeks' gestation: The Eastern Ontario experience. Journal of Obstetrics and Gynaecology Canada 2013;35(4):306-16.

\section{Fournier 2014 \{published data only\}}

Fournier P, Dumont A, Tourigny C, Philibert A, Coulibaly A, Traoré $M$. The free caesareans policy in low-income settings: an interrupted time series analysis in Mali (2003-2012). PLoS One 2014;9(8):e105130.

\section{Ganji 2006 \{published data only\}}

Ganji F, Yusefi H, Baradaran A. Effect of a participatory intervention to reduce the number of unnecessary caesarean sections performed in Shahrekord of Iran. Journal of Medical Sciences 2006;6(4):690-2.

\section{Gilbert 2012 \{published data only\}}

Gilbert W, Bliss MC, Johnson A, Gregg L, Swanson C. Effect of education and provider transparency upon individual cesarean, episiotomy, antenatal steroid, and breastfeeding rates. American Journal of Obstetrics and Gynecology 2012;26(1):A1A38, S1-S386.

\section{Gregory 1999 \{published data only\}}

Gregory KD, Hackmeyer P, Gold L, Johnson AI, Platt LD. Using the continuous quality improvement process to safely lower the cesarean section rate. Joint Commission Journal on Quality Improvement 1999;25(12):619-29.

\section{Gruber 1999 \{published data only\}}

Gruber J, Kim J, Mayzlin D. Physician fees and procedure intensity: the case of cesarean delivery. Journal of Health Economics 1999;18(4):473-90.

\section{Hemminki 2013 \{published data only\}}

Hemminki E, Long Q, Zhang WH, Wu Z, Raven J, Tao F, et al. Impact of financial and educational interventions on maternity care: results of cluster randomized trials in rural China, CHIMACA. Maternal and Child Health Journal 2013;17:208-21.

Ho 2011 \{published data only\}

Ho JJ, Japaraj RP, Che Anuar CY, van Rostenberghe HA, Paeds SA, Chang ASM, et al. Influence of a targeted educational intervention on evidence-based practice in two Malaysian maternity units: The sea ORCHID project in Malaysia. Medical Journal of Malaysia 2011;66(4):288-95.

Howell 2004 \{published data only\}

Howell EM, Dubay L, Kenney G, Sommers AS. The impact of Medicaid managed care on pregnant women in Ohio: a cohort analysis. Health Services Research 2004;39(4):825-46.

\section{Hutcheon 2015 \{published data only\}}

Hutcheon JA, Strumpf EC, Harper S, Giesbrecht E. Maternal and neonatal outcomes after implementation of a hospital policy to limit low-risk planned caesarean deliveries before 39 weeks of gestation: an interrupted time-series analysis. BJOG 2015;122(9):1200-6.

Iglesias 1991 \{published data only\} Iglesias S, Burn R, Saunders D. Reducing the cesarean section rate in a rural community hospital. Canadian Medical Association Journal 1991;146(10):1459-64.

\section{Jenabi 2012 \{published data only\}}

Jenabi E, Hajiloo MM, Torkamani M. The effect of reflexology on relieving the labor pain. Iranian Journal of Obstetrics, Gynecology and Infertility 2012;14(8):34-8.

\section{Jiang 2015 \{published data only\}}

Jiang Y, Liu XW. Effect of new-pattern obstetrical nursing in reducing cesarean delivery rate. Journal of Biological Regulators and Homeostatic Agents 2015;29(4):847-51.

\section{Kasawara 2013 \{published data only\}}

Kasawara KT, Burgos CS, Do Nascimento SL, Ferreira NO, Surita FG, Pinto E Silva JL. Maternal and perinatal outcomes of exercise in pregnant women with chronic hypertension and/ or previous preeclampsia: A randomized controlled trial. ISRN Obstetrics and Gynecology 2013;857047:1-8.

\section{Kazandjian 1998 \{published data only\}}

Kazandjian VA, Lied TR. Cesarean section rates: effects of participation in a performance measurement project. Joint Commission Journal on Quality Improvement 1998;24(4):187-96.

\section{Kim 2005 \{published data only\}}

Kim C-Y, Ko S-K, Kim K-Y. Are league tables controlling epidemic of caesarean sections in South Korea?. BJOG: an International Journal of Obstetrics and Gynaecology 2005;112(5):607-11.

Kiwankura 1993 \{published data only\}

Kiwankura Al, Moore WM. Influence of audit and feedback on the use of caesarean section in a geographically defined 
population. European Journal of Obstetrics, Gynecology and Reproductive Biology 1993;50(1):59-64.

\section{Kongnyuy 2008 \{published data only\}}

Kongnyuy EJ, Leigh B, van den Broek N. Effect of audit and feedback on the availability, utilisation and quality of emergency obstetric care in three districts in Malawi. Women and Birth 2008;21(4):149-55.

\section{Koroukian 2001 \{published data only\}}

Koroukian SM, Bush D, Rimm AA. Comparison of cesarean section rates in fee-for-service versus managed care patients in the Ohio Medicaid population, 1992-1997. American Journal of Managed Care 2001;7(2):134-42.

\section{Kunthonkitidej 2001 \{published data only\}}

Kunthonkitidej K, Ngernset O. Self-evaluation of obstetricians by delivery data to reduce cesarean section rate in Chai Nat Hospital. Journal of the Medical Association of Thailand 2001;84(11):1587-93.

\section{Lagrew 1996 \{published data only\}}

Lagrew DC Jr, Morgan MA. Decreasing the cesarean section rate in a private hospital: success without mandated clinical changes. American Journal of Obstetrics and Gynaecology 1996;174(1):184-91.

\section{Law 1999 \{published data only\}}

Law YY, Lam KY. A randomized controlled trial comparing midwife-managed care and obstetrician-managed care for women assessed to be at low risk in the initial intrapartum period. Journal of Obstetrics and Gynaecology Research 1999;25(2):107-12.

\section{Lee 2007 \{published data only\}}

Lee K, Lee S. Effects of the DRG-based prospective payment system operated by the voluntarily participating providers on the cesarean section rates in Korea. Health Policy 2007;81(2-3):300-8.

\section{Leone 2016 \{published data only\}}

Leone T, Cetorelli V, Neal S, Matthews Z. Financial accessibility and user fee reforms for maternal healthcare in five subSaharan countries: a quasi-experimental analysis. BMJ Open 2016;6(1):e009692.

\section{Main 1999 \{published data only\}}

Main EK. Reducing cesarean birth rates with data-driven quality improvement activities. Pediatrics 1999;103(1 Suppl E):374-83.

\section{Misra 2008 \{published data only\}}

Misra A. Impact of the HealthChoice Program on cesarean section and vaginal birth after $\mathrm{C}$-section deliveries: a retrospective analysis. Maternal Child Health Journal 2008;12(2):266-74

\section{Morhason-Bello 2009 \{published data only\}}

Morhason-Bello IO, Adedokun BO, Ojengbede OA, Olayemi O, Oladokun A, Fabamwo AO. Assessment of the effect of psychosocial support during childbirth in Ibadan, southwest Nigeria: a randomised controlled trial. Australian and New Zealand Journal of Obstetrics and Gynaecology 2009;49(2):145-50.

Myers 1993 \{published data only\}

Myers SA, Gleicher N. The Mount Sinai cesarean section reduction program: an update after 6 years. Social Science and Medicine 1993;37(10):1219-22.

Oleske 1992 \{published data only\}

Oleske DM, Glandon GL, Tancredi DJ, Nassirpour M, Noak JR. Information dissemination and the cesarean birth rate. The Illinois experience. International Journal of Technology Assessment in Health Care 1992;8(4):708-18.

Robson 1996 \{published data only\}

Robson MS, Scudamore IW, Walsh SM. Using the medical audit cycle to reduce cesarean section rates. American Journal of Obstetrics and Gynaecology 1996;174(1 Pt 1):199-205.

Saint 2003 \{published data only\}

Saint S, Hofer TP, Rose JS, Kaufman SR, McMahon LF Jr. Use of critical pathways to improve efficiency: a cautionary tale. American Journal of Managed Care 2003;9(11):758-65.

Sanavi 2014 \{published data only\}

Sanavi FS, Ansari-Moghaddam A, Shovey MF, Rakhshani F. Effective education to decrease elective caesarean section. Journal of the Pakistan Medical Association 2014;64(5):500-5.

Santerre 1996 \{published data only\}

Santerre RE. The effect of the ACOG guideline on vaginal births after cesarean. Medical Care Research and Review 1996;53(3):315-29.

Socol 1993 \{published data only\}

Socol ML, Garcia PM, Peaceman AM, Dooley SL. Reducing cesarean births at a primarily private university hospital. American Journal of Obstetrics and Gynecology 1993;168(6 Pt 1):1748-58.

Tussey 2015 \{published data only\}

Tussey CM, Botsios E, Gerkin RD, Kelly LA, Gamez J, Mensik J. Reducing length of labor and cesarean surgery rate using a peanut ball for women laboring with an epidural. Journal of Perinatal Education 2015;24(1):16-24.

van Dillen 2008 \{published data only\} van Dillen J, Lim F, van Rijssel E. Introducing caesarean section audit in a regional teaching hospital in The Netherlands. European Journal of Obstetrics, Gynecology and Reproductive Biology 2008;139(2):151-6.

Walker 2016 \{published data only\} Walker DM, Cohen SR, Fritz J, Olvera-García M, Zelek ST, Fahey JO, et al. Impact evaluation of PRONTO Mexico: a simulation-based program in obstetric and neonatal emergencies and team training. Simulation in Healthcare 2016;11(1):1-9. 
Werner 2013 \{published data only\}

Werner A, Uldbjerg N, Zachariae R, Nohr EA. Effect of selfhypnosis on duration of labor and maternal and neonatal outcomes: A randomized controlled trial. Acta Obstetricia et Gynecologica Scandinavica 2013;92(7):816-23.

\section{Zanetta 1999 \{published data only\}}

Zanetta G, Tampieri A, Currado I, Regalia A, Nespoli A, Midwife T, et al. Changes in cesarean delivery in an Italian university hospital, 1982-1996: a comparison with the national trend. Birth 1999;26(3):144-8.

\section{Zhang 2016 \{published data only\}}

Zhang T, Liu C. Comparison between continuing midwifery care and standard maternity care in vaginal birth after cesarean. Pakistan Journal of Medical Sciences 2016;32(3):711-4.

\section{References to studies awaiting assessment}

Jang 2011 \{published data only\} Jang WM, Eun SJ, Lee CE, Kim Y. Effect of repeated public releases on cesarean section rates. Journal of Preventive Medicine and Public Health 2011;44(1):2-8.

Vankan 2015 \{published data only\}

Vankan E, Schoorel E, Van Kuijk S, Aardenburg R, Delemarre F, Dirksen $C$, et al. Patient decision aid with individual risk estimation: An effective tool in choosing the mode of delivery after cesarean section. American Journal of Obstetrics and Gynecology 2015;212:S240-1.

\section{References to ongoing studies}

\section{ACTRN12611000878976 \{published data only\}}

ACTRN12611000878976. The effect of an antenatal decision aid booklet on rate of vaginal birth after caesarean (VBAC) in women with previous caesarean section [For pregnant women in the first half of their pregnancy with history of previous caesarean and eligible for vaginal birth after caesarean (VBAC), will using a decision aid increase their rate of VBAC compared to using a pamphlet?]. www.anzctr.org.au/Trial/Registration/ TrialReview.aspx?id=343340 (first received 17 August 2011).

\section{ACTRN12611001214921 \{published data only\}}

ACTRN12611001214921. A randomised controlled trial to determine whether continuity of care increases the rate of attempted vaginal birth after caesarean (VBAC) [A randomised controlled trial to determine whether midwifery continuity of care increases the rate of attempted vaginal birth for women with a previous caesarean section]. anzctr.org.au/Trial/ Registration/TrialReview.aspx?id=347744 (first received 24 November 2011).

\section{ACTRN12613000161729 \{published data only\}}

ACTRN12613000161729. Enhanced care and support in early labour (ecsel) [Enhanced care and support in early labour (ecsel): a randomised controlled trial to reduce caesarean sections for first-time mothers]. https://www.anzctr.org.au/ Trial/Registration/TrialReview.aspx?id=335208 (first received 07 February 2013).

\section{IRCT2013111010777N3 \{published data only\}}

IRCT2013111010777N3. A computer based decision aids for mode of delivery (natural delivery or cesarean section) [The impact of a computerized decision aids on the mode of delivery, compared with conventional care]. who.int/trialsearch/ Trial3.aspx?trialid=IRCT2013111010777N3 (first received 19 November 2013)

\section{ISRCTN10612254 \{published data only\}}

ISRCTN10612254. Improving the organisation of maternal health service delivery, and optimising childbirth, by increasing vaginal birth after caesarean section (VBAC) through enhanced women-centred care. isrctn.com/ISRCTN10612254 (first received 3 April 2013)

ISRCTN48510263 \{published data only\}

ISRCTN48510263. Appropriate decision for caesarean section in Burkina Faso. isrctn.com/ISRCTN48510263 (first received 12 February 2014).

\section{ISRCTN50041378 \{unpublished data only\}}

ISRCTN50041378. A feasibility study and pilot randomised trial of an intervention designed to reduce unnecessary caesarean section in Ireland. isrctn.com/ISRCTN50041378 (first received 12 February 2018).

\section{NCT02874443 \{published data only\}}

NCT02874443. The REDUCED Trial: REDucing the Utilization of CEsarean Sections for Dystocia (REDUCED). clinicaltrials.gov/ ct2/show/NCT02874443 (first received 22 August 2016).

\section{Additional references ACOG 2013}

The American College of Obstetricians and Gynecologists. Cesarean delivery on maternal request. Committee Opinion No. 559. Obstetrics and Gynecology 2013;121:904-7.

\section{ACOG SMFM 2014}

Caughey AB, Cahill AG, Guise J-M, Rouse DJ, American College of Obstetricians and Gynecologists, Society for MaternalFetal Medicine. Safe prevention of the primary cesarean delivery. American Journal of Obstetrics and Gynecology 2014;210(3):179-93.

\section{Bermúdez-Tamayo 2018}

Bermúdez-Tamayo C, Johri M, Chaillet N. Budget impact of a program for safely reducing caesarean sections in Canada. Midwifery 2018;60:20-6.

\section{Bernal 2017}

Bernal JL, Cummins S, Gasparrini A. Interrupted time series regression for the evaluation of public health interventions: a tutorial. International Journal of Epidemiology 2017;46(1):348-55.

\section{Betrán 2016a}

Betrán AP, Ye J, Moller AB, Zhang J, Gülmezoglu AM, Torloni MR. The increasing trend in caesarean section rates: Global, 
regional and national estimates: 1990-2014. PLoS One 2016;11(2):e0148343.

\section{Betrán 2016b}

Betrán AP, Torloni MR, Zhang J, Gülmezoglu AM, WHO Working Group on Caesarean Section. WHO Statement on caesarean section rates. BJOG 2016;123(5):667-70.

\section{Boatin 2018}

Boatin AA, Cullinane F, Torloni MR, Betrán AP. Audit and feedback using the Robson classification to reduce caesarean section rates: a systematic review. BJOG 2018;125(1):36-42.

\section{Bohren 2017}

Bohren MA, Hofmeyr GJ, Sakala C, Fukuzawa RK, Cuthbert A. Continuous support for women during childbirth. Cochrane Database of Systematic Reviews 2017, Issue 7. [DOI: 10.1002/14651858.CD003766.pub6]

\section{Brown 2013}

Brown HC, Paranjothy S, Dowswell T, Thomas J. Package of care for active management in labour for reducing caesarean section rates in low-risk women. Cochrane Database of Systematic Reviews 2013, Issue 9. [DOI: 10.1002/14651858.CD004907.pub3]

\section{Catling-Paull 2011a}

Catling-Paull C, Johnston R, Ryan C, Foureur MJ, Homer CS. Non-clinical interventions that increase the uptake and success of vaginal birth after caesarean section: a systematic review. Journal of Advanced Nursing 2011;67(8):1662-76.

\section{Catling-Paull 2011b}

Catling-Paull C, Johnston R, Ryan C, Foureur MJ, Homer CS. Clinical interventions that increase the uptake and success of vaginal birth after caesarean section: a systematic review. Journal of Advanced Nursing 2011;67(8):1646-61.

\section{Chaillet 2007}

Chaillet N, Dumont A. Evidence-based strategies for reducing cesarean section rates: a meta-analysis. Birth 2007;34(1):53-64.

\section{Cook 2013}

Cook JR, Jarvis S, Knight M, Dhanjal MK. Multiple repeat caesarean section in the UK: incidence and consequences to mother and child. A national, prospective, cohort study. BJOG 2013;120(1):85-91.

\section{Dweik 2014}

Dweik D, Girasek E, Mészáros G, Töreki A, Keresztúri A, Pál A. Non-medical determinants of cesarean section in a medically dominated maternity system. Acta Obstetricia et Gynecologica Scandinavica 2014;93(10):1025-33.

\section{EPOC 2015}

Cochrane Effective Practice, Organisation of Care (EPOC). EPOC Taxonomy, 2015. Available at epoc.cochrane.org/epoctaxonomy.

\section{EPOC 2017}

Cochrane Effective Practice, Organisation of Care (EPOC). EPOC resources for review authors, 2017. Available at epoc.cochrane.org/epoc-specific-resources-review-authors.

\section{Guyatt 2008}

Guyatt GH, Oxman AD, Kunz R, Vist GE, Falck-Ytter Y, Schünemann $\mathrm{HJ}$, et al. Rating quality of evidence and strength of recommendations: What is "quality of evidence" and why is it important to clinicians?. BMJ 2008;336(7651):995-8.

\section{Hartmann 2012}

Hartmann KE, Andrews JC, Jerome RN, Lewis RM, Likis FE, McKoy JN, et al. Strategies to reduce cesarean birth in low-risk women. Rockville (MD): Agency for Healthcare Research and Quality (US). AHRQ Comparative Effectiveness Review 2012; Vol. Report No.: 12(13)-EHC128-EF.

\section{Hodnett 2012}

Hodnett ED, Downe S, Walsh D. Alternative versus conventional institutional settings for birth. Cochrane Database of Systematic Reviews 2012, Issue 8. [DOI: 10.1002/14651858.CD000012.pub4]

\section{Hoffmann 2014}

Hoffmann TC, Glasziou PP, Boutron I, Milne R, Perera R, Moher D, et al. Better reporting of interventions: template for intervention description and replication (TIDieR) checklist and guide. BMJ 2014;348:g1687.

\section{Hoxha 2017}

Hoxha I, Syrogiannouli L, Luta X, Tal K, Goodman DC, da Costa BR, et al. Caesarean sections and for-profit status of hospitals: systematic review and meta-analysis. BMJ Open 2017;7(2):e013670.

\section{Hsu 2008}

Hsu KH, Liao PJ, Hwang CJ. Factors affecting Taiwanese women's choice of Cesarean section. Social Science and Medicine 2008;66(1):201-9.

\section{i-WIP 2017}

The International Weight Management in Pregnancy (i-WIP) Collaborative Group. Effect of diet and physical activity based interventionsin pregnancy on gestational weight gain and pregnancy outcomes: meta-analysis of individual participant data from randomised trials. BMJ 2017;358:j3119.

\section{Ji 2015}

Ji H, Jiang H, Yang L, Qian X, Tang S. Factors contributing to the rapid rise of caesarean section: a prospective study of primiparous Chinese women in Shanghai. BMJ Open 2015;5(11):e008994.

\section{Johri 2017}

Johri M, Ng ESW, Bermudez-Tamayo C, Hoch JS, Ducruet T, Chaillet N. A cluster-randomized trial to reduce caesarean delivery rates in Quebec: cost-effectiveness analysis. BMC Medicine 2017;15(1):96. 


\section{Kabir 2004}

Kabir AA, Steinmann WC, Myers L, Khan MM, Herrera EA, Yu S, et al. Unnecessary cesarean delivery in Louisiana: an analysis of birth certificate data. American Journal of Obstetrics and Gynecology 2004;190(1):10-9; discussion 3A.

\section{Keag 2018}

Keag OE, Norman JE, Stock SJ. Long-term risks and benefits associated with cesarean delivery for mother, baby, and subsequent pregnancies: Systematic review and meta-analysis. PLoS Medicine 2018;15(1):e1002494.

\section{Koroukian 1998}

Koroukian SM, Trisel B, Rimm AA. Estimating the proportion of unnecessary cesarean sections in Ohio using birth certificate data. Journal of Clinical Epidemiology 1998;51(12):1327-34.

\section{Lavis 2009}

Lavis JN, Oxman AD, Souza NM, Lewin S, Gruen RL, Fretheim A. SUPPORT Tools for evidence-informed health Policymaking (STP) 9: Assessing the applicability of the findings of a systematic review. Health Research Policy and Systems 2009;7 Suppl 1:S9.

\section{Lin 2004}

Lin HC, Xirasagar S. Institutional factors in cesarean delivery rates: policy and research implications. Obstetrics and Gynecology 2004;103(1):128-36.

\section{Lo 2003}

Lo JC. Patients' attitudes versus physician' determination: implications for cesarean sections. Social Science and Medicine 2003;57(1):91-6.

\section{Long 2016}

Long Q, Allanson ER, Pontre J, Tunçalp Ö, Hofmeyr GJ, Gülmezoglu AM. Onsite midwife-led birth units (OMBUs) for care around the time of childbirth: a systematic review. BMJ Global Health 2016;1(2):e000096.

\section{Lundgren 2015}

Lundgren I, Smith V, Nilsson C, Vehvilainen-Julkunen K, Nicoletti J, Devane D, et al. Clinician-centred interventions to increase vaginal birth after caesarean section (VBAC): a systematic review. BMC Pregnancy Childbirth 2015;15:16.

\section{Luthy 2003}

Luthy DA, Malmgren JA, Zingheim RW, Leininger CJ. Physician contribution to a cesarean delivery risk model. American Journal of Obstetrics and Gynecology 2003;188(6):1579-85.

\section{Marshall 2011}

Marshall NE, Fu R, Guise JM. Impact of multiple cesarean deliveries on maternal morbidity: a systematic review. American Journal of Obstetrics and Gynecology 2011;205(3):262.e1-8.

\section{Mi 2014}

Mi J, Liu F. Rate of caesarean section is alarming in China. Lancet 2014;383(9927):1463-4.

\section{NCC-WCH 2011}

National Collaborating Centre for Women's and Children's Health. Caesarean Section. London: RCOG Press, 2011.

\section{NICE 2013}

National Institute for Health and Clinical Excellence. Caesarean section: Evidence update March 2013. Evidence Update 2013; Vol. 35.

\section{Nilsson 2015}

Nilsson C, Lundgren I, Smith V, Vehvilainen-Julkunen K, Nicoletti J, Devane $D$, et al. Women-centred interventions to increase vaginal birth after caesarean section (VBAC): A systematic review. Midwifery 2015;31(7):657-63.

\section{O'Connor 1999}

O'Connor AM, Drake ER, Fiset V, Graham ID, Laupacis A, Tugwell P. The Ottawa patient decision aids. Effective Clinical Practice: ECP 1999;2(4):163-70.

\section{Olsen 2012}

Olsen O, Clausen JA. Planned hospital birth versus planned home birth. Cochrane Database of Systematic Reviews 2012, Issue 9. [DOI: 10.1002/14651858.CD000352.pub2]

\section{Pang 2008}

Pang MW, Leung TN, Lau TK, Hang Chung TK. Impact of first childbirth on changes in women's preferences for mode of delivery: follow-up of a longitudinal observational study. Birth 2008;35(2):121-8.

\section{Robson 2001}

Robson MS. Classification of caesarean sections. Fetal and Maternal Medicine Review 2001;12:23-39.

\section{Sandall 2016}

Sandall J, Soltani H, Gates S, Shennan A, Devane D. Midwife-led continuity models versus other models of care for childbearing women. Cochrane Database of Systematic Reviews 2016, Issue 4. [DOI: 10.1002/14651858.CD004667.pub5]

\section{Scioscia 2008}

Scioscia M, Vimercati A, Cito L, Chironna E, Scatterella D, Selvaggi LE. Social determinants of the increasing caesarean section rate in Italy. Minerva Ginecologica 2008;60(2):115-20. [PUBMED: 18487961]

\section{Thomas 2001}

Thomas J, Paranjothy S, Royal College of Obstetricians and Gynaecologists Clinical Effectiveness Support Unit. National Sentinel Caesarean Section Audit Report. www.rcog.org.uk/ globalassets/documents/guidelines/research--audit/nscs_ audit.pdf 2001.

\section{Timor-Tritsch 2012}

Timor-Tritsch IE, Monteagudo A. Unforeseen consequences of the increasing rate of cesarean deliveries: early placenta accreta and cesarean scar pregnancy. A review. American Journal of Obstetrics and Gynecology 2012;207(1):14-29. 


\section{WHO 1985}

World Health Organization. Appropriate technology for birth. Lancet 1985;2(8452):436-7.

\section{Ye 2015}

Ye J, Zhang J, Mikolajczyk R, Torloni MR, Gülmezoglu AM, Betrán AP. Association between rates of caesarean section and maternal and neonatal mortality in the 21st century: a worldwide population-based ecological study with longitudinal data. British Journal of Obstetrics and Gynaecology 2015;123(5):745-53.

\section{Zwecker 2011}

Zwecker P, Azoulay L, Abenhaim HA. Effect of fear of litigation on obstetric care: a nationwide analysis on obstetric practice. American Journal of Perinatology 2011;28(4):277-84.

\section{Öst 1988}

Öst LG. Applied relaxation: Description of an effective coping technique. Scandinavian Journal of Behaviour Therapy 1988;17(2):83-96.

\section{CHARACTERISTICS OF STUDIES}

Characteristics of included studies [ordered by study ID]

\section{References to other published versions of this review}

\section{Khunpradit 2005}

Khunpradit S, Lumbiganon P, Jaipukdee J, Laopaiboon M. Non-clinical interventions for reducing unnecessary caesarean section. Cochrane Database of Systematic Reviews 2005, Issue 4. [DOI: 10.1002/14651858.CD005528]

\section{Khunpradit 2011}

Khunpradit S, Tavender E, Lumbiganon P, Laopaiboon M, Wasiak J, Gruen RL. Non-clinical interventions for reducing unnecessary caesarean section. Cochrane Database of Systematic Reviews 2011, Issue 6. [DOI: 10.1002/14651858.CD005528.pub2]

* Indicates the major publication for the study

Althabe 2004

\begin{tabular}{ll}
\hline Methods & Cluster-randomised trial \\
\hline Participants & $\begin{array}{l}34 \text { hospitals* (Argentina, Brazil, Cuba, Guatemala and Mexico) with 149,276 women } \\
\text { Hospitals with similar baseline caesarean section rate of } 15 \% \text { or greater and more than } 1000 \text { deliveries } \\
\text { per year }\end{array}$ \\
\hline
\end{tabular}

Interventions Intervention: implementation of evidence-based guidelines with mandatory second opinion

Control: routine care as per local guidelines

Outcomes Caesarean section rate including elective and intrapartum, maternal length of hospital stay, maternal, perinatal and neonatal complications

\title{
Notes
}

\begin{abstract}
*36 hospitals were randomised but 2 hospitals were excluded due to one hospital closing after randomisation and therefore the matched hospital was also excluded.

Baseline (control group) CS rate: $24.6 \%$

Date of study: October 1998 to June 2000

Funding: European Union; Pan American Health Organization (PAHO/WHO); UNDP/UNFPA/WHO/World Bank Special Programme of Research; Development and Research Training in Human Reproduction of WHO; Research Support Fund of São Paulo State, Brazil; Maternal and Infant Programme, Buenos Aires, Argentina; Population Council-Regional Office for Latin America and the Caribbean; Epidemiological Research Center in Reproductive and Sexual Health, Guatemala; and Center of Studies in Maternal and Child Health of Campinas, Brazil

Conflicts of interest: the authors declare that they have no known conflict of interests.
\end{abstract}

\section{Risk of bias}


Althabe 2004 (Continued)

$\begin{array}{ll}\begin{array}{l}\text { Random sequence genera- } \\ \text { tion (selection bias) }\end{array} & \text { Low risk } \\ & \text { the statistical unit of the UNDP/UNFPA/WHO....with SAS statistical software" }\end{array}$

\begin{tabular}{lll}
$\begin{array}{l}\text { Allocation concealment } \\
\text { (selection bias) }\end{array}$ & Low risk & $\begin{array}{l}\text { "Paired units randomly assigned...randomisation was independently done in } \\
\text { the statistical unit of the UNDP/UNFPA/WHO...with SAS statistical software" }\end{array}$ \\
\hline $\begin{array}{l}\text { Blinding of participants } \\
\begin{array}{l}\text { and personnel (perfor- } \\
\text { mance bias) }\end{array}\end{array}$ & Low risk & Impact of possible performance bias on main outcomes considered minimal \\
All outcomes & &
\end{tabular}

\begin{tabular}{|c|c|c|}
\hline $\begin{array}{l}\text { Blinding of outcome as- } \\
\text { sessment (detection bias) } \\
\text { All outcomes }\end{array}$ & Low risk & Main outcomes (modes of delivery) objective \\
\hline $\begin{array}{l}\text { Baseline characteristics } \\
\text { similar? }\end{array}$ & Low risk & $\begin{array}{l}\text { "6-month period of baseline data collection...hospitals were matched by coun- } \\
\text { try, type of hospital and baseline caesarean section rate" }\end{array}$ \\
\hline $\begin{array}{l}\text { Baseline outcome mea- } \\
\text { surements similar? }\end{array}$ & Low risk & $\begin{array}{l}\text { "6-month period of baseline data collection...hospitals were matched by coun- } \\
\text { try, type of hospital and baseline caesarean section rate" }\end{array}$ \\
\hline $\begin{array}{l}\text { Incomplete outcome data } \\
\text { (attrition bias) } \\
\text { All outcomes }\end{array}$ & Low risk & No missing outcome data \\
\hline $\begin{array}{l}\text { Selective reporting (re- } \\
\text { porting bias) }\end{array}$ & Low risk & Data on all prespecified outcomes reported \\
\hline $\begin{array}{l}\text { Protected against contam- } \\
\text { ination? }\end{array}$ & Low risk & Group contamination considered unlikely (allocation by hospital) \\
\hline Other bias & Low risk & No evidence of other bias \\
\hline
\end{tabular}

Ayres-De-Campos 2015

\begin{tabular}{ll}
\hline Methods & Interrupted time series \\
\hline Participants & Portugal \\
& Births occurring in Portugal between 2000 and 2014 \\
\hline
\end{tabular}

Interventions
with the inclusion of CS rates as a criterion for hospital funding

\begin{tabular}{ll}
\hline Outcomes & CS rate, perinatal and maternal mortality, instrumental vaginal delivery, VBAC, hypoxia-related compli- \\
cations and perineal lacerations
\end{tabular}

Notes Governmental sources were used to obtain data on national CS, perinatal and maternal mortality rates

Baseline (control group) CS rate: $30.6 \%$

Date of study: 2000 and 2014

Funding: the authors stated that "No funding was received for the conduction of this study. The initial stages of the described concerted action were funded by the North Healthcare Regional Administration." 
Ayres-De-Campos 2015 (Continued)

Conflicts of interest: the authors declare that they have no known conflict of interests.

\section{Risk of bias}

\begin{tabular}{|c|c|c|}
\hline Bias & Authors' judgement & Support for judgement \\
\hline $\begin{array}{l}\text { Intervention independent } \\
\text { of other changes? }\end{array}$ & High risk & $\begin{array}{l}\text { "Concern over rising CS rates has increased in Portugal over the last years and } \\
\text { it is impossible to evaluate how much of the observed change was in effect } \\
\text { due to the concerted action" }\end{array}$ \\
\hline $\begin{array}{l}\text { Shape of the intervention } \\
\text { effect pre-specified? }\end{array}$ & High risk & Not stated \\
\hline $\begin{array}{l}\text { Intervention unlikely to af- } \\
\text { fect data collection? }\end{array}$ & Low risk & $\begin{array}{l}\text { "Data for national indicators were retrieved from official sources, whereas } \\
\text { those of state-owned hospitals were obtained from a database used for bench- } \\
\text { marking and hospital funding, so it is likely that individual hospitals put an ef- } \\
\text { fort into the quality of their data" }\end{array}$ \\
\hline $\begin{array}{l}\text { Incomplete outcome data } \\
\text { (attrition bias) } \\
\text { All outcomes }\end{array}$ & Unclear risk & Not stated \\
\hline $\begin{array}{l}\text { Selective reporting (re- } \\
\text { porting bias) }\end{array}$ & Low risk & All relevant prespecified outcomes reported \\
\hline $\begin{array}{l}\text { Knowledge of the allo- } \\
\text { cated interventions ade- } \\
\text { quately prevented during } \\
\text { the study? }\end{array}$ & Low risk & Main outcome of interest (mode of delivery) objective \\
\hline Other bias & Low risk & No evidence of other bias \\
\hline
\end{tabular}

\section{Bastani 2006}

\begin{tabular}{ll}
\hline Methods & Randomised trial \\
\hline Participants & Iran \\
& $\begin{array}{l}110 \text { primigravida women with high levels of anxiety (initial state/trait anxiety scores over 30) recruited } \\
\text { from } 3 \text { prenatal clinics in Iran } \\
\text { Inclusion criteria: primigravida women with a wanted pregnancy, aged 18 to 30, between } 14 \text { and } 28 \\
\text { weeks' gestation, high levels of anxiety, uncomplicated singleton pregnancies and no identified med- } \\
\text { ical or obstetrical risk factors } \\
\text { Exclusion criteria: any medical or obstetric complication during the } 7 \text { weeks of intervention and elec- } \\
\text { tive caesarean section }\end{array}$ \\
\hline Interventions & $\begin{array}{l}\text { Nurse-led 7-week applied relaxation training in groups } \\
\text { Control: routine hospital-based prenatal care }\end{array}$ \\
\hline Outcomes & $\begin{array}{l}\text { Non-vaginal deliveries (surgical or caesarean section and instrumental deliveries including forceps and } \\
\text { vacuum extraction), preterm birth, low birth weight }\end{array}$ \\
\hline Notes & Baseline (control group) CS rate: $40 \%$ \\
Date of study: October 2002 to February 2003 \\
Funding: Not reported
\end{tabular}


Bastani 2006 (Continued)

Conflicts of interest: Not reported

\section{Risk of bias}

\begin{tabular}{|c|c|c|}
\hline Bias & Authors' judgement & Support for judgement \\
\hline $\begin{array}{l}\text { Random sequence genera- } \\
\text { tion (selection bias) }\end{array}$ & Unclear risk & $\begin{array}{l}\text { "Randomly assigned to } 2 \text { groups, using a block randomisation method". Un- } \\
\text { clear on the size of the blocks }\end{array}$ \\
\hline $\begin{array}{l}\text { Allocation concealment } \\
\text { (selection bias) }\end{array}$ & Unclear risk & $\begin{array}{l}\text { "Randomly assigned to } 2 \text { groups, using a block randomisation method". Un- } \\
\text { clear on the size of the blocks }\end{array}$ \\
\hline $\begin{array}{l}\text { Blinding of participants } \\
\text { and personnel (perfor- } \\
\text { mance bias) } \\
\text { All outcomes }\end{array}$ & Unclear risk & No information provided in the report \\
\hline $\begin{array}{l}\text { Blinding of outcome as- } \\
\text { sessment (detection bias) } \\
\text { All outcomes }\end{array}$ & Low risk & Main outcomes (modes of delivery) objective \\
\hline $\begin{array}{l}\text { Baseline characteristics } \\
\text { similar? }\end{array}$ & Low risk & "No differences in the demographic variables...or the dependent variables" \\
\hline $\begin{array}{l}\text { Baseline outcome mea- } \\
\text { surements similar? }\end{array}$ & Low risk & $\begin{array}{l}\text { "No significant differences in state/anxiety....and perceived stress between the } \\
\text { groups before intervention" }\end{array}$ \\
\hline $\begin{array}{l}\text { Incomplete outcome data } \\
\text { (attrition bias) } \\
\text { All outcomes }\end{array}$ & Low risk & No missing outcome data \\
\hline $\begin{array}{l}\text { Selective reporting (re- } \\
\text { porting bias) }\end{array}$ & Low risk & Prespecified outcomes reported \\
\hline $\begin{array}{l}\text { Protected against contam- } \\
\text { ination? }\end{array}$ & Unclear risk & Insufficient information available to assess likelihood of contamination \\
\hline Other bias & Low risk & No evidence of other bias \\
\hline
\end{tabular}

\section{Bergstrom 2009}

\begin{tabular}{ll}
\hline Methods & Randomised trial \\
\hline Participants & Sweden \\
& $\begin{array}{l}\text { Inclusion criteria: Nulliparous, Swedish-speaking and attending any of the participating clinics. No spe- } \\
\text { cific inclusion criteria were defined for the women's partners }\end{array}$ \\
\hline Interventions & $\begin{array}{l}\text { Intervention: antenatal education focusing on natural childbirth preparation with training in breathing } \\
\text { and relaxation techniques (psychoprophylaxis) }\end{array}$ \\
& $\begin{array}{l}\text { Control: standard antenatal education focusing on both childbirth and parenthood, without psy- } \\
\text { choprophylactic training } \\
\text { Both groups: four 2-hour sessions in groups of } 12 \text { participants during third trimester of pregnancy and } \\
\text { one follow-up after delivery }\end{array}$
\end{tabular}


Bergstrom 2009 (Continued)

Outcomes
Mode of delivery, epidural analgesia, experience of childbirth, and parental stress in early parenthood

Baseline (Control group) CS rate: $21 \%$

Date of study: October 2005 to February 2007

Funding: Swedish Research Council and Karolinska Institute

Conflicts of interest: the authors declare that they have no known conflict of interests.

\section{Risk of bias}

\begin{tabular}{|c|c|c|}
\hline Bias & Authors' judgement & Support for judgement \\
\hline $\begin{array}{l}\text { Random sequence genera- } \\
\text { tion (selection bias) }\end{array}$ & Low risk & $\begin{array}{l}\text { "The randomisation was conducted by the computerised algorithm with two } \\
\text { priorities: Stratification by (1) equal number of participants per model in all } \\
\text { clinics taken together and (2) balancing the numbers of each model within the } \\
\text { respective clinic." }\end{array}$ \\
\hline $\begin{array}{l}\text { Allocation concealment } \\
\text { (selection bias) }\end{array}$ & Unclear risk & Insufficient information provided in the report \\
\hline $\begin{array}{l}\text { Blinding of participants } \\
\text { and personnel (perfor- } \\
\text { mance bias) } \\
\text { All outcomes }\end{array}$ & Unclear risk & Insufficient information provided in the report \\
\hline
\end{tabular}

\begin{tabular}{lll}
$\begin{array}{l}\text { Blinding of outcome as- } \\
\text { sessment (detection bias) } \\
\text { All outcomes }\end{array}$ & Unclear risk & Main outcomes (modes of delivery) objective \\
\hline $\begin{array}{l}\text { Baseline characteristics } \\
\text { similar? }\end{array}$ & Low risk & Baseline characteristics in study groups similar (Table 1 in the article) \\
\hline
\end{tabular}

Baseline outcome mea- Unclear risk Baseline measures of main outcomes not reported

surements similar?

\begin{tabular}{lll}
\hline $\begin{array}{l}\text { Incomplete outcome data } \\
\text { (attrition bias) } \\
\text { All outcomes }\end{array}$ & Low risk & $\begin{array}{l}\text { Numbers lost to follow-up (Figure } 1 \text { in the article) unlikely to bias effect esti- } \\
\text { mates }\end{array}$ \\
\hline $\begin{array}{l}\text { Selective reporting (re- } \\
\text { porting bias) }\end{array}$ & Low risk & Prespecified outcomes reported \\
\hline $\begin{array}{l}\text { Protected against contam- } \\
\text { ination? }\end{array}$ & High risk & Some women in standard care also got psychoprophylaxis education at home \\
\hline $\begin{array}{l}\text { Other bias } \\
\text { High risk }\end{array}$ & $\begin{array}{l}\text { Unit of analysis issues: "We have analysed data of individuals in spite of the } \\
\text { fact that exposures was given to groups of individuals." }\end{array}$ \\
\hline
\end{tabular}

\section{Chaillet 2015}

\begin{tabular}{ll}
\hline Methods & Cluster-randomised trial \\
\hline Participants & Canada
\end{tabular}


Participants: 32 public hospitals with at least 300 deliveries in the year before initiation of study and a CS rate $>17 \%$ and at the time of recruitment, no recent or ongoing quality improvement programmes designed to reduce CS rate.

All women who delivered at participating centres and whose newborns had a gestational age of at least 24 weeks and weighed at least $500 \mathrm{~g}$ at delivery

$\begin{array}{ll}\text { Interventions } & \text { Implementation of evidence-based guidelines (onsite training in evidence-based clinical practice, facil- } \\ \text { itation by local opinion leader, supervision), audits of indications for caesarean delivery and provision } \\ \text { of feedback to health professionals }\end{array}$

Outcomes $\begin{aligned} & \text { Caesarian section rate, vaginal delivery, pharmacologic induction of labour, artificial rupture of mem- } \\ & \text { branes, augmentation with oxytocin during labour, epidural analgesia, and episiotomy; }\end{aligned}$
$\begin{aligned} & \text { composite risks of minor and major maternal complications; and composite risks of minor and major } \\ & \text { neonatal complications, excluding lethal congenital abnormalities }\end{aligned}$

Notes

Baseline (control group) CS rate: $23.2 \%$

Date of study: April 2008 to October 2011

Funding: Canadian Institutes of Health Research

Conflicts of interest: the authors declare that they have no known conflict of interests.

\section{Risk of bias}

\begin{tabular}{lll}
\hline Bias & Authors' judgement & Support for judgement \\
\hline $\begin{array}{ll}\text { Random sequence genera- } \\
\text { tion (selection bias) }\end{array}$ & Low risk & $\begin{array}{l}\text { "To avoid imbalance in the size of the two groups, we used computer-generat- } \\
\text { ed, blocked randomization within each stratum, with blocks consisting of four } \\
\text { centers or, for strata with fewer than eight hospitals, two centers". Further de- } \\
\text { tails in trial protocol }\end{array}$ \\
& & \\
\hline
\end{tabular}

\begin{tabular}{|c|c|c|}
\hline $\begin{array}{l}\text { Allocation concealment } \\
\text { (selection bias) }\end{array}$ & Low risk & $\begin{array}{l}\text { "To avoid imbalance in the size of the two groups, we used computer-generat- } \\
\text { ed, blocked randomization within each stratum, with blocks consisting of four } \\
\text { centers or, for strata with fewer than eight hospitals, two centers. Local inves- } \\
\text { tigators at each hospital were then immediately informed of the assignment } \\
\text { status of their hospital." Further details in trial protocol }\end{array}$ \\
\hline
\end{tabular}

Blinding of participants Low risk Impact of possible performance bias on main outcomes considered minimal
and personnel (performance bias)

All outcomes

\begin{tabular}{lll}
\hline $\begin{array}{l}\text { Blinding of outcome as- } \\
\text { sessment (detection bias) } \\
\text { All outcomes }\end{array}$ & Low risk & Main outcomes of interest (mode of delivery) objective \\
\hline $\begin{array}{l}\text { Baseline characteristics } \\
\text { similar? }\end{array}$ & Low risk & Table 1 in the article: baseline characteristics comparable \\
\hline $\begin{array}{l}\text { Baseline outcome mea- } \\
\text { surements similar? }\end{array}$ & Low risk & Table 2 in the article: baseline outcome measures comparable \\
\hline $\begin{array}{l}\text { Incomplete outcome data } \\
\text { (attrition bias) } \\
\text { All outcomes }\end{array}$ & Low risk & No evidence of attrition bias \\
\hline
\end{tabular}


Chaillet 2015 (Continued)

Selective reporting (re- Low risk Data on all prespecified outcomes reported
porting bias)

\begin{tabular}{lll}
\hline $\begin{array}{l}\text { Protected against contam- } \\
\text { ination? }\end{array}$ & Low risk & $\begin{array}{l}\text { "By designating hospitals as the units of randomization, we ensured that all } \\
\text { women within a given maternity unit were assigned to the same trial group, } \\
\text { thereby reducing the risk of contamination of the intervention effect." }\end{array}$ \\
\hline Other bias & Low risk & No evidence of other bias \\
\hline
\end{tabular}

Eden 2014

\begin{tabular}{ll}
\hline Methods & Randomised trial \\
\hline Participants & USA \\
& $\begin{array}{l}\text { Pregnant women who had one prior caesarean and were eligible for VBAC participated one time be- } \\
\text { tween } 2005 \text { and } 2007\end{array}$ \\
\hline Interventions & Intervention: evidence-based, computerised decision aid \\
& Control: two evidence-based educational brochures about caesarean delivery and VBAC \\
\hline Outcomes & Change in decisional conflict around birth priorities, mode of delivery, birth priorities for women \\
\hline Notes & Baseline (control group) CS rate: not reported \\
& Date of study: 2005 to 2007 \\
& $\begin{array}{l}\text { Funding: OHSU Foundation; NIH K12 grant (Building Interdisciplinary Research Careers in Women's } \\
\text { Health, 5K12HD043488-04); grants } 1 \text { R03 HSO13959 from the Agency for Healthcare Research and Quali- } \\
\text { ty and } 1 \text { K08 HS11338-01 from the National Institute of Child Health \& Human Development } \\
\text { Conflict of interest: the authors declare that they have no known conflict of interests. }\end{array}$
\end{tabular}

\section{Risk of bias}

Bias Authors' judgement Support for judgement

$\begin{array}{ll}\begin{array}{l}\text { Random sequence genera- } \\ \text { tion (selection bias) }\end{array} & \text { Low risk } \\ & \text { obtain the decision tool assignment" }\end{array}$

\begin{tabular}{|c|c|c|}
\hline $\begin{array}{l}\text { Allocation concealment } \\
\text { (selection bias) }\end{array}$ & Low risk & $\begin{array}{l}\text { "The research assistant logged into the secured, randomization database to } \\
\text { obtain the decision tool assignment" }\end{array}$ \\
\hline $\begin{array}{l}\text { Blinding of participants } \\
\text { and personnel (perfor- } \\
\text { mance bias) } \\
\text { All outcomes }\end{array}$ & Low risk & "The women were unaware of their intervention assignment." \\
\hline $\begin{array}{l}\text { Blinding of outcome as- } \\
\text { sessment (detection bias) } \\
\text { All outcomes }\end{array}$ & Low risk & Outcome of interest (mode of delivery) objective \\
\hline $\begin{array}{l}\text { Baseline characteristics } \\
\text { similar? }\end{array}$ & Low risk & $\begin{array}{l}\text { "The two groups of women (those who received the brochures and those who } \\
\text { used the decision aid) were similar in all demographic, health insurance sta- } \\
\text { tus, birth intention and obstetric history variables." }\end{array}$ \\
\hline
\end{tabular}


Eden 2014 (Continued)

Baseline outcome mea- Unclear risk Insufficient information provided in the report surements similar?

\begin{tabular}{|c|c|c|}
\hline $\begin{array}{l}\text { Incomplete outcome data } \\
\text { (attrition bias) } \\
\text { All outcomes }\end{array}$ & Low risk & $\begin{array}{l}\text { "In cases of missing data for decisional conflict questions, a conservative ap- } \\
\text { proach was taken by assigning the missing response as unsure that was scored } \\
\text { as a 2." }\end{array}$ \\
\hline
\end{tabular}

\begin{tabular}{lll}
\hline $\begin{array}{l}\text { Selective reporting (re- } \\
\text { porting bias) }\end{array}$ & Low risk & $\begin{array}{l}\text { All relevant outcomes in the methods section are reported in the results sec- } \\
\text { tion }\end{array}$ \\
\hline $\begin{array}{l}\text { Protected against contam- } \\
\text { ination? }\end{array}$ & Unclear risk & Insufficient information available to assess likelihood of contamination \\
\hline Other bias & Low risk & No evidence of other bias \\
\hline
\end{tabular}

\section{Feinberg 2015}

\begin{tabular}{ll}
\hline Methods & Randomised trial \\
\hline Participants & USA \\
& $\begin{array}{l}\text { Pregnant women and their partner (couples were aged } 18 \text { and above, living together, and expecting a } \\
\text { first child at recruitment) } \\
\text { The analytic sample consisted of } 147 \text { mothers (71 from control, and } 76 \text { from the intervention group) } \\
\text { who completed interviews when children were } 6 \text { months old (wave 2), interviewed from } 2004 \text { to } 2006\end{array}$ \\
\hline Interventions & $\begin{array}{l}\text { Intervention: psychosocial couple-based prevention programme } \\
\text { Control: routine care (no educational classes) }\end{array}$ \\
\hline Delivery mode, complications of pregnancy and delivery, mother and newborn length of hospital stay \\
\hline Notes & $\begin{array}{l}\text { Baseline (control group) CS rate: } 40 \% \\
\text { Date of study: "The analytic sample consisted of } 147 \text { mothers (71 from control, and } 76 \text { from the inter- } \\
\text { vention group) who completed interviews when children were } 6 \text { months old (wave } 2 \text { ), interviewed from } \\
\text { 2004 to } 2006 . "\end{array}$ \\
$\begin{array}{l}\text { Funding: National Institute of Child Health and Development (K23 HD042575) and the National Institute } \\
\text { of Mental Health (R21 MH064125-01). } \\
\text { Conflict of interest: not reported }\end{array}$
\end{tabular}

\section{Risk of bias}

\begin{tabular}{lll}
\hline Bias & Authors' judgement & Support for judgement \\
\hline $\begin{array}{l}\text { Random sequence genera- } \\
\text { tion (selection bias) }\end{array}$ & Unclear risk & Insufficient information provided \\
\hline $\begin{array}{l}\text { Allocation concealment } \\
\text { (selection bias) }\end{array}$ & Unclear risk & Insufficient information provided \\
\hline $\begin{array}{l}\text { Blinding of participants } \\
\text { and personnel (perfor- } \\
\text { mance bias) }\end{array}$ & Unclear risk & Insufficient information provided \\
\hline
\end{tabular}


Feinberg 2015 (Continued)

All outcomes

Blinding of outcome as-
sessment (detection bias) $\quad$ Unclear risk Insufficient information provided

All outcomes

\begin{tabular}{|c|c|c|}
\hline $\begin{array}{l}\text { Baseline characteristics } \\
\text { similar? }\end{array}$ & Low risk & $\begin{array}{l}\text { In page } 4 \text { in the article: "To assess randomization, we performed attrition } \\
\text { analysis and baseline equivalence testing by intervention condition. Results } \\
\text { showed baseline equivalence across a wide array of pretest" }\end{array}$ \\
\hline
\end{tabular}

\begin{tabular}{lll}
\hline $\begin{array}{l}\text { Baseline outcome mea- } \\
\text { surements similar? }\end{array}$ & Unclear risk & Insufficient information provided \\
\hline $\begin{array}{l}\text { Incomplete outcome data } \\
\text { (attrition bias) } \\
\text { All outcomes }\end{array}$ & Unclear risk & Insufficient information provided \\
\hline $\begin{array}{l}\text { Selective reporting (re- } \\
\text { porting bias) }\end{array}$ & Low risk & $\begin{array}{l}\text { All relevant outcomes in the methods section are reported in the results sec- } \\
\text { tion }\end{array}$ \\
\hline $\begin{array}{l}\text { Protected against contam- } \\
\text { ination? }\end{array}$ & Unclear risk & Insufficient information available to assess likelihood of contamination \\
\hline \begin{tabular}{l} 
Other bias \\
\hline
\end{tabular} & Low risk & No evidence of other bias \\
\hline
\end{tabular}

Fenwick 2015

\begin{tabular}{|c|c|}
\hline Methods & Randomised trial \\
\hline \multirow[t]{3}{*}{ Participants } & Australia \\
\hline & $\begin{array}{l}\text { Inclusion criteria: women between } 12 \text { to } 24 \text { weeks gestation, aged } 16 \text { years and older, able to read, } \\
\text { write and understand English and with capacity to consent were invited to participate. (They should } \\
\text { have had higher fear levels (WDEQ-A } \geq 66 \text { )) }\end{array}$ \\
\hline & $\begin{array}{l}\text { Exclusion criteria: women who required an interpreter, or had a foetal diagnosis of major abnormality } \\
\text { or incompatibility with life were excluded }\end{array}$ \\
\hline \multirow[t]{2}{*}{ Interventions } & Intervention: psychoeducation by telephone \\
\hline & Control: routine maternity care \\
\hline \multirow[t]{3}{*}{ Outcomes } & $\begin{array}{l}\text { Caesarean section, induction of labour (amniotomy, prostaglandin or syntocinon), epidural use in } \\
\text { labour and neonatal admission to special care or intensive care nursery; }\end{array}$ \\
\hline & $\begin{array}{l}\text { Psychosocial outcomes: depressive symptoms, distressing flashbacks of the birth and parenting confi- } \\
\text { dence }\end{array}$ \\
\hline & Women's satisfaction with their ultimate birth mode and feelings of fear \\
\hline \multirow[t]{4}{*}{ Notes } & Baseline (control group) CS rate: $41.9 \%$ \\
\hline & Date of study: May 2012 to June 2013 \\
\hline & Funding: National Health \& Medical Research Council, NHMRC grant number APP1025099 \\
\hline & Conflict of interest: the authors declare that they have no known conflict of interests. \\
\hline
\end{tabular}

\section{Risk of bias}


Fenwick 2015 (Continued)

\begin{tabular}{|c|c|c|}
\hline Bias & Authors' judgement & Support for judgement \\
\hline $\begin{array}{l}\text { Random sequence genera- } \\
\text { tion (selection bias) }\end{array}$ & Low risk & $\begin{array}{l}\text { "Participants were allocated in blocks of ten and stratified by hospital site and } \\
\text { parity using a centralised web-based service to either intervention or control } \\
\text { group" }\end{array}$ \\
\hline $\begin{array}{l}\text { Allocation concealment } \\
\text { (selection bias) }\end{array}$ & Low risk & $\begin{array}{l}\text { "A research assistant not involved in recruitment or provision of the interven- } \\
\text { tion accessed the randomisation service following receipt of participant's writ- } \\
\text { ten consent and completed baseline measures." }\end{array}$ \\
\hline $\begin{array}{l}\text { Blinding of participants } \\
\text { and personnel (perfor- } \\
\text { mance bias) } \\
\text { All outcomes }\end{array}$ & Low risk & $\begin{array}{l}\text { Likelihood of performance bias considered low given the nature of interven- } \\
\text { tion (psychoeducation by telephone) }\end{array}$ \\
\hline $\begin{array}{l}\text { Blinding of outcome as- } \\
\text { sessment (detection bias) } \\
\text { All outcomes }\end{array}$ & Low risk & Main outcome of interest (delivery mode) objective \\
\hline $\begin{array}{l}\text { Baseline characteristics } \\
\text { similar? }\end{array}$ & Low risk & Participant characteristics comparable \\
\hline $\begin{array}{l}\text { Baseline outcome mea- } \\
\text { surements similar? }\end{array}$ & Unclear risk & Insufficient information provided in the report \\
\hline $\begin{array}{l}\text { Incomplete outcome data } \\
\text { (attrition bias) } \\
\text { All outcomes }\end{array}$ & Low risk & $\begin{array}{l}\text { "There was no difference in the proportion of women in the intervention group } \\
\text { and the control groups that dropped out of the study ( } 46.5 \% \text { and } 45 \% \text { respec- } \\
\text { tively, } \mathrm{P}=0.78) . "\end{array}$ \\
\hline $\begin{array}{l}\text { Selective reporting (re- } \\
\text { porting bias) }\end{array}$ & Low risk & Data on all prespecified outcomes reported \\
\hline $\begin{array}{l}\text { Protected against contam- } \\
\text { ination? }\end{array}$ & Low risk & $\begin{array}{l}\text { Likelihood of contamination considered low given the nature of intervention } \\
\text { (psychoeducation by telephone) }\end{array}$ \\
\hline Other bias & Low risk & No evidence of other bias \\
\hline
\end{tabular}

\section{Fraser 1997}

\begin{tabular}{ll}
\hline Methods & Randomised trial \\
\hline Participants & 12 hospitals: 11 Canada and 1 USA \\
& Pregnant women with single previous low caesarean birth with gestational age $<28$ weeks \\
& Exclusion: women with previous VBAC, classic caesarean scar or known multiple pregnancies
\end{tabular}

\begin{tabular}{ll}
\hline Interventions & $\begin{array}{l}\text { Prenatal education and support programme (first contact for provision of education and support at } \\
\text { randomisation, second contact } 8 \text { weeks later) }\end{array}$
\end{tabular}

Outcomes

Attempt vaginal delivery, VBAC, caesarean section scheduled, unsuccessful or urgent, maternal morbidity, neonatal mortality and morbidity

Notes

Baseline (control group) CS rate: $26.3 \%$

Date of study: April 1992 to November 1994 
Funding: supported by operating grant No. MT 11430 from the Medical Research Council of Canada and by nominal awards (W.F. from the Medical Research Council of Canada, grant No DG-401; E.M.

from the National Health Research and Development Program, National Health Research Scholar, No. 6605-2487-47).

Conflict of interest: not reported

\section{Risk of bias}

\begin{tabular}{|c|c|c|}
\hline Bias & Authors' judgement & Support for judgement \\
\hline $\begin{array}{l}\text { Random sequence genera- } \\
\text { tion (selection bias) }\end{array}$ & Low risk & $\begin{array}{l}\text { Likely: "Randomization, which was performed through a centralized telephone } \\
\text { answering service, was blocked and stratified by hospital and by the woman's } \\
\text { motivation to attempt vaginal delivery." }\end{array}$ \\
\hline $\begin{array}{l}\text { Allocation concealment } \\
\text { (selection bias) }\end{array}$ & Low risk & $\begin{array}{l}\text { "Randomization, which was performed through a centralized telephone an- } \\
\text { swering service, was blocked and stratified by hospital and by the woman's } \\
\text { motivation to attempt vaginal delivery." }\end{array}$ \\
\hline $\begin{array}{l}\text { Blinding of participants } \\
\text { and personnel (perfor- } \\
\text { mance bias) } \\
\text { All outcomes }\end{array}$ & Unclear risk & Insufficient information provided in the report \\
\hline $\begin{array}{l}\text { Blinding of outcome as- } \\
\text { sessment (detection bias) } \\
\text { All outcomes }\end{array}$ & Low risk & Outcome of interest (mode of delivery) objective \\
\hline $\begin{array}{l}\text { Baseline characteristics } \\
\text { similar? }\end{array}$ & Low risk & $\begin{array}{l}\text { The two groups of women (those who received the brochures and those who } \\
\text { used the decision aid) were similar in all demographic, health insurance sta- } \\
\text { tus, birth intention and obstetric history variables }\end{array}$ \\
\hline $\begin{array}{l}\text { Baseline outcome mea- } \\
\text { surements similar? }\end{array}$ & Low risk & Stratified by women's motivation to attempt vaginal birth \\
\hline $\begin{array}{l}\text { Incomplete outcome data } \\
\text { (attrition bias) } \\
\text { All outcomes }\end{array}$ & Low risk & No missing data on outcome measures \\
\hline $\begin{array}{l}\text { Selective reporting (re- } \\
\text { porting bias) }\end{array}$ & Low risk & Data on all prespecified outcomes reported \\
\hline $\begin{array}{l}\text { Protected against contam- } \\
\text { ination? }\end{array}$ & Unclear risk & Insufficient information available to assess likelihood of contamination \\
\hline Other bias & Low risk & No evidence of other bias \\
\hline
\end{tabular}

Hemminki 2008

\begin{tabular}{ll}
\hline Methods & Cluster-randomised trial \\
\hline Participants & Public health nurses in maternity health centres, Helsinki Finland \\
\hline Interventions & Training of public health nurses to focus more on mode of delivery in childbirth classes \\
\hline
\end{tabular}


Hemminki 2008 (Continued)

Outcomes Mode of delivery, pain relief, labour induction, use of oxytocin, foetal electronic surveillance, Apgar score, care in neonatal or intensive care units and perinatal and infant deaths

Notes

Pilot testing, no sample size calculation and cluster accommodation. Intervention did not succeed

Baseline (control group) CS rate: $12 \%$

Date of study: 2002 to 2003

Funding: National Research and Development Centre for Welfare and Health (STAKES), Helsinki, Finland

Conflict of interest: the authors declare that they have no known conflict of interests.

\section{Risk of bias}

\begin{tabular}{|c|c|c|}
\hline Bias & Authors' judgement & Support for judgement \\
\hline $\begin{array}{l}\text { Random sequence genera- } \\
\text { tion (selection bias) }\end{array}$ & Low risk & "Randomly allocated...on the throw of a dice" \\
\hline $\begin{array}{l}\text { Allocation concealment } \\
\text { (selection bias) }\end{array}$ & Unclear risk & Insufficient information provided in the report \\
\hline $\begin{array}{l}\text { Blinding of participants } \\
\text { and personnel (perfor- } \\
\text { mance bias) } \\
\text { All outcomes }\end{array}$ & Unclear risk & Insufficient information provided in the report \\
\hline $\begin{array}{l}\text { Blinding of outcome as- } \\
\text { sessment (detection bias) } \\
\text { All outcomes }\end{array}$ & Low risk & Main outcome of interest (mode of delivery) objective \\
\hline $\begin{array}{l}\text { Baseline characteristics } \\
\text { similar? }\end{array}$ & Low risk & $\begin{array}{l}\text { "Measured by women's background characteristics, the cluster randomisation } \\
\text { succeeded relatively well...with the exception of marital status, the pregnant } \\
\text { women's background characteristics were very similar." There were no differ- } \\
\text { ences in distribution of the number of previous pregnancies }\end{array}$ \\
\hline $\begin{array}{l}\text { Baseline outcome mea- } \\
\text { surements similar? }\end{array}$ & Unclear risk & Insufficient information provided in the report \\
\hline $\begin{array}{l}\text { Incomplete outcome data } \\
\text { (attrition bias) } \\
\text { All outcomes }\end{array}$ & High risk & High dropout in intervention group \\
\hline $\begin{array}{l}\text { Selective reporting (re- } \\
\text { porting bias) }\end{array}$ & Unclear risk & Insufficient information provided in the report \\
\hline $\begin{array}{l}\text { Protected against contam- } \\
\text { ination? }\end{array}$ & Low risk & Childbirth classes only provided to invited health workers \\
\hline Other bias & High risk & No a priori sample size calculation \\
\hline
\end{tabular}

Keeler 1996

Methods Interrupted time series study


Keeler 1996 (Continued)

Participants USA

11,767 deliveries - 5255 cases for the 12 months before and 6515 cases for the 12 months afterwards

\begin{tabular}{ll}
\hline Interventions & Equalising physician fees for vaginal and caesarean delivery \\
\hline Outcomes & Rate of caesarean deliveries, vaginal breech deliveries, caesarean deliveries due to breech \\
\hline Notes & Baseline (control group) CS rate: $25.3 \%$ \\
& Date of study: not reported (data set used - 12 months before and 12 months after May 1993) \\
& Funding: Agency for Health Care Policy and Research (AHCPR\#282-90-0039) \\
& Conflict of interest: not stated \\
\hline
\end{tabular}

\section{Risk of bias}

\begin{tabular}{|c|c|c|}
\hline Bias & Authors' judgement & Support for judgement \\
\hline $\begin{array}{l}\text { Intervention independent } \\
\text { of other changes? }\end{array}$ & Unclear risk & No information provided in the report \\
\hline $\begin{array}{l}\text { Shape of the intervention } \\
\text { effect pre-specified? }\end{array}$ & Low risk & Point of analysis is point of intervention \\
\hline $\begin{array}{l}\text { Intervention unlikely to af- } \\
\text { fect data collection? }\end{array}$ & Unclear risk & Insufficient information provided in the report \\
\hline $\begin{array}{l}\text { Incomplete outcome data } \\
\text { (attrition bias) } \\
\text { All outcomes }\end{array}$ & Unclear risk & Missing outcome data not reported in the report \\
\hline $\begin{array}{l}\text { Selective reporting (re- } \\
\text { porting bias) }\end{array}$ & Low risk & All relevant outcomes are reported \\
\hline $\begin{array}{l}\text { Knowledge of the allo- } \\
\text { cated interventions ade- } \\
\text { quately prevented during } \\
\text { the study? }\end{array}$ & Low risk & Main outcome of interest (mode of delivery) objective \\
\hline Other bias & High risk & Insufficient data available for appropriate reanalysis \\
\hline
\end{tabular}

Liang 2004

\begin{tabular}{ll}
\hline Methods & $\begin{array}{l}\text { Interrupted time series analysis } \\
\text { Comparisons of caesarean rates between 1993-96 and 1997-2000 }\end{array}$ \\
\hline Participants & Taiwan \\
\hline Interventions & Pregnant women in labour \\
\hline Outcomes & Total, primary and repeat caesarean rates, Apgar scores \\
\hline
\end{tabular}


Liang 2004 (Continued)

$\begin{array}{ll}\text { Notes } & \text { Baseline (control group) CS rate: } 37 \% \\ & \text { Date of study: } 1993 \text { to } 2000 \\ & \text { Funding: not reported } \\ \text { Conflict of interest: } \text { not reported }\end{array}$

\section{Risk of bias}

\begin{tabular}{|c|c|c|}
\hline Bias & Authors' judgement & Support for judgement \\
\hline $\begin{array}{l}\text { Intervention independent } \\
\text { of other changes? }\end{array}$ & Unclear risk & No statement of another intervention occurring concurrently \\
\hline $\begin{array}{l}\text { Shape of the intervention } \\
\text { effect pre-specified? }\end{array}$ & Low risk & Point of analysis is point of intervention \\
\hline $\begin{array}{l}\text { Intervention unlikely to af- } \\
\text { fect data collection? }\end{array}$ & Low risk & Data collection separate from intervention \\
\hline $\begin{array}{l}\text { Incomplete outcome data } \\
\text { (attrition bias) } \\
\text { All outcomes }\end{array}$ & Unclear risk & Unable to assess if all outcome data included \\
\hline $\begin{array}{l}\text { Selective reporting (re- } \\
\text { porting bias) }\end{array}$ & Low risk & Data on all relevant outcomes reported \\
\hline $\begin{array}{l}\text { Knowledge of the allo- } \\
\text { cated interventions ade- } \\
\text { quately prevented during } \\
\text { the study? }\end{array}$ & Low risk & Main outcome of interest (mode of delivery) objective \\
\hline Other bias & Low risk & No evidence of other bias \\
\hline
\end{tabular}

Lo 2008

\begin{tabular}{ll}
\hline Methods & Interrupted time series study \\
\hline Participants & Taiwan \\
& Pregnant women (2001 to 2005) \\
\hline Interventions & $\begin{array}{l}\text { Financial interventions: } 1 \text { ) Increase in vaginal birth after caesarean (VBAC) fee to the same level as cae- } \\
\text { sarean section (April 2003); 2) Increase in vaginal birth fee to that of caesarean section (May 2005) }\end{array}$ \\
\hline Outcomes & Caesarean section and VBAC rates \\
\hline Notes & Baseline (control group) CS rate: $29 \%$ \\
& Date of study: 2001 to 2005 \\
& Funding: not stated \\
& Conflict of interest: not stated \\
\hline
\end{tabular}

\section{Risk of bias}

Non-clinical interventions for reducing unnecessary caesarean section (Review) 
Lo 2008 (Continued)

\begin{tabular}{lll} 
Bias & Authors' judgement & Support for judgement \\
\hline $\begin{array}{l}\text { Intervention independent } \\
\text { of other changes? }\end{array}$ & Unclear risk & Insufficient information provided in the report
\end{tabular}

Shape of the intervention Low risk Point of analysis is the point of intervention

effect pre-specified?

Intervention unlikely to af- Low risk Considered unlikely to affect data collection

fect data collection?

Incomplete outcome data Unclear risk No reference to missing data

(attrition bias)

All outcomes

Selective reporting (re- Low risk Data on all prespecified outcomes reported porting bias)

Knowledge of the allo- Low risk Main outcome of interest (mode of delivery) objective

cated interventions ade-

quately prevented during

the study?

Other bias Low risk No evidence of other bias

Lomas 1991

\begin{tabular}{ll}
\hline Methods & Cluster-randomised trial \\
\hline Participants & Canada \\
& 76 physicians in 16 community hospitals \\
\hline
\end{tabular}

Interventions $\quad$ Interventions: (1) audit and feedback + distribution of educational materials; (2) Local opinion leaders + distribution of educational materials

Control: distribution of educational materials

Outcomes Trial of labour rates, vaginal births, maternal and neonatal morbidity

$\begin{array}{ll}\text { Notes } & \text { Baseline (control group) CS rate: } 20 \% \\ & \text { Date of study: } 1988 \text { to } 1989 \\ & \text { Funding: National Health Research and Development Programme of Health and Welfare Canada } \\ & \text { Conflict of interest: not stated }\end{array}$

\section{Risk of bias}

\begin{tabular}{lll}
\hline Bias & Authors' judgement & Support for judgement \\
\hline $\begin{array}{l}\text { Random sequence genera- } \\
\text { tion (selection bias) }\end{array}$ & Unclear risk & Not specified in the paper "randomly selected and assigned" \\
\hline $\begin{array}{l}\text { Allocation concealment } \\
\text { (selection bias) }\end{array}$ & Unclear risk & Insufficient information provided in the report \\
\hline
\end{tabular}


Lomas 1991 (Continued)
Blinding of participants
Unclear risk
Insufficient information provided in the report and personnel (performance bias)

All outcomes

\begin{tabular}{|c|c|c|}
\hline $\begin{array}{l}\text { Blinding of outcome as- } \\
\text { sessment (detection bias) } \\
\text { All outcomes }\end{array}$ & Low risk & Main outcome of interest (mode of delivery) objective \\
\hline $\begin{array}{l}\text { Baseline characteristics } \\
\text { similar? }\end{array}$ & Low risk & No significant differences between groups \\
\hline $\begin{array}{l}\text { Baseline outcome mea- } \\
\text { surements similar? }\end{array}$ & Low risk & $\begin{array}{l}\text { "Small difference in the overall caesarean section and VBAC rates prior to the } \\
\text { study were not statistically significant" }\end{array}$ \\
\hline $\begin{array}{l}\text { Incomplete outcome data } \\
\text { (attrition bias) } \\
\text { All outcomes }\end{array}$ & Unclear risk & Unclear from the study report \\
\hline $\begin{array}{l}\text { Protected against contam- } \\
\text { ination? }\end{array}$ & Low risk & Unlikely: unit of allocation is community hospital \\
\hline Other bias & High risk & Unit of analysis errors \\
\hline
\end{tabular}

Masoumi 2016

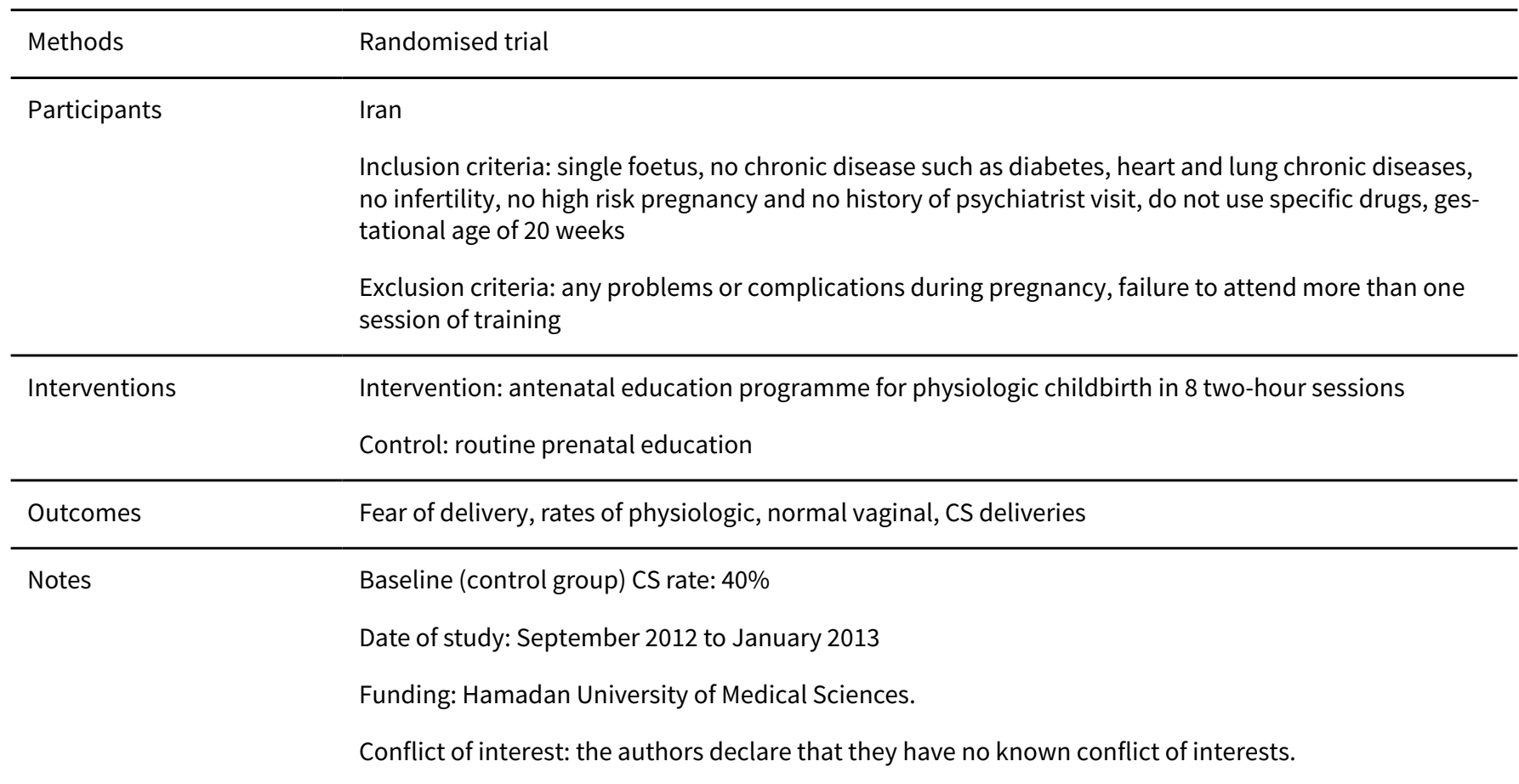

\section{Risk of bias}


Masoumi 2016 (Continued) $\begin{array}{ll}\begin{array}{l}\text { Random sequence genera- } \\ \text { tion (selection bias) }\end{array} & \text { " } 160 \text { people entered the study and were divided into two equal groups using } \\ \text { the table of random numbers" }\end{array}$

$\begin{array}{ll}\begin{array}{l}\text { Allocation concealment } \quad \text { Low risk } \\ \text { (selection bias) }\end{array} & \text { "In inside of } 160 \text { envelopes, A and B letters were written. The eligible persons } \\ & \text { were given the envelopes respectively. After opening the envelope, the type of } \\ \text { groups was found" }\end{array}$

Blinding of participants Unclear risk Insufficient information provided in the report
and personnel (performance bias)

All outcomes

\begin{tabular}{|c|c|c|}
\hline $\begin{array}{l}\text { Blinding of outcome as- } \\
\text { sessment (detection bias) } \\
\text { All outcomes }\end{array}$ & Low risk & Main outcome of interest (mode of delivery) objective \\
\hline $\begin{array}{l}\text { Baseline characteristics } \\
\text { similar? }\end{array}$ & Low risk & "Baseline characteristics of women were similar in both groups" \\
\hline $\begin{array}{l}\text { Baseline outcome mea- } \\
\text { surements similar? }\end{array}$ & Low risk & No important differences present \\
\hline $\begin{array}{l}\text { Incomplete outcome data } \\
\text { (attrition bias) } \\
\text { All outcomes }\end{array}$ & Low risk & Proportion of missing data unlikely to change main results \\
\hline $\begin{array}{l}\text { Selective reporting (re- } \\
\text { porting bias) }\end{array}$ & Low risk & $\begin{array}{l}\text { All relevant outcomes in the methods section are reported in the results sec- } \\
\text { tion }\end{array}$ \\
\hline $\begin{array}{l}\text { Protected against contam- } \\
\text { ination? }\end{array}$ & Unclear risk & Allocation was by individual patients (cannot rule out contamination) \\
\hline Other bias & Low risk & No evidence of other risk of bias \\
\hline
\end{tabular}

Mohammadi 2012

\begin{tabular}{ll}
\hline Methods & Retrospective, before-after study (reanalysed as an interrupted time series study) \\
\hline Participants & Iran \\
& 3494 pregnant women in General hospital, Tehran, Iran from May 2005 to December 2005 \\
\hline Interventions & $\begin{array}{l}\text { Clinical audit and feedback process; review of random sample of caesarean section patients for indica- } \\
\text { tion with financial incentive to practitioners who met the criteria }\end{array}$ \\
\hline Outcomes & Caesarean section rates \\
\hline Notes & Baseline (control group) CS rate: $40 \%$ \\
Date of study: 2004 to 2005 \\
Funding: Faculty of Medicine, Uppsala University \\
Conflict of interest: the authors declare that they have no known conflict of interests.
\end{tabular}

\section{Risk of bias}

Non-clinical interventions for reducing unnecessary caesarean section (Review) 
Mohammadi 2012 (Continued)

\begin{tabular}{lll} 
Bias & Authors' judgement & Support for judgement \\
\hline $\begin{array}{l}\text { Intervention independent } \\
\text { of other changes? }\end{array}$ & Unclear risk & Insufficient information provided in the report \\
\hline $\begin{array}{l}\text { Shape of the intervention } \\
\text { effect pre-specified? }\end{array}$ & Low risk & Point of analysis is point of intervention \\
\hline
\end{tabular}

Intervention unlikely to af- Low risk Retrospective cohort study of all deliveries
fect data collection?

Incomplete outcome data $\quad$ Unclear risk $\quad$ Missing data not reported
(attrition bias)
All outcomes

Selective reporting (re- Low risk $\quad$ All relevant data reported
porting bias)

\begin{tabular}{|c|c|c|}
\hline $\begin{array}{l}\text { Knowledge of the allo- } \\
\text { cated interventions ade- } \\
\text { quately prevented during } \\
\text { the study? }\end{array}$ & Low risk & Main outcome of interest (mode of delivery) objective \\
\hline Other bias & Low risk & No evidence of other bias \\
\hline
\end{tabular}

\section{Montgomery 2007}

\begin{tabular}{ll}
\hline Methods & Randomised trial \\
\hline Participants & UK \\
& $\begin{array}{l}742 \text { pregnant women from } 4 \text { maternity units with one previous lower segment caesarean section. Re- } \\
\text { cruited by research midwife at antenatal clinic } 10 \text { to } 20 \text { weeks gestation }\end{array}$ \\
\hline Interventions & $\begin{array}{l}\text { Two patient decision-aids: information programme providing information on the outcomes associated } \\
\text { with planned vaginal delivery, elective caesarean section and emergency caesarean section; and a de- } \\
\text { cision analysis containing information on descriptions of outcomes for mother and baby of each deliv- } \\
\text { ery method and women are asked to consider a value to these outcomes. This provides a recommend- } \\
\text { ed 'preferred option' based on maximised expected utility }\end{array}$ \\
\hline Putcomes & Secondary: anxiety, knowledge of the decisional conflict scale and satisfaction \\
\hline Notes & $\begin{array}{l}\text { Baseline (control group) CS rate: } 24 \% \\
\text { Date of study: May } 2004 \text { to August } 2006 \\
\text { Funding: BUPA Foundation; UK Department of Health National Coordinating Centre for Research Ca- } \\
\text { pacity Development } \\
\text { Conflict of interest: the authors declare that they have no known conflict of interests }\end{array}$ \\
\hline
\end{tabular}

\section{Risk of bias}


Montgomery 2007 (Continued)

\begin{tabular}{lll}
$\begin{array}{l}\text { Random sequence genera- } \\
\text { tion (selection bias) }\end{array}$ & Low risk & $\begin{array}{l}\text { "One member of the of the study team generated the randomisation sequence } \\
\text { by computer..." }\end{array}$ \\
\hline $\begin{array}{l}\text { Allocation concealment } \\
\text { (selection bias) }\end{array}$ & Low risk & $\begin{array}{l}\text { "...another member of staff with no involvement in the trial performed the al- } \\
\text { location" }\end{array}$ \\
\hline $\begin{array}{l}\text { Blinding of participants } \\
\text { and personnel (perfor- } \\
\begin{array}{l}\text { mance bias) } \\
\text { All outcomes }\end{array}\end{array}$ & Unclear risk & No information provided in the report \\
\hline
\end{tabular}

\begin{tabular}{lll}
\hline $\begin{array}{l}\text { Blinding of outcome as- } \\
\text { sessment (detection bias) } \\
\text { All outcomes }\end{array}$ & Low risk & Main outcome of interest (mode of delivery) objective \\
\hline $\begin{array}{l}\text { Baseline characteristics } \\
\text { similar? }\end{array}$ & Unclear risk & Insufficient information in the report \\
\hline $\begin{array}{l}\text { Baseline outcome mea- } \\
\text { surements similar? }\end{array}$ & Low risk & $\begin{array}{l}\text { Outcomes measured before intervention and no important differences report- } \\
\text { ed }\end{array}$
\end{tabular}

\begin{tabular}{lll}
\hline $\begin{array}{l}\text { Incomplete outcome data } \\
\text { (attrition bias) }\end{array}$ & Low risk & Proportion of missing data similar for each group \\
All outcomes & \\
\hline $\begin{array}{l}\text { Selective reporting (re- } \\
\text { porting bias) }\end{array}$ & Low risk & Data on all prespecified outcomes reported \\
\hline
\end{tabular}

Protected against contam- Low risk Decision aids only provided to those women randomised to that arm
ination?

\begin{tabular}{ll}
\hline Other bias $\quad$ Low risk $\quad$ No evidence of other bias \\
\hline
\end{tabular}

Navaee 2015

\begin{tabular}{ll}
\hline Methods & Randomised trial \\
\hline Participants & Iran \\
& $\begin{array}{l}\text { Inclusion criteria: no experience of acute psychological emotions, delivery and childbirth fear score }> \\
28, \text { primiparous, single pregnancy, gestational age of 34-36 weeks, age of 18-35 years, no history of in- } \\
\text { fertility, no indication for CS, and not having passed educational course for delivery methods }\end{array}$
\end{tabular}

\begin{tabular}{ll}
\hline Interventions & Role play education versus standard education using lectures \\
\hline Outcomes & Fear of natural delivery, mode of delivery \\
\hline Notes & Baseline (control group) CS rate: $56.2 \%$ \\
& Date of study: not reported. \\
& Funding: Mashhad University of Medical Sciences, Iran \\
& Conflict of interest: the authors declare that they have no known conflict of interests.
\end{tabular}

\section{Risk of bias}

Non-clinical interventions for reducing unnecessary caesarean section (Review) 
Navaee 2015 (Continued)

\begin{tabular}{|c|c|c|}
\hline Bias & Authors' judgement & Support for judgement \\
\hline $\begin{array}{l}\text { Random sequence genera- } \\
\text { tion (selection bias) }\end{array}$ & Unclear risk & No information provided in the report \\
\hline $\begin{array}{l}\text { Allocation concealment } \\
\text { (selection bias) }\end{array}$ & Unclear risk & $\begin{array}{l}\text { The unit of allocation was health centre (however, no information was report- } \\
\text { ed on allocation concealment) }\end{array}$ \\
\hline $\begin{array}{l}\text { Blinding of participants } \\
\text { and personnel (perfor- } \\
\text { mance bias) } \\
\text { All outcomes }\end{array}$ & Unclear risk & Insufficient information provided in the report \\
\hline $\begin{array}{l}\text { Blinding of outcome as- } \\
\text { sessment (detection bias) } \\
\text { All outcomes }\end{array}$ & Low risk & Main outcome of interest (VBAC) objective \\
\hline $\begin{array}{l}\text { Baseline characteristics } \\
\text { similar? }\end{array}$ & Low risk & $\begin{array}{l}\text { There were no differences in baseline characteristics between study groups at } \\
\text { baseline }\end{array}$ \\
\hline $\begin{array}{l}\text { Baseline outcome mea- } \\
\text { surements similar? }\end{array}$ & Low risk & $\begin{array}{l}\text { There were no differences in outcome measures at baseline (Table } 1 \text { in the ar- } \\
\text { ticle) }\end{array}$ \\
\hline $\begin{array}{l}\text { Incomplete outcome data } \\
\text { (attrition bias) } \\
\text { All outcomes }\end{array}$ & Unclear risk & Insufficient information provided in the report \\
\hline $\begin{array}{l}\text { Selective reporting (re- } \\
\text { porting bias) }\end{array}$ & Low risk & Data on all prespecified outcomes reported \\
\hline Other bias & Low risk & No evidence of other bias \\
\hline
\end{tabular}

\section{Poma 1998}

\begin{tabular}{ll}
\hline Methods & Interrupted time series study \\
\hline Participants & USA \\
& Community hospital obstetric unit; women delivering over 6-year period 1991 to 1996 \\
\hline Interventions & $\begin{array}{l}\text { Peer review and feedback regarding use of practice guidelines } \\
\text { 24-hour in-house physician coverage }\end{array}$ \\
\hline Outcomes & Total, primary and repeat caesarean section rate, perinatal morbidity and mortality \\
\hline Notes & Baseline (control group) CS rate: $20.7 \%$ \\
& Date of study: January 1991 to December 1996 \\
& Funding: not stated \\
& Conflict of interest: not stated
\end{tabular}


Poma 1998 (Continued)

Risk of bias

\begin{tabular}{|c|c|c|}
\hline Bias & Authors' judgement & Support for judgement \\
\hline $\begin{array}{l}\text { Intervention independent } \\
\text { of other changes? }\end{array}$ & Unclear risk & Insufficient information provided in the report \\
\hline $\begin{array}{l}\text { Shape of the intervention } \\
\text { effect pre-specified? }\end{array}$ & Low risk & Point of analysis is point of intervention \\
\hline $\begin{array}{l}\text { Intervention unlikely to af- } \\
\text { fect data collection? }\end{array}$ & Unclear risk & No distinction between intervention and records collected \\
\hline $\begin{array}{l}\text { Incomplete outcome data } \\
\text { (attrition bias) } \\
\text { All outcomes }\end{array}$ & Unclear risk & No description of missing data \\
\hline $\begin{array}{l}\text { Selective reporting (re- } \\
\text { porting bias) }\end{array}$ & Low risk & Data on all prespecified outcomes reported \\
\hline $\begin{array}{l}\text { Knowledge of the allo- } \\
\text { cated interventions ade- } \\
\text { quately prevented during } \\
\text { the study? }\end{array}$ & Low risk & Main outcome of interest (mode of delivery) objective \\
\hline Other bias & Low risk & No evidence of other bias \\
\hline
\end{tabular}

Rosenstein 2015

\begin{tabular}{ll}
\hline Methods & Interrupted time series study \\
\hline Participants & USA \\
& $\begin{array}{l}\text { Study period: } 2005 \text { and } 2014: \text { In } 2011, \text { privately insured women changed from a private practice mod- } \\
\text { el to one that included 24-hour midwifery and labourist coverage. Primary caesarean delivery rates } \\
\text { among nulliparous, term, singleton, vertex women and VBAC rates among women with prior caesarean } \\
\text { delivery were compared before and after the change }\end{array}$
\end{tabular}

\begin{tabular}{ll}
\hline Interventions & Expanded access to collaborative 24-hour midwifery-labourist care model \\
\hline Outcomes & Primary caesarean delivery and VBAC \\
\hline Notes & Baseline (control group) CS rate: $31.7 \%$ \\
& Date of study: 2005 to 2014 \\
& Funding: National Institute of Child Health and Human Development (Grant \# HD01262); National Cen- \\
& ter for Advancing Translational Sciences (Grant \# UCSF-CTSI UL1 TR000004); and the non-profit Prima \\
& Medical Foundation \\
& Conflict of interest: the authors declare that they have no known conflict of interests.
\end{tabular}

\section{Risk of bias}

Bias Authors' judgement Support for judgement


Rosenstein 2015 (Continued)

Intervention independent Low risk "We cannot be certain whether other factors could have led to the decrease in of other changes? rates, although there were no other official hospital policies that took effect during this time."

$\begin{array}{ll}\begin{array}{l}\text { Shape of the intervention } \\ \text { effect pre-specified? }\end{array} & \text { Low risk } \\ \end{array}$

Intervention unlikely to af- Low risk fect data collection?

Sources and methods of data collection were the same before and after the intervention

Incomplete outcome data Unclear risk Not specified in the report
(attrition bias)

(attrition bias)

All outcomes

\begin{tabular}{ll}
\hline $\begin{array}{l}\text { Selective reporting (re- } \\
\text { porting bias) }\end{array}$ & Low risk \\
\end{tabular}

\begin{tabular}{|c|c|c|}
\hline $\begin{array}{l}\text { Knowledge of the allo- } \\
\text { cated interventions ade- } \\
\text { quately prevented during } \\
\text { the study? }\end{array}$ & Low risk & Main outcome of interest (mode of delivery) objective \\
\hline Other bias & Low risk & No evidence of other bias \\
\hline
\end{tabular}

Rouhe 2013

\begin{tabular}{ll}
\hline Methods & Randomised trial \\
\hline Participants & Finland \\
& $\begin{array}{l}\text { Inclusion criteria: nulliparous women with severe fear of birth according to the Wijma Delivery Ex- } \\
\text { pectancy Questionnaire A (prenatal version) (W-DEQ A) (REF 21) }\end{array}$ \\
\hline
\end{tabular}

Interventions Intervention: psychoeducative group sessions led by a psychologist

Women in the control group received a letter in which they were advised to discuss their fear of childbirth in their primary maternity healthcare unit. When needed, primary health care referred fearful women to a special maternity care unit

\begin{tabular}{ll}
\hline Outcomes & Mode of delivery, life satisfaction and general well-being, costs, duration of labour and delivery, post- \\
partum haemorrhage, usage of epidural or spinal analgesia, birthweight and umbilical arterial pH of \\
the new born, Apgar scores, and interventions during the third stage of labour (suturing or surgical \\
evacuation of placenta or membranes postpartum)
\end{tabular}

Notes $\quad$ Baseline (control group) CS rate: $32.5 \%$

Date of study: October 2007 to August 2009

Funding: Emil Aaltonen Foundation and the Signe and Ane Gyllenberg Foundation

Conflict of interest: the authors declare that they have no known conflict of interests.

\section{Risk of bias}

Bias Authors' judgement Support for judgement


Rouhe 2013 (Continued)

$\begin{array}{ll}\begin{array}{l}\text { Random sequence genera- } \\ \text { tion (selection bias) }\end{array} & \begin{array}{l}\text { Method of allocation sequence generation not reported (Women were ran- } \\ \text { domised, by one of the researchers, to the intervention or control group in the } \\ \text { proportion of } 1: 2 \text { in balanced blocks of 18) }\end{array}\end{array}$

\begin{tabular}{|c|c|c|}
\hline $\begin{array}{l}\text { Allocation concealment } \\
\text { (selection bias) }\end{array}$ & Low risk & Sealed opaque envelopes used \\
\hline $\begin{array}{l}\text { Blinding of participants } \\
\text { and personnel (perfor- } \\
\text { mance bias) } \\
\text { All outcomes }\end{array}$ & Unclear risk & No information provided in the report \\
\hline $\begin{array}{l}\text { Blinding of outcome as- } \\
\text { sessment (detection bias) } \\
\text { All outcomes }\end{array}$ & Low risk & Main outcomes (mode of delivery) objective \\
\hline $\begin{array}{l}\text { Baseline characteristics } \\
\text { similar? }\end{array}$ & Low risk & $\begin{array}{l}\text { Table } 3 \text { in the article: There were no significant differences between study } \\
\text { groups in age, social status, education, previous pregnancies or marital status }\end{array}$ \\
\hline $\begin{array}{l}\text { Baseline outcome mea- } \\
\text { surements similar? }\end{array}$ & Unclear risk & No information provided \\
\hline $\begin{array}{l}\text { Incomplete outcome data } \\
\text { (attrition bias) } \\
\text { All outcomes }\end{array}$ & Low risk & No missing data \\
\hline $\begin{array}{l}\text { Selective reporting (re- } \\
\text { porting bias) }\end{array}$ & Low risk & Data on all prespecified outcomes reported \\
\hline $\begin{array}{l}\text { Protected against contam- } \\
\text { ination? }\end{array}$ & Unclear risk & Insufficient information available to assess likelihood of contamination \\
\hline Other bias & Low risk & No evidence of other bias \\
\hline
\end{tabular}

\section{Runmei 2012}

\begin{tabular}{ll}
\hline Methods & Retrospective before-after study \\
& Reanalysed as an interrupted time series study \\
\hline Participants & China \\
& 25,280 pregnant women at a Regional referral centre, Yunnan, China from January 2005 to December \\
& 2011 \\
\hline
\end{tabular}

Interventions Stage 1 (Jan 2005 to Dec 2006): educational programme for hospital staff

Stage 2 (Jan to June 2007): monitoring of risk-adjusted caesarean section rates

Stage 3 (Jan 2005 to Dec 2011): monitoring of neonatal outcomes

\begin{tabular}{ll}
\hline Outcomes & Caesarean section rate, neonatal outcomes \\
\hline Notes & Only first two stages targeting caesarean sections were considered for analysis \\
& Baseline (control group) CS rate: $54.8 \%$
\end{tabular}


Funding: Yunnan Science and Technology Committee, Yunnan Province Government (research grant 2009CA006)

Conflict of interest: the authors declare that they have no known conflict of interests.

\section{Risk of bias}

\begin{tabular}{|c|c|c|}
\hline Bias & Authors' judgement & Support for judgement \\
\hline $\begin{array}{l}\text { Intervention independent } \\
\text { of other changes? }\end{array}$ & Unclear risk & Insufficient information provided in the report \\
\hline $\begin{array}{l}\text { Shape of the intervention } \\
\text { effect pre-specified? }\end{array}$ & Low risk & Point of analysis is point of intervention \\
\hline $\begin{array}{l}\text { Intervention unlikely to af- } \\
\text { fect data collection? }\end{array}$ & Low risk & Retrospective cohort study of all deliveries \\
\hline $\begin{array}{l}\text { Incomplete outcome data } \\
\text { (attrition bias) } \\
\text { All outcomes }\end{array}$ & Unclear risk & Insufficient information provided in the report \\
\hline $\begin{array}{l}\text { Selective reporting (re- } \\
\text { porting bias) }\end{array}$ & Low risk & Data on all prespecified outcomes reported \\
\hline $\begin{array}{l}\text { Knowledge of the allo- } \\
\text { cated interventions ade- } \\
\text { quately prevented during } \\
\text { the study? }\end{array}$ & Low risk & Main outcome of interest (mode of delivery) objective \\
\hline Other bias & Low risk & No evidence of other bias \\
\hline
\end{tabular}

Saisto 2001

\begin{tabular}{ll}
\hline Methods & Randomised trial \\
\hline Participants & $\begin{array}{l}\text { Finland } \\
\text { Physically healthy pregnant women with low obstetric risk and a diagnosis of fear of childbirth } \\
\text { Exclusion criteria: contraindication to vaginal delivery (2 previous caesareans or vertical incision in pre- } \\
\text { vious caesarean) }\end{array}$ \\
\hline Interventions & $\begin{array}{l}\text { Intensive group therapy with trained obstetrician in cognitive behavioural therapy and childbirth psy- } \\
\text { chology }\end{array}$ \\
\hline Outcomes & $\begin{array}{l}\text { Requests for caesarean delivery at } 38 \text { weeks pregnancy } \\
\text { Reporting level of anxiety, depression and concerns using multiple scales at 24 and } 36 \text { weeks }\end{array}$ \\
\hline Notes & Baseline (control group) CS rate: $15 \%$ \\
& $\begin{array}{l}\text { Date of study: August } 1996 \text { to July } 1999 \\
\text { Funding: Signe and Ane Gyllenberg Foundation, the Emil Aaltonen Foundation, Helsinki University Cen- } \\
\text { tral Hospital, and the Academy of Finland }\end{array}$
\end{tabular}


Saisto 2001 (Continued)

Conflict of interest: not stated

\section{Risk of bias}

\begin{tabular}{|c|c|c|}
\hline Bias & Authors' judgement & Support for judgement \\
\hline $\begin{array}{l}\text { Random sequence genera- } \\
\text { tion (selection bias) }\end{array}$ & Unclear risk & No information provided in the report \\
\hline $\begin{array}{l}\text { Allocation concealment } \\
\text { (selection bias) }\end{array}$ & Low risk & $\begin{array}{l}\text { "...randomly assigned to groups in balanced blocks of } 20 \text { by sealed opaque en- } \\
\text { velopes" }\end{array}$ \\
\hline $\begin{array}{l}\text { Blinding of participants } \\
\text { and personnel (perfor- } \\
\text { mance bias) } \\
\text { All outcomes }\end{array}$ & Unclear risk & Insufficient information provided in the report \\
\hline $\begin{array}{l}\text { Blinding of outcome as- } \\
\text { sessment (detection bias) } \\
\text { All outcomes }\end{array}$ & Unclear risk & Insufficient information provided in the report \\
\hline $\begin{array}{l}\text { Baseline characteristics } \\
\text { similar? }\end{array}$ & Low risk & Measured and no significant differences between groups found \\
\hline $\begin{array}{l}\text { Baseline outcome mea- } \\
\text { surements similar? }\end{array}$ & Low risk & Measured and no significant differences between groups found \\
\hline $\begin{array}{l}\text { Incomplete outcome data } \\
\text { (attrition bias) } \\
\text { All outcomes }\end{array}$ & Low risk & Proportion of missing data similar in study groups \\
\hline $\begin{array}{l}\text { Selective reporting (re- } \\
\text { porting bias) }\end{array}$ & Low risk & No evidence of selective reporting \\
\hline $\begin{array}{l}\text { Protected against contam- } \\
\text { ination? }\end{array}$ & Low risk & No evidence of group contamination \\
\hline Other bias & Low risk & No evidence of other bias \\
\hline
\end{tabular}

\section{Scarella 2011}

\begin{tabular}{ll}
\hline Methods & Interrupted time series study \\
\hline Participants & Chile \\
& $\begin{array}{l}4813 \text { pregnant women at a regional health centre, admitted for spontaneous labour or pregnancy in- } \\
\text { terruption }\end{array}$ \\
& Excluded deliveries with newborns $<500 \mathrm{~g}$, deliveries by private physicians \\
\hline Interventions & Audit and feedback \\
\hline Outcomes & Caesarean section rate, neonatal outcomes \\
\hline Notes & Baseline (control group) CS rate: $36.8 \%$ \\
& Date of study: March 2007 to November 2008 \\
\hline
\end{tabular}


Scarella 2011 (Continued)

\section{Funding: not stated}

Conflict of interest: the authors declare that they have no known conflict of interests.

\section{Risk of bias}

\begin{tabular}{|c|c|c|}
\hline Bias & Authors' judgement & Support for judgement \\
\hline $\begin{array}{l}\text { Intervention independent } \\
\text { of other changes? }\end{array}$ & Unclear risk & Insufficient information provided in the report \\
\hline $\begin{array}{l}\text { Shape of the intervention } \\
\text { effect pre-specified? }\end{array}$ & Low risk & Point of analysis is point of intervention \\
\hline $\begin{array}{l}\text { Intervention unlikely to af- } \\
\text { fect data collection? }\end{array}$ & Low risk & Insufficient information provided in the report \\
\hline $\begin{array}{l}\text { Incomplete outcome data } \\
\text { (attrition bias) } \\
\text { All outcomes }\end{array}$ & Unclear risk & Insufficient information provided in the report \\
\hline $\begin{array}{l}\text { Selective reporting (re- } \\
\text { porting bias) }\end{array}$ & Low risk & Data on all relevant outcomes reported \\
\hline $\begin{array}{l}\text { Knowledge of the allo- } \\
\text { cated interventions ade- } \\
\text { quately prevented during } \\
\text { the study? }\end{array}$ & Low risk & Main outcome of interest (mode of delivery) objective \\
\hline Other bias & Low risk & No evidence of other bias \\
\hline
\end{tabular}

\section{Sharifirad 2013}

\begin{tabular}{ll}
\hline Methods & Randomised trial \\
\hline Participants & Iran \\
& $\begin{array}{l}\text { Inclusion criteria: primiparous pregnant women in 28-32 pregnancy weeks who referred to private clin- } \\
\text { ics and were willing to use caesarean section; lack of obvious barriers and medical diagnosis for vaginal } \\
\text { delivery during sampling such as detectable medical causes; full consent and collaboration of pregnant } \\
\text { women and their husbands in order to participate in the intervention }\end{array}$ \\
\hline Interventions & Prenatal education for husbands of pregnant women \\
\hline Outcomes & Elective caesarian section rate; knowledge and attitudes \\
\hline Notes & Baseline (control group) CS rate: 50\% \\
Date of study: not stated & Funding: none \\
Conflict of interest: the authors declare that they have no known conflict of interests.
\end{tabular}

\section{Risk of bias}

Bias Authors' judgement Support for judgement


Sharifirad 2013 (Continued)
Random sequence genera-
Unclear risk
Randomised, but method of randomisation not mentioned tion (selection bias)

\begin{tabular}{lll}
\hline $\begin{array}{l}\text { Allocation concealment } \\
\text { (selection bias) }\end{array}$ & Unclear risk & No information provided in the report \\
\hline $\begin{array}{l}\text { Blinding of participants } \\
\text { and personnel (perfor- } \\
\text { mance bias) }\end{array}$ & Unclear risk & No information provided in the report \\
All outcomes & &
\end{tabular}

\begin{tabular}{|c|c|c|}
\hline $\begin{array}{l}\text { Blinding of outcome as- } \\
\text { sessment (detection bias) } \\
\text { All outcomes }\end{array}$ & Low risk & Objective outcome measure (caesarean delivery) \\
\hline $\begin{array}{l}\text { Baseline characteristics } \\
\text { similar? }\end{array}$ & Low risk & No significant difference between study groups \\
\hline
\end{tabular}

\begin{tabular}{|c|c|c|}
\hline $\begin{array}{l}\text { Baseline outcome mea- } \\
\text { surements similar? }\end{array}$ & Low risk & No significant difference between study groups \\
\hline $\begin{array}{l}\text { Incomplete outcome data } \\
\text { (attrition bias) } \\
\text { All outcomes }\end{array}$ & Low risk & No evidence of attrition bias \\
\hline $\begin{array}{l}\text { Selective reporting (re- } \\
\text { porting bias) }\end{array}$ & Low risk & All prespecified outcome data reported \\
\hline $\begin{array}{l}\text { Protected against contam- } \\
\text { ination? }\end{array}$ & Unclear risk & $\begin{array}{l}\text { No clear steps to prevent contamination (could have been possible if there was } \\
\text { communication between participants) }\end{array}$ \\
\hline Other bias & Low risk & No evidence of other bias \\
\hline
\end{tabular}

Shorten 2005

\begin{tabular}{ll}
\hline Methods & Randomised trial \\
\hline Participants & Australia \\
& $\begin{array}{l}\text { Inclusion criteria: pregnant women with } 1 \text { previous caesarean section and medically eligible for a trial } \\
\text { of vaginal birth }\end{array}$ \\
& $\begin{array}{l}\text { Exclusion criteria: more than } 1 \text { previous caesarean section; classical or unknown uterine scar; histo- } \\
\text { ry of uterine rupture or upper segment perforation; multiple pregnancy; and obstetric or medical con- } \\
\text { traindications to vaginal birth, or trial of vaginal birth or both in the current pregnancy }\end{array}$
\end{tabular}

\begin{tabular}{ll}
\hline Interventions & $\begin{array}{l}\text { Decision-aid booklet describing risks and benefits of elective repeat caesarean section and trial of } \\
\text { labour provided at } 28 \text { weeks gestation }\end{array}$
\end{tabular}

\begin{tabular}{ll}
\hline Outcomes & $\begin{array}{l}\text { Mode of delivery, level of knowledge, decisional conflict score, preference for mode of delivery at } 36 \\
\text { weeks and postnatal satisfaction }\end{array}$ \\
\hline Notes & Baseline (control group) CS rate: $30 \%$ \\
& Date of study: May 2001 to May 2003
\end{tabular}


Shorten 2005 (Continued)

Funding: MBF Research Grant, Sydney, The University of Wollongong New Researcher Grant Scheme, Wollongong, and NSW Midwives Association Research Scholarship, Sydney, New South Wales, Australia

Conflict of interest: not stated

\section{Risk of bias}

\begin{tabular}{|c|c|c|}
\hline Bias & Authors' judgement & Support for judgement \\
\hline $\begin{array}{l}\text { Random sequence genera- } \\
\text { tion (selection bias) }\end{array}$ & Low risk & $\begin{array}{l}\text { "Opaque envelopes containing a random allocation for each participant code } \\
\text { number were prepared by computer-based randomized generation" }\end{array}$ \\
\hline $\begin{array}{l}\text { Allocation concealment } \\
\text { (selection bias) }\end{array}$ & Low risk & $\begin{array}{l}\text { "Opaque envelopes containing a random allocation for each participant code } \\
\text { number were prepared by computer-based randomized generation" }\end{array}$ \\
\hline $\begin{array}{l}\text { Blinding of participants } \\
\text { and personnel (perfor- } \\
\text { mance bias) } \\
\text { All outcomes }\end{array}$ & Unclear risk & Insufficient information in the report \\
\hline $\begin{array}{l}\text { Blinding of outcome as- } \\
\text { sessment (detection bias) } \\
\text { All outcomes }\end{array}$ & Low risk & Outcome of interest (mode of delivery) objective \\
\hline $\begin{array}{l}\text { Baseline characteristics } \\
\text { similar? }\end{array}$ & Low risk & $\begin{array}{l}\text { "Socioeconomic and clinical baseline characteristics...were similar, except } \\
\text { more intervention women reported experiencing problems after their previous } \\
\text { caesarean section (infection, pain, breastfeeding problems) compared with } \\
\text { the control group" }\end{array}$ \\
\hline $\begin{array}{l}\text { Baseline outcome mea- } \\
\text { surements similar? }\end{array}$ & Low risk & Baseline outcome measures (pre-scores) comparable \\
\hline $\begin{array}{l}\text { Incomplete outcome data } \\
\text { (attrition bias) } \\
\text { All outcomes }\end{array}$ & Low risk & Proportion of missing data is similar in both groups \\
\hline $\begin{array}{l}\text { Selective reporting (re- } \\
\text { porting bias) }\end{array}$ & Low risk & No evidence of selective outcome reporting \\
\hline $\begin{array}{l}\text { Protected against contam- } \\
\text { ination? }\end{array}$ & Low risk & Decision-aid was provided only to those in the intervention arm \\
\hline Other bias & Low risk & No evidence of other bias \\
\hline
\end{tabular}

\section{Srinivas 2016}

\begin{tabular}{ll}
\hline Methods & Controlled before-after study \\
\hline Participants & USA \\
Hospitals, matched $2: 1$ non-labourist to labourist using the following variables. \\
- Annual volume of deliveries categorised as $<=1000$ or $>1000$ \\
- Geography based on USA census bureau designated areas: Northeast, Midwest, South, West \\
- Teaching hospital status (presence of obstetric residents) \\
\hline
\end{tabular}


Srinivas 2016 (Continued)

Interventions

Intervention: labourist model of obstetric care

Control: standard care provided by the regular staff attending deliveries

\section{Outcomes}

Caesarean delivery, chorioamnionitis, induction of labour, preterm birth, maternal prolonged length of stay ( $>2$ days postpartum for vaginal delivery; $>4$ days postpartum for caesarean delivery), Apgar at 5 minutes of $<7$, birth asphyxia, injury, trauma, and neonatal death

Notes

Baseline (control group) CS rate: $28.5 \%$

Date of study: 1998 to 2011

Funding: Maternal and Child Health Bureau R40

Conflict of interest: the authors declare that they have no known conflict of interests.

\section{Risk of bias}

\begin{tabular}{|c|c|c|}
\hline Bias & Authors' judgement & Support for judgement \\
\hline $\begin{array}{l}\text { Random sequence genera- } \\
\text { tion (selection bias) }\end{array}$ & High risk & Controlled before-after design \\
\hline $\begin{array}{l}\text { Allocation concealment } \\
\text { (selection bias) }\end{array}$ & High risk & Controlled before-after design \\
\hline $\begin{array}{l}\text { Blinding of participants } \\
\text { and personnel (perfor- } \\
\text { mance bias) } \\
\text { All outcomes }\end{array}$ & Low risk & Likelihood of performance bias considered minimal \\
\hline $\begin{array}{l}\text { Blinding of outcome as- } \\
\text { sessment (detection bias) } \\
\text { All outcomes }\end{array}$ & Unclear risk & Main outcome of interest (mode of delivery) objective \\
\hline $\begin{array}{l}\text { Baseline characteristics } \\
\text { similar? }\end{array}$ & Low risk & $\begin{array}{l}\text { "Hospital level characteristics were largely balanced post match with a few } \\
\text { small non-significant differences related to delivery volume and geography } \\
\text { (Table } 2 \text { in the article)" }\end{array}$ \\
\hline $\begin{array}{l}\text { Baseline outcome mea- } \\
\text { surements similar? }\end{array}$ & Low risk & Baseline outcomes between study groups comparable \\
\hline $\begin{array}{l}\text { Incomplete outcome data } \\
\text { (attrition bias) } \\
\text { All outcomes }\end{array}$ & Low risk & No evidence of attrition bias \\
\hline $\begin{array}{l}\text { Selective reporting (re- } \\
\text { porting bias) }\end{array}$ & Low risk & No evidence of selective outcome reporting \\
\hline $\begin{array}{l}\text { Protected against contam- } \\
\text { ination? }\end{array}$ & Low risk & Likelihood of contamination considered minimal \\
\hline Other bias & Low risk & No evidence of other bias \\
\hline
\end{tabular}


Valiani 2014

\begin{tabular}{ll}
\hline Methods & Randomised trial \\
\hline Participants & Iran \\
Inclusion criteria \\
- Mothers (alone) and couples (mothers and their respective partners) attending health centres in Iran \\
- Primiparous in 26-32 weeks of gestational age \\
- Spouses' literacy \\
- Having adequate physical and physiological health to actively attend the workshop \\
$*$ severe midwifery problems related to pregnancy \\
$*$ any baseline specific diseases \\
$*$ any diagnosable contraindication for CS during pregnancy \\
$*$ any psychological diseases \\
$*$ an unexpected pregnancy
\end{tabular}

Interventions

Intervention: childbirth training workshop

Control: conventional and routine education during maternal care by the midwives in healthcare centres, gynaecologists, and relatives

\begin{tabular}{ll}
\hline Outcomes & Knowledge, attitude, and delivery mode \\
\hline Notes & Baseline (control group) CS rate: $73.3 \%$ \\
& Date of study: not reported \\
& Funding: Isfahan University of Medical Sciences \\
& Conflict of interest: the authors declare that they have no known conflict of interests.
\end{tabular}

\section{Risk of bias}

\begin{tabular}{|c|c|c|}
\hline Bias & Authors' judgement & Support for judgement \\
\hline $\begin{array}{l}\text { Random sequence genera- } \\
\text { tion (selection bias) }\end{array}$ & Low risk & $\begin{array}{l}\text { "For random allocation of the subjects, the sequence of subjects' allocation to } \\
\text { either of the above mentioned groups was made by draw as mothers, couples, } \\
\text { and control." }\end{array}$ \\
\hline $\begin{array}{l}\text { Allocation concealment } \\
\text { (selection bias) }\end{array}$ & Unclear risk & Not specified in the report \\
\hline $\begin{array}{l}\text { Blinding of participants } \\
\text { and personnel (perfor- } \\
\text { mance bias) } \\
\text { All outcomes }\end{array}$ & Unclear risk & Not specified in the report \\
\hline $\begin{array}{l}\text { Blinding of outcome as- } \\
\text { sessment (detection bias) } \\
\text { All outcomes }\end{array}$ & Low risk & Main outcome of interest (mode of delivery) objective \\
\hline $\begin{array}{l}\text { Baseline characteristics } \\
\text { similar? }\end{array}$ & Low risk & No important difference were present \\
\hline $\begin{array}{l}\text { Baseline outcome mea- } \\
\text { surements similar? }\end{array}$ & Low risk & No important difference were present \\
\hline
\end{tabular}


Valiani 2014 (Continued)
Incomplete outcome data
Unclear risk
Insufficient information provided in the report
(attrition bias)

All outcomes

\begin{tabular}{lll}
\hline $\begin{array}{l}\text { Selective reporting (re- } \\
\text { porting bias) }\end{array}$ & Low risk & $\begin{array}{l}\text { All relevant outcomes in the methods section are reported in the results sec- } \\
\text { tion }\end{array}$ \\
\hline $\begin{array}{l}\text { Protected against contam- } \\
\text { ination? }\end{array}$ & Unclear risk & Allocation was by individual patients (cannot rule out contamination) \\
\hline Other bias & Low risk & No evidence of other bias \\
\hline
\end{tabular}

Wang 2014

\begin{tabular}{ll}
\hline Methods & Randomised trial \\
\hline Participants & China \\
& $\begin{array}{l}\text { Inclusion criteria: 16-32 weeks of gestation, normal cognitive function; no history of childbirth or abor- } \\
\text { tion; diagnosis of singleton pregnancy by B-ultrasound; no obvious risk factors according to prenatal } \\
\text { and B-ultrasound examination findings; and no history of urinary incontinence, pelvic surgery, pelvic } \\
\text { organ prolapse, or vaginal wall prolapse }\end{array}$ \\
\hline Interventions & $\begin{array}{l}\text { Intervention: pelvic floor muscle training exercises with telephone follow-up } \\
\text { Control: pelvic floor muscle training without telephone follow-up }\end{array}$ \\
\hline Outcomes & $\begin{array}{l}\text { Delivery mode, timing of each labour stage (first through third stages) (details of other outcomes avail- } \\
\text { able in paper) }\end{array}$ \\
\hline Botes & Baseline (control group) CS rate: $49.1 \%$ \\
& $\begin{array}{l}\text { Fate of study: December } 2010 \text { to March } 2011 \\
\text { Cunding: } 2010 \text { Youth Fund Project of Guangzhou Medical University (Project number: 2010A03) }\end{array}$
\end{tabular}

\section{Risk of bias}

\begin{tabular}{lll}
\hline Bias & Authors' judgement & Support for judgement \\
\hline $\begin{array}{l}\text { Random sequence genera- } \\
\text { tion (selection bias) }\end{array}$ & Unclear risk & No information provided in the report \\
\hline $\begin{array}{l}\text { Allocation concealment } \\
\text { (selection bias) }\end{array}$ & Unclear risk & No information provided in the report \\
\hline $\begin{array}{l}\text { Blinding of participants } \\
\text { and personnel (perfor- } \\
\text { mance bias) }\end{array}$ & Unclear risk & No information provided in the report \\
$\begin{array}{l}\text { All outcomes } \\
\text { Blinding of outcome as- } \\
\text { sessment (detection bias) } \\
\text { All outcomes }\end{array}$ & Low risk & Main outcome of interest (mode of delivery) objective \\
\hline
\end{tabular}


Wang 2014 (Continued)

\begin{tabular}{lll}
$\begin{array}{l}\text { Baseline characteristics } \\
\text { similar? }\end{array}$ & Low risk & No important difference present \\
\hline $\begin{array}{l}\text { Baseline outcome mea- } \\
\text { surements similar? }\end{array}$ & Low risk & No important difference present
\end{tabular}

surements similar?

Incomplete outcome data Unclear risk Insufficient information provided in the report
(attrition bias)

All outcomes

\begin{tabular}{lll}
\hline $\begin{array}{l}\text { Selective reporting (re- } \\
\text { porting bias) }\end{array}$ & Low risk & $\begin{array}{l}\text { All relevant outcomes in the methods section are reported in the results sec- } \\
\text { tion }\end{array}$ \\
\hline $\begin{array}{l}\text { Protected against contam- } \\
\text { ination? }\end{array}$ & Low risk & $\begin{array}{l}\text { Allocation was by practice and it is unlikely that the control group received the } \\
\text { intervention }\end{array}$ \\
\hline Other bias & Low risk & No evidence of other bias \\
\hline
\end{tabular}

CS: caesarean section; VBAC: vaginal birth after caesarian

Characteristics of excluded studies [ordered by study ID]

\begin{tabular}{|c|c|}
\hline Study & Reason for exclusion \\
\hline Afshar 2015 & Ineligible design (prospective cohort study) \\
\hline Arrieta 2011 & Intervention not aimed at reducing caesarean birth \\
\hline Bailey 2010 & Intervention not aimed at reducing caesarean birth \\
\hline Barber 2010 & Intervention not aimed at reducing caesarean birth \\
\hline Bernitz 2011 & Intervention assessed addressed in a related Cochrane Review (Sandall 2016) \\
\hline Bonfrer 2016 & $\begin{array}{l}\text { National Health Insurance Scheme designed to increase access to maternal and infant healthcare } \\
\text { services (including caesarean sections) }\end{array}$ \\
\hline Calvo 2009 & Uncontrolled before-after study \\
\hline Chambliss 1992 & Intervention assessed addressed in a related Cochrane Review (Sandall 2016) \\
\hline Chen 2014 & Uncontrolled before-after study \\
\hline Chittithavorn 2006 & ITS study with insufficient data points (only one data point before and after intervention) \\
\hline Costa 2009 & Uncontrolled before-after study \\
\hline David 2001 & Not an intervention study \\
\hline Dunn 2013 & Uncontrolled before-after study \\
\hline Fournier 2014 & Study assessed effect of fee exemption intended to increase access to caesarean deliveries \\
\hline Ganji 2006 & Uncontrolled before-after study \\
\hline
\end{tabular}




\begin{tabular}{|c|c|}
\hline Study & Reason for exclusion \\
\hline Gilbert 2012 & No control group \\
\hline Gregory 1999 & ITS study with insufficient data points (fewer than 3 data points before intervention) \\
\hline Gruber 1999 & The study was not an intervention study \\
\hline Hemminki 2013 & Interventions in study were not specifically aimed at reducing caesarean section rate \\
\hline Ho 2011 & Uncontrolled before-after study \\
\hline Howell 2004 & ITS study with insufficient data points (fewer than 3 data points before intervention) \\
\hline Hutcheon 2015 & $\begin{array}{l}\text { Not specifically designed to assess effect on primary outcome measures (primary outcome was a } \\
\text { composite of adverse neonatal outcomes) }\end{array}$ \\
\hline Iglesias 1991 & ITS study with insufficient data points (fewer than 3 data points before intervention) \\
\hline Jenabi 2012 & Does not measure primary outcome of interest \\
\hline Jiang 2015 & Major methodological flaws \\
\hline Kasawara 2013 & Interventions in study were not aimed at reducing caesarean section rate \\
\hline Kazandjian 1998 & Retrospective cohort, observation study \\
\hline Kim 2005 & ITS study with insufficient data points ( 2 data points after the intervention) \\
\hline Kiwankura 1993 & ITS study with insufficient data points (only 1 data point before and after intervention) \\
\hline Kongnyuy 2008 & ITS study with insufficient data points \\
\hline Koroukian 2001 & Not an intervention study \\
\hline Kunthonkitidej 2001 & Insufficient number of sites to determine trend \\
\hline Lagrew 1996 & ITS study with insufficient data points (fewer than 3 data points before intervention) \\
\hline Law 1999 & Intervention assessed addressed in a related Cochrane Review (Sandall 2016) \\
\hline Lee 2007 & Controlled ITS with insufficient data points after the intervention to determine trend \\
\hline Leone 2016 & $\begin{array}{l}\text { Study evaluates impact of user fee reform intended to increase access to maternal and child health } \\
\text { services (including caesarean sections) }\end{array}$ \\
\hline Main 1999 & CBA (data compared were not the same time and inappropriate control group) \\
\hline Misra 2008 & ITS study with insufficient data points before and after the intervention \\
\hline Morhason-Bello 2009 & Intervention addressed in a related Cochrane Review (Bohren 2017) \\
\hline Myers 1993 & ITS study with insufficient data points (only 1 data point before intervention) \\
\hline Oleske 1992 & ITS study with insufficient data points (fewer than 3 data points before intervention) \\
\hline Robson 1996 & ITS study with insufficient data points (fewer than 3 data points before intervention) \\
\hline
\end{tabular}




\begin{tabular}{|c|c|}
\hline Study & Reason for exclusion \\
\hline Saint 2003 & Caesarean section rate not measured \\
\hline Sanavi 2014 & $\begin{array}{l}\text { The study does not measure mode of delivery (reports behavioural intention change in women in- } \\
\text { tending to have a caesarean section) }\end{array}$ \\
\hline Santerre 1996 & Not an intervention study \\
\hline Socol 1993 & ITS study with no defined intervention time point \\
\hline Tussey 2015 & Clinical intervention \\
\hline van Dillen 2008 & Uncontrolled before-after study \\
\hline Walker 2016 & Intervention not specifically designed to reduce caesarean section rate \\
\hline Werner 2013 & Intervention not aimed at reducing caesarean section rate \\
\hline Zanetta 1999 & ITS study with insufficient data points (only 1 data point before intervention) \\
\hline Zhang 2016 & Intervention addressed in a related Cochrane Review (Sandall 2016) \\
\hline
\end{tabular}

CBA: controlled before-after; ITS: interrupted time series

Characteristics of studies awaiting assessment [ordered by study ID]

\begin{tabular}{ll} 
Jang 2011 & Interrupted time series study \\
\hline Methods & $\begin{array}{l}\text { Setting: South Korea } \\
\text { Time-series autoregressive integrated moving average (ARIMA) analysis was used to assess the ef- } \\
\text { fect of four repeated public releases (RPR) on caesarean section rates }\end{array}$ \\
\hline Participants & $\begin{array}{l}\text { Data sources: monthly data about institutional caesarean section rates and total deliveries from } \\
\text { the Health Insurance Review \& Assessment Service (HIRA) National Quality Improvement project } \\
\text { database from } 2003 \text { through } 2007\end{array}$ \\
\hline Interventions & Repeated public releases on caesarean section rates \\
\hline Outcomes & Caesarean section rates \\
\hline Notes & Study will be considered for inclusion in the next update of the review
\end{tabular}

Vankan 2015

Methods
"Women pregnant after one previous CS without a contra-indication for an intended VB were en-
rolled in six matched pairs of hospitals."
"The vaginal birth (VB) rate in the period before the study started was $48 \%$. A difference of $>10 \%$
was considered 'inferior' care. The sample size needed was 400 per study arm"


Vankan 2015 (Continued)

Participants

Women pregnant after one previous caesarean section without a contraindication for an intended vaginal birth

Interventions

Intervention ( $\mathrm{n}=479$ women)

Women in the intervention hospitals received a decision analysis, including both information on benefits and risks of intended vaginal birth or elective repeat caesarean delivery and a prediction model to calculate the individual vaginal birth probability

Control ( $n=441$ women)

Counselling in the control hospitals was performed according to usual care

Outcomes Patient involvement, vaginal birth rate, elective and emergency caesarean section rate

Notes Study will be considered for inclusion in the next update of the review

\section{Characteristics of ongoing studies [ordered by study ID]}

\section{ACTRN12611000878976}

Trial name or title

For pregnant women in the first half of their pregnancy with history of previous caesarean and eligible for vaginal birth after caesarean (VBAC), will using a decision aid increase their rate of VBAC compared to using a pamphlet?

\section{Country: New Zealand}

Study design: randomised trial

\begin{tabular}{|c|c|}
\hline Participants & History of one previous caesarean less than 25 weeks gestation in current pregnancy \\
\hline \multirow[t]{2}{*}{ Interventions } & $\begin{array}{l}\text { Intervention: the decision aid is a comprehensive } 25 \text { page booklet that first explains the risks and } \\
\text { benefits of elective repeat caesarean and of VBAC, and then asks the woman to write down her own } \\
\text { values and preferences about the two birth options. It will be administered at the time of the con- } \\
\text { sultation in the Positive Birth After Caesarean Clinic. }\end{array}$ \\
\hline & $\begin{array}{l}\text { Control: the patient pamphlet is } 6 \text { pages and briefly lists risks and benefits of elective repeat cae- } \\
\text { sarean and of VBAC. It is administered at the time of the consultation in Positive Birth After Cae- } \\
\text { sarean Clinic }\end{array}$ \\
\hline \multirow[t]{4}{*}{ Outcomes } & Primary outcome: the rate of VBAC is determined using the perinatal database at the hospital \\
\hline & Secondary outcomes \\
\hline & - Mean decisional conflict score about birth choice \\
\hline & - Mean knowledge score about birth choices \\
\hline Starting date & September 2014 \\
\hline Contact information & Michelle Wise: m.wise@auckland.ac.nz \\
\hline Notes & Trial registry number: ACTRN12611000878976 \\
\hline
\end{tabular}


ACTRN12611001214921

Trial name or title A randomised controlled trial
Does continuity of care impact decision making in the next birth after a caesarean section (VBAC)?

\begin{tabular}{ll}
\hline Methods & Randomised trial \\
\hline Participants & Pregnant women whose most recent birth was by caesarean section \\
\hline Interventions & Midwifery continuity of care to women through pregnancy, labour, birth and early postnatal care \\
& $\begin{array}{l}\text { Control: standard hospital care from different midwives through pregnancy, labour, birth and early } \\
\text { postnatal care }\end{array}$
\end{tabular}

\section{Outcomes}

Primary outcome: proportion of women who attempt vaginal birth in their current pregnancy

Secondary outcomes: proportion of vaginal births; neonatal health assessed at birth and at 28 days (Apgar scores, admission to special care nursery, length of stay in hospital, readmission to hospital); women's social and emotional outcomes examined using a survey at 36 weeks of pregnancy and at 6 weeks postpartum

\begin{tabular}{ll}
\hline Starting date & Not yet recruiting (anticipated 30/06/2012; as per trial registry record) \\
\hline Contact information & caroline.homer@uts.edu.au \\
\hline Notes & Trial registry number: ACTRN12611001214921; DOI: 10.1186/1471-2393-13-140 \\
\hline
\end{tabular}

\section{ACTRN12613000161729}

Trial name or title $\quad$ Enhanced care and support in early labour (ECSEL): a randomised controlled trial to reduce cae-
sarean sections for first-time mothers

\begin{tabular}{ll}
\hline Methods & Country: Australia \\
& Study design: randomised trial \\
\hline Participants & $\begin{array}{l}\text { Inclusion criteria: women at normal risk of complication having their first baby booked at a partic- } \\
\text { ipating hospital; live within } 30 \text { minutes drive of the hospital; English-speaking }\end{array}$ \\
& $\begin{array}{l}\text { Exclusion criteria: complications of pregnancy that would indicate early admission to hospital in } \\
\text { labour (e.g. foetal growth restriction, antepartum haemorrhage, planned caesarean section) }\end{array}$ \\
\hline
\end{tabular}

Interventions

Intervention: standard care in early labour is to telephone the midwife in the hospital birthsuite and seek advice on whether or not to come to hospital. The intervention here is that a known midwife will provide enhanced support (via telephone and/or home visiting) to assist women in the early or latent phases of labour to remain at home until labour is well established unless there is a reason to be admitted earlier. The support will include listening to the woman, taking a detailed history, assessing her current stage of labour and coping ability, advising whether or not to come to hospital, suggesting pain relief strategies and providing reassurance. This will be the midwife's main role, whereas midwives usually providing such guidance are concurrently providing care to women already admitted to hospital in labour. The study midwife will also visit the woman at home if this would be helpful (to be decided on an individual basis by the woman and the midwife). The duration of this additional support will vary according to individual needs between around 15 minutes and 3 hours.

Control: women telephone midwives working in birthsuite/emergency department when they want advice readmission to hospital for the birth (standard care)

Outcomes $\quad$ Primary outcome: caesarean section for any indication




\section{Secondary outcomes}

- Instrumental vaginal birth

- Length of time from hospital admission to birth

- Admission to hospital with cervical

- Use of oxytocin infusion to induce or augment labour

- Cost of maternity care

- Use of epidural analgesia for relief of pain in labour

- Postpartum haemorrhage

- Apgar score < 7 (5 minutes after birth)

- Maternal satisfaction with intrapartum care

- Breastfeeding

- Neonatal admission to special care or neonatal intensive care

- Maternal admission to high-dependency care

- Neonatal resuscitation more intensive than oxygen and/or suction

- Score $>12$ on Edinburgh Postnatal Depression

\begin{tabular}{ll}
\hline Starting date & Anticipated: September 2014 \\
\hline Contact information & Mary-Ann Davey: m.davey@latrobe.edu.au \\
\hline Notes & Trial registry number: ACTRN12613000161729 \\
\hline
\end{tabular}

\section{IRCT2013111010777N3}

Trial name or title care
The impact of a computerised decision aid on the mode of delivery, compared with conventional

Country: Iran

Study design: randomised, parallel group trial

Participants

Inclusion criteria: positive pregnancy test, being in good health, pregnancy above 28 weeks, and singleton pregnancy

Exclusion criteria: unwanted pregnancy, inability to read and write and working with computer, experience of previous caesarean section

Interventions Intervention group: they will receive a computer-based decision aid on mode of delivery

Control group: they will receive the conventional care

\section{Outcomes}

Primary outcome: decisional conflict, knowledge

Secondary outcome: mode of delivery

\begin{tabular}{ll}
\hline Starting date & December 2013 \\
\hline Contact information & Saeid Eslami: eslams@mums.ac.ir \\
\hline Notes & IRCT registration number: IRCT2013111010777N3 \\
\hline
\end{tabular}




\section{ISRCTN10612254}

Trial name or title Improving the organisation of maternal health service delivery, and optimising childbirth, by in creasing vaginal birth after caesarean section (VBAC) through enhanced women-centred care

\section{Methods}

$$
\text { Countries: Germany, Ireland and Italy }
$$

Study design: multicentre cluster-randomised trial

Participants
- Pregnant women aged over 18 years
- Pregnant women who have had one previous caesarean section
- Pregnant women who speak a language for which translation is available

Interventions

Intervention: evidence-based education of women and clinicians, introduction of communities of practice (women and clinicians sharing knowledge), opinion leaders, audit and peer review of caesarean sections in each hospital, and joint decision-making by women and clinicians. The content and details of the intervention will be determined through systematic reviews and qualitative research

Control: usual care

Primary outcomes: change from baseline in each hospital in the proportion of women who have
had one previous caesarean section who have a vaginal birth during the study
Secondary outcomes
- Gestational age at birth
- Length of labour
- Emotional well-being, feelings of anxiety, control, satisfaction with care and perception of in-
volvement in care, during pregnancy and the postnatal period
- Intrapartum interventions (induction or augmentation of labour, use of epidural and foetal mon-
- Maternal morbidities during pregnancy and the postnatal period (for example, pain, postpartum
- haemorrhage, wound infection, abdominal pain, depression)
- Beonatal morbidities (resuscitation, Apgar scores, admission to intensive care)
- Length of hospital stay (mother and infant).
- Readmission

Health economic analyses will be done using data on clinical outcomes, direct costs (such as length of stay and antibiotic use) and indirect costs (such as productivity loss) during pregnancy and postnatal period. The study will also seek to assess adherence to guidelines and practice protocols, adherence to intervention quantity and quality, and midwife-centred variables; to compare and contrast findings across the different hospitals.

\begin{tabular}{ll}
\hline Starting date & December 2013 \\
\hline Contact information & Cecily Begley: cbegley@tcd.ie \\
\hline Notes & Trial registry number: SRCTN10612254; DOI: 10.1186/ISRCTN10612254 \\
\hline
\end{tabular}

Trial name or title Appropriate decision for caesarean section in Burkina Faso


ISRCTN48510263 (Continued)

Methods

\author{
Country: Burkina Faso
}

Study design: cluster-randomised trial

\section{Participants}

\section{Participant inclusion criteria}

For the hospitals:

- A minimum of 1000 deliveries per year

- A minimum of 200 caesarean sections per year

- The permanent availability of emergency caesarean section

- The absence of current or recent experience in clinical audits for caesarean

- Willingness to participate in the study is materialised by a written and signed ward agreement by the hospital director and the head of the maternity unit

- District or regional hospital

For the patients: all women who deliver by caesarean section in selected hospitals during the study period

For the health professionals: all health professionals involved in the decision-making process for a caesarean section: obstetricians, general practitioners, nurses and midwives

\section{Interventions}

The evidence-based intervention will consist of three strategies to improve the competencies of maternity teams

- Clinical audits based on objective criteria

- Training of personnel

- Decision-support reminders of indications for caesareans via text messages

To analyse the intervention process, a longitudinal qualitative study consisting of deliberative workshops and individual in-depth interviews will be conducted.

Control group: no external intervention is planned for this group

Outcomes Primary outcomes

Change in the rate of non-medically justified caesarean sections among all caesarean sections

\section{Secondary outcomes}

- Knowledge score of health care professionals using specific vignettes

- Quality scores for the practice of caesareans based on objective criteria (specific tasks)

- Score of resource availability using the complexity index proposed by WHO

- Fatality rate of caesarean sections (mother and child)

\begin{tabular}{ll}
\hline Starting date & March 2014 \\
\hline Contact information & Charles Kabore: kaborewendyam@yahoo.fr \\
\hline Notes & Trial registry number: ISRCTN48510263; DOI 10.1186/ISRCTN48510263 \\
& Protocol: http://www.ncbi.nlm.nih.gov/pubmed/27769190
\end{tabular}




\section{ISRCTN50041378}

Trial name or title Reducing caesarean section rates in Ireland: a feasibility study and pilot randomised trial of an evidence-based intervention designed to reduce unnecessary caesarean section

\section{Methods}

\section{Country: Ireland}

Study design: feasibility study and pilot cluster randomised trial

Setting: hospitals

Target number of participants: 2 clusters ( 400 participants in each cluster)

Participants
- Pregnant woman
- Aged over 18
- Speak either English or a language for which translation is available
- Give informed consent
Participant exclusion criteria
- Vaginal birth contraindicated at time of booking
Intervention
Intervention will likely consist of an appointment of an obstetric and midwife opinion leader who
will facilitate women-centred, evidence-based antenatal classes (2 classes) and information ses-
sion for clinicians, providing accurate information on the risks and benefits of both VBAC and re-
peat caesarean sections, second opinions for all caesarean sections (other than category 1 ), peer-
review of each caesarean section and feedback, reducing induction of labour rates, support of clini-
cians and women to choose normal options over medical intervention (e.g. mobility instead of oxy-
tocin, water-bath instead of pharmacological pain relief, reducing use of electronic foetal monitor-
ing in low-risk women)

\section{Control}

Usual care as per current hospital practice

\section{Outcomes}

\section{Primary outcome measures}

- Caesarean section rate (overall per site)

\section{Secondary outcome measures}

- Labour interventions (e.g. induction and acceleration of labour, pain relief used, electronic foetal monitoring)

- Maternal/neonatal morbidities (e.g. postpartum haemorrhage, perineal trauma, wound infection, need for neonatal resuscitation, neonatal admission to intensive care, readmission to hospital)

- Mother and baby health problems assessed using self-completion surveys (health and well-being questionnaires that include the SF-36 instrument) during pregnancy and at 3 and 6 months postnatal

- Clinician attitudes to caesarean section measured by a self-completion questionnaire adapted from the UK National Sentinel Caesarean Section Audit

- Feasibility and pilot outcomes (\% eligible and participating, time to recruit, etc.) assessed using trial screening and eligibility forms, numbers participating (consent forms) and time to recruit full sample size

\begin{tabular}{ll}
\hline Starting date & September 2017 \\
\hline Contact information & Cecily Begley: cbegley@tcd.ie
\end{tabular}


ISRCTN50041378 (Continued)

\begin{tabular}{|c|c|}
\hline Trial name or title & The REDUCED Trial: REDucing the Utilization of CEsarean Sections for Dystocia (REDUCED) \\
\hline \multirow[t]{2}{*}{ Methods } & Country: Canada \\
\hline & Study design: cluster-randomised trial \\
\hline Participants & $\begin{array}{l}\text { Inclusion criteria: centres in Alberta that provide intrapartum care, have facilities to perform cae- } \\
\text { sarean section and deliver at least } 70 \text { primiparous women annually }\end{array}$ \\
\hline \multirow[t]{2}{*}{ Interventions } & $\begin{array}{l}\text { Intervention: application of a knowledge translation strategy, of new clinical practice guidelines } \\
\text { on labour management, to physicians and nurses caring for women in labour }\end{array}$ \\
\hline & Control: no intervention \\
\hline \multirow[t]{7}{*}{ Outcomes } & Primary outcome: rate of caesarean section in primiparous women in labour \\
\hline & Secondary outcomes \\
\hline & - Perinatal death \\
\hline & $\begin{array}{l}\text { - NICU admission with arterial blood gasses } \mathrm{pH}<7 \text { and base excess }>=12 \text { or NICU admission with } \\
\text { Apgar at } 5 \text { minutes }<7\end{array}$ \\
\hline & - Moderate or severe asphyxia or meets criteria for therapeutic cooling \\
\hline & - Neonatal sepsis or suspected sepsis \\
\hline & - Postpartum haemorrhage/blood transfusion \\
\hline
\end{tabular}

\begin{tabular}{ll}
\hline Starting date & October 2016 \\
\hline Contact information & Stephen Wood: slwood@ucalgary.ca \\
\hline Notes & NCT Number: NCT02874443
\end{tabular}

NICU: Neonatal intensive care unit; VBAC: vaginal birth after caesarean

\section{ADDITIONAL TABLES}

Table 1. Classification of non-clinical interventions

Intervention Examples of interventions

\section{Interventions targeted at women, the community, or the general public}

- Non-clinical educational interventions (e.g. educational games, materials, meetings)

- Different modes or formats of communication (e.g. information and communica-
- Booklets on vaginal birth after caesarean (VBAC)

- Educational sessions on VBAC

- Computer decision aids on VBAC

- Special childbirth classes to explain active management of labour (AML) protocol

- Birth preparation classes

- Antenatal classes to reduce anxiety in nulliparous women

- Special classes for women with fear of birth 
Table 1. Classification of non-clinical interventions (Continued)

tion technology, written, ra-

dio, television)

- Opinion leaders

Dissemination of information or advocacy with support or campaigns from local or international opinion leaders

- Role models

- Leadership persons

- Public celebrities

- Public dissemination of CS - Informing the public about CS rates by releasing performance data in written or electronic form rates

\section{Interventions targeted at healthcare professionals}

- Educational interventions targeted at healthcare professionals aiming to improve adherence to evidence-based clinical practice
- Education of nurses to focus on childbirth in group sessions during antenatal care (ANC) (this is a type of 'training the teacher': educational intervention)

- Mailed educational material on trial of labour after caesarean (TOLAC) for physicians

- Education of staff on management of labour using evidence-based practice guidelines

- Education of nurses, physicians and community about labour support

- Community education strategy (presentations on VBAC, foetal distress, breech and other common indications for (S) for healthcare professionals and lay people

- Workshops for physicians on strategies to reduce CS, with calls in-between to share experiences

- Policy of second opinion for - Requirement of second opinion by an obstetrician on caesarean decisions CS indication

- Audit and feedback and peer review
- Summary of health workers' performance over a specified period of time, given to them in a written electronic or verbal format. Summary may include recommendations for clinical action

\section{Interventions targeted at healthcare organisations or facilities}

- Staffing models

Different types of nurse/midwife staffing models

- Midwife-led delivery units

Different types of physician staffing models

- 24-hour in-house physician

- Changing the physical or sensory environment of labour and delivery
- Changes to the physical or sensory healthcare environment, by adding or altering equipment or layout, providing music, art

- Pay for performance (target payments)

- Incentives for career

- Equalise the payment for CS and VD or higher payment for VD than CS

- Payment for 24-hour shifts, not for number of procedures

- Financial penalties for exceeding certain CS rate

- Additional payment if CS rate during shifts is maintained below a predefined threshold

- Episode-based payment

- Blended case rate payment

\section{- Goal-setting for CS rates}

- Policies that limit financial/legal liability in case of
- Setting specific predetermined goal for CS rate

- Policies limiting financial/legal liability in case of litigation 
Table 1. Classification of non-clinical interventions (Continued)

litigation of healthcare pro-

fessionals or organisations

- Strategies to change the organisational culture
- Strategies include various components of organisational culture (e.g. shared values, behaviours, norms, traditions, sense-making) which may shape, or contribute, or both, to the overall environment of an organisation

AML: active management of labour; ANC: antenatal care; CS: caesarean section; VBAC: vaginal birth after caesarean; VD: vaginal delivery; TOLAC: trial of labour after caesarean

Table 2. Examples of determinants of caesarean section births and interventions targeted at the determinants

\begin{tabular}{|c|c|c|}
\hline Level & Determinants & Interventions \\
\hline \multirow[t]{2}{*}{$\begin{array}{l}\text { Healthcare recipients } \\
\text { (women, families) }\end{array}$} & $\begin{array}{l}\text { - Fear of childbirth } \\
\text { - Anxiety about childbirth }\end{array}$ & $\begin{array}{l}\text { - Birth preparation classes } \\
\text { - Special classes for women with fear of childbirth } \\
\text { - Psychoeducation }\end{array}$ \\
\hline & $\begin{array}{l}\text { - Lack of awareness of the potential } \\
\text { harms of CS }\end{array}$ & $\begin{array}{l}\text { - Antenatal education } \\
\text { - Educational brochures } \\
\text { - Decision aids }\end{array}$ \\
\hline \multirow[t]{2}{*}{$\begin{array}{l}\text { Healthcare profession- } \\
\text { als }\end{array}$} & $\begin{array}{l}\text { Non-adherence to evidence-based } \\
\text { clinical practice guidelines }\end{array}$ & $\begin{array}{l}\text { - Targeted in-service training } \\
\text { - Academic detailing } \\
\text { - Mandatory second opinion on CS decisions } \\
\text { - Local opinion leaders }\end{array}$ \\
\hline & $\begin{array}{l}\text { - Physicians unaware of individual } \\
\text { CS practices }\end{array}$ & - Audit and feedback \\
\hline \multirow[t]{3}{*}{$\begin{array}{l}\text { Healthcare organisa- } \\
\text { tions or facilities }\end{array}$} & - Staffing models & $\begin{array}{l}\text { - Midwife-led delivery care } \\
\text { - Laborist model of obstetric care }\end{array}$ \\
\hline & $\begin{array}{l}\text { - Payment methods for healthcare } \\
\text { workers }\end{array}$ & $\begin{array}{l}\text { - Equalising payment for CS and VD or higher payment for VD } \\
\text { - Payment for } 24 \text {-hour shifts (not for number of procedures) }\end{array}$ \\
\hline & $\begin{array}{l}\text { - Lack of awareness of facility CS } \\
\text { practices }\end{array}$ & - Public dissemination of facility CS rates \\
\hline
\end{tabular}

CS: caesarean section; VD: vaginal delivery

Table 3. Primary and secondary outcome measures

\author{
Maternal mortality and morbidity \\ 1. Maternal death \\ 2. Maternal morbidity \\ Perineal or vaginal trauma \\ - 2 2nd, 3rd, or 4th degree perineal tears \\ - Obstetric anal sphincter injury \\ - Vaginal tears \\ - Episiotomy
}


Table 3. Primary and secondary outcome measures

- Perineal suturing

- Postpartum perineal pain

Maternal morbidity

- Febrile morbidity

- Peripartum infection

- Wound complication

- Postpartum haemorrhage

Serious maternal morbidity

- Severe obstetric haemorrhage

- Uterine rupture

- Sepsis

- Obstetric hysterectomy

- Organ failure

Long-term maternal outcomes

- Urinary or faecal incontinence

- Obstetric fistula

- Utero-vaginal prolapse

\section{Neonatal mortality and morbidity}

1. Neonatal death

2. Neonatal morbidity

Birth trauma

- Fractured skull, haematoma, cerebral haemorrhage

- Fractured clavicle, facial paralysis, brachial plexus injury

- Scalp injury, facial skin lesions

- Retinal haemorrhage

Perinatal asphyxia

- Low Apgar score (less than 7) at five minutes

- Cord blood acidosis

- Need for major resuscitation (respiratory support, intubation at birth)

- Hypoxic ischaemic encephalopathy

Long-term infant outcomes

- Breastfeeding

- Childhood disability

- Mother-infant bonding or separation

Table 4. Interventions targeted at women or families

\begin{tabular}{lll}
\hline Study & Intervention & Details \\
\hline Bastani 2006 & $\begin{array}{ll}\text { Nurse-led applied re- } \\
\text { laxation training pro- } \\
\text { gramme }\end{array}$ & $\begin{array}{l}\text { Applied relaxation education based on Ost's description of applied relax- } \\
\text { ation, including progressive muscle relaxation and breathing (see Öst 1988 } \\
\text { for details). }\end{array}$ \\
\end{tabular}


Table 4. Interventions targeted at women or families (Continued)

- Seven 90-minute group education sessions over seven weeks led by a nurse, under the supervision of a clinical psychologist - session 1: introductory group discussion of anxiety and stress-related issues in pregnancy and purpose of applied relaxation; session 2: teaching subjects to relax with a shortened version of progressive relaxation; session 3: includes 'release-only' relaxation; session 4: deep breathing techniques; session 5: 'cue-controlled' relaxation; session 6: 'differential relaxation'; session 7: 'rapid relaxation'.

- Participants are advised to practise the applied relaxation regularly and keep daily home relaxation practice records during the study

Bergstrom 2009
Antenatal education on natural childbirth preparation with training in breathing and relaxation techniques
- Education model included four, two-hour sessions during pregnancy and one follow-up session within 10 weeks after delivery. Classes started in the third trimester with groups of 12 people (6 couples).

- Focus was on preparation for natural childbirth. Information was given about non-pharmacological methods for pain relief and the partner's role as a coach during labour. In each session, 30 minutes were spent on practical training in breathing, relaxation and massage techniques. Psychoprophylactic training between sessions was encouraged and a booklet to facilitate homework was distributed. The attitude of the educator was encouraged to be in favour of natural birth. Information about breastfeeding was provided but no other postnatal issues were addressed. If possible, one of the sessions could include a visit to the delivery ward.

- The sessions were led by one midwife.

\section{Eden 2014}

Computerised decision aid versus educational brochures

\section{Computerised decision aid}

- The decision aid was designed for women with low literacy and used multiple media (text, graphics, voice-over narration for all text). The reading level was sixth to eighth grade, depending on the screen. This decision aid provided brief summaries of the medical evidence for the two options in plain language.

- The decision aid intervention also provided an explicit values clarification activity so that the women could set priorities around avoiding risk to herself, her baby, and to future pregnancies while also considering cost and her desired birth and recovery experience. Value clarification helps the women combine beliefs with their own values and helps them recognise they may have competing values.

\section{Educational brochures}

- The most current ACOG brochures on VBAC published in August 1999 and caesarean birth published in January 2005. The women could choose from the English or Spanish versions. The evidence-based brochures were developed by the Committee on Patient Education of ACOG.

- The VBAC brochure provided a description of the delivery, vaginal delivery rate range, benefits and reasons for a VBAC, explanation of type of caesarean incision, and potential risks to mother and infant. Similarly, the caesarean brochure described the delivery and recovery, benefits and reasons for a repeat caesarean, and potential risks of caesarean to the mother.

Feinberg 2015
Psychosocial couple-based prevention programme
- The psychosocial programme consisted of nine classes, with four weekly classes conducted during the second or third trimester of pregnancy and four weekly classes conducted within the first six months postpartum.

- Classes focused on emotional self-management, conflict management, problem solving, communication and mutual support strategies that foster positive joint parenting of an infant.

- A male-female facilitator team led each class; the female was a childbirth educator in all cases, and males came from various backgrounds but were experienced working with families and leading groups. 


\section{Table 4. Interventions targeted at women or families (Continued)}

Fenwick 2015
Psychoeducation by telephone
- Two sessions of psychoeducation provided at 24 and 34 weeks' gestation by telephone at a scheduled time convenient to participants. The sessions were around one hour duration (first session range: 22 to 125 minutes; second session range: 10 to 104 minutes).

- The midwife-led counselling intervention aims to support the expression of feelings and provide a framework for women to identify and work through distressing elements of childbirth.

- The intervention develops women's individual situational supports for the present and near future, affirming that negative events during childbirth can be managed, and developing a simple plan for achieving this. This combination of strategies diminishes emotional distress, builds constructive coping mechanisms and facilitates recovery.
Fraser 1997
Individualised prenatal education and support programme versus written information in pamphlet

\section{Prenatal education and support programme}

- Prenatal education and support programme provided by two individuals: a research nurse with experience in prenatal instruction and a resource person selected on the basis of communication skills and personal experience of a vaginal birth after caesarean section.

- Two individualised contacts: the research nurse on the day of randomisation and four to six weeks later by the research nurse and resource person.

First contact, duration (minutes $\pm \mathrm{SD}$ ): stratum 1 (low motivation), $57 \pm 20$; stratum 2 (high motivation): $54 \pm 20$;

second contact, duration (minutes \pm SD): stratum 1: $54 \pm 22$, stratum 2: $54 \pm 20$.

\section{Pamphlet group}

- Women in the written information group received information on the benefits of vaginal birth over elective repeat caesarean section.

Masoumi 2016
Antenatal education programme for physiologic childbirth (birth preparation training)
- Training preparation for childbirth was formed in eight sessions of two hours. These classes were held every two weeks from 20 to 34 weeks of pregnancy in the study hospital.

- The content of these classes included the mother's physical and mental changes, common problems and complications of pregnancy and ways to solve them, warning signs in pregnancy, nutrition and exercise during pregnancy and lactation, education about labour and the delivery process, and ways of coping with them, non-pharmacological methods for pain relief and the partner's role as a coach during labour.

- 10 to 15 people were in one group. In each session, 40 minutes were spent on practical training in breathing, relaxation, massage techniques and special exercise.
Montgomery 2007

\section{Computer decision aids} versus usual care
Two computer-based interventions delivered using a laptop computer, usually in the women's own home.

- Information programme and website providing information and descriptions on outcomes for mother and baby associated with planned vaginal delivery, planned caesarean section and emergency caesarean section. Probabilities of having or not having the event are given and presented in numerical and pictorial format.

- Decision analysis comprising of four steps: draw-up a decision tree that maps the likely outcomes of the strategies in question. Outcomes are assigned utilities that represent how an individual values a particular outcome. Probability information is included in the tree to represent the chance of each outcome occurring. Strategies are compared by calculating the weighted sum of the utilities of all possible outcomes. Recommended strategy is that with 
Table 4. Interventions targeted at women or families (Continued)

the highest expected utility value (the one that gives an individual the best chance of achieving an outcome that is valued).

Usual care: this comprised the usual level of care given by the obstetric and midwifery team. Women in the two intervention groups also received usual care.

$\begin{array}{ll}\text { Navaee } 2015 & \text { Role play education } \\ \text { versus standard educa- } & \text { tion using lectures }\end{array}$

\section{Role-playing group}

- The role-playing group was divided into two subgroups of 10 subjects each and another two subgroups of nine subjects each (38 subjects). Each group was instructed in a 90-minute session about the advantages and disadvantages of normal delivery and CS.

- In the warm-up stage, the researcher narrated two true stories about the individuals who were wondering about the selection of the mode of delivery due to fear of childbirth and asked the participants to voluntarily accept to play the role of pregnant woman with the researcher and two coresearchers. Then the participants helped the researcher to prepare and process the scene (scene preparation was conducted with the needed equipment for role play in two scenarios), and the observers were asked to pay close attention to the scenarios, taking important notes, and discussing them at the end of the scenario. In the scenarios, the reasons for mothers' fear of natural delivery and CS were discussed. In the first scenario, one of the participants (a pregnant woman) played the role of a woman who was referred to a midwife's office to select the mode of delivery and witnessed the events occurring in the office. Then, she was referred to the midwife and consulted with her about her concerns.

- The second scenario was about a woman with a normal delivery and the benefits and complications experienced by her. The next step was similar to the first scenario.

- In the third scenario, one of the co-researchers defended CS and another defended normal delivery. After these three scenarios, participants were asked to talk about their friends'/relatives' experiences of the two types of delivery.

\section{Standard education (lecture group)}

- Two subgroups of 10 subjects each and two subgroups of 9 subjects each was instructed using a PowerPoint presentation, marker, and whiteboard in a 90minute session. At the end of the session, participants' questions were answered.
- The psychoeducative group therapy was led by four different psychologists with special group therapeutic skills in pregnancy-related issues. Each group consisted of a maximum of six nulliparous women. Each group was led by the same psychologist from the beginning to the end. The starting point of group therapy was planned to be at approximately the 26th week of pregnancy. Six group sessions were held during pregnancy and one session with the newborns six to eight weeks after delivery.

- Each two-hour session had a certain structure: a focused topic and a 30minute guided relaxation exercise using a compact audio disk developed for this purpose. This relaxation exercise guided the participants through stages of imaginary delivery in a relaxed state of mind with positive, calming and supportive suggestions.

- The topics covered included: information about fear and anxiety, group therapy and effects of relaxation; information about fear of childbirth, normalisation of individual reactions and information about stages of labour; hospital routines, birth process and pain relief (led by therapist and midwife); becoming a family, changes in relationship, parenthood and enhancing mutual understanding between becoming parents; becoming a mother, recognising 
Table 4. Interventions targeted at women or families (Continued)

the signs of postnatal depression and bonding with the foetus; completing preparation for delivery and birth plan.

- Meeting two to three months after delivery with newborns, discussion of delivery experiences, detection of trauma and depression symptoms, discussion of mother-infant relationship.

Saisto 2001

\section{Sharifirad 2013}

Prenatal education for husbands

Intensive group therapy (cognitive behavioural therapy and childbirth psychotherapy)
- Intensive group therapy by obstetrician who had attended a 185 -hour course of cognitive therapy, 40 hours in childbirth psychology and was qualified as a therapist in addition to several years' experience in treating women suffering from fear of childbirth.

- Therapy comprised of provision of information and conversation regarding previous obstetric experiences, feelings and misconceptions. Appointments for the group therapy were based on routine obstetric check-ups to assure the normal course of pregnancy. All women allowed to phone for advice between sessions. Written information on the pros and cons of vaginal delivery and modes of pain relief was provided.
- Husbands were divided into three 13- to 15 -member groups; and each group participated in an educational session for 90 minutes.

- Educational content was about mechanism of natural vaginal and caesarean deliveries as well as their advantages and disadvantages.

- Various educational methods (lecture with picture slides, question, and answer) and educational tools (overhead, pamphlet, and white board) were used. No educational session was held for pregnant women.

- The training was done by a 'MSc expert' in health education.

\section{Shorten 2005}

Decision-aid booklet
- Decision-aid booklet constructed using the Ottawa Decision Framework (O'Connor 1999) as a format, incorporating evidence-based information, explicit probability illustrations and values clarification exercises.

- Presents risks and benefits in a format that encourages the user to make individual judgments about the information, according to personal values, needs and priorities.

- Decision booklet given at 28 weeks gestation.
Valiani 2014
Childbirth training workshop
- The educational workshop was held in three, four-hour sequential weekly sessions in groups of 30 members separately.

- Lecture method, questions and answers, role play, problem solving, and educational pamphlets were used to promote subjects' knowledge and group dynamicity, as well as to attain the highest participation of the subjects.

- Educational content included issues on couples' communication, parental role, the role of the spouse in mother's selection of delivery mode, attendance of the spouse or a relative at delivery stages, childbirth fear, delivery pain, delivery mechanism, medicational pain relief techniques and their effects, non-medicational pain relief methods, advantages and disadvantages of CS and vaginal delivery, indications and contraindications of CS, haemorrhage and infection after every mode of delivery, postpartum sorrow and depression, mother-infant attachment, breast feeding, and infants' intelligence, growth, and development.

Wang $2014 \quad$ PFMT with telephone
follow-up
- PFMT course topics included the female pelvic anatomy, the function of the female pelvic floor muscles, causes of pelvic floor muscle dysfunction, and possible symptoms. Using a discussion teaching method, the nurse explained the influence of pregnancy and delivery on the function of the pelvic floor muscles, the benefits of controlling maternal and foetal body weight, and how to perform PFMT. Women were given guidance in the correct muscle contraction method by a pelvic floor physiotherapist while performing pelvic floor muscle strength measurements during the first antenatal examination. 
Table 4. Interventions targeted at women or families (Continued)

- Programme details: training could be conducted at any time of day in a standing, supine, or sitting position. The women were asked to empty the bladder and then contract the anal and vaginal muscles for no less than three seconds. The muscles were then relaxed. This contraction-relaxation sequence was repeated twice and followed by five rapid contractions of the perineal muscles. Women were instructed to repeat the exercises for 10 to 15 minutes, two to three times a day; alternatively, contraction of the perineal muscles could be conducted 150 to 200 times per day at any time. The women were told to gradually prolong the duration of each contraction and the total training time. If the women felt unwell during the training, they were instructed to immediately stop the contraction movements.

- The test group was followed up by telephone every two weeks until six weeks postpartum; they were given a one-on-one consultation regarding any problems or questions that may have arisen during their home practice, and they were encouraged to persistently practice PFMT at home.

- The PFMT course was delivered in one session instructed by one full-time health education nurse.

ACOG: American College of Obstetricians and Gynecologists; CS: caesarean section; PFMT: pelvic floor muscle training; SD: standard deviation; VBAC: vaginal birth after caesarean 


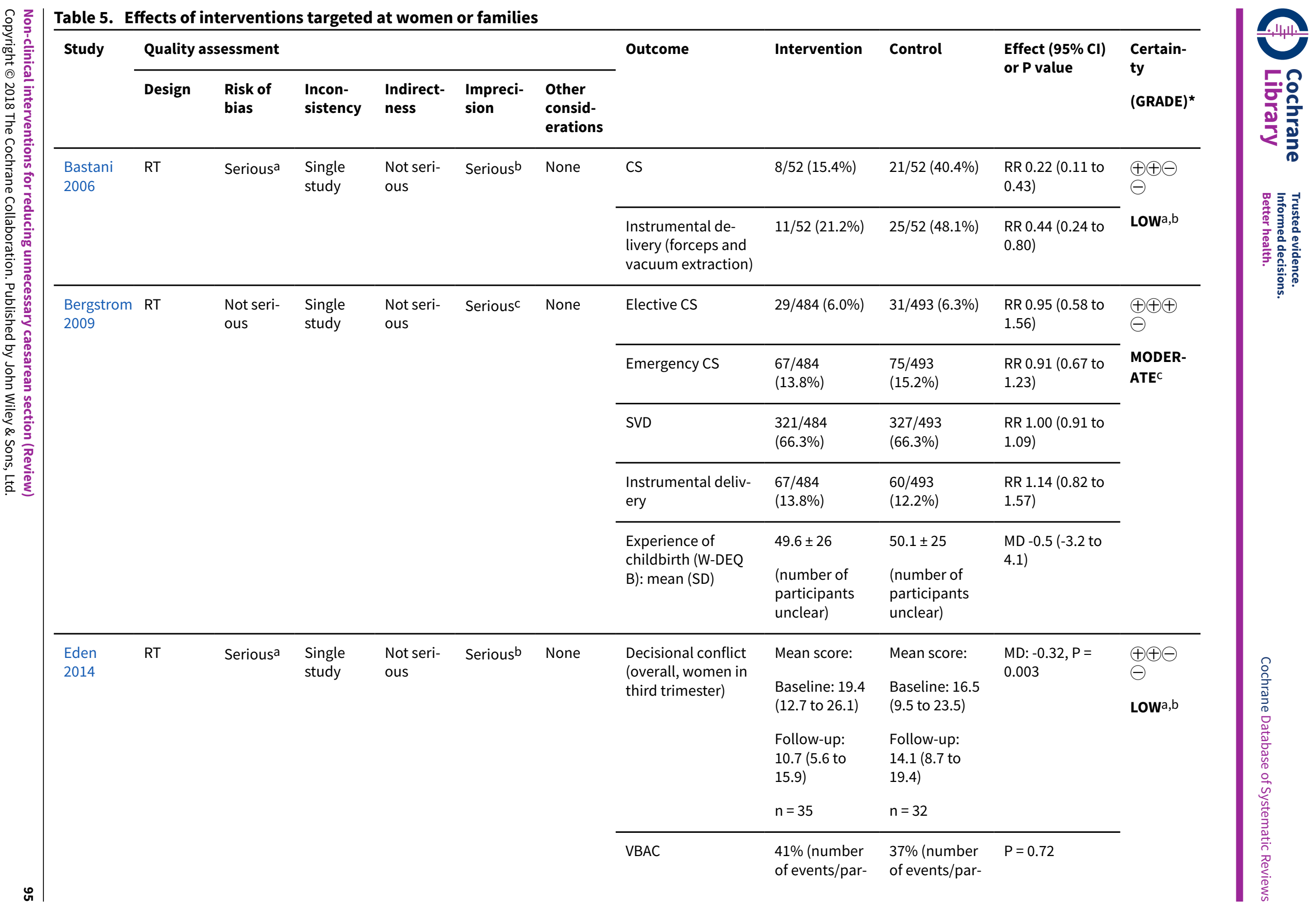




\begin{tabular}{|c|c|c|c|c|c|c|c|c|c|c|c|}
\hline & & & & & & & & $\begin{array}{l}\text { ticipants un- } \\
\text { clear) }\end{array}$ & $\begin{array}{l}\text { ticipants un- } \\
\text { clear) }\end{array}$ & & \\
\hline \multirow[t]{3}{*}{$\begin{array}{l}\text { Feinberg } \\
2015\end{array}$} & \multirow[t]{3}{*}{ RT } & \multirow[t]{3}{*}{ Serious ${ }^{a}$} & \multirow[t]{3}{*}{$\begin{array}{l}\text { Single } \\
\text { study }\end{array}$} & \multirow[t]{3}{*}{$\begin{array}{l}\text { Not seri- } \\
\text { ous }\end{array}$} & \multirow[t]{3}{*}{ Serious $^{b}$} & \multirow[t]{3}{*}{ None } & CS & $\begin{array}{l}21 \%(n=76) \\
\text { (number of } \\
\text { events un- } \\
\text { clear) }\end{array}$ & $\begin{array}{l}40 \%(n=71) \\
\text { (number of } \\
\text { events un- } \\
\text { clear) }\end{array}$ & $\begin{array}{l}\text { OR } 0.36 \text { ( } 0.15 \text { to } \\
0.86 \text { ) }\end{array}$ & \multirow[t]{3}{*}{$\begin{array}{l}\oplus \oplus \ominus \\
\ominus \\
\text { Lowa,b }\end{array}$} \\
\hline & & & & & & & $\begin{array}{l}\text { Maternity length of } \\
\text { stay (days) (mean, } \\
\text { SD) }\end{array}$ & $\begin{array}{l}3.11 \pm 2.09(\mathrm{n} \\
=76)\end{array}$ & $\begin{array}{l}3.36 \pm 2.50(\mathrm{n} \\
=71)\end{array}$ & $\begin{array}{l}\text { MD }-0.25(-1.00 \\
\text { to } 0.50)\end{array}$ & \\
\hline & & & & & & & $\begin{array}{l}\text { Newborn length of } \\
\text { stay (days) (mean, } \\
\text { SD) }\end{array}$ & $\begin{array}{l}2.67 \pm 1.04(\mathrm{n} \\
=76)\end{array}$ & $\begin{array}{l}2.89 \pm 1.17(\mathrm{n} \\
=71)\end{array}$ & $\begin{array}{l}\text { MD }-0.22(-0.58 \\
\text { to } 0.14)\end{array}$ & \\
\hline \multirow[t]{9}{*}{$\begin{array}{l}\text { Fenwick } \\
2015\end{array}$} & \multirow[t]{9}{*}{ RT } & \multirow[t]{9}{*}{ Serious ${ }^{a}$} & \multirow[t]{9}{*}{$\begin{array}{l}\text { Single } \\
\text { study }\end{array}$} & \multirow[t]{9}{*}{ Serious ${ }^{d}$} & \multirow[t]{9}{*}{ Serious $b$} & \multirow[t]{9}{*}{ None } & Overall CS & $31 / 91(34.1 \%)$ & $39 / 93(41.9 \%)$ & $\begin{array}{l}\text { RR } 0.81 \text { ( } 0.56 \text { to } \\
1.18 \text { ) }\end{array}$ & \multirow{9}{*}{$\begin{array}{l}\oplus \ominus \ominus \\
\ominus \\
\text { VERY } \\
\text { LOWa,b,c }\end{array}$} \\
\hline & & & & & & & Emergency CS & $16 / 91(17.6 \%)$ & $23 / 91(24.7 \%)$ & $\begin{array}{l}\mathrm{RR} 0.70 \text { ( } 0.39 \text { to } \\
1.23 \text { ) }\end{array}$ & \\
\hline & & & & & & & SVD & $44 / 91(48.4 \%)$ & $39 / 93(41.9 \%)$ & $\begin{array}{l}\text { RR } 1.15 \text { ( } 0.84 \text { to } \\
1.59)\end{array}$ & \\
\hline & & & & & & & $\begin{array}{l}\text { Forceps and vacu- } \\
\text { um delivery }\end{array}$ & $16 / 91(17.6 \%)$ & $15 / 93(16.1 \%)$ & $\begin{array}{l}\text { RR } 1.09 \text { ( } 0.57 \text { to } \\
2.07 \text { ) }\end{array}$ & \\
\hline & & & & & & & Nursery admission & $16 / 91(17.6 \%)$ & $18 / 91(19.4 \%)$ & $\begin{array}{l}\text { RR } 0.89 \text { ( } 0.48 \text { to } \\
1.63)\end{array}$ & \\
\hline & & & & & & & $\begin{array}{l}\text { Maternal readmis- } \\
\text { sion }\end{array}$ & $3 / 91(3.3 \%)$ & $5 / 91(5.4 \%)$ & $\begin{array}{l}\text { RR } 0.60 \text { ( } 0.15 \text { to } \\
2.44)\end{array}$ & \\
\hline & & & & & & & Baby readmission & $8 / 91(8.8 \%)$ & $6 / 91(6.5 \%)$ & $\begin{array}{l}\text { RR } 1.33 \text { ( } 0.48 \text { to } \\
3.69 \text { ) }\end{array}$ & \\
\hline & & & & & & & $\begin{array}{l}\text { Breastfeeding at } 6 \\
\text { months }\end{array}$ & $76 / 91(83.5 \%)$ & $73 / 91(78.5 \%)$ & $\begin{array}{l}\text { RR } 1.04 \text { ( } 0.91 \text { to } \\
1.19 \text { ) }\end{array}$ & \\
\hline & & & & & & & $\begin{array}{l}\text { Satisfaction with } \\
\text { mode of birth }\end{array}$ & $53 / 91(58.2 \%)$ & $61 / 91(65.6 \%)$ & $\begin{array}{l}\mathrm{RR} 0.87 \text { (0.69 to } \\
1.09 \text { ) }\end{array}$ & \\
\hline
\end{tabular}




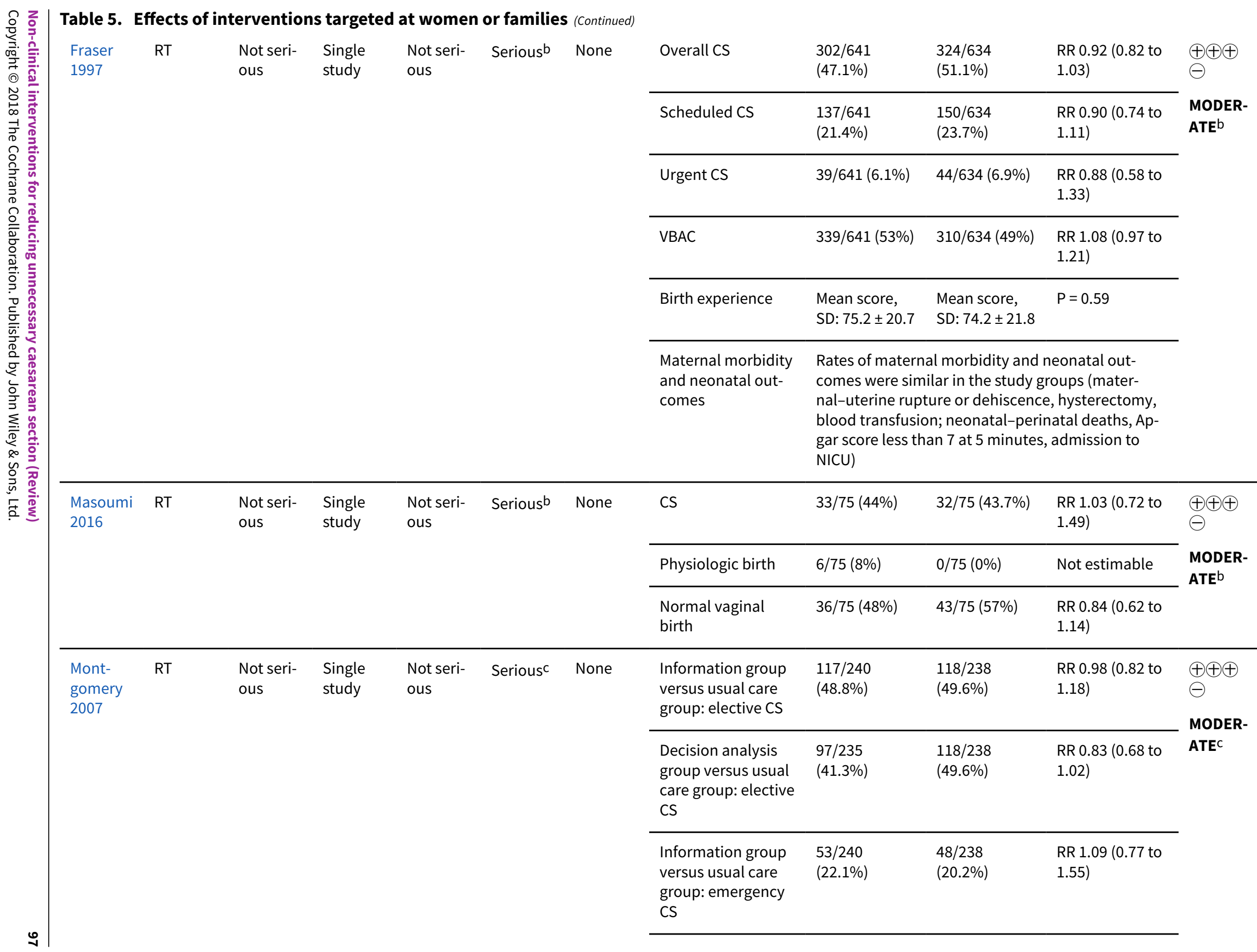




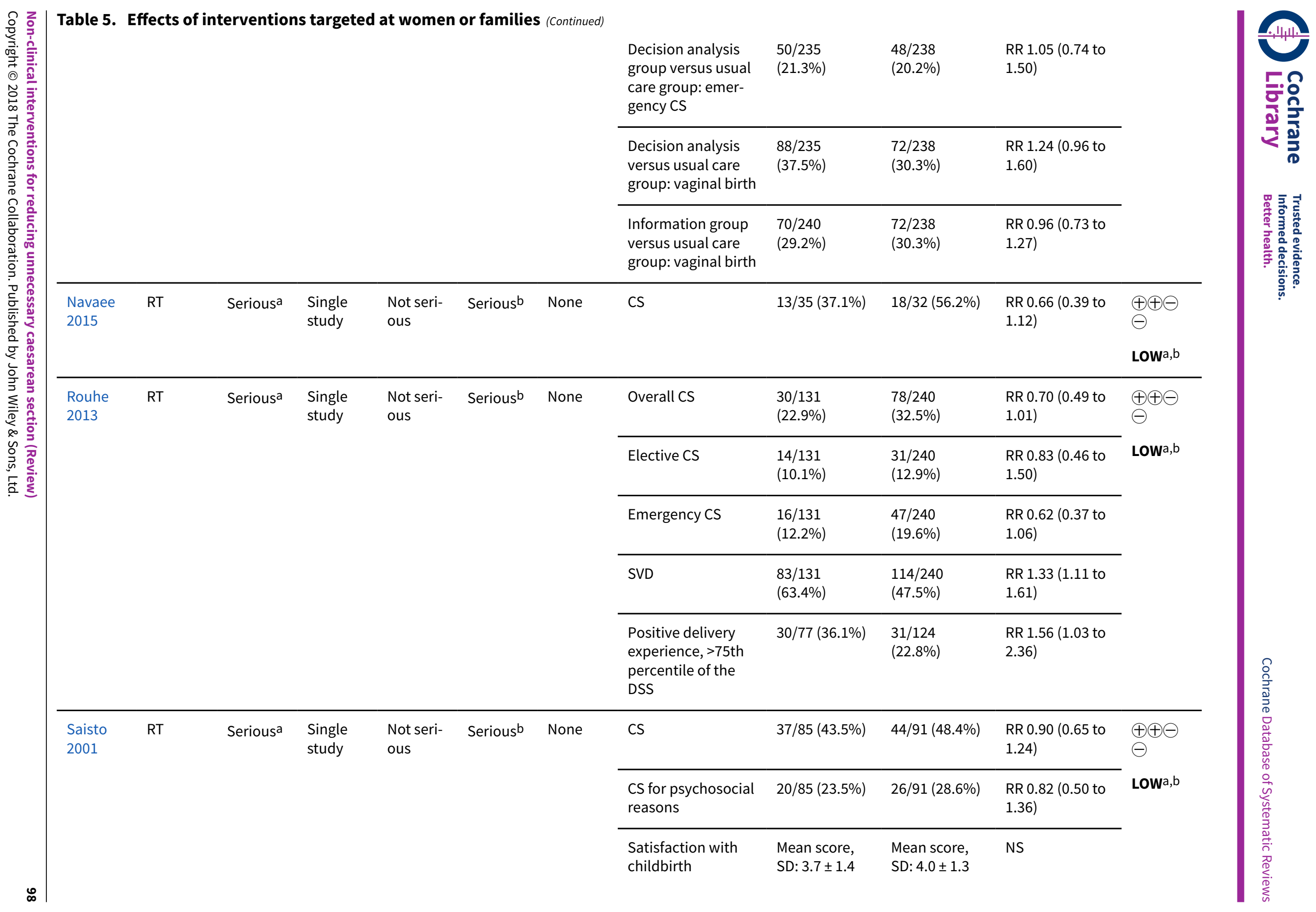




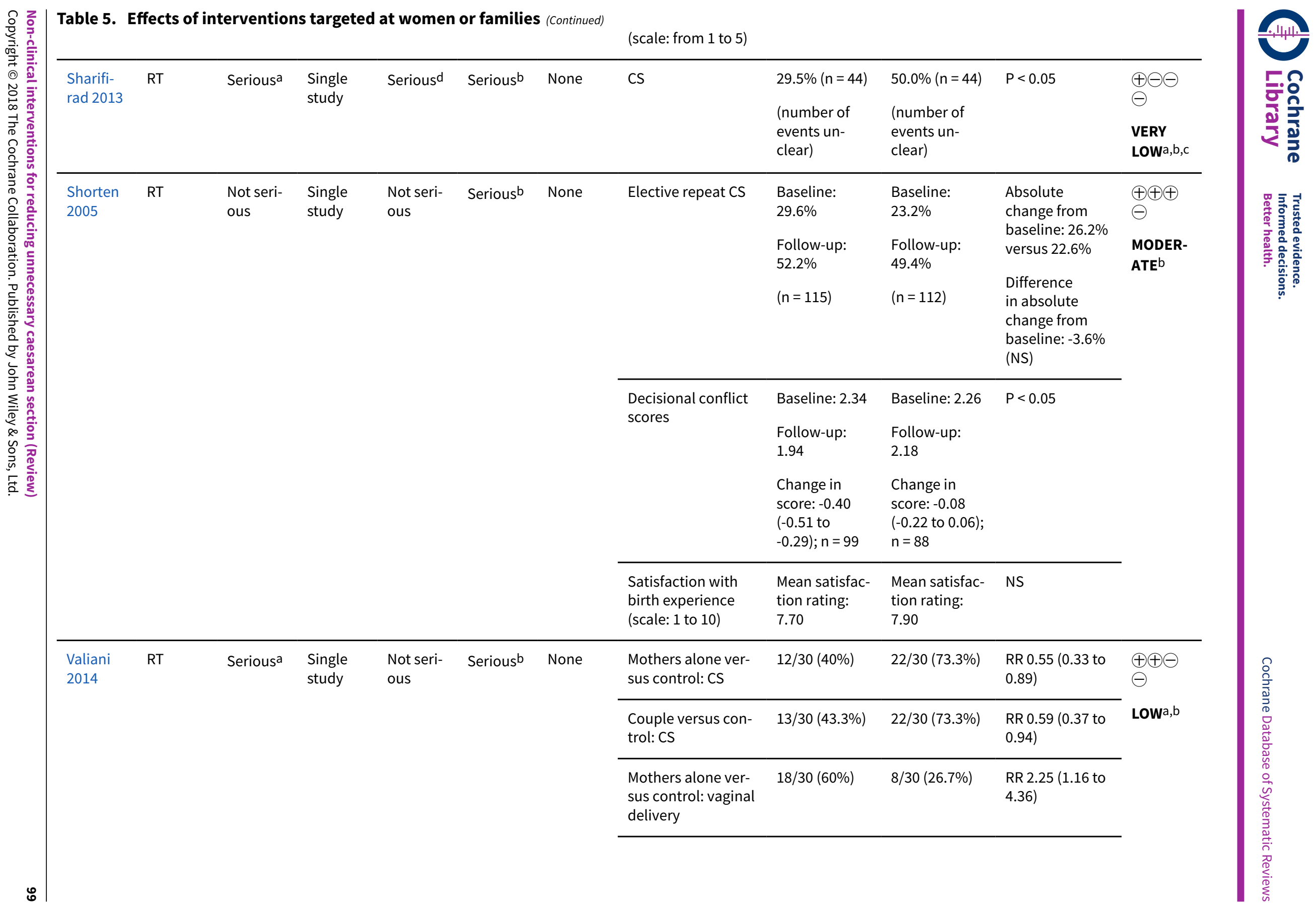




\begin{tabular}{|c|c|c|c|c|c|c|c|c|c|c|c|}
\hline & & & & & & & $\begin{array}{l}\text { Couple versus con- } \\
\text { trol: vaginal deliv- } \\
\text { ery }\end{array}$ & $17 / 30(56.7 \%)$ & $8 / 30(26.7 \%)$ & $\begin{array}{l}\text { RR } 2.13 \text { ( } 1.09 \text { to } \\
4.16 \text { ) }\end{array}$ & \\
\hline \multirow[t]{6}{*}{$\begin{array}{l}\text { Wang } \\
2014\end{array}$} & \multirow[t]{6}{*}{ RT } & \multirow[t]{6}{*}{ Serious ${ }^{a}$} & \multirow[t]{6}{*}{$\begin{array}{l}\text { Single } \\
\text { study }\end{array}$} & \multirow[t]{6}{*}{$\begin{array}{l}\text { Not seri- } \\
\text { ous }\end{array}$} & \multirow[t]{6}{*}{ Serious ${ }^{b}$} & \multirow[t]{6}{*}{ None } & Overall CS & $16 / 35(31.4 \%)$ & $27 / 55$ (49.1\%) & $\begin{array}{l}\text { RR } 0.87 \text { (0.37 to } \\
2.04 \text { ) }\end{array}$ & \multirow{6}{*}{$\begin{array}{l}\oplus \oplus \ominus \\
\ominus \\
\text { Lowa,b }\end{array}$} \\
\hline & & & & & & & Episiotomy & $\begin{array}{l}47.1 \% \text { (num- } \\
\text { ber of events/ } \\
\text { participants } \\
\text { unclear) }\end{array}$ & $\begin{array}{l}47.3 \% \text { (num- } \\
\text { ber of events/ } \\
\text { participants } \\
\text { unclear) }\end{array}$ & $P=0.35$ & \\
\hline & & & & & & & Perineal laceration & $\begin{array}{l}7.8 \% \text { (number } \\
\text { of events/par- } \\
\text { ticipants un- } \\
\text { clear) }\end{array}$ & $\begin{array}{l}3.6 \% \text { (number } \\
\text { of events/par- } \\
\text { ticipants un- } \\
\text { clear) }\end{array}$ & $P=0.98$ & \\
\hline & & & & & & & $\begin{array}{l}\text { Couple versus con- } \\
\text { trol: CS }\end{array}$ & $13 / 30(43.3 \%)$ & $22 / 30(73.3 \%)$ & $\begin{array}{l}\text { RR } 0.59 \text { ( } 0.37 \text { to } \\
0.94)\end{array}$ & \\
\hline & & & & & & & $\begin{array}{l}\text { Mothers alone ver- } \\
\text { sus control: vaginal } \\
\text { delivery }\end{array}$ & $18 / 30(60 \%)$ & $8 / 30(26.7 \%)$ & $\begin{array}{l}\text { RR } 2.25 \text { ( } 1.16 \text { to } \\
4.36 \text { ) }\end{array}$ & \\
\hline & & & & & & & $\begin{array}{l}\text { Couple versus con- } \\
\text { trol: vaginal deliv- } \\
\text { ery }\end{array}$ & $17 / 30(56.7 \%)$ & $8 / 30(26.7 \%)$ & $\begin{array}{l}\text { RR } 2.13 \text { (1.09 to } \\
4.16 \text { ) }\end{array}$ & \\
\hline
\end{tabular}

About the certainty of the evidence (GRADE) ${ }^{*}$

High: this research provides a very good indication of the likely effect; the likelihood that the effect will be substantially different ${ }^{\dagger}$ is low.

Moderate: this research provides a good indication of the likely effect; the likelihood that the effect will be substantially different ${ }^{\dagger}$ is moderate.

Low: this research provides some indication of the likely effect; however, the likelihood that it will be substantially different ${ }^{\dagger}$ is high.

Very low: this research does not provide a reliable indication of the likely effect; the likelihood that the effect will be substantially different ${ }^{\dagger}$ is very high.

*This is sometimes referred to as 'quality of evidence' or 'confidence in the estimate'

†Substantially different $=$ a large enough difference that it might affect a decision

DSS: delivery satisfaction scale; MD: mean difference; NICU: neonatal intensive care unit; NS: not significant; OR: odds ratio; RR: risk ratio; RT: randomised trial; SD: standard deviation; SVD: spontaneous vaginal delivery; VBAC: vaginal birth after cesarean; W-DEQ B Wijma Delivery Expectancy/Experience Questionnaire-Version B.

aDowngraded one level for serious risk of bias (due to flaws in randomisation procedures). 


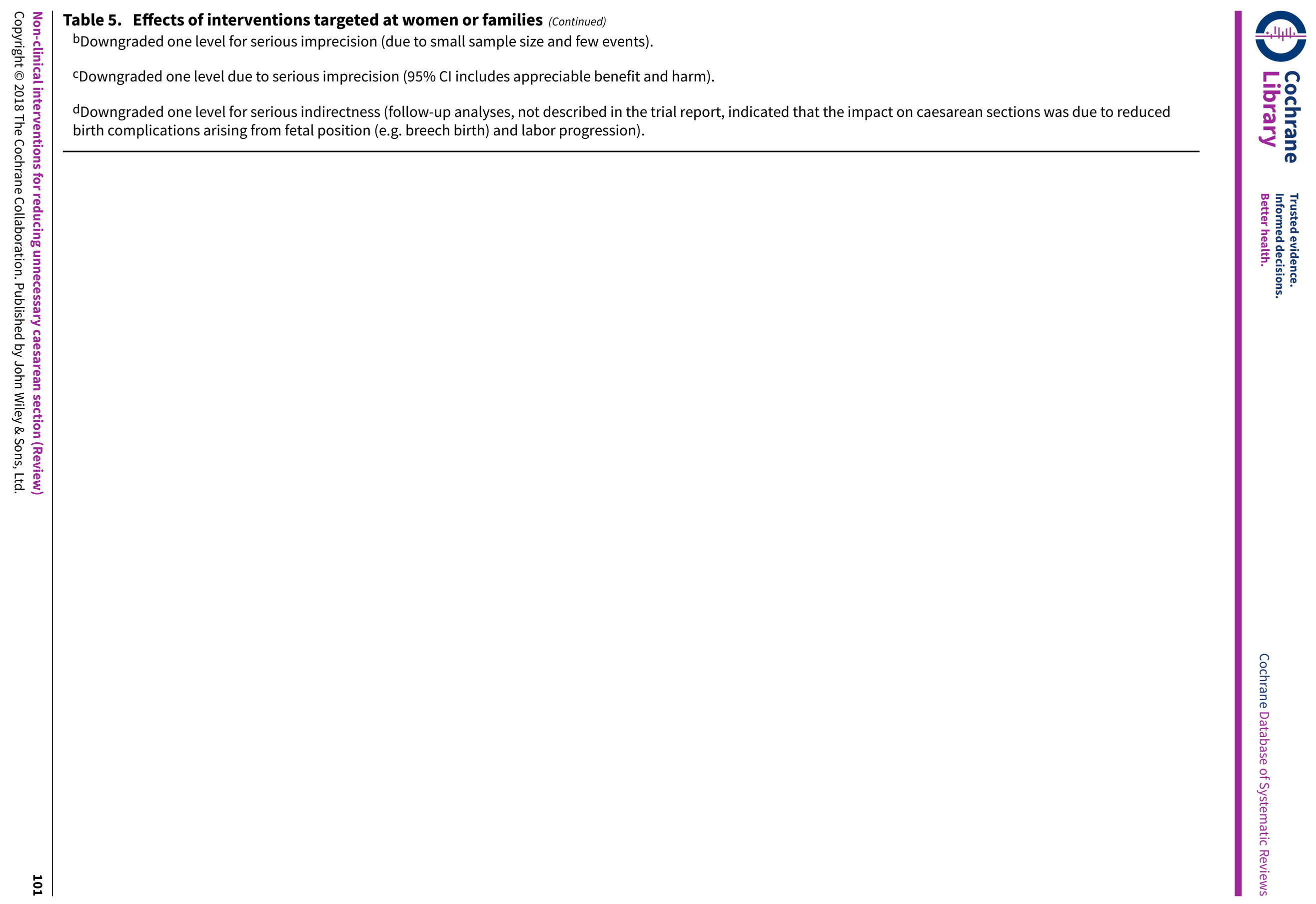


Table 6. Interventions targeted at healthcare professionals

\begin{tabular}{lll}
\hline Study & Intervention & Details \\
\hline Althabe 2004 & $\begin{array}{l}\text { Evidence-based guide- } \\
\text { lines plus mandatory } \\
\text { second opinion }\end{array}$ & $\begin{array}{l}\text { Mandatory second opinion by attending physician before caesarean section. } \\
\text { Physician providing second opinion had to be a person with clinical qualifi- } \\
\text { cations equal to or higher than the attending physician, working at the same } \\
\text { hospital, selected by the obstetrics department for the trial and who agreed } \\
\text { to follow the clinical guidelines. Guidelines were prepared as decision flow- } \\
\text { charts for six primary indications for caesarean section. }\end{array}$
\end{tabular}

Chaillet $2015 \quad$ Evidence-based guidelines plus audit and feedback
- Implementation of evidence-based guidelines (onsite training in evidence-based clinical practice, facilitation by local opinion leader, supervision), audits of indications for caesarean delivery and provision of feedback to health professionals.
Hemminki 2008
Education of public health nurses on childbirth classes
- Further training of public health nurses to pay more attention to mode of delivery in childbirth classes and informational material given to pregnant women.

- Intervention consisted of: a) joint educational session (1.5 to 2 hours) to all public health nurses in the maternal health clinic by experienced midwifery teacher using instructional conversation in small groups; b) leaflet on childbirth and preparation to give to pregnant women including discussion of content during childbirth classes and other visits from week 32 onwards; c) file of evidence-based research material on the same topics for each maternal health clinic; and d) a questionnaire to public health nurses on their opinions and knowledge of childbirth before each educational session.

$\begin{array}{ll}\text { Liang } 2004 & \begin{array}{l}\text { Peer review plus } \\ \text { mandatory second } \\ \text { opinion }\end{array}\end{array}$

Lomas 1991
Audit and feedback plus local opinion leader education
- Peer review included pre-caesarean consultation and post-caesarean surveillance. Two physicians appointed as consultants for the pre-caesarean surveillance. Second opinion by a consultant required for all caesarean sections. Every caesarean case presented at weekly meetings by chief resident.

- Audit and feedback group: a) agreed on criteria for use of caesarean section on women with previous caesarean sections based on guidelines; b) medical audits of the charts of all women with a previous caesarean section and comparison of actual practice with agreed criteria; and c) meetings of whole department every three months for feedback and discussion of the audit.

- Local opinion leader group: a) four physicians identified as opinion leaders through a survey of 300 physicians attended a one and a half-day workshop on evidence for practice guidelines and principles of behaviour change; $b$ ) two mailings to colleagues with information on the practice guidelines, with a letter of support from the local opinion leader; opinion leader hosted a meeting with an expert speaker with knowledge and credibility in the area of vaginal birth after caesarean section and maintained formal and informal educational contacts, recording these in a log book.

- Control group: mailed copy of practice guideline with exhortatory letter highlighting section on caesarean section portion of guideline, that the guideline was endorsed by the national obstetrical speciality society and a request to implement the recommendations.
Mohammadi 2012
Audit and feedback plus financial incentive
- Clinical audit and feedback; review of random sample of caesarean section patients for indication with financial incentive to practitioners who meet the criteria.

\section{Poma 1998}

Audit and feedback plus 24-hour in-house coverage by dedicated physician
- Implementation of labour management and caesarean delivery guidelines, with review of every caesarean delivery that did not meet guidelines and confidential individual feedback; 24 -hour in-house coverage established (attending physician on premises to manage labour and complications); and at- 
Table 6. Interventions targeted at healthcare professionals (Continued)

tempts made to achieve the goal of an annual caesarean delivery rate of less than $15 \%$.

Scarella 2011
Audit and feedback using the Robson classification (Robson 2001)
- Initial audit and feedback to the maternity and midwifery staff on main contributors to overall caesarean section rate using the Robson classification (examples of caesarean sections performed without clinical justification shown and discussed, emphasising the need to safely reduce the number of caesarean sections in the groups of interest).

- Caesarean section rate audited monthly following initial meeting; feedback on change in caesarean section rates, by individual letters provided to all staff.

- Medical-midwifery staff meetings held every three months; changes in caesarean section rate according to the Robson classification and rate of 5minute Apgar scores below 7 presented, as aggregate data and also divided according to the different duty-day shift that rotates through the week, ranking them from worst to best according to their caesarean section rates in the groups of interest. A report of the caesarean section data also provided by letter to every maternity staff member. 
Table 7. Effects of interventions targeted at healthcare professionals

\begin{tabular}{|c|c|c|c|c|c|c|c|c|c|c|c|}
\hline \multirow[t]{2}{*}{ Study } & \multicolumn{6}{|c|}{ Quality assessment } & \multirow{2}{*}{$\begin{array}{l}\text { Out- } \\
\text { come }\end{array}$} & \multirow[t]{2}{*}{ Intervention } & \multirow[t]{2}{*}{ Control } & \multirow{2}{*}{$\begin{array}{l}\text { Effect } \\
\text { Relative (95\% } \\
\text { Cla) or } P \text { value }\end{array}$} & \multirow{2}{*}{$\begin{array}{l}\text { Cer- } \\
\text { tainty } \\
\text { (GRADE }\end{array}$} \\
\hline & Design & $\begin{array}{l}\text { Risk of } \\
\text { bias }\end{array}$ & $\begin{array}{l}\text { Incon- } \\
\text { sisten- } \\
\text { cy }\end{array}$ & $\begin{array}{l}\text { Indi- } \\
\text { rect- } \\
\text { ness }\end{array}$ & $\begin{array}{l}\text { Impre- } \\
\text { cision }\end{array}$ & $\begin{array}{l}\text { Oth- } \\
\text { er con- } \\
\text { sidera- } \\
\text { tions }\end{array}$ & & & & & \\
\hline \multirow[t]{7}{*}{$\begin{array}{l}\text { Al- } \\
\text { thabe } \\
2004\end{array}$} & \multirow[t]{7}{*}{ RT } & \multirow[t]{7}{*}{$\begin{array}{l}\text { Not se- } \\
\text { rious }\end{array}$} & \multirow[t]{7}{*}{$\begin{array}{l}\text { Single } \\
\text { study }\end{array}$} & \multirow[t]{7}{*}{$\begin{array}{l}\text { Not se- } \\
\text { rious }\end{array}$} & \multirow[t]{7}{*}{$\begin{array}{l}\text { Not se- } \\
\text { rious }\end{array}$} & \multirow[t]{7}{*}{ None } & All CS & $\begin{array}{l}\text { Mean baseline rate }(34,735 \\
\text { women): } 26.3 \\
\text { Mean follow-up rate }(35,675) \text { : } \\
24.7 \\
\text { Mean rate change: }-1.6\end{array}$ & $\begin{array}{l}\text { Mean baseline rate } \\
(39,175 \text { women): } 24.6 \\
\text { Mean follow-up rate } \\
(39,638): 24.9 \\
\text { Mean rate change: } 0.3\end{array}$ & $\begin{array}{l}\text { Mean differ- } \\
\text { ence in rate } \\
\text { change: } \\
-1.9(-3.8 \text { to } \\
-0.1)\end{array}$ & $\begin{array}{l}\oplus \oplus \oplus \\
\oplus \\
\text { HIGH }\end{array}$ \\
\hline & & & & & & & $\begin{array}{l}\text { Elec- } \\
\text { tive CS }\end{array}$ & $\begin{array}{l}\text { Mean baseline rate }(34,735 \\
\text { women): } 8.9 \\
\text { Mean follow-up rate }(35,675) \text { : } \\
9.1\end{array}$ & $\begin{array}{l}\text { Mean baseline rate } \\
\text { (39,175 women): } 9.1 \\
\text { Mean follow-up rate } \\
(39,638): 9.0\end{array}$ & $\begin{array}{l}\text { Mean differ- } \\
\text { ence in rate } \\
\text { change: } 0.2 \\
(-1.4 \text { to } 1.8)\end{array}$ & \\
\hline & & & & & & & & Mean rate change: 0.1 & Mean rate change: -0.1 & & \\
\hline & & & & & & & $\begin{array}{l}\text { Intra- } \\
\text { partum } \\
\text { CS }\end{array}$ & $\begin{array}{l}\text { Mean baseline rate }(34,735 \\
\text { women): } 17.4 \\
\text { Mean follow-up rate }(35,675) \text { : } \\
15.6\end{array}$ & $\begin{array}{l}\text { Mean baseline rate } \\
(39,175 \text { women): } 15.4 \\
\text { Mean follow-up rate } \\
(39,638): 15.9\end{array}$ & $\begin{array}{l}\text { Mean differ- } \\
\text { ence in rate } \\
\text { change: }-2.2 \\
(-4.3 \text { to }-0.1)\end{array}$ & \\
\hline & & & & & & & & Mean rate change: -1.8 & Mean rate change: 0.4 & & \\
\hline & & & & & & & $\begin{array}{l}\text { Ma- } \\
\text { ternal } \\
\text { mor- } \\
\text { tality }\end{array}$ & $\begin{array}{l}\text { Mean baseline rate per } 10,000 \\
\text { livebirths ( } 34,735 \text { women): } 3.2 \\
\text { Mean follow-up rate per } 10,000 \\
\text { livebirths ( } 35,675 \text { women): } 4.3\end{array}$ & $\begin{array}{l}\text { Mean baseline rate per } \\
10,000 \text { livebirths }(39,175 \\
\text { women): } 5.9 \\
\text { Mean follow-up rate per } \\
\text { 10,000 livebirths }(39,638 \\
\text { women): } 7.5\end{array}$ & $\begin{array}{l}\text { Mean differ- } \\
\text { ence in rate } \\
\text { change: } \\
0.66 \text { (-0.4 } \\
\text { to } 5.3) \text { (re- } \\
\text { analysed) }\end{array}$ & \\
\hline & & & & & & & $\begin{array}{l}\text { Neona- } \\
\text { tal } \\
\text { mor- } \\
\text { tality }\end{array}$ & $\begin{array}{l}\text { Mean baseline rate }(34,735 \\
\text { women): } 1.1 \\
\text { Mean follow-up rate per } 10,000 \\
\text { livebirths ( } 35675 \text { women): } 0.9\end{array}$ & $\begin{array}{l}\text { Mean baseline rate } \\
\text { (39,175 women): } 1.1 \\
\text { Mean follow-up rate } \\
\text { (39,638 women): } 1.0\end{array}$ & $\begin{array}{l}\text { Mean differ- } \\
\text { ence in rate } \\
\text { change }(95 \% \\
\mathrm{Cl}) \text { : }\end{array}$ & \\
\hline
\end{tabular}




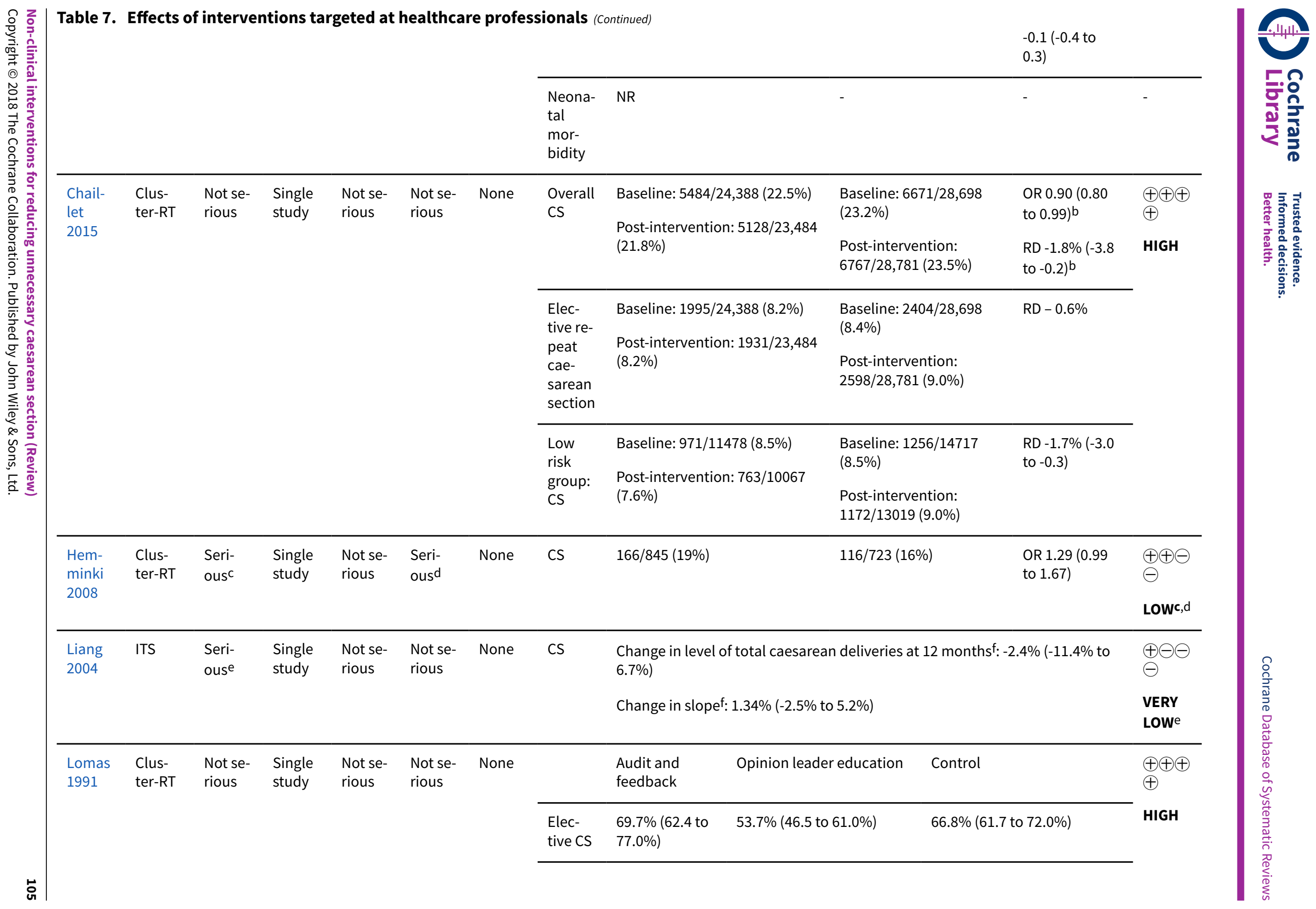




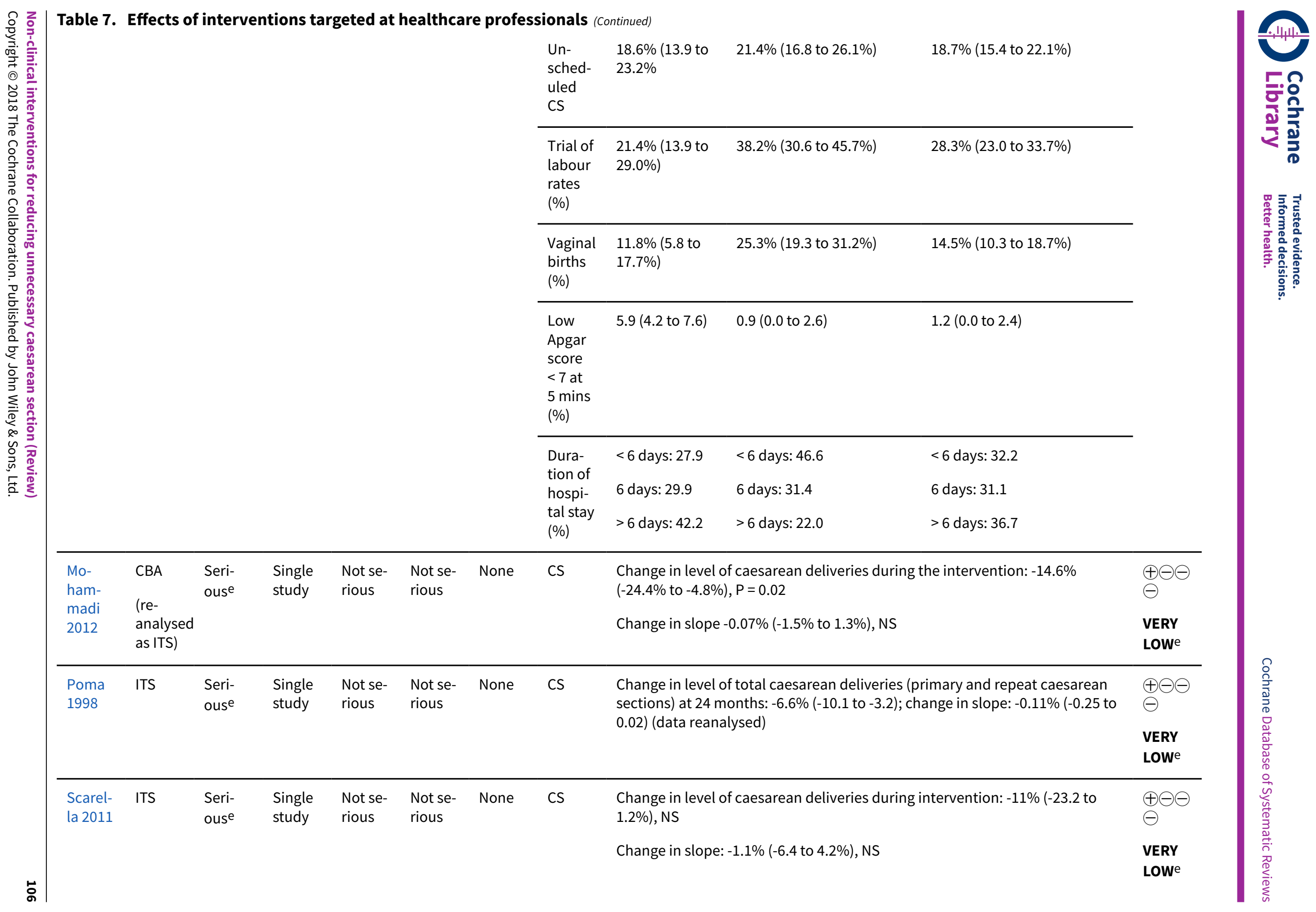


Table 8. Interventions targeted at healthcare organisations or facilities

Study Intervention Details

\section{Financial interventions targeted at healthcare professionals}

\begin{tabular}{lll}
\hline Keeler 1996 & $\begin{array}{l}\text { Equalising physician fees } \\
\text { for vaginal and caesarean } \\
\text { section delivery }\end{array}$ & $\begin{array}{l}\text { Revision to fee schedule for obstetric and other procedures including equal- } \\
\text { ising the fees for vaginal and caesarean sections. }\end{array}$ \\
\hline Lo 2008 & $\begin{array}{l}\text { Increase physician fees } \\
\text { for VBAC fee to the same } \\
\text { level as caesarean sec- } \\
\text { tion }\end{array}$ & $\begin{array}{l}\text { National Health Insurance Taiwan equalised the fee for VBAC to that of a } \\
\text { caesarean in April 2003. In May 2005, the fee for vaginal birth was raised to } \\
\text { the equivalent of that of a caesarean section. }\end{array}$ \\
& $\begin{array}{l}\text { Increase in vaginal birth } \\
\text { physician fees to that of } \\
\text { caesarean section }\end{array}$
\end{tabular}

\section{Staffing model interventions}

\begin{tabular}{lll} 
Rosenstein 2015 & $\begin{array}{l}\text { Expanded access to col- } \\
\text { laborative 24-hour mid- } \\
\text { wifery-labourist care mod- } \\
\text { el }\end{array}$ & $\begin{array}{l}\text { Expansion of a labourist model that includes 24-hour in-hospital midwifery } \\
\text { coverage to privately insured patients ('labourist', generally designates an } \\
\text { obstetrician who provides in-house labour and delivery coverage without } \\
\text { competing clinical duties). }\end{array}$ \\
& $\begin{array}{l}\text { One midwife and one labourist present in-house, } 24 \text { hours a day, working } \\
\text { collaboratively to provide primary labour management for all private and } \\
\text { public patients. }\end{array}$ \\
\hline Srinivas 2016 & $\begin{array}{l}\text { Labourist model of obstet- } \\
\text { ric care }\end{array}$ & $\begin{array}{l}\text { Labourist model of obstetric care: presence of a labour and delivery } \\
\text { livery unit without other competing clinical duties. The labourist model was } \\
\text { based on the internal medicine hospitalist model where physicians spend }> \\
25 \% \text { of their time caring for inpatients. }\end{array}$ \\
\hline
\end{tabular}

VBAC: vaginal birth after caesarean 
Table 9. Effects of interventions targeted at healthcare organisations or facilities

\begin{tabular}{|c|c|c|c|c|c|c|c|c|c|c|c|}
\hline \multirow[t]{2}{*}{ Study } & \multicolumn{6}{|c|}{ Quality assessment } & \multirow{2}{*}{$\begin{array}{l}\text { Out- } \\
\text { come }\end{array}$} & \multirow[t]{2}{*}{ Intervention } & \multirow[t]{2}{*}{ Control } & \multirow{2}{*}{$\begin{array}{l}\text { Relative ef- } \\
\text { fect ( } 95 \% \\
\text { CI) }\end{array}$} & \multirow{2}{*}{$\begin{array}{l}\text { Certain- } \\
\text { ty } \\
\text { (GRADE) }\end{array}$} \\
\hline & Design & $\begin{array}{l}\text { Risk of } \\
\text { bias }\end{array}$ & $\begin{array}{l}\text { Incon- } \\
\text { sistency }\end{array}$ & $\begin{array}{l}\text { Indirect- } \\
\text { ness }\end{array}$ & $\begin{array}{l}\text { Impreci- } \\
\text { sion }\end{array}$ & $\begin{array}{l}\text { Other } \\
\text { consid- } \\
\text { erations }\end{array}$ & & & & & \\
\hline
\end{tabular}

Effects of financial strategies targeted at healthcare professionals

\begin{tabular}{|c|c|c|c|c|c|c|c|c|}
\hline $\begin{array}{l}\text { Keeler } \\
1996\end{array}$ & ITS & Seriousa & $\begin{array}{l}\text { Single } \\
\text { study }\end{array}$ & $\begin{array}{l}\text { Not seri- } \\
\text { ous }\end{array}$ & $\begin{array}{l}\text { Not seri- } \\
\text { ous }\end{array}$ & None & $\mathrm{CS}$ & $\begin{array}{l}\text { CS rates for non-breech deliveries decreased by } 1.2 \% \text { ( } 22.5 \% \\
\text { before reform versus } 21.3 \% \text { after reform) }\end{array}$ \\
\hline
\end{tabular}

study

ous

ous

before reform versus $21.3 \%$ after reform

$\ominus$

VERY

LOWa

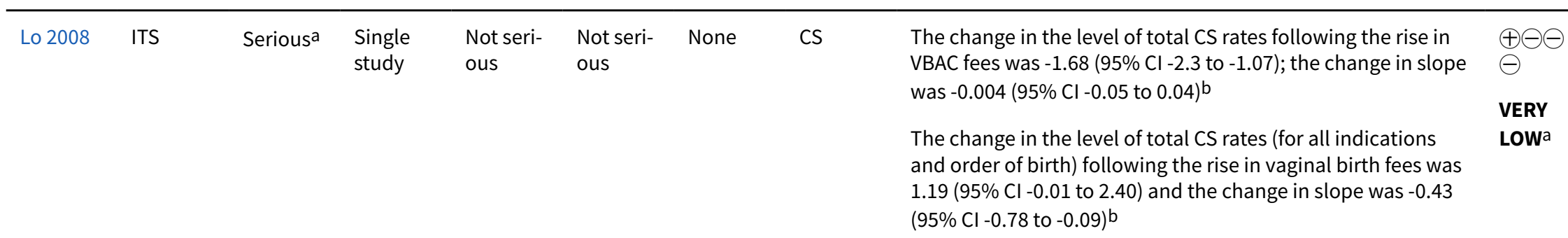

Effects of different staffing models of care

Cohort Not seri- Single Not seri- Not seri- None

Primary Before expansion: After expansion:

OR 0.56

$\oplus \oplus \ominus$

2015 analysis

ous ous

CS

$381 / 1201(31.7 \%)$

$130 / 521(25.0 \%)$

(0.39 to

$\ominus$

0.81

VBAC

Before expansion:

After expansion:

OR 2.03

$60 / 452(13.3 \%)$

$52 / 232(22.4 \%)$

Lowc

Srinivas CBA Not seri- Single Not seri- Not seri- None

CS

Labourist before, $\%$

Non-labourist before,

3.80)

2016

ous

study

ous

Labourist after, \% Non-labourist after, \%

$\%(\mathrm{~N}): 28.5(46,486)$

OR 1.02

$\oplus \oplus \ominus$

Low

$\begin{array}{ll}(N): 33.6(35,210) & (N): 31.8(42,348)\end{array}$

Labourist before, \% Non-labourist before, $\quad$ OR 1.07

$(\mathrm{N}): 3.8(5549) \quad \%(\mathrm{~N}): 6.2(10,018) \quad$ (0.88 to

Labourist after, \% Non-labourist before,

$(\mathrm{N}): 3.5(3814) \quad \%(\mathrm{~N}): 4.8(6339)$ 
Table 9. Effects of interventions targeted at healthcare organisations or facilities (Continued)

\begin{tabular}{|c|c|c|c|}
\hline $\begin{array}{l}\text { Low Ap- } \\
\text { gar (less } \\
\text { than } 7 \text { ) } \\
\text { at } 5 \text { min- } \\
\text { utes }\end{array}$ & $\begin{array}{l}\text { Labourist before, \% } \\
(\mathrm{N}): 0.2(216) \\
\text { Labourist after, \% } \\
(\mathrm{N}): 0.2(223)\end{array}$ & $\begin{array}{l}\text { Non-labourist before, } \\
\%(\mathrm{~N}): 0.4(557) \\
\text { Non-labourist after, \% } \\
\text { (N): } 0.4(476)\end{array}$ & $\begin{array}{l}\text { OR } 1.09 \\
(0.69 \text { to } \\
1.72)\end{array}$ \\
\hline $\begin{array}{l}\text { Birth as- } \\
\text { phyxia }\end{array}$ & $\begin{array}{l}\text { Labourist before, \% } \\
(\mathrm{N}): 0.2(310) \\
\text { Labourist after, \% } \\
(\mathrm{N}): 0.2(171)\end{array}$ & $\begin{array}{l}\text { Non-labourist before, } \\
\%(\mathrm{~N}): 0.3(398) \\
\text { Non-labourist after, \% } \\
(\mathrm{N}) \text { : } \\
0.2(247)\end{array}$ & $\begin{array}{l}\text { OR } 0.75 \\
\text { (0.48 to } \\
1.18 \text { ) }\end{array}$ \\
\hline $\begin{array}{l}\text { Mater- } \\
\text { nal pro- } \\
\text { longed } \\
\text { length of } \\
\text { stay }\end{array}$ & $\begin{array}{l}\text { Labourist before, \% } \\
(\mathrm{N}): 21.4(31,002) \\
\text { Labourist after, \% } \\
(\mathrm{N}): 21.5(22,512)\end{array}$ & $\begin{array}{l}\text { Non-labourist before, } \\
\%(\mathrm{~N}): 24.2(39,354) \\
\text { Non-labourist after, \% } \\
(\mathrm{N}): 26.2(34,876)\end{array}$ & $\begin{array}{l}\text { OR } 0.99 \\
(0.87 \text { to } \\
1.14)\end{array}$ \\
\hline
\end{tabular}

About the certainty of the evidence (GRADE)*

High: this research provides a very good indication of the likely effect; the likelihood that the effect will be substantially different ${ }^{\dagger}$ is low.

Moderate: this research provides a good indication of the likely effect; the likelihood that the effect will be substantially different ${ }^{\dagger}$ is moderate.

Low: this research provides some indication of the likely effect; however, the likelihood that it will be substantially different ${ }^{\dagger}$ is high.

Very low: this research does not provide a reliable indication of the likely effect; the likelihood that the effect will be substantially different ${ }^{\dagger}$ is very high.

*This is sometimes referred to as 'quality of evidence' or 'confidence in the estimate'

†Substantially different $=$ a large enough difference that it might affect a decision

CBA: controlled before-after; CS: caesarean section; CI: confidence interval; ITS: interrupted time series; OR: odds ratio; VBAC: vaginal birth after caesarean.

aDowngraded one level for serious risk of bias (due to possible confounding of outcome, unclear whether the intervention occurred independently of other changes over time).

bTwo standardised effect sizes are obtained from ITS analysis: a change in level (also called 'step change') and a change in trend (also called 'change in slope') before and after the intervention. Change in level = difference between the observed level at the first intervention time point and that predicted by the pre-intervention time trend; change in trend = difference between post- and pre-intervention slopes. A negative change in level and slope indicates a reduction in CS rate.

cObservational study which start at low certainty evidence according to GRADE (we did not downgrade or upgrade the certainty of evidence) 
Table 10. 'Cross-cutting' interventions

\begin{tabular}{|c|c|c|}
\hline Study & Intervention & Details \\
\hline Ayres-De-Campos 2015 & $\begin{array}{l}\text { Transmission of infor- } \\
\text { mation and training of } \\
\text { healthcare profession- } \\
\text { als, together with the } \\
\text { inclusion of CS rates as } \\
\text { a criterion for hospital } \\
\text { funding }\end{array}$ & $\begin{array}{l}\text { Concerted action to reduce CS } \\
\text { - Regional CS committee visited all state-owned hospitals with CS rates above } \\
35 \% \text { and held meetings with the obstetric and midwifery staff to present data } \\
\text { on international CS rates, individual hospital comparisons, risks associated } \\
\text { with CS, financial aspects related with CS, and to share proposed measures to } \\
\text { decrease CS rates. Some of these measures required local implementation, } \\
\text { such as avoidance of labour inductions without a health indication before } 41 \\
\text { weeks of gestation; promotion of vaginal birth after caesarean; implementa- } \\
\text { tion of external cephalic version; and conduction of regular CS audits. } \\
\text { - Courses on intrapartum foetal monitoring and simulation-based training of } \\
\text { obstetric emergencies were organised in } 2010 \text { and } 2011 \text {, and made available } \\
\text { free of charge to healthcare professionals in state-owned hospitals. } \\
\text { - From } 2010 \text { onwards, an important percentage of hospital funding was in- } \\
\text { dexed to the annual CS rate, and individual targets were negotiated with each } \\
\text { state-owned hospital. }\end{array}$ \\
\hline
\end{tabular}

\begin{tabular}{|c|c|c|}
\hline Runmei 2012 & $\begin{array}{l}\text { Continuous quality } \\
\text { improvement pro- } \\
\text { gramme (education- } \\
\text { al programme for hos- } \\
\text { pital staff and women, } \\
\text { auditing surgeon prac- } \\
\text { tices, public health } \\
\text { education, monitor- } \\
\text { ing caesarean section } \\
\text { rates and neonatal out- } \\
\text { comes) }\end{array}$ & $\begin{array}{l}\text { Continuous quality improvement programme } \\
\text { Stage 1: January } 2005 \text { to December } 2006 \\
\text { - Educational programme for hospital staff } \\
\text { - Discouragement of unnecessary caesarean deliveries by: } \\
\text { * depriving surgeons of potential financial incentives for cesarean deliver- } \\
\text { ies } \\
\text { * reviewing indications for caesarean deliveries performed every day } \\
* \quad \text { implementing international guidelines on caesarean delivery (e.g. those } \\
\text { of the American or the Royal College of Obstetricians and Gynaecologists) } \\
* \text { improving labour monitoring and assessment } \\
\text { - Active promotion of public health education on the advantages of natural } \\
\text { delivery and the risks associated with caesarean deliveries among pregnant } \\
\text { women, both through antenatal school and the public media } \\
\text { Stage } 2 \text { (January to June 2007) } \\
\text { - Monitoring of risk-adjusted cesarean section rates } \\
\text { Stage } 3 \text { (Jan 2005-Dec 2011) } \\
\text { - Monitoring of neonatal outcomes }\end{array}$ \\
\hline
\end{tabular}

\section{CS: caesarean section}


Table 11. Effects of 'cross-cutting' interventions

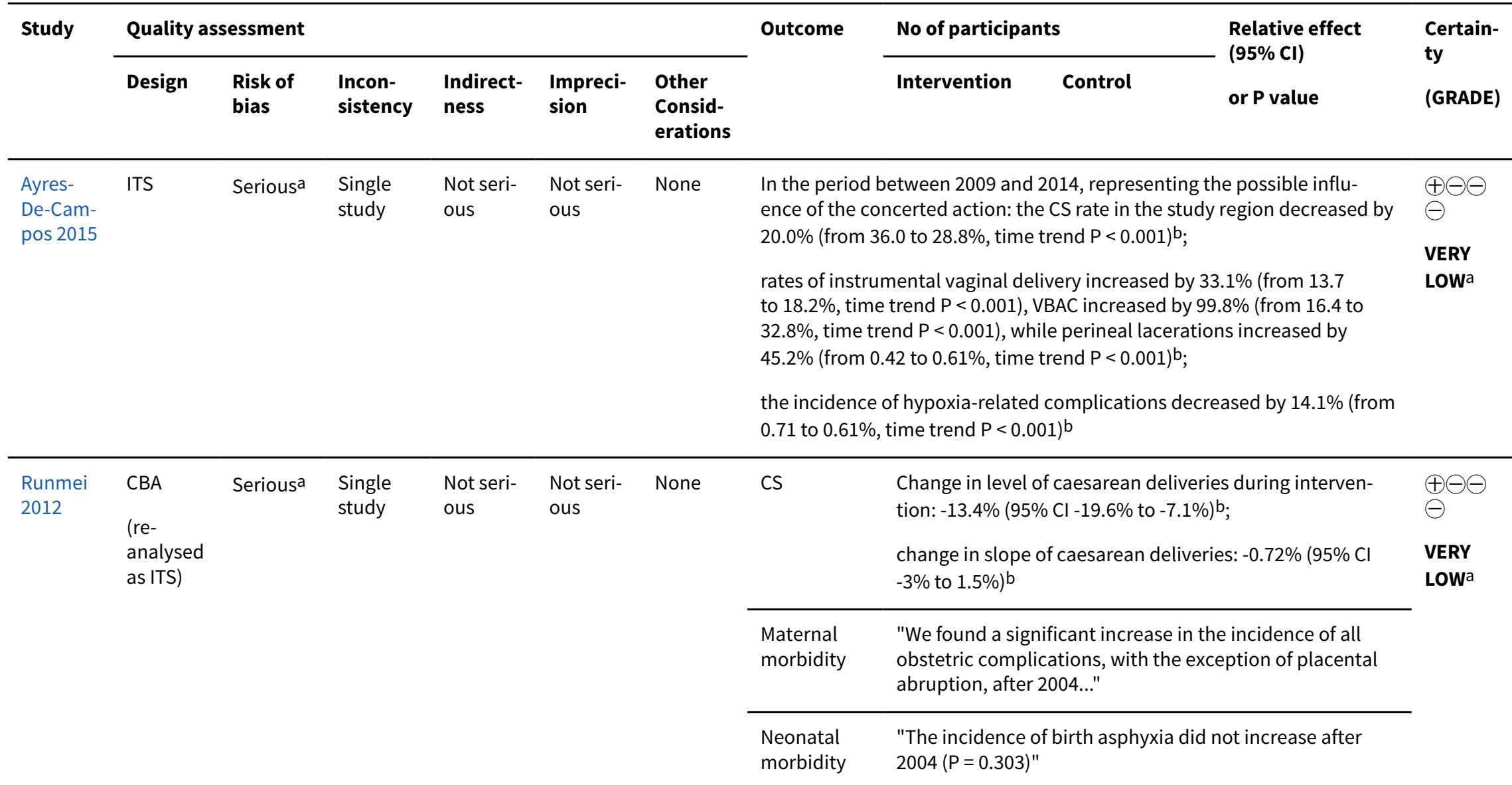

About the certainty of the evidence (GRADE) ${ }^{\star}$

High: this research provides a very good indication of the likely effect; the likelihood that the effect will be substantially different ${ }^{\dagger}$ is low.

Moderate: this research provides a good indication of the likely effect; the likelihood that the effect will be substantially different ${ }^{\dagger}$ is moderate.

Low: this research provides some indication of the likely effect; however, the likelihood that it will be substantially different ${ }^{\dagger}$ is high.

Very low: this research does not provide a reliable indication of the likely effect; the likelihood that the effect will be substantially different ${ }^{\dagger}$ is very high.

"This is sometimes referred to as 'quality of evidence' or 'confidence in the estimate'

†Substantially different $=$ a large enough difference that it might affect a decision

CBA: controlled before-after; Cl: confidence interval; CS: caesarean section; ITS: interrupted time series; VBAC: vaginal birth after caesarean. 


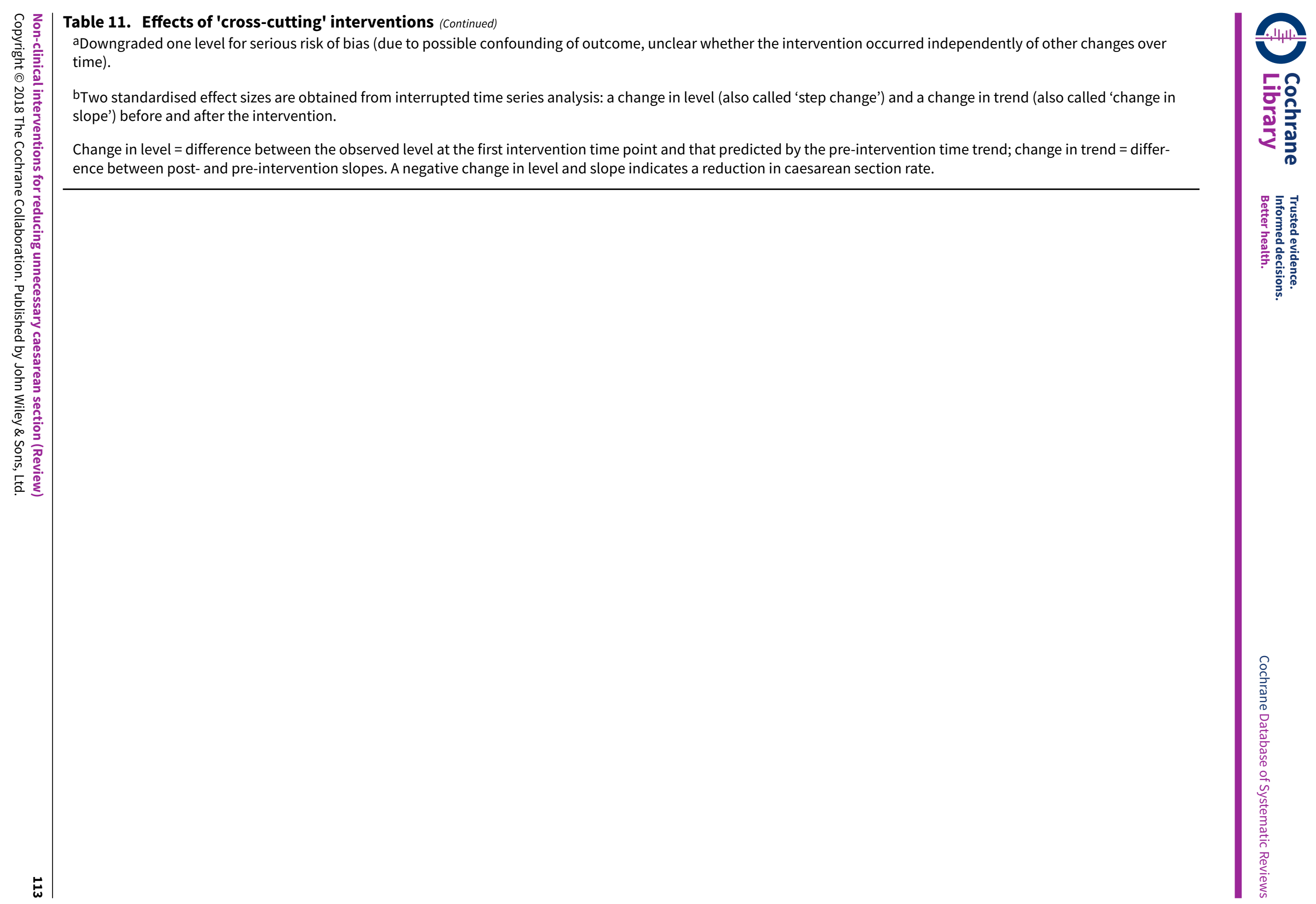




\section{Table 12. Related systematic reviews}

Boatin 2018 assessed the effect of audit and feedback using the Robson classification to reduce caesarean section rates. Studies (any design) that used the Robson classification within clinical audit cycles (including but not limited to strategies using audit and feedback) either alone or in multifaceted interventions to reduce caesarean section rate were eligible for inclusion. Six studies were included. All the studies used prospective uncontrolled before-after designs and none accounted for confounding, blinding or intervention integrity (i.e. the degree to which the participants received the intervention, and consistency of the intervention). All six studies reported reductions in caesarean section rates. The authors noted that the results should be interpreted with caution because of limited methodological quality of the included studies.

Catling-Paull 2011a assessed the effect of non-clinical interventions intended to increase the uptake or the success rates of VBAC, or both. Twenty-seven studies were included in the review (five randomised trials, one prospective cohort study, nine retrospective cohort studies, one case-control study and 11 before-after studies). The findings showed that national guidelines influence VBAC rates, but a greater effect is seen when institutions develop local guidelines, adopt a conservative approach to caesarean section, use opinion leaders, give individualised information to women, and give feedback to obstetricians about mode of birth rates.

Chaillet 2007 assessed the effectiveness of interventions intended to reduce cesarean section rate. Ten studies were included in the review (three randomised trials, two cluster-randomised trials and five interrupted time series studies). Audit and feedback, quality improvement, and multifaceted strategies were found to be effective for reducing the cesarean section rate.

Long 2016 assessed the effect of OMBUs embedded within hospitals which provide comprehensive emergency obstetric and newborn care. Three randomised trials, one controlled before-after study and six cohort studies were included in the review. Three cohort studies (one each from UK, China and Nepal) found more spontaneous vaginal deliveries, fewer caesarean sections and fewer episiotomies performed in OMBUs compared to standard obstetric units. There were no differences in these outcomes in randomised trials and the remaining cohorts. There were no or very few maternal and perinatal deaths in either OMBUs or standard obstetric units. One study reported higher satisfaction with midwife-led birth care among women and midwives in the OMBUs.

Lundgren 2015 assessed the effect of clinician-centred interventions designed to increase the rate of VBAC. Three randomised trials were included in the review. The use of external peer review, audit and feedback had no effect on VBAC rates. An educational strategy delivered by an opinion leader increased VBAC rates.

Nilsson 2015 assessed the effectiveness of women-centred interventions during pregnancy and birth to increase rates of VBAC. Randomised trials or cluster randomised trials were eligible for inclusion. Three trials were included in the review. Two studies evaluated the effectiveness of decision aids for mode of birth and one evaluated the effectiveness of an antenatal education programme. The findings show that neither the use of decision aids nor information/education of women have a significant effect on VBAC rates.

OMBU: onsite midwife-led birth units; VBAC: vaginal birth after caesarean.

\section{Table 13. Recommendations for future research}

\section{Further research should focus on the following areas}

Population Pregnant women who may be at risk of delivering by caesarean section without a medical indication or need

- Low-risk group of women (Robson Groups 1 to 4; Robson 2001)

- Women with a previous caesarean section (Robson Group 5)

Settings

- All areas with high or increasing caesarean section rates

- All settings where women receive maternity or delivery care (community, home, clinics, hospitals, birth centres)

\section{Study designs}

- Pragmatic randomised trials or cluster-randomised trials (involving clusters of practices, hospitals, birth centres, labour units). Where these are not feasible, interrupted time series designs should be used

- Studies should be sufficiently powered (include adequate sample sizes) for primary and secondary outcomes

- Include sufficient sample sizes to allow assessment of intervention effect by factors such as parity, socioeconomic status, staffing patterns, practice setting (private versus public), geographical region (urban versus rural), among others.

Non-clinical interventions for reducing unnecessary caesarean section (Review)

Copyright (c 2018 The Cochrane Collaboration. Published by John Wiley \& Sons, Ltd. 
Table 13. Recommendations for future research (Continued)

- Multisite studies are encouraged to increase sample size and generalisability

- Studies should be preceded with formative research to define main determinants of caesarean births

\section{Interventions}

Multifaceted (rather than single-component) interventions tailored to local determinants (facilitators) of caesarean section practices are recommended

The certainty of evidence for caesarean section rate was low to very low for the following interventions. Further studies are needed to address the uncertainty in the effect of these interventions

Educational interventions targeted at women or families

- Education, birth preparation classes and support programmes

- Psychoeducation by telephone

- Prenatal education for husbands of pregnant women

- Different formats of educational interventions (decision support tools)

Interventions targeted at healthcare professionals

- Audit and feedback using the Robson classification (Robson 2001)

- Education of public health nurses on childbirth classes (Hemminki 2008).

Interventions targeted at healthcare organisations or facilities

- Insurance reforms equalising physician fees for vaginal and caesarean deliveries

- Collaborative midwifery-labourist model of care

Although not specifically designed to reduce caesarean births, the following interventions examined in related reviews showed benefits in reducing caesarean births and improving other birth outcomes (further studies are required to confirm observed benefits in areas with high caesarean section rates)

- Continuous one-to-one intrapartum support (by nurse-midwives, lay companion and doulas)

- Midwifery care versus other care models (such as obstetric care)

We did not identify any eligible studies on the following prespecified interventions (outlined in Table 1); studies evaluating the effects of these interventions are needed.

Use of opinion leaders

- Dissemination of information or advocacy with support or campaigns from local or international opinion leaders (role models, leadership persons, public celebrities)

Public dissemination of caesarean section rates

- Informing the public about caesarean section rates by releasing performance data (e.g. for individual physicians or hospitals) in written or electronic form

Financial strategies for healthcare professionals or organisations

- Pay for performance (target payments)

- Payment for 24-hour shifts (not for number of procedures)

- Additional payment if caesarean section rate during shifts is maintained below a predefined threshold

Goal setting for caesarean section rates

- Setting specific predetermined goal for caesarean rate

Policies that limit financial/legal liability in case of litigation of healthcare professionals or organisations (tort reforms) 
Table 13. Recommendations for future research (Continued)

Changing the physical or sensory environment of labour and delivery

- Adding or altering equipment or layout

- Place of birth (planned home versus hospital births)

Strategies to change the organisational culture

- Strategies include various components of organisational culture, e.g. shared values, behaviours, norms, traditions, sense-making, which may shape or contribute, or both, to the overall environment of an organisation

Outcomes

\section{Methodological considera-} tions
- Limited data were available from the included studies on maternal mortality and morbidity, neonatal mortality and morbidity, resource use and costs. Future studies should address these outcomes to aid assessment of the desirable and undesirable effects of unnecessary caesarean sections.

- Studies should address both short-term and long-term maternal and neonatal outcomes.
Classification of caesarean section

- The included studies measured and reported caesarean sections in different ways (overall, elective, emergency, intrapartum). This made synthesis and interpretation of findings across studies difficult. A unified system for classifying and reporting caesarean sections would be useful.

Taxonomy of caesarean section interventions

- Given the broad range of interventions intended to reduce caesarean sections (targeting women, community, public, healthcare professionals, healthcare organisations, facilities and systems), there is a need to develop a comprehensive typology of these interventions. This would aid identification, categorisation, comparison and synthesis in systematic reviews and related research.

Reporting interventions

- Studies should fully describe components of interventions (including standard care) to help implementation and replication. Use of the Template for Intervention Description and Replication (TIDieR) checklist is recommended (Hoffmann 2014).

\section{APPENDICES}

\section{Appendix 1. Search strategies (March 2018)}

\section{MEDLINE (OVID)}

Ovid MEDLINE(R) Epub Ahead of Print, In-Process \& Other Non-Indexed Citations, Ovid MEDLINE(R) Daily, Ovid MEDLINE and Versions(R) $<1946$ to 7 March 2018>

\begin{tabular}{lll}
\hline No. & Search terms & Results \\
\hline 1 & exp cesarean section/ & 40707 \\
\hline 2 & $\begin{array}{l}\text { ((caesarean or cesarean) adj2 (section? or birth? or deliver or } \\
\text { surgery)).ti,ab,kf. }\end{array}$ & 51101 \\
\hline 3 & c-section?.ti,ab,kf. & 1033 \\
\hline 4 & natural childbirth/ & 2330 \\
\hline
\end{tabular}




\begin{tabular}{|c|c|c|}
\hline 6 & ((operative or surgical) adj (birth* or deliver*)).ti,ab,kf. & 1790 \\
\hline 7 & (unnecessary cesarean* or unnecessary caesarean*).ti,ab,kf. & 136 \\
\hline 8 & or/1-7 & 67346 \\
\hline 9 & patient education as topic/ & 78996 \\
\hline 10 & decision making/ & 82374 \\
\hline 11 & exp clinical audit/ & 21032 \\
\hline 12 & exp education, professional/ & 273591 \\
\hline 13 & ((caesarean or cesarean) adj5 rate?).ti,ab,kf. & 6689 \\
\hline 14 & CS rate?.ti,ab,kf. & 405 \\
\hline 15 & (decision adj2 (aid? or tool?)).ti,ab,kf. & 7433 \\
\hline 16 & (audit? or feedback or fed back).ti,ab,kf. & 145940 \\
\hline 17 & opinion leader?.ti,ab,kf. & 1182 \\
\hline 18 & second opinion?.ti,ab,kf. & 1782 \\
\hline 19 & $\begin{array}{l}\left(\left(\text { midwife }^{\star} \text { or midwive }\right.\right. \\
\left.\left.\text { ag }^{\star}\right)\right) \text { adj } \mathrm{ti}, \mathrm{ab}, \mathrm{kf} \text { (led or lead }\end{array}$ & 848 \\
\hline
\end{tabular}

\begin{tabular}{|c|c|c|}
\hline 20 & 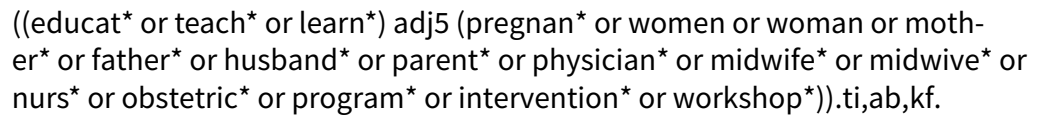 & 175663 \\
\hline 21 & $\begin{array}{l}\text { ((antenatal or birth* or childbirth) adj (program* or lesson* or class* or edu- } \\
\left.\left.\text { cat }^{\star}\right)\right) . t i, a b, k f .\end{array}$ & 1380 \\
\hline 22 & psychoeducation.ti,ab,kf. & 2188 \\
\hline 23 & or/9-22 & 704026 \\
\hline 24 & 8 and 23 & 8934 \\
\hline 25 & randomized controlled trial.pt. & 455307 \\
\hline 26 & controlled clinical trial.pt. & 92216 \\
\hline 27 & multicenter study.pt. & 229741 \\
\hline 28 & pragmatic clinical trial.pt. & 690 \\
\hline 29 & (randomis* or randomiz* or randomly).ti,ab. & 758637 \\
\hline 30 & groups.ab. & 1769815 \\
\hline
\end{tabular}


(Continued)

31 32 (trial or multicenter or multi center or multicentre or multi centre).ti.

211228

8329902

(intervention? or effect? or impact? or controlled or control group? or (before adj5 after) or (pre adj5 post) or ((pretest or pre test) and (posttest or post test)) or quasiexperiment ${ }^{\star}$ or quasi experiment ${ }^{\star}$ or pseudo experiment ${ }^{\star}$ or pseudoexperiment ${ }^{\star}$ or evaluat ${ }^{\star}$ or time series or time point? or repeated measur $\left.{ }^{\star}\right)$.ti,ab.

\begin{tabular}{|c|c|c|}
\hline 33 & non-randomized controlled trials as topic/ & 293 \\
\hline 34 & interrupted time series analysis/ & 388 \\
\hline 35 & controlled before-after studies/ & 305 \\
\hline 36 & or/25-35 & 9300000 \\
\hline 37 & exp animals/ & 21359264 \\
\hline 38 & humans/ & 16926842 \\
\hline 39 & 37 not (37 and 38) & 4432422 \\
\hline 40 & review.pt. & 2351394 \\
\hline 41 & meta analysis.pt. & 85606 \\
\hline 42 & news.pt. & 186291 \\
\hline 43 & comment.pt. & 707682 \\
\hline 44 & editorial.pt. & 452023 \\
\hline 45 & cochrane database of systematic reviews.jn. & 13470 \\
\hline 46 & comment on.cm. & 707679 \\
\hline 47 & (systematic review or literature review).ti. & 107442 \\
\hline 48 & or/39-47 & 7827358 \\
\hline 49 & 36 not 48 & 6500762 \\
\hline 50 & 24 and 49 & 4681 \\
\hline 51 & $\begin{array}{l}\left(2010^{\star} \text { or } 2011^{\star} \text { or } 2012^{\star} \text { or } 2013^{\star} \text { or } 2014^{\star} \text { or } 2015^{\star} \text { or } 2016^{\star} \text { or } 2017^{\star} \text { or }\right. \\
\left.2018^{\star}\right) . d t, d p, e d, e p, y r .\end{array}$ & 9397266 \\
\hline 52 & 50 and 51 & 2247 \\
\hline
\end{tabular}

\section{Embase (OVID)}

Embase $<1974$ to 2018 March 7> 


\begin{tabular}{|c|c|c|}
\hline No. & Search terms & Results \\
\hline 1 & exp *cesarean section/ & 27445 \\
\hline 2 & $\begin{array}{l}\text { ((caesarean or cesarean) adj2 (section? or birth? or deliver* or } \\
\text { surgery)).ti,ab,kw. }\end{array}$ & 69574 \\
\hline 3 & c-section?.ti,ab,kw. & 2676 \\
\hline 4 & *natural childbirth/ & 1481 \\
\hline 5 & (natural adj (birth or childbirth)).ti,ab,kw. & 585 \\
\hline 6 & (unnecessary cesarean* or unnecessary caesarean*).ti,ab,kw. & 171 \\
\hline 7 & ((operative or surgical) adj (birth or deliver)).ti,ab,kw. & 2589 \\
\hline 8 & or/1-7 & 78200 \\
\hline 9 & ${ }^{*}$ patient education/ & 27239 \\
\hline 10 & *shared decision making/ & 783 \\
\hline 11 & ${ }^{\star}$ patient decision making/ & 1805 \\
\hline 12 & exp *decision support system/ & 9529 \\
\hline 13 & ${ }^{\star}$ clinical audit/ & 516 \\
\hline 14 & *vocational education/ & 4615 \\
\hline 15 & ${ }^{\star}$ continuing education/ & 8940 \\
\hline 16 & *education program/ & 9465 \\
\hline 17 & ${ }^{*}$ in service training/ & 6606 \\
\hline 18 & ${ }^{*}$ medical education/ & 104893 \\
\hline 19 & ${ }^{\star}$ childbirth education/ & 118 \\
\hline 20 & ((caesarean or cesarean) adj5 rate?).ti,ab,kw. & 9705 \\
\hline 21 & CS rate?.ti,ab,kw. & 806 \\
\hline 22 & (decision adj2 (aid? or tool?)).ti,ab,kw. & 10568 \\
\hline 23 & (audit? or feedback or fed back).ti,ab,kw. & 206003 \\
\hline 24 & opinion leader?.ti,ab,kw. & 1605 \\
\hline 25 & second opinion?.ti,ab,kw. & 2822 \\
\hline 26 & 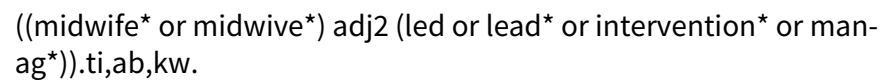 & 1036 \\
\hline
\end{tabular}



er ${ }^{\star}$ or father ${ }^{\star}$ or husband ${ }^{\star}$ or parent ${ }^{\star}$ or physician ${ }^{\star}$ or midwife ${ }^{\star}$ or midwive* or nurs $^{\star}$ or obstetric ${ }^{\star}$ or program* or intervention ${ }^{\star}$ or workshop*)).ti,ab,kw.

28 ((antenatal or birth* or childbirth) adj (program ${ }^{\star}$ or lesson ${ }^{\star}$ or class ${ }^{\star}$ or edu-
cat $\left.\left.^{\star}\right)\right) . t i, a b, k w$.

\begin{tabular}{|c|c|c|}
\hline 29 & psychoeducation.ti,ab,kw. & 3573 \\
\hline 30 & or/9-29 & 580458 \\
\hline 31 & 8 and 30 & 12104 \\
\hline 32 & randomized controlled trial/ & 490387 \\
\hline 33 & controlled clinical trial/ & 455867 \\
\hline 34 & quasi experimental study/ & 4309 \\
\hline 35 & pretest posttest control group design/ & 330 \\
\hline 36 & time series analysis/ & 20321 \\
\hline 37 & experimental design/ & 15194 \\
\hline 38 & multicenter study/ & 177380 \\
\hline 39 & (randomis* or randomiz* or randomly).ti,ab. & 1044802 \\
\hline 40 & groups.ab. & 2397974 \\
\hline 41 & (trial or multicentre or multicenter or multi centre or multi center).ti. & 293432 \\
\hline 42 & $\begin{array}{l}\text { (intervention? or effect? or impact? or controlled or control group? or (be- } \\
\text { fore adj5 after) or (pre adj5 post) or ((pretest or pre test) and (posttest or post } \\
\text { test)) or quasiexperiment }{ }^{\star} \text { or quasi experiment }{ }^{\star} \text { or pseudo experiment }{ }^{\star} \text { or } \\
\text { pseudoexperiment } \text { or }^{\star} \text { evaluat }^{\star} \text { or time series or time point? or repeated mea- } \\
\left.\text { sur }{ }^{\star}\right) \text {.ti,ab. }\end{array}$ & 10604676 \\
\hline 43 & or/32-42 & 11829255 \\
\hline 44 & (systematic review or literature review).ti. & 126655 \\
\hline 45 & "cochrane database of systematic reviews".jn. & 11656 \\
\hline 46 & $\begin{array}{l}\text { exp animals/ or exp invertebrate/ or animal experiment/ or animal model/or } \\
\text { animal tissue/ or animal cell/ or nonhuman/ }\end{array}$ & 25647687 \\
\hline 47 & human/ or normal human/ or human cell/ & 19376788 \\
\hline 48 & 46 not (46 and 47$)$ & 6318930 \\
\hline 49 & 44 or 45 or 48 & 6456024 \\
\hline 50 & 43 not 49 & 9017948 \\
\hline
\end{tabular}


(Continued)

5131 and $50 \quad 7507$

The Cochrane Library (Wiley)

\begin{tabular}{|c|c|c|}
\hline No. & Search terms & Results \\
\hline \#1 & [mh "cesarean section"] & 2950 \\
\hline \#2 & ((caesarean or cesarean) near/2 (section? or birth? or deliver ${ }^{\star}$ or surgery)):ti,ab & 3174 \\
\hline \#3 & c-section?:ti,ab & 12 \\
\hline \#4 & [mh "natural childbirth"] & 34 \\
\hline \#5 & (natural next (birth or childbirth)):ti,ab & 23 \\
\hline \#6 & ((operative or surgical) next (birth or deliver $\left.\left.{ }^{\star}\right)\right): t i, a b$ & 249 \\
\hline$\# 7$ & (unnecessary next cesarean* or unnecessary next caesarean*):ti,ab & 12 \\
\hline$\# 8$ & $\{$ or \#1-\#7\} & 5068 \\
\hline$\# 9$ & [mh "patient education as topic"] & 8530 \\
\hline$\# 10$ & [mh "decision making"] & 3940 \\
\hline \#11 & [mh "clinical audit"] & 356 \\
\hline$\# 12$ & [mh "education, professional"] & 4356 \\
\hline$\# 13$ & ((caesarean or cesarean) near/5 rate?):ti,ab & 397 \\
\hline$\# 14$ & (CS next rate?):ti,ab & 19 \\
\hline \#15 & (decision near/2 (aid? or tool?)):ti,ab & 455 \\
\hline \#16 & (audit? or feedback or fed back):ti,ab & 8865 \\
\hline$\# 17$ & (opinion next leader?):ti,ab & 125 \\
\hline$\# 18$ & (second next opinion?):ti,ab & 11 \\
\hline \#19 & $\left(\left(\right.\right.$ midwife $^{\star}$ or midwive $\left.{ }^{\star}\right)$ near/2 (led or lead ${ }^{\star}$ or intervention* ${ }^{\star}$ or manag $\left.\left.{ }^{\star}\right)\right):$ ti,ab & 131 \\
\hline$\# 20$ & 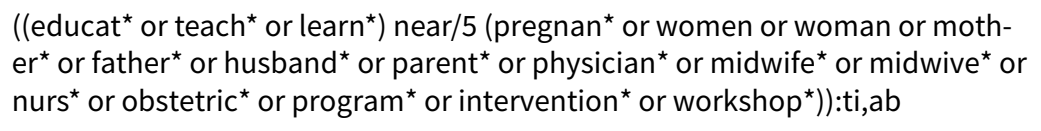 & 19774 \\
\hline \#21 & $\begin{array}{l}((\text { antenatal or birth* or childbirth) next (program* or lesson* or class* or edu- } \\
\left.\text { cat }^{\star}\right) \text { ):ti,ab }\end{array}$ & 133 \\
\hline
\end{tabular}




\begin{tabular}{lll}
$\# 22$ & psychoeducation:ti,ab & 906 \\
\hline$\# 23$ & $\{$ or \#9-\#22 & 40779 \\
\hline$\# 24$ & $\# 8$ and \#23 & 420 \\
\hline$\# 25$ & $\# 8$ and \#23 Publication Year from 2014 to 2018 \\
\hline
\end{tabular}

\section{Cinahl (EBSCO)}

\begin{tabular}{|c|c|c|}
\hline No. & Search terms & Results \\
\hline S1 & (MH "Cesarean Section+") & 9,860 \\
\hline S2 & ((caesarean or cesarean) N2 (section? or birth? or deliver ${ }^{\star}$ or surgery)) & 5,413 \\
\hline S3 & c-section & 334 \\
\hline S4 & (natural No (birth or childbirth)) & 212 \\
\hline S5 & ((operative or surgical) NO (birth* or deliver $)$ ) & 378 \\
\hline S6 & (unnecessary cesarean ${ }^{\star}$ or unnecessary caesarean ${ }^{\star}$ ) & 53 \\
\hline S7 & (MH "Prepared Childbirth") & 631 \\
\hline S8 & S1 OR S2 OR S3 OR S4 OR S5 OR S6 OR S7 & 12,977 \\
\hline S9 & (MH "Patient Education") & 44,761 \\
\hline S10 & (MH "Childbirth Education") & 1,934 \\
\hline S11 & (MH "Childbirth Educators") & 420 \\
\hline $\mathrm{S} 12$ & (MH "Decision Making") & 24,928 \\
\hline S13 & (MH "Decision Making, Patient") & 11,466 \\
\hline S14 & (MH "Decision Support Techniques") & 2,550 \\
\hline S15 & (MH "Audit") & 10,726 \\
\hline S16 & (MH "Psychoeducation") & 1,990 \\
\hline S17 & (MH "Education, Clinical") & 9,012 \\
\hline S18 & MH "Education, Continuing") & 7,685 \\
\hline S19 & ((caesarean or cesarean) N5 rate?) & 1,090 \\
\hline S20 & CS rate? & 97 \\
\hline
\end{tabular}


(Continued)

\begin{tabular}{|c|c|c|}
\hline S21 & (decision N2 (aid? or tool?)) & 1,043 \\
\hline S22 & (audit? or feedback or fed back) & 21,596 \\
\hline S23 & (opinion leader?) & 343 \\
\hline S24 & (second opinion?) & 141 \\
\hline S25 & $\left(\left(\right.\right.$ midwife $^{\star}$ or midwive $\left.{ }^{\star}\right)$ N2 (led or lead ${ }^{\star}$ or intervention ${ }^{\star}$ or manag $\left.\left.^{\star}\right)\right)$ & 1,170 \\
\hline S26 & 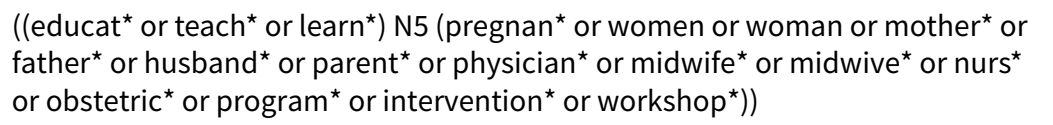 & 159,310 \\
\hline S27 & $\begin{array}{l}\text { ((antenatal or birth* or childbirth) N0 (program or lesson* or class* or edu- } \\
\left.\left.\text { cat }^{\star}\right)\right)\end{array}$ & 2,897 \\
\hline S28 & psychoeducation & 2,356 \\
\hline S29 & $\begin{array}{l}\text { S9 OR S } 10 \text { OR S11 OR S } 12 \text { OR S } 13 \text { OR S } 14 \text { OR S15 OR S16 OR S17 OR S18 OR S19 } \\
\text { OR S20 OR S21 OR S22 OR S23 OR S24 OR S25 OR S26 OR S27 OR S28 }\end{array}$ & 274,020 \\
\hline S30 & S8 AND S29 & 2,191 \\
\hline S31 & PT randomized controlled trial & 42,986 \\
\hline S32 & PT clinical trial & 55,844 \\
\hline S33 & PT research & $1,186,187$ \\
\hline S34 & (MH "Randomized Controlled Trials") & 40,140 \\
\hline S35 & (MH "Clinical Trials") & 92,783 \\
\hline S36 & (MH "Intervention Trials") & 6,880 \\
\hline S37 & (MH "Nonrandomized Trials") & 253 \\
\hline S38 & (MH "Experimental Studies") & 17,663 \\
\hline S39 & (MH "Pretest-Posttest Design+") & 30,750 \\
\hline S40 & (MH "Quasi-Experimental Studies+") & 10,272 \\
\hline S41 & (MH "Multicenter Studies") & 34,631 \\
\hline S42 & (MH "Health Services Research") & 8,010 \\
\hline S43 & $\begin{array}{l}\mathrm{TI} \text { ( randomis }{ }^{*} \text { or randomiz* or randomly) OR AB ( randomis* or randomiz }{ }^{\star} \text { or } \\
\text { randomly) }\end{array}$ & 140,270 \\
\hline S44 & 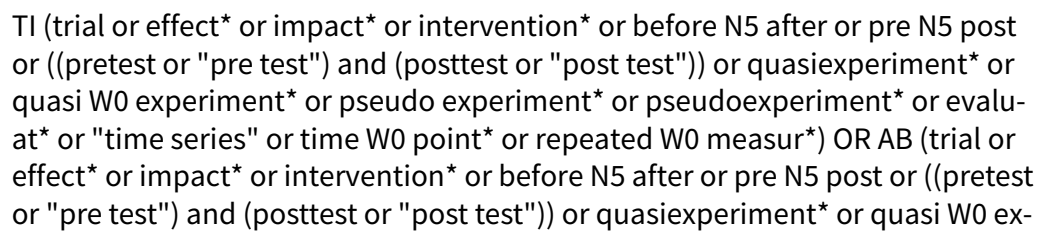 & 961,623 \\
\hline
\end{tabular}


periment ${ }^{\star}$ or pseudo experiment ${ }^{\star}$ or pseudoexperiment ${ }^{\star}$ or evaluat ${ }^{\star}$ or "time series" or time Wo point ${ }^{\star}$ or repeated W0 measur*)

\begin{tabular}{llc}
\hline S45 & S31 OR S32 OR S33 OR S34 OR S35 OR S36 OR S37 OR S38 OR S39 OR S40 OR & $1,568,152$ \\
\hline S41 OR S42 OR S43 OR S44 & 1,426 \\
\hline S47 & S30 AND S45 & 418 \\
\hline S48 & S46 Limiters - Exclude MEDLINE records & 239 \\
\hline
\end{tabular}

\section{ClinicalTrials.gov}

$\begin{array}{ll}\text { Search terms } & \text { Results }\end{array}$

"caesarean section" OR "caesarean birth" OR "caesarean delivery" OR "cesarean section” OR "ce- 229 sarean birth" OR "cesarean delivery"

Interventional Studies

WHO International Clinical Trials Registry Platform (ICTRP)

\begin{tabular}{ll}
\hline Search terms & Results \\
\hline caesarean or cesarean & 1972 \\
\hline
\end{tabular}

\section{Appendix 2. Search strategies (August 2014)}

\section{MEDLINE (OVID) (In-Process \& Other Non-Indexed Citations) (search date: 6 August 2014)}

1 exp Cesarean Section/ (0)

2 ((caesarean or cesarean) adj2 (section? or birth? or deliver\$)).ti,ab. (3115)

3 c-section?.ti,ab. (60)

4 or/1-3 (3151)

5 exp *education, continuing/ or * pamphlets/ or *advance directives/ or * reminder systems/ or * feedback/ (0)

6 (education\$ adj2 (program\$ or intervention? or meeting? or session? or strateg\$ or workshop? or visit?)).tw. (3881)

7 (leaflet? or booklet? or poster?).tw. (2015)

8 ((written or printed or oral) adj information).tw. (103)

9 (information\$ adj2 campaign).tw. (16)

10 (education\$ adj1 (method? or material?)).tw. (406)

11 (outreach or facilitator? or "academic detailing" or "consensus conference?" or algorithm? feedback or marketing).tw.

(3426)

12 ((opinion or education\$ or influential) adj1 leader?).tw. (98)

13 ((reminder? or recall) adj2 system?).ti,ab. (61)

14 (prompter? or prompting).tw. (485)

15 (chart adj2 review\$).ti,ab. (2255)

16 ((effect? or impact or record? or chart?) adj2 audit).tw. (79)

17 or/5-16 (12411)

18 exp *reimbursement mechanisms/ or *capitation fee/ or *"deductibles and coinsurance"/ or *hospital charges/ or ${ }^{*}$ Medicaid/ or * medicare/ (0) 
19 fee for service.tw. (195)

20 cost shar\$.tw. (88)

21 (copayment? or co payment?).tw. (104)

22 (prepay\$ or prepaid or prospective payment?).tw. (91)

23 (formular? or fundhold? or "blue cross").tw. (305)

24 or/18-23 (740)

25 * nurse clinicians/ or *nurse midwives/ or * nurse practitioners/ or * pharmacists/ or * patient care team/ or exp* patient care

planning/ or exp *ambulatory care facilities/ or *ambulatory care/ (1)

26 (nurse adj (rehabilitator? or clinician? or practitioner? or midwi\$)).tw. (671)

27 clinical pharmacist?.tw. (179)

28 paramedic?.tw. (226)

29 (team? adj2 (care or treatment or assessment or consultation)).tw. (905)

30 (care adj2 (coordinat\$ or program\$ or continuity)).tw. (1542)

31 (case adj management).tw. (453)

32 or/25-31 (3802)

33 *home care services/ or *hospices/ or *nursing homes/ or * office visits/ or *house calls/ or *day care/ or *aftercare/ or

${ }^{*}$ community health nursing/ or *medical records/ or * medical records systems, computerized/ or * peer review/ or *utilization review/ or exp *health services misuse/ (0)

34 (chang\$ adj1 location?).tw. (45)

35 domiciliary.tw. (87)

36 (home adj1 treat\$).tw. (86)

37 day surgery.tw. (97)

38 (information adj2 (management or system?)).tw. (2370)

39 or/33-38 (2682)

40 * physician's practice patterns/ or * process assessment/ or * program evaluation/ or *length of stay/ or exp * "Referral and Consultation"/ or "consultation"/ or *drug therapy, computer assisted/ or *medical history taking/ or *telephone/ or *health maintenance organizations/ (0)

41 quality assurance.tw. (1140)

42 (early adj1 discharg\$).tw. (140)

43 discharge planning.tw. (94)

44 offset.tw. (2484)

45 triage.tw. (831)

46 near patient testing.tw. (7)

47 (physician patient adj (interaction? or relationship?)).tw. (103)

48 managed care.tw. (325)

49 (hospital? adj1 merg\$).tw. (7)

50 or/40-49 (5108)

51 ((standard or usual or routine or regular or traditional or conventional or pattern) adj2 care).tw. (4458)

52 (program\$ adj2 (reduc\$ or increas\$ or decreas\$ or chang\$ or improv\$ or modify $\$$ or monitor $\$$ or care)).tw. (3703)

53 (computer\$ adj2 (dosage or dosing or diagnosis or therapy or decision?)).tw. (266)

54 ((introduc\$ or impact or effect? or implement\$ or computer\$) adj2 protocol?).tw. (428)

55 ((effect or impact or introduc\$) adj2 (legislation or regulations or policy)).tw. (133)

56 or/51-55 (8846)

5717 or 24 or 32 or 39 or 50 (23890)

58 (intervention? or multiintervention? or multi-intervention? or postintervention? or post-intervention? or preintervention? or pre-intervention?).ti,ab. (49536)

59 (change or changing or evaluation or IMPROVE or IMPROVES or improvement? or improving).ti. (42422)

60 ((chang\$ or improv\$ or quality or evaluat\$) adj3 (care or healthcare or organi?ation\$ or practitioner? or practice)).ab. (9504)

61 implement\$.ti. (3663)

62 (multi-facet\$ or multifacet\$).ti,ab. (1402)

63 ((guideline? or pathway? or protocol?) adj3 (adhere\$ or concord\$ or uptake or up-take)).ti,ab. (702)

64 ((physician? or provider? or practitioner?) adj2 behavio\$).ti,ab. (211)

65 (collaborat\$ or teambased or team-based or interdisciplinar\$ or inter-disciplinar\$ or cross-disciplin\$).ti,ab. or team?.ti. (10943)

66 effectiveness.ti. or (effective adj2 practice).ti,ab. (4620)

67 Guideline adherence.hw. (2)

68 (financial or payment?).ti. (838)

69 evidence-based.ti,hw. (2041)

70 or/58-69 [INTERVENTION terms] (112958)

71 intervention?.ti. or (intervention? adj6 (clinician? or collaborat\$ or community or complex or DESIGN\$ or doctor? or educational or family doctor? or family physician? or family practitioner? or financial or GP or general practice? or hospital?

Non-clinical interventions for reducing unnecessary caesarean section (Review)

Copyright @ 2018 The Cochrane Collaboration. Published by John Wiley \& Sons, Ltd. 
or impact? or improv\$ or individuali?e? or individuali?ing or interdisciplin\$ or multicomponent or multi-component or multidisciplin\$ or multi-disciplin\$ or multifacet\$ or multi-facet\$ or multimodal\$ or multi-modal\$ or personali?e? or personali?ing or pharmacies or pharmacist? or pharmacy or physician? or practitioner? or prescrib\$ or prescription? or primary care or professional\$ or provider? or regulatory or regulatory or tailor\$ or target\$ or team $\$$ or usual care)).ab. (16931)

72 (pre-intervention? or preintervention? or "pre intervention?" or post-intervention? or postintervention? or "post intervention?").ti,ab. [added 2.4] (1427)

73 (hospital\$ or patient?).hw. and (study or studies or care or health\$ or practitioner? or provider? or physician? or nurse? or nursing or doctor?).ti,hw. (2)

74 demonstration project?.ti,ab. (88)

75 (pre-post or "pre test\$" or pretest\$ or posttest\$ or "post test\$" or (pre adj5 post)).ti,ab. (7453)

76 (pre-workshop or post-workshop or (before adj3 workshop) or (after adj3 workshop)).ti,ab. (78)

77 trial.ti. or ((study adj3 aim?) or "our study").ab. (66512)

78 (before adj10 (after or during)).ti,ab. (22446)

79 ("quasi-experiment\$" or quasiexperiment\$ or "quasi random\$" or quasirandom\$ or "quasi control\$" or quasicontrol\$ or ((quasi\$ or experimental) adj3 (method\$ or study or trial or design\$))).ti,ab,hw. (11324)

80 ("time series" adj2 interrupt\$).ti,ab,hw. (121)

81 (time points adj3 (over or multiple or three or four or five or six or seven or eight or nine or ten or eleven or twelve or

month\$ or hour? or day? or "more than")).ab. (894)

82 pilot.ti. (4001)

83 Pilot projects/ (0)

84 (clinical trial or controlled clinical trial or multicenter study).pt. (489)

85 (multicentre or multicenter or multi-centre or multi-center).ti. (2155)

86 random\$.ti,ab. or controlled.ti. (74207)

87 (control adj3 (area or cohort? or compare? or condition or design or group? or intervention? or participant? or study)).ab. not (controlled clinical trial or randomized controlled trial).pt. (38069)

88 (control year? or experimental year? or (control period? or experimental period?)).ti,ab. [Added May 30-2013] (718)

89 evaluation studies as topic/ or prospective studies/ or retrospective studies/ [Added Jan 2013] (4)

90 (utili?ation or programme or programmes).ti. [Added Jan 2013] (3980)

91 (during adj5 period).ti,ab. [Added Jan 2013] (19076)

92 ((strategy or strategies) adj2 (improv\$ or education\$)).ti,ab. [Added Jan 2013] (2141)

93 (purpose adj3 study).ab. (19505)

94 "comment on".cm. or review.pt. or (review not "peer review\$").ti. or randomized controlled trial.pt. [Changed Jan 2013]

(83817)

95 (rat or rats or cow or cows or chicken? or horse or horses or mice or mouse or bovine or animal?).ti,hw. or veterinar\$.ti, ab,hw. [Edited May 2013] (51956)

96 exp animals/ not humans.sh. (5)

97 (or/71-93) not (or/94-96) [EPOC Methods Filter 2.6-added Evaluation Studies line forward--Jan 20130 Medline] (204923)

98 (randomized controlled trial or controlled clinical trial).pt. or randomized.ab. or placebo.ab. or clinical trials as topic.sh. or randomly.ab. or trial.ti. (49946)

99 exp animals/ not humans.sh. (5)

10098 not 99 [Cochrane RCT Filter 6.4.d Sens/Precision Maximizing] (49946)

1014 and (57 or 70) and 97 [EPOC Results before date limits] (195)

1024 and (57 or 70) and 100 [RCT Results before date limits] (68)

103 (201008\$ or $2011 \$$ or $2012 \$$ or $2013 \$$ or $2014 \$)$.em,dp,yr. (1269997)

104101 and 103 [EPOC 2010-2014] (178)

105102 and 103 [RCT 2010-2014] (61)

\section{Embase (OVID) (search date: 6 August 2014)}

1 exp Cesarean Section/ (67446)

2 ((caesarean or cesarean) adj2 (section? or birth? or deliver\$)).ti,ab. (56175)

3 c-section?.ti,ab. (1525)

4 or/1-3 (78835)

5 continuing education/ or professional development/ or reminder system/ or clinical education/ or in service training/ [EM] (56167)

6 (education\$ adj2 (program\$ or intervention? or meeting? or session? or strateg\$ or workshop? or visit?)).tw. (58016)

7 (leaflet? or booklet? or poster?).tw. (36092)

8 ((written or printed or oral) adj information).tw. (2293)

9 (information\$ adj2 campaign).tw. (484)

10 (education\$ adj1 (method? or material?)).tw. (7609)

11 outreach.tw. (10141) 
12 ((opinion or education\$ or influential) adj1 leader?).tw. (1247)

13 facilitator?.tw. (15931)

14 academic detailing.tw. (443)

15 consensus conference?.tw. (5452)

16 ((reminder? or recall) adj2 system?).ti,ab. (1079)

17 (prompter? or prompting).tw. (6695)

18 algorithm?.tw. (155893)

19 feedback.tw. (101865)

20 (chart adj2 review\$).ti,ab. (38759)

21 ((effect? or impact or record? or chart?) adj2 audit).tw. (1336)

22 marketing.tw. (22911)

23 or/5-22 (501449)

24 * reimbursement/ or capitation fee/ or hospital charge/ or *"cost"/ or medicare/ or medicaid/ [EM] (95147)

25 fee for service.tw. (4223)

26 cost shar\$.tw. (1425)

27 (copayment? or co payment?).tw. (1772)

28 (prepay\$ or prepaid or prospective payment?).tw. (4843)

29 formular?.tw. (4781)

30 fundhold?.tw. (1)

31 blue cross.tw. (1403)

32 or/24-31 (107608)

33 advanced practice nurse/ or clinical nurse specialist/ or nurse midwife/ or nurse practitioner/ or pharmacist/ or * patient care planning/ or *ambulatory care/ or *ambulatory monitoring/ [EM] (95763)

34 (nurse adj (rehabilitator? or clinician? or practitioner? or midwi\$)).tw. (12691)

35 clinical pharmacist?.tw. (2904)

36 paramedic?.tw. (4518)

37 (team? adj2 (care or treatment or assessment or consultation)).tw. (14467)

38 (care adj2 (coordinat\$ or program\$ or continuity)).tw. (24786)

39 (case adj management).tw. (8860)

40 or/33-39 (148821)

41 exp *home care/ or hospice/ or hospice care/ or *nursing home/ or aftercare/ or * community health nursing/ or medical record/ or *health care utilization/ or * utilization review"/ [EM] (217481)

42 (chang\$ adj1 location?).tw. (455)

43 domiciliary.tw. (3296)

44 (home adj1 treat\$).tw. (2100)

45 day surgery.tw. (2940)

46 (information adj2 (management or system?)).tw. (32814)

47 or/41-46 (254076)

48 * program development/ or *health care quality/ or *"length of stay"/ or patient referral/ or anamnesis/ or computer assisted drug therapy/ or health maintenance organization/ or *telemedicine/ or teleconsultation/ or telemonitoring/ [EM] (275665)

49 quality assurance.tw. (24832)

50 (early adj1 discharg\$).tw. (3027)

51 discharge planning.tw. (2691)

52 offset.tw. (21988)

53 triage.tw. (13606)

54 near patient testing.tw. (253)

55 (physician patient adj (interaction? or relationship?)).tw. (2236)

56 managed care.tw. (18676)

57 (hospital? adj1 merg\$).tw. (416)

58 or/48-57 (352044)

59 ((standard or usual or routine or regular or traditional or conventional or pattern) adj2 care).tw. (56059)

60 (program $\$$ adj2 (reduc $\$$ or increas $\$$ or decreas $\$$ or chang $\$$ or improv\$ or modify $\$$ or monitor $\$$ or care)).tw. (52493)

61 (computer\$ adj2 (dosage or dosing or diagnosis or therapy or decision?)).tw. (4815)

62 ((introduc\$ or impact or effect? or implement\$ or computer\$) adj2 protocol?).tw. (3946)

63 ((effect or impact or introduc\$) adj2 (legislation or regulations or policy)).tw. (2021)

64 or/59-63 (117274)

6523 or 32 or 40 or 47 or 58 or 64 (1328796)

664 and 65 (5198)

67 controlled clinical trial/ or controlled study/ or randomized controlled trial/ [EM] (4454983)

68 randomi?ed.ti. or ((random\$ or control) adj3 (group? or cohort? or patient? or hospital\$ or department?)).ab. or (controlled adj2 (study or trial)).ti. (727293)

69 (multicenter and (study or trial)).ti. (22099)

Non-clinical interventions for reducing unnecessary caesarean section (Review) Copyright @ 2018 The Cochrane Collaboration. Published by John Wiley \& Sons, Ltd. 
70 (random sampl\$ or random digit\$ or random effect\$ or random survey or random regression).ti,ab. not randomized controlled trial/ [Per BMJ Clinical Evidence filter] (58004)

71 (exp animals/ or exp invertebrate/ or animal experiment/ or animal model/ or animal tissue/ or animal cell/ or nonhuman/) and (human/ or normal human/ or human cell/) (15174084)

72 (exp animals/ or exp invertebrate/ or animal experiment/ or animal model/ or animal tissue/ or animal cell/ or nonhuman/) not 71 (5874509)

73 (or/67-69) not (or/70,72) [RCT Filter for EMBASE] (3041624)

74 intervention?.ti. or (intervention? adj6 (clinician? or collaborat\$ or community or complex or DESIGN\$ or doctor? or educational or family doctor? or family physician? or family practitioner? or financial or GP or general practice? or hospital? or impact? or improv\$ or individuali?e? or individuali?ing or interdisciplin\$ or multicomponent or multi-component or multidisciplin\$ or multi-disciplin\$ or multifacet\$ or multi-facet\$ or multimodal\$ or multi-modal\$ or personali?e? or personali?ing or pharmacies or pharmacist? or pharmacy or physician? or practitioner? or prescrib\$ or prescription? or primary care or professional\$ or provider? or regulatory or regulatory or tailor $\$$ or target $\$$ or team $\$$ or usual care)).ab. (215196)

75 (pre-intervention? or preintervention? or "pre intervention?" or post-intervention? or postintervention? or "post intervention?").ti,ab. [added 2.4] (14286)

76 (hospital\$ or patient?).hw. and (study or studies or care or health\$ or practitioner? or provider? or physician? or nurse? or nursing or doctor?).ti,hw. (1771656)

77 demonstration project?.ti,ab. (2410)

78 (pre-post or "pre test\$" or pretest\$ or posttest\$ or "post test\$" or (pre adj5 post)).ti,ab. (103001)

79 (pre-workshop or post-workshop or (before adj3 workshop) or (after adj3 workshop)).ti,ab. (910)

80 trial.ti. or ((study adj3 aim?) or "our study").ab. (905869)

81 (before adj10 (after or during)).ti,ab. (485407)

82 (time points adj3 (over or multiple or three or four or five or six or seven or eight or nine or ten or eleven or twelve or

month\$ or hour? or day? or "more than")).ab. (12888)

83 pilot.ti. or (pilot adj (project? or study or trial)).ab. (93525)

84 (multicentre or multicenter or multi-centre or multi-center).ti. (41370)

85 random\$.ti,ab. or controlled.ti. (969384)

86 (control adj3 (area or cohort? or compare? or condition or design or group? or intervention? or participant? or study)).ab. (643628)

87 ((evaluation or prospective or retrospective) adj study).ti,ab. [Added Jan 2013] (244113)

88 (utili?ation or programme or programmes).ti. [Added Jan 2013] (73041)

89 (during adj5 period).ti,ab. [Added Jan 2013] (416162)

90 ((strategy or strategies) adj2 (improv\$ or education\$)).ti,ab. [Added Jan 2013] (23681)

91 *experimental design/ or * pilot study/ or quasi experimental study/ (8891)

92 ("quasi-experiment\$" or quasiexperiment\$ or "quasi random\$" or quasirandom\$ or "quasi control\$" or quasicontrol\$ or ((quasi\$ or experimental) adj3 (method\$ or study or trial or design\$))).ti,ab. (129669)

93 ("time series" adj2 interrupt\$).ti,ab. (1214)

94 or/74-93 (4719795)

95 (rat or rats or cow or cows or chicken? or horse or horses or mice or mouse or bovine or animal?).ti. (1629462)

96 (exp animals/ or exp invertebrate/ or animal experiment/ or animal model/ or animal tissue/ or animal cell/ or nonhuman/) and (human/ or normal human/ or human cell/) (15174084)

97 (exp animals/ or exp invertebrate/ or animal experiment/ or animal model/ or animal tissue/ or animal cell/ or nonhuman/) not 96 (5874509)

9894 not (or/95,97) [EPOC Filter 2.5--Added Lines Jan. 2013] (4071232)

9966 and $73[\mathrm{RCT}](1058)$

10066 and 98 [EPOC] (2773)

10199 or 100 [ALL] (3024)

102 remove duplicates from 101 (2997)

103 limit 102 to $y r=" 2010$-Current" (1343)

\section{Cochrane Central Register of Controlled Trials (OVID) (search date: 6 August 2014)}

1 (cesarean? or caeserean? or c-section? or "abdominal birth\$" or "abdominal deliver\$").ti,hw,sh. (3610)

2 (reduc\$ or decreas\$ or lower\$ or intervention?).ti. (49575)

3 (reduc $\$$ or decreas\$ or lower\$ or intervention?).ab. (293801)

4 ((reduc\$ or decreas\$ or prevent\$ or lower\$ or intervention?) adj4 (cesarean\$ or caesarean\$ or c-section\$ or "abdominal deliver\$")).ab. (595)

5 ((increas\$ or escalat\$ or growing or rising) adj4 (cesarean\$ or caesarean\$ or c-section\$ or "abdominal deliver\$")).ab. (199)

61 and (or/2-3) (1686)

7 or/4-5 (753)

87 or $6(1939)$ 
9 limit 8 to $y r=" 2010$-Current" (517)

108 and new.uf. (86)

11 limit 1 to $y r=" 2010-2014 "(751)$

121 and NEW.uf. (127)

13 or/9-12 (771)

Cochrane Library; CDSR, DARE, (WILEY) (search date: 6 August 2014)

1. MeSH descriptor Cesarean Section explode all trees

2. (cesarean* or caeserean* or c-section* or "abdominal birth*" or "abdominal deliver*"):ti,ab,kw.

3. (reduc or decreas $^{\star}$ or lower ${ }^{\star}$ or intervention*):ti OR (reduc* or decreas* or lower ${ }^{\star}$ or intervention $\left.{ }^{\star}\right): a b$

4. reduc ${ }^{\star}$ near/4 (cesarean* or caesarean* or c-section ${ }^{\star}$ or "abdominal deliver*"):ab

5. decreas ${ }^{\star}$ near/4 (cesarean* or caesarean ${ }^{\star}$ or c-section* or "abdominal deliver ${ }^{\star} "$ ):ab

6. prevent $^{\star}$ near/4 (cesarean* or caesarean* or c-section* or "abdominal deliver" ${ }^{\star}$ ):ab

7. lower near/4 (cesarean* or caesarean* or c-section* or "abdominal deliver"):ab.

8. intervention* near/4 (cesarean ${ }^{\star}$ or caesarean ${ }^{\star}$ or c-section* or "abdominal deliver "):ab.

9. increas* near/4 (cesarean* or caesarean* or c-section* or "abdominal deliver $\left.{ }^{\star} "\right): a b$.

10. escalat* near/4 (cesarean* or caesarean* or c-section* or "abdominal deliver*"):ab.

11. growing near/4 (cesarean* or caesarean* or c-section* or "abdominal deliver*"):ab.

12. rising near/4 (cesarean* or caesarean* or c-section* or "abdominal deliver*"):ab.

13. ((\#1 or \#2) and \#3)

14. (\#4 or \#5 or \#6 or \#7 or \#8 or \#9 or \#10 or \#11 or \#12)

15. \#13 or \#14

16. \#15, from 2010 to 2014

CINAHL (Ebsco) (search date: 6 August 2014)

Limits: 2010-2014

(( (( (MW ( cesarean )) or ( $\mathrm{TI}$ ( c section* OR cesarean OR caesarean OR "abdominal deliver* )) or (AB ( c section* OR cesarean OR caesarean OR "abdominal deliver*"))) AND ((( TI ( reduc* OR lower OR rising OR decreas $\left.{ }^{\star}\right)$ OR AB (reduc* OR lower OR rising OR decreas* $)))))$ AND $\left(\left(\left(\left(\mathrm{TI}\right.\right.\right.\right.$ ( interrupt ${ }^{\star} \mathrm{N} 2$ series $\left.)\right)$ or (TI ( interrupt ${ }^{\star} \mathrm{N} 2$ series )) or (AB ( interrupt ${ }^{\star} \mathrm{N} 2$ series $)))$ OR ((TI ( randomized OR randomised OR control* OR trial* $))$ ) OR ((MW ( clinical trials )) or (MW ( random assignment OR Chi square test OR pretest posttest design ))) OR ((MW ( quasi experiment ${ }^{\star}$ OR quasiexperiment $\left.\left.{ }^{\star}\right)\right)$ or (TI ( quasi experiment ${ }^{\star}$ OR quasiexperiment $\left.{ }^{\star}\right)$ ) or ( $\mathrm{AB}$ ( quasi experiment ${ }^{\star}$ OR quasiexperiment $\left.\left.{ }^{\star}\right)\right)$ ) OR ((TI ( intervention OR interventions $))$ or $(\mathrm{AB}$ ( intervention OR interventions )) or (MW ( intervention OR interventions $)))))$ )

\section{Appendix 3. Search strategies (February 2017)}

\section{Database: Ovid MEDLINE(R) In-Process \& Other Non-Indexed Citations and Ovid MEDLINE(R) <1946 to 17 February>}

1 Health Facility Environment/ (4101)

2 environment?.ti,ab. (448054)

3 "Interior Design and Furnishings"/ (4251)

4 (Interior adj3 Design?).ti,ab. (194)

5 (furniture or furnishing\$).ti,ab. (2830)

6 floor\$.ti,ab. (35402)

7 Lighting/ (10904)

8 (light\$ or lighting).ti,ab. (544050)

9 Music/ (12033)

10 Odorants/ (15526)

11 (scent or smell or odor).ti,ab. (19660)

12 Temperature/ (215850)

13 (room adj3 temperature).ti,ab. (56103)

14 ((hospital or unit or ward or clinic or department\$ or organisat\$ or organizat\$) adj3 (goal\$ or target\$ or purpose or object\$)).ti,ab. (8257)

15 Organizational culture/ (14966)

16 (organi?ation\$ adj3 cultur\$).ti,ab. (3222)

17 (corporate culture? or workplace culture? or work culture? or organ?ation\$ ethos or organi?ation\$ climate?).ti,ab. (1087)

18 or/1-17 (1313524)

19 Cesarean Section/ (39364)

20 ((caesarean or cesarean) adj2 (section? or birth? or deliver\$)).ti,ab. (47343)

21 c-section?.ti,ab. (868)

22 or/19-21 (61302)

2318 and $22(1295)$ 


\section{Database: Embase <1974 to 201717 February>}

1 *health care facility/ (23887)

2 environment?.ti,ab. (535512)

31 and 2 (1435)

4 exp furniture/ (28200)

5 (Interior adj3 Design?).ti,ab. (221)

6 (furniture or furnishing\$).ti,ab. (3749)

7 floor\$.ti,ab. (48549)

8 Lighting/ (24299)

9 (light\$ or lighting).ti,ab. (595293)

10 Music/ (16527)

11 odor/ (29465)

12 (scent or smell or odor).ti,ab. (25163)

13 room temperature/ or air temperature/ or environmental temperature/ (65969)

14 (room adj3 temperature).ti,ab. (59353)

15 ((hospital or unit or ward or clinic or department\$ or organisat\$ or organizat\$) adj3 (goal\$ or target\$ or purpose or

object\$)).ti,ab. (15597)

16 (organi?ation\$ adj3 cultur\$).ti,ab. (3576)

17 (corporate culture? or workplace culture? or work culture? or organ?ation\$ ethos or organi?ation\$ climate?).ti,ab. (1242)

18 or/3-17 (844128)

19 *cesarean section/ (27961)

20 ((caesarean or cesarean) adj2 (section? or birth? or deliver\$)).ti,ab. (64076)

21 c-section?.ti,ab. (2282)

22 or/19-21 (69962)

2318 and $22(1500)$

WHO International Clinical Trials Registry Platform (ICTRP) (searched April 2017)

Search terms: "caesarean section OR caesarean birth OR caesarean delivery"

ClinicalTrials.gov (searched April 2017)

Search terms: "caesarean section OR caesarean birth OR caesarean delivery"

WHAT'S NEW

\begin{tabular}{lll}
\hline Date & Event & Description \\
\hline 8 March 2018 & $\begin{array}{l}\text { New citation required and conclusions } \\
\text { have changed }\end{array}$ & $\begin{array}{l}\text { We amended the conclusions to highlight the limitation of the } \\
\text { evidence examined. }\end{array}$ \\
\hline 8 March 2018 & New search has been performed & $\begin{array}{l}\text { We updated the searches in August 2014, February 2017 and } \\
\text { March 2018. We expanded the scope of the review and added 17 } \\
\text { new studies in this update. We implemented GRADE and created } \\
\text { 'Summary of findings' tables. We amended the author team. Two } \\
\text { studies (Jang 2011; Vankan 2015) identified in the March 2018 } \\
\text { searches are awaiting classification. }\end{array}$ \\
\hline
\end{tabular}

\section{H IST ORY}

Protocol first published: Issue 4, 2005

Review first published: Issue 6, 2011

\begin{tabular}{lll}
\hline Date & Event & Description \\
\hline 26 June 2009 & Amended & Converted to new review format. \\
\hline
\end{tabular}




\section{CONTRIBUTIONS OF AUTHORS}

Original review

- Protocol development (SK, PL, TL, RG)

- All the authors contributed to the conduct of the review and approved the final version

For this update

- Designing search strategies and undertaking searches (TR, IC, APB, NO)

- Study selection (IC, EM, SM, APB, NO, SY, JP, SA, MT)

- Data collection and study quality assessment (IC, ET, APB, NO, SM, JP, SA, MT)

- Synthesis and writing of review (IC, APB, NO)

- All authors commented on the draft review and approved the final version

\section{DECLARATIONS OF INTEREST}

Innie Chen: no known conflicts of interest

Newton Opiyo is an editor with Cochrane EPOC and member of the WHO CS Guideline Technical Working Group

Emma Tavender: no known conflicts of interest

Sameh Mortazhejri: no known conflicts of interest

Tamara Rader: no known conflicts of interest

Jennifer Petkovic: no known conflicts of interest

Sharlini Yogasingam: no known conflicts of interest

Monica Taljaard: no known conflicts of interest

Sugandha Agarwal: no known conflicts of interest

Malinee Laopaiboon: no known conflicts of interest

Jason Wasiak: no known conflicts of interest

Suthit Khunpradit: no known conflicts of interest

Pisake Lumbiganon: Member of the WHO CS Guideline Development Group (Co-chair)

Russell Gruen: no known conflicts of interest

Ana Pilar Betran: Member of the WHO Steering Group who managed the CS guideline development process

\section{SOURCES OF SUPPORT}

\section{Internal sources}

- Australian Satellite of the Cochrane EPOC Group, Monash University, Australia.

Tavender Emma

- Bruyère Research Institute, University of Ottawa, Canada.

Jennifer Petkovic

- Canadian Agency for Drugs and Technologies in Health (CADTH), Canada.

Tamara Rader

- Review Production and Quality Unit, Cochrane, UK.

Newton Opiyo

- Khon Kaen University, Thailand.

Malinee Laopaiboon

- Lamphun Hospital, Thailand.

Suthit Khunpradit

- Ottawa Hospital Research Institute, Canada.

Monica Taljaard, Sameh Mortazhejri, Sugandha Agarwal

- Nanyang Technological University, Singapore.

Russell L Gruen 
- University of Melbourne, Australia.

Jason Wasiak

- University of Ottawa, Canada.

Innie Chen

\section{External sources}

- UNDP-UNFPA-UNICEF-WHO-World Bank Special Programme of Research, Development and Research Training in Human Reproduction (HRP), Department of Reproductive Health and Research (RHR), World Health Organization, Switzerland.

Ana Pilar Betran (WHO employee, salary support)

\section{DIFFERENCES BETWEEN PROTOCOLANDREVIEW}

- We updated the eligible study designs to align with current Cochrane EPOC criteria.

- We amended study eligibility criteria as follows.

- To avoid duplication and substantial overlap with related reviews, we excluded studies of other related interventions assessed in related reviews: midwife-led continuity of care (Sandall 2016); continuous labour support (Bohren 2017); physical activity-based interventions (i-WIP 2017); alternative institutional birth environment (Hodnett 2012); and planned hospital birth versus planned home birth (Olsen 2012).

- We only included non-clinical interventions specifically designed to reduce caesarean section rates (interventions not specifically designed to reduce caesarean section rates are not included, even if they may incidentally reduce caesarean section rates; these interventions have been proposed for further research in areas with high caesarean section rates).

- We expanded the scope of the review to include the following additional interventions.

* Opinion leaders: dissemination of information or advocacy with support or campaigns from local or international opinion leader (role models, leadership persons, public celebrities).

* Staffing models (e.g. different types of physician staffing models).

* Goal-setting for caesarean section rates (setting a specific predetermined goal for caesarean section rate).

* Policies that limit financial/legal liability in case of litigation of healthcare professionals or organisations.

* Strategies to change the organisational culture: strategies include various components of organisational culture (e.g. shared values, behaviours, norms, traditions, sense-making) which may shape and/or contribute to the overall environment of an organisation).

- We adopted a new system for classifying identified interventions drawing on updated EPOC taxonomy (Table 1; EPOC 2015). The new system also drew on the taxonomy drafted by the World Health Organization (WHO) expert panel on caesarean section guidelines.

- Types of outcome measures (primary outcomes amended to include only modes of delivery: caesarean section, spontaneous vaginal birth, instrumental vaginal birth).

- We implemented GRADE and created 'Summary of findings' tables.

- New authors: Innie Chen, Newton Opiyo, Ana Pilar Betran, Sameh Mortazhejri, Jennifer Petkovic, Tamara Rader, Sugandha Agarwal, Monica Taljaard, Sharlini Yogasingam.

\section{IN DEX TERMS}

\section{Medical Subject Headings (MeSH)}

*Prenatal Education; * Relaxation Therapy; Anxiety [therapy]; Cesarean Section [ ${ }^{\star}$ statistics \& numerical data]; Controlled Before-After Studies; Guideline Adherence; Interrupted Time Series Analysis; Parturition [psychology]; Randomized Controlled Trials as Topic; Referral and Consultation [statistics \& numerical data]; Unnecessary Procedures [ ${ }^{\star}$ statistics \& numerical data]; Vaginal Birth after Cesarean [statistics \& numerical data]

\section{MeSH check words}

Female; Humans; Pregnancy 